\author{
UNIVERSIDADE DE SÃO PAULO \\ FACULDADE DE FILOSOFIA, LETRAS E CIÊNCIAS HUMANAS \\ DEPARTAMENTO DE HISTÓRIA \\ PROGRAMA DE PÓS-GRADUAÇÃO EM HISTÓRIA SOCIAL
}

HENRIQUE RODRIGUES DE PAULA GOULART

\title{
Entre os Estados Unidos e o Atlântico Negro: o Black Power de Stokely Carmichael (1966-1971)
}

VERSÃO CORRIGIDA

SÃO PAULO 


\section{Entre os Estados Unidos e o Atlântico Negro: o Black Power de Stokely Carmichael (1966-1971)}

Dissertação apresentada ao Programa de PósGraduação em História Social da Faculdade de Filosofia, Letras e Ciências Humanas da Universidade de São Paulo para a obtenção do título de Mestre.

Orientadora: Profa. Dra. Mary Anne Junqueira

VERSÃO CORRIGIDA

SÃO PAULO 
Autorizo a reprodução e divulgação total ou parcial deste trabalho, por qualquer meio convencional ou eletrônico, para fins de estudo e pesquisa, desde que citada a fonte.

Catalogação na Publicação

Serviço de Biblioteca e Documentação

Faculdade de Filosofia, Letras e Ciências Humanas da Universidade de São Paulo

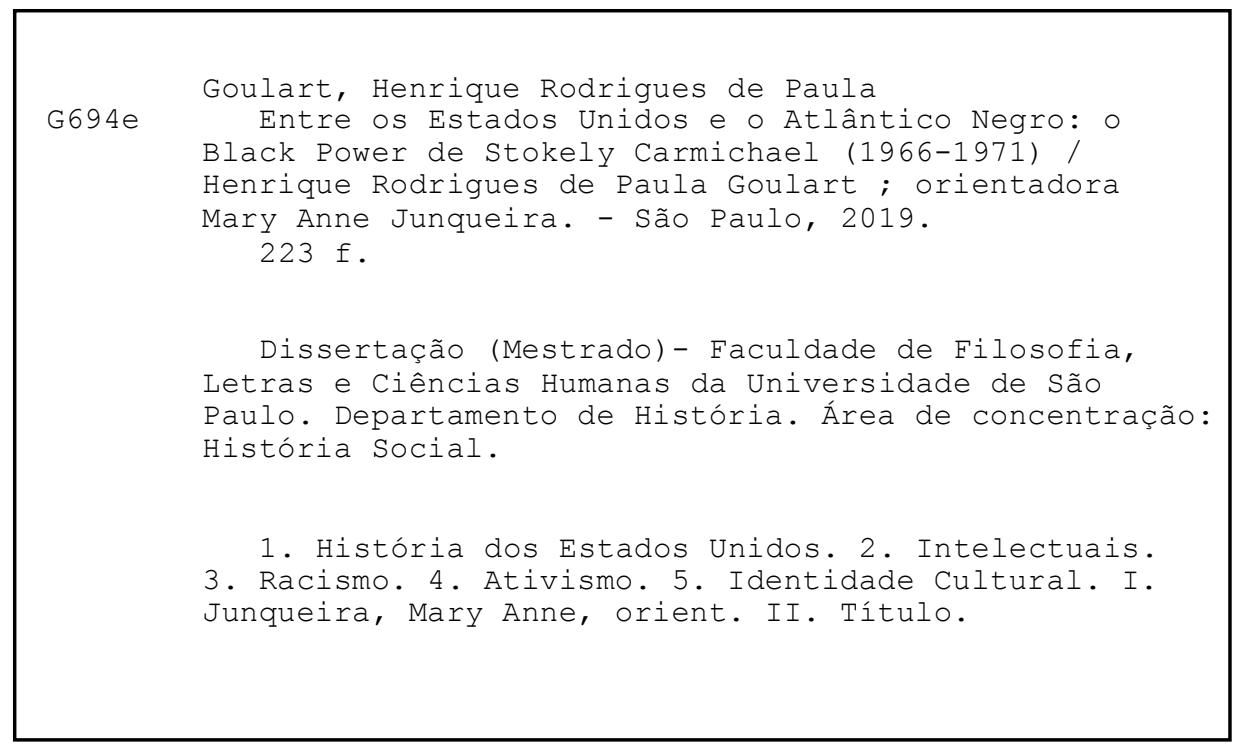




\section{ENTREGA DO EXEMPLAR CORRIGIDO DA DISSERTACC̃O/TESE Termo de Ciência e Concordância do (a) orientador (a)}

Nome do (a) aluno (a): Henrique Rodrigues de Paula Goulart

Data da defesa: 31 / 05 / 2019

Nome do Prof. (a) orientador (a): Profa. Dra. Mary Anne Junqueira

Nos termos da legislação vigente, declaro ESTAR CIENTE do conteúdo deste EXEMPLAR CORRIGIDO elaborado em atenção às sugestões dos membros da comissão Julgadora na sessão de defesa do trabalho, manifestando-me plenamente favorável ao seu encaminhamento e publicação no Portal Digital de Teses da USP.

São Paulo, 15 / 07 / 2019

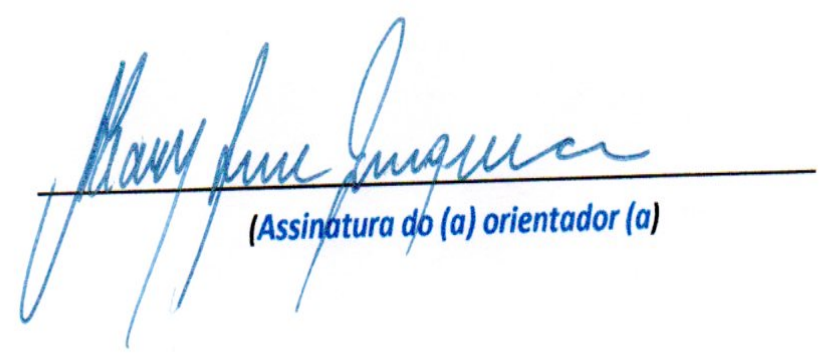


GOULART, Henrique Rodrigues de Paula. Entre os Estados Unidos e o Atlântico Negro: o Black Power de Stokely Carmichael (1966-1971). Dissertação apresentada ao Programa de PósGraduação em História Social da Faculdade de Filosofia, Letras e Ciências Humanas da Universidade de São Paulo para a obtenção do título de Mestre.

Aprovado em:

Banca examinadora

Prof.(a) Dr.(a) Instituição:

Julgamento: Assinatura:

Prof.(a) Dr.(a) Instituição:

Julgamento: Assinatura:

Prof.(a) Dr.(a) Instituição:

Julgamento: Assinatura: 


\section{AGRADECIMENTOS}

Agradeço a Fundação de Amparo à Pesquisa do Estado de São Paulo (FAPESP) e à Coordenação de Aperfeiçoamento de Pessoal de Nível Superior (CAPES) pela bolsa de Mestrado concedida entre abril de 2017 e março de 2019, no âmbito do convênio FAPESP/CAPES, por meio do processo $n^{0}$ 2016/25090-0, Fundação de Amparo à Pesquisa do Estado de São Paulo (FAPESP), que viabilizou minha dedicação integral a esta pesquisa.

À minha orientadora, Mary Anne Junqueira, por possibilitar, com muito diálogo construtivo, paciência e dedicação, o meu ingresso no vasto campo de pesquisa que é a História dos Estados Unidos. Professora, o seu comprometimento e cuidado com o trabalho de orientação foram fundamentais para a minha formação e crescimento intelectuais durante todo esse tempo de estudo. Sou muito grato!

Aos professores Robert Sean Purdy e Flávio Thales Ribeiro Francisco pelas contribuições contínuas e precisas ao trabalho desde a minha entrada na pós-graduação, passando pelo exame de qualificação, até a defesa da dissertação. É uma grande satisfação poder aprender com suas reflexões e posicionamentos acerca deste e tantos outros temas.

Sou eternamente grato aos meus pais, Fátima e Paulo, e à minha irmã, Luisa, pelo apoio e carinho incondicionais sem os quais esta caminhada - e tantas outras - não seria de forma alguma possível. À minha avó Wanda, à minha prima Duda e aos meus tios Júnior, Toninho e "Landinha". Ao Mel, pelas palavras sinceras e motivacionais. A todos vocês, o meu mais profundo agradecimento e admiração por tudo que representam para mim e para os demais à sua volta. Vô Rômulo, "saúde e paz”!

À Luisa Saldanha, companheira de todas as horas, boas ou más, que atravessaram minha experiência de pesquisa. Por tudo aquilo que nós dividimos nessa trajetória, pelas nossas conversas, nossos passeios, memórias e pela doce alegria de te reencontrar após longos períodos de ausência, muito obrigado! À Teca e às(aos) Saldanha Barcelos, com carinho.

Ao grande amigo Pedro Veras por vivenciar comigo, sempre com um comentário bem humorado e um abraço afetuoso, o entusiasmo e as incertezas que marcam a vida acadêmica. Serei sempre grato pelas muitas conversas, risadas e longos períodos de escuta, meu irmão! À querida Aline e à Florinha que chega nos trazendo muita alegria!

Ao Gui, "mofiote", amigo-irmão de uma vida. À Vanessa, pelo carinho de tantos anos.

Aos amigos que a Universidade de São Paulo tem me proporcionado. À querida amiga 
Maria Salete por me acolher em momentos de dificuldade e por me provar que existe sim amor e generosidade - em “SP”. Fia, não me esquecerei disso. À Paola, Nati Lins, Luiz e Filip pela receptividade carinhosa, pelos bons momentos partilhados. Vocês todas(os) fizeram eu me sentir em casa.

A todos os colegas de orientação e de trabalho no LEHA e no ENEUA. Em especial, agradeço ao Lucas e ao Michel, pela proximidade e parceria que construímos, trocas acadêmicas e bons papos que tivemos nestes últimos anos. Meus caros, vocês são parte essencial de tudo isso! Ao Emílio e à Gabriela, pela gentileza e disponibilidade em me ajudar hoje e quando ingressei na pós-graduação. A todos vocês, o meu carinhoso "muito obrigado" por tudo que agregam e representam!

Aos colegas e professores queridos da Universidade Federal de Minas Gerais, onde dei os primeiros passos no estudo da História durante a graduação. Após todo este tempo, carrego comigo nestas páginas suas muitas contribuições. É impossível querer nomear todos(as) sem incorrer em injustiças. No entanto, gostaria de mencionar os queridos Allysson Lima, Lu Marques, Bruno Corrêa, Bruno Morais e Felipe Malacco, bem como agradecer à Kátia Gerab Baggio e ao Daniel Rocha, professores amigos que abriram as portas para o meu ingresso no estudo da História dos Estados Unidos. Não poderia esquecer, também, do nosso grupo de amigas (e amigo) tão especial: Bárbara, Júlia, Bruna, Luisa, Tatá Lanna, Tatá Tanure, Nati e Clycia; vocês são fantásticas. Obrigado por toda a nossa trajetória juntos!

Ao Robson, pela escuta sempre atenciosa e solidária.

Ao amigo Henrique ("Bean”) Morávia, pela amizade de longa data.

I would also like to thank Professor Brenda Gayle Plummer for introducing me to the history of the Civil Rights and Black Power movements while I was an undergraduate exchange student at the University of Wisconsin-Madison in the fall of 2013. This dissertation also draws from the readings and discussions offered in Professor Plummer's class.

Aos amigos dos tempos escolares, que se mantém ao meu lado a despeito do pouco contato. Aos novos e queridos amigos do "ponto" e do "terraço" que me acolheram com tanto carinho.

Por fim, agradeço às tantas vozes que, nunca recuando perante o silenciamento, partilharam comigo um pouco das suas vivências, lutas e reflexões. A elas - e às outras que ainda virão - meu máximo respeito pela força e coragem. 
"Aqueles que professam favorecer a liberdade e, ainda assim, desaprovam a agitação, são homens que querem as colheitas sem arar o solo; eles querem chuva sem trovão e relâmpago. Eles querem o oceano sem o terrivel rugido de suas muitas águas. Esta luta pode ser moral ou pode ser fisica e pode ser moral e fisica, mas precisa ser uma luta. O poder não concede nada sem que haja uma demanda. Ele nunca concedeu e nunca concederá. Descubra exatamente a quê um povo silenciosamente se submeterá e você terá descoberto a medida exata da injustiça e do mal que lhes serão impostos, e estes continuarão até que sejam enfrentados com palavras ou golpes ou com ambas. Os limites dos tiranos são prescritos pela resistência daqueles a quem oprimem".

Frederick Douglass West Indian Emancipation Speech, 1857

"Agora, meus amigos, nos defrontamos com o fato de que o amanhã é hoje. Somos confrontados com a feroz urgência do agora. Nesse desdobramento da vida e da história, há algo de tarde demais. A procrastinação ainda é o ladrão do tempo. A vida muitas vezes nos deixa em pé desprotegidos, nus e abatidos por uma oportunidade perdida. A maré dos assuntos dos homens não permanece na cheia - ela se esvai. Podemos gritar desesperadamente pelo tempo para fazer uma pausa em sua passagem, mas o tempo é inflexivel a todos os apelos e segue em frente. Sobre os ossos branqueados e os resíduos dispersos de numerosas civilizações estão escritas as patéticas palavras 'tarde demais'. Existe um livro invisivel da vida que registra fielmente nossa vigilância ou nossa negligência. Omar Khayyam está certo: 'O dedo em movimento escreve e, tendo escrito, segue em frente",.

Martin Luther King Jr. Beyond Vietnam: a Time to Break Silence, 04 de abril de 1967 


\title{
RESUMO
}

Este trabalho analisa o pensamento e os projetos políticos de Stokely Carmichael, ativista e intelectual negro de origem caribenha engajado nos movimentos pelos Direitos Civis, Black Power e pan-africanista nos Estados Unidos e internacionalmente, entre os anos de 1966 e 1971. O objetivo é realizar uma leitura crítica das duas principais obras do ativista: o livro Black Power: The Politics of Liberation e a coletânea de discursos e artigos intitulada Stokely Speaks: From Black Power to Pan-Africanism publicadas, respectivamente, em 1967 e 1971. No decorrer dos anos, a trajetória transnacional do ativista indica mudanças importantes no que diz respeito à sua ação e às suas crenças. Portanto, acompanhamos através dos seus escritos não apenas suas proposições - o seu projeto político - como os fundamentos para essas transformações pessoais que informaram seu ativismo político. Nesse sentido, trata-se de analisar as distintas maneiras pelas quais as identidades nacional e negra foram expressas pelo militante.

Palavras-chave: História dos Estados Unidos, Intelectuais, Direitos Civis, Black Power, Identidades pós-modernas.

\begin{abstract}
This work analyzes Stokely Carmichael's thought and political projects between 1966 and 1971. Carmichael was an activist and black intellectual engaged in the Civil Rights, Black Power, and Pan-African movements in the United States and abroad. The goal is to engage in a critical reading of the two main works published by Carmichael: Black Power: The Politics of Liberation and a collection of his speeches and articles entitled Stokely Speaks: From Black Power to PanAfricanism published, respectively, in 1967 and 1971. In the course of the years, the activist's trajectory reveals important changes regarding his actions and his beliefs. Therefore, we followed in his writings not only his propositions - i.e., his political project - but also the reasons behind these personal transformations which impacted his political activism. In this sense, this work also discussed the various ways through which national and black identities were expressed by the militant.
\end{abstract}

Keywords: United States History, Civil Rights, Black Power, Intellectuals, Cultural identities. 


\section{LISTA DE ABREVIATURAS}

AAPRP - All-African People's Revolutionary Party

BUF - Black United Front

COFO - Council of Federated Organizations

CORE - Congress of Racial Equality

CPP - Convention People's Party

CPUSA - Communist Party USA

DRUM - Dodge Revolutionary Union Movement

IWW - Industrial Workers of the World

LCFO - Lowndes County Freedom Organization

MFDP - Mississippi Freedom Democratic Party

NAACP - National Association for the Advancement of Colored People

NAG - Nonviolent Action Group

NUL - National Urban League

RAM - Revolutionary Action Movement

SCLC - Southern Christian Leadership Conference

SDS - Students for a Democratic Society

SNCC - Student Nonviolent Coordinating Committee

WASP - White, Anglo-Saxon, Protestant 


\section{LISTA DE IMAGENS}

IMAGEM 1 - Bayard Rustin e Malcolm X na Howard University...........................................56

IMAGEM 2 - Stokely Carmichael e as Freedom Rides......................................................59

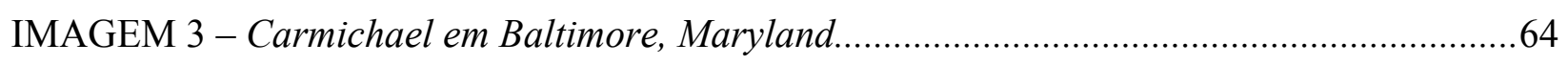

IMAGEM 4 - Fannie Lou Hamer e Bob Moses em Atlantic City.............................................70

IMAGEM 5 - Carmichael, Hamer e Ella Baker em comício do MFDP....................................70

IMAGEM 6 - Carmichael em Lowndes County, Alabama ........................................................79

IMAGEM 7 - Ativistas do SNCC engajados no LCFO, Alabama ..............................................81

IMAGEM 8 - Carmichael, McKissick e King na "Marcha Contra o Medo"...............................88

IMAGEM 9 - O grito de “Black Power!” em Greenwood, Mississippi...................................89

IMAGEM 10 - Carmichael discursa contra a Guerra do Vietnã em Nova York......................170

IMAGEM 11 - Kwame Nkrumah, lider da independência de Gana........................................ 191

IMAGEM 12 - Carmichael a favor da libertação do pantera negra Huey Newton...................194

IMAGEM 13 - Carmichael como militante pan-africanista da AAPRP...................................200 


\section{SUMÁRIO}

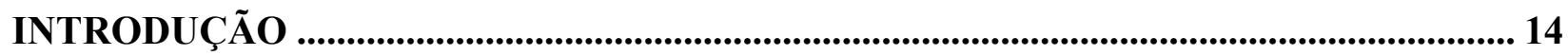

CAPÍTULO 1 - FORMAÇÃo E INÍCIO DO ATIVISMO POLÍTICO DE STOKELY

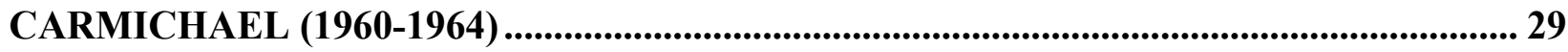

1.1. Do Caribe aos Estados Unidos: Stokely Carmichael, um "sobreVivente da

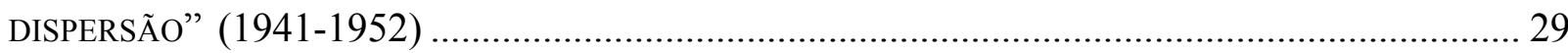

1.2. A Nova YoRK DE CARMiCHAEL: ESPAÇOS DE FORMAÇão POLÍTICA E INTELECTUAL (19521960) 32

1.2.1. Harlem: confluência de tradições políticas negras ..................................................... 34

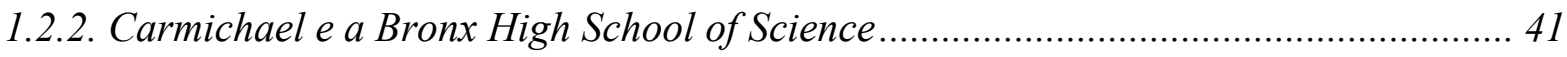

1.3. Stokely Carmichael: ativista do Movimento Pelos Direitos Civis .......................... 43

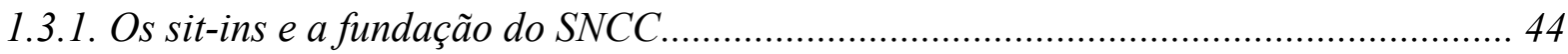

1.3.2. Howard University: vida intelectual de Carmichael no campus................................ 48

1.3.3. Carmichael e o Nonviolent Action Group: primeiros passos no ativismo ................... 51

1.4. A "LINHA De FRENTE" dos Direitos Civis: Carmichael nas CaMPanhas do SNCC

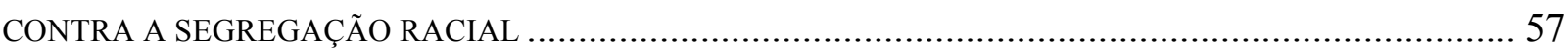

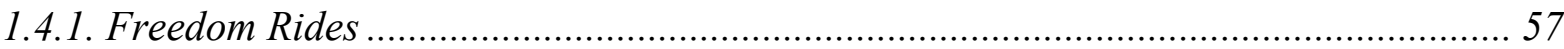

1.4.2. Campanhas pelo registro eleitoral de afro-americanos no Mississippi...................... 59

1.4.3. Engajamento político em Washington e Maryland................................................... 62

1.5. A desilusão de Carmichael com o Governo Federal e o Partido Democrata (1964)

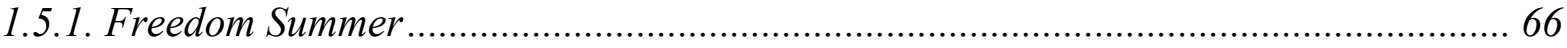

1.5.2. Atlantic City e a ruptura com o establishment Democrata......................................... 69

CAPÍTULO 2 - A RADICALIZAÇÃO POLÍTICA DE STOKELY CARMICHAEL E A ASCENSÃO DO MOVIMENTO BLACK POWER NOS ESTADOS UNIDOS (1965-1966)

2.1. CARMICHAEL, O SNCC E A BUSCA POR NOVOS CAMINHOS PARA O ATIVISMO NEGRO............ 73

2.2. DE LIDERANÇA REGIONAL A NACIONAL: STOKELY CARMICHAEl E A VIRADA PARA A

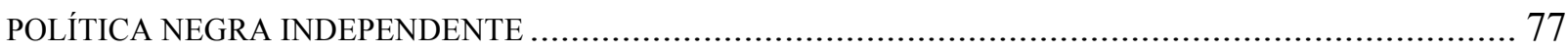

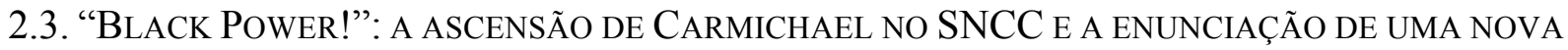

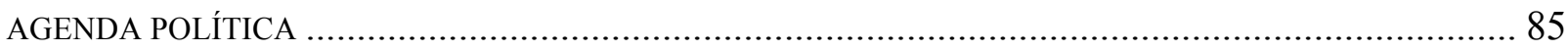

2.4. A REAÇÃO NACIONAL AO BLACK PoWER: IMPRENSA E MOVIMENTO NEGRO ……………..... 90

CAPÍTULO 3 - POR UMA IDENTIDADE E POLÍTICA NEGRAS NOS ESTADOS UNIDOS: O PROJETO POLÍTICO DE STOKELY CARMICHAEL NO LIVRO "BLACK POWER: THE POLITICS OF LIBERATION" (1966-1967) ...................................................... 96

3.1. O eSPeCtro Político e Cultural do Movimento Black Power ..................................... 97 


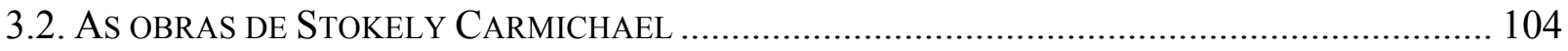

3.2.1. O livro Black Power: uma parceria entre intelectuais engajados .......................... 106

3.3. O DiAGNÓSTICO DAS RELAÇÕES RACIAIS NORTE-AMERICANAS NO LIVRO BLACK POWER .. 109

3.3.1. "Governo indireto": a política do racismo institucional ........................................ 112

3.3.2. Exploração econômica: a "infraestrutura" colonial ............................................. 117

3.3.3. "Colônias internas": os guetos e a alienação psicológica do negro ......................... 120

3.4. O ATAQUe AO AMERICAN DREAM E A RUPTURA COM OS Direitos CiVIS NA OBRA DE

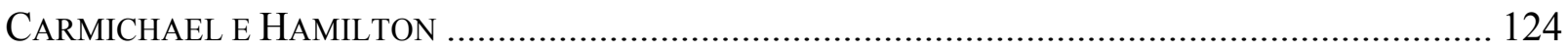

3.4.1. Os impedimentos à integração do negro à sociedade norte-americana ................... 128

3.4.2. "Cerrar as fileiras": a oposição do Black Power às alianças políticas interraciais 131

3.4.3. Black Power: a não-violência dos Direitos Civis em xeque................................... 137

3.5. LIBERTAR A CONSCIÊNCIA E O GUETO: A AGENDA POLÍTICO-IDENTITÁRIA DE STOKELY

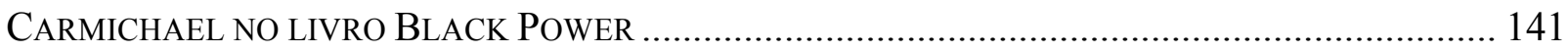

3.6. A REPERCUSSÃO DO LIVRO ………………………………................................... 148

CAPÍTULO 4 - A CONFORMAÇÃO DE UMA POLÍTICA E IDENTIDADE NEGRAS TRANSNACIONAIS NOS DISCURSOS E ARTIGOS DE STOKELY CARMICHAEL

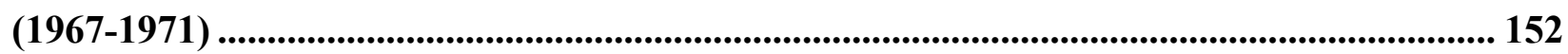

4.1. Terceiro-Mundismo, Guerra Fria e a AgEnda transnacional de Stokely

CARMICHAEL PARA O MOVIMENTO BLACK POWER ................................................................. 153

4.1.1. "Hell no, we won't go!”: Guerra do Vietnã, movimento antibelicista e o antiimperialismo de Stokely Carmichael ......................................................................... 159

4.1.2. “Terceiro Mundo, nosso mundo": solidariedades revolucionárias, anticapitalismo e antirracismo em Londres e Havana ....................................................................... 171

4.1.3. Argélia e Guiné: “cooperação afro-árabe” e primeiras sociabilidades pan-

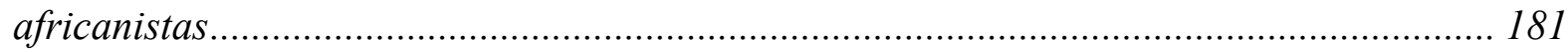

4.2. "NÓS SOMOS UM MESMO POVO": IDENTIDADE DIASPÓRICA E O PROJETO PAN-AFRICANISTA DE

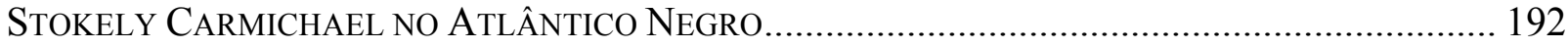

4.2.1. Carmichael, a AAPRP e o caminho para a revolução pan-africana ........................ 198

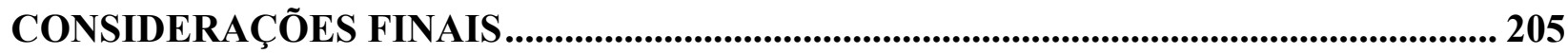

REFERÊNCIAS BIBLIOGRÁFICAS GERAIS .................................................................. 212 


\section{INTRODUÇÃO}

Esta dissertação de Mestrado analisa os projetos político-identitários de Stokely Carmichael (1941-1998), ativista e intelectual negro nascido no país caribenho de Trinidad e Tobago que se destacou nos Estados Unidos por sua atuação política durante os movimentos pelos Direitos Civis e Black Power da década de 1960. Nesse período, Carmichael foi um ativista prolífico tanto em propor novas ações para a militância afro-americana da sua geração quanto na diversidade das arenas políticas locais, nacionais e internacionais às quais se apresentou. Assim, embora Stokely tenha se tornado publicamente reconhecido pelo combate ao racismo entre os norte-americanos, ele também se engajou com as múltiplas agendas anti-imperialistas, anticapitalistas e anticoloniais que mobilizavam as esquerdas norte-americanas e internacionais da época.

Transformando-se constantemente, a trajetória de Carmichael nada tem de linear: durante sua formação universitária, atuou como um ativista do SNCC - Student Nonviolent Coordinating Committee, grupo engajado no front sulista do Movimento pelos Direitos Civis que mobilizou estudantes e lideranças negras reformistas de todo o país no início dos anos de 1960 contra a segregação racial institucionalizada nas leis e nas práticas da região. Em meados da década,

Stokely foi um dos propositores e referência central do Black Power, movimento que "escandalizou" boa parte dos norte-americanos ao propor a autodeterminação política e o orgulho racial/identitário entre os afro-americanos como forma de luta radical contra o racismo sistêmico no país. Ao final dos anos 1960, Carmichael vivenciou, ainda, nova inflexão em suas perspectivas ao ingressar no complexo cenário das descolonizações e movimentos de libertação nacional africanos, asiáticos e latino-americanos do então chamado "Terceiro Mundo". Cruzando espaços e países profundamente atravessados pelas disputas por influência política entre (e intra) os blocos capitalista e socialista da Guerra Fria, o ativista rompeu com a política doméstica norteamericana e reinventou-se, então, como um revolucionário pan-africanista sediado na Guiné, antiga colônia francesa da África Ocidental.

Não obstante tenha se notabilizado nos Estados Unidos por sua marcante trajetória de ativismo político durante os anos sessenta, é necessário ressaltar que Stokely foi, também, um intelectual diretamente envolvido com o intenso debate público que tomou conta do país e do campo progressista da época sobretudo após a ascensão do Movimento Black Power à cena 
pública nacional em 1966. Assumindo uma posição de destaque entre a militância afroamericana, Carmichael discutiu intensamente suas propostas para o movimento negro através de escritos e discursos direcionados a audiências norte-americanas e internacionais bastante diversas.

Naquele contexto efervescente, Stokely publicou suas principais obras, o influente livro Black Power: The Politics of Liberation (1967) e a coletânea de artigos e discursos Stokely Speaks: From Black Power to Pan-Africanism (1971), nas quais seu engajamento e suas reflexões combinaram-se para (re)definir os horizontes do ativista acerca da luta política negra dentro e fora dos Estados Unidos. ${ }^{1}$ Portanto, partindo dessa documentação e, também, de outros textos de sua autoria como os artigos El Tercer Mundo, Nuestro Mundo e Pan-Africanism - Land and Power, este trabalho buscou compreender a atividade política - isto é, os projetos políticos e intelectual de Carmichael entre os anos de 1966 e 1971. Por meio deste recorte contemplamos os principais processos que marcaram a trajetória de Stokely desde sua ruptura com o Movimento pelos Direitos Civis, passando pela proposição e difusão de um programa político para o movimento Black Power, até a adesão e consolidação da sua agenda pan-africanista. ${ }^{2}$

Ao analisarmos os projetos políticos concebidos pelo militante nesses marcos temporais os quais avançamos ou recuamos a fim de melhor esclarecer o campo mais amplo de atuação e reflexão do ativista -, entendemos Carmichael como representante de uma militância afroamericana que, em meados da década de 1960, passara a recusar a luta pela integração do negro à sociedade norte-americana (branca) em favor de agendas político-identitárias negras radicais e cada vez mais transnacionais. Distanciando-se do reformismo de Martin Luther King que se dedicava à inclusão dos negros nos marcos da cidadania norte-americana, Carmichael e o Black Power voltaram-se, então, às reivindicações separatistas de Malcolm X por autodeterminação e poder político para os afro-americanos e suas comunidades por "quaisquer meios necessários".

No entanto, ao final da década, tais perspectivas assumiram, ainda, novos matizes e contornos revolucionários identificados às lutas "terceiro-mundistas" do período e aos processos de descolonização no continente africano. Ou seja, nas formulações do ativista, para além de lidar com as dinâmicas da exclusão e marginalização racial nos Estados Unidos, o Black Power

\footnotetext{
${ }^{1}$ CARMICHAEL, Stokely; HAMILTON, Charles V. Black Power: The Politics of Liberation. 2. ed. New York: Vintage Books, 1992; CARMICHAEL, Stokely. Stokely Speaks: From Black Power to PanAfricanism. 2. ed. Lawrence Hill Books, 2007.

${ }^{2}$ CARMICHAEL, Stokely. El Tercer Mundo, Nuestro Mundo. Tricontinental, v. 1., n. 1, jul. - ago. 1967, p. 15-21; Idem. Pan-Africanism - Land and power. Black Scholar, v. 27, n. 3/4, fall/winter 1997, p. 58-64.
} 
construía-se, também, transnacionalmente, como uma proposta pela libertação negra em todo o Atlântico. Assim, estabelecendo-se em Conacri, capital da Guiné, sob os auspícios de Kwame Nkrumah, líder da independência de Gana, e Ahmed Sékou Touré, presidente guineense, Stokely passou a promover uma agenda revolucionária e socialista particular como o "caminho" privilegiado para a libertação negra tanto na África quanto na diáspora.

Em suma, queremos com isso reiterar ao leitor que o percurso do ativista no decorrer dos anos sessenta foi marcado por mudanças significativas tanto em seu posicionamento político quanto em suas crenças pessoais. Por essa razão, a análise da documentação não se limitou apenas às proposições de Stokely Carmichael para a luta antirracista do período, mas debruçouse, também, sobre os aspectos subjetivos, identitários, imbricados na atuação política do ativista. Isto é, esta pesquisa investigou as maneiras pelas quais Carmichael expressou e articulou as identidades negra e nacional em sua produção intelectual, tendo em vista que, à maneira do seu projeto político, as perspectivas identitárias do militante também passaram por modificações substanciais no decorrer da década de 1960.

A esse respeito, os escritos de Carmichael desvelam três fases distintas: primeiramente, no contexto dos Direitos Civis, o ativista vinculou-se a uma perspectiva nacional segundo a qual os negros deveriam ser integrados à cultura, à identidade e comunidade nacionais norteamericanas mais amplas. Em meados dos anos 1960 em diante, durante o Movimento Black Power, isso mudou de figura. Para ele, tratava-se, então, de projetar uma identidade negra "nacional" assertiva e antagônica à norte-americana (branca) como ponto de partida da insurgência pretendida pelo Black Power contra os valores, a cultura e as instituições racistas vigentes nos Estados Unidos. Rejeitando, então, a vinculação dos negros a uma "América Branca" que se mostrava hostil e excludente, Carmichael e muitos ativistas e intelectuais de sua geração voltaram-se para fora do país em busca de referências outras para suas filiações identitárias. Como consequência, aproximando-se do "terceiro-mundismo" em voga no período e do movimento pan-africanista, Stokely reinventou-se uma vez mais, passando a mobilizar uma identidade negra transnacional e diaspórica.

\section{A bibliografia sobre os movimentos pelos Direitos Civis e Black Power}

Discutir a atuação e o pensamento de Stokely Carmichael implica mergulharmos em numerosas disputas que tensionavam o ambiente político dos Estados Unidos na década de 1960 
cujas reverberações se fizeram sentir, também, na historiografia que trata do tema. A produção bibliográfica sobre os movimentos pelos Direitos Civis e Black Power é muito extensa e passa por embates políticos e de memória relevantes aos quais o historiador brasileiro deve manter cuidado e atenção. Por exemplo, há disputas pelas memórias dos líderes do movimento negro que alcançaram o âmbito nacional, especialmente aqueles das décadas 1950 e 1960, como Martin Luther King e Malcolm X. Há também discussões contundentes que passam pela vitimização do negro na historiografia, além daquelas que atribuem o sucesso dos Direitos Civis mais às mobilizações locais do que às nacionais. Há ainda reivindicações por parte das mulheres negras acerca do seu papel tanto nos Direitos Civis quanto no Black Power, bem como polêmicas acerca dos limites temporais, dos legados contemporâneos destes dois movimentos e das suas relações com as esquerdas brancas e universitárias norte-americanas. Atentando à multiplicidade das questões que compõem esse universo de pesquisa, apresentaremos a seguir breve discussão historiográfica do tema, apontando alguns dos títulos com os quais dialogamos neste trabalho.

Inicialmente, nas décadas de 1960 e 1970, os trabalhos acerca do Movimento pelos Direitos Civis dedicaram-se majoritariamente à constituição de imagens respeitáveis da militância por meio de biografias e histórias políticas tradicionais das lideranças e organizações do ativismo negro. Em geral, privilegiando o escopo temporal da chamada "fase clássica" do Movimento (1954-1964/1965), tal produção concebia a luta dos Direitos Civis como um processo desenvolvido majoritariamente no Sul do país por uma coalizão entre lideranças masculinas e/ou religiosas e forças reformistas do Partido Democrata cujo objetivo era conquistar direitos políticos aos negros norte-americanos. Conformara-se, então, conforme aponta a historiadora Jacquelyn Dowd Hall, uma narrativa historiográfica “dominante” debruçada sobre os "episódioschave" e os momento "triunfais" do movimento que atribuía a Martin Luther King o

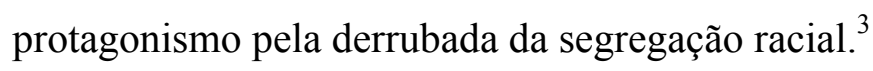

Muitos dos pesquisadores, biógrafos e jornalistas integrantes dessa primeira geração participaram diretamente da vida política do período, engajando-se nas organizações que à época lutavam contra o racismo. Dentre estes, o ativista do SNCC e historiador Howard Zinn atualmente um conhecido autor da "história vista de baixo" (history from below) - publicou, em 1964, o livro SNCC: The New Abolitionists, um estudo pioneiro sobre o grupo no qual definiu os

\footnotetext{
${ }^{3}$ HALL, Jacquelyn D. The Long Civil Rights Movement and The Political Uses of the Past. The Journal of American History, v. 91, n. 04, mar. 2005, p. 1233-1235.
} 
membros da organização como "novos abolicionistas", "agitadores" que compreendiam a prática do dissenso político como elemento central à vida democrática norte-americana. É deste período, também, o surgimento de uma forte produção memorialística cujo expoente mais notável foi, certamente, The Autobiography of Malcolm X, best-seller editado e publicado pelo jornalista Alex Haley após o assassinato de X em $1965 .^{4}$

Parte dos trabalhos das décadas de 1980 e 1990 continuaram pautados por esse enfoque "biográfico", mas lançando, então, um olhar renovado aos grupos e redes de ativistas que encampavam a luta por Direitos Civis nacional e localmente. Exemplo disso é o importante livro In Struggle: SNCC and the Black Awakening of the 1960s (1981) no qual o historiador Clayborne Carson discute a efervescência intelectual e radicalização do SNCC, grupo através do qual Stokely Carmichael engajou-se no movimento negro durante a maior parte dos anos 1960. Analisando a trajetória e os projetos de organização política comunitária que mobilizavam a militância do grupo país afora, Carson propõe entender a lutas negras da década não como iniciativas dirigidas exclusivamente por líderes como Martin Luther King e Malcolm X, mas "como um movimento de massas que produziu seus próprios líderes e ideias". 5

Naquele momento, a historiografia do tema como um todo foi atravessada por importantes modificações trazidas por influência da história social. Ao questionarem a ênfase dada às lideranças e organizações nacionais dos Direitos Civis, pesquisadores dos anos oitenta e noventa passaram a se dedicar a estudos de escopo local/regional. Com isso, visavam principalmente retirar o foco excessivo atribuído aos ícones dos anos 1950 e 1960, deslocando-o para os “de baixo", homens e mulheres "comuns" cujo trabalho muitas vezes anônimo dava sustentação local aos objetivos nacionais do movimento. Dentre esses trabalhos, I've Got The Light of Freedom. The Organizing Tradition and the Mississippi Freedom Struggle, do historiador Charles M. Payne, mostrou como, em princípio dos anos 1960, o avanço do movimento negro no estado do Mississippi - um dos palcos centrais da luta antirracista no qual Stokely Carmichael se engajou foi devedor de uma longa tradição de organizações comunitárias que remontava à atuação de gerações anteriores de ativistas locais (com destaque às mulheres negras) dedicados(as) à

\footnotetext{
${ }^{4}$ ZINN, Howard. SNCC: The New Abolitionists. Edição Kindle, 2002, p. 7-8; EAGLES, Charles W. Toward New Histories of the Civil Rights Era. The Journal of Southern History, v. 66, nov. 2000, p. 819820; X, Malcolm; HALEY, Alex. The Autobiography of Malcolm X. As told to Alex Haley. New York: Ballantine Books, 2015.

${ }^{5}$ CARSON, Clayborne. In Struggle. SNCC and the Black Awakening of the 1960s. Harvard University Press, 1981, p. 4.
} 
afirmação e autonomia das comunidades rurais negras ali presentes. ${ }^{6}$

Por sua vez, ao passo que transformava-se por influência da história social, a abordagem "tradicional" ou "clássica" foi impactada, também, pela publicação das primeiras sínteses históricas gerais que se propunham a abranger a luta dos negros por Direitos Civis e, em alguns casos, debater a periodização do Movimento para além de suas figuras-chave. Entre elas, The Struggle for Black Equality (1981), de Harvard Sitkoff, e Race, Reform, and Rebellion: The Second Reconstruction and Beyond in Black America (1984), de Manning Marable, situam as lutas negras por direitos políticos a partir do pós Segunda Guerra Mundial - no caso de Marable cujas raízes mais profundas remetiam à emancipação da escravidão consolidada com o final da Guerra Civil em 1865 - no caso de Sitkoff. ${ }^{7}$

De maneira geral, tais estudos contribuíram para que, nos anos 2000, as análises historiográficas expandissem significativamente os marcos da fase clássica (1954-1965) com o intuito de situar o ativismo negro dos anos 1960 em meio às redes, processos e tradições políticas que marcaram a história contemporânea dos Estados Unidos. Em American Crucible: Race and Nation in the Twentieth Century (2002), por exemplo, o historiador Gary Gerstle inseriu os Movimentos pelos Direitos Civis e Black Power nas disputas mais amplas entre nacionalismo cívico e racial, ideários políticos que, durante todo o século XX, articularam-se em projetos de sociedade ora mais inclusivos ora deliberadamente excludentes. Ao retomar experiências de luta anteriormente deixadas em segundo plano, historiadores reiteravam que o movimento negro precedia aos anos de 1950 e às figuras de Martin Luther King Jr e Malcolm X. Dessa forma, buscavam relacionar as lutas antirracistas da primeira metade do século XX às pautas e agitações introduzidas pelos movimentos dos Direitos Civis e Black Power nas décadas subsequentes. ${ }^{8}$

Enquanto isso, o surgimento e difusão do radicalismo do Movimento Black Power nas grandes cidades norte-americanas tornou-se objeto de uma produção historiográfica consistente iniciada a partir da década de 1990. A princípio culpabilizado por ter supostamente “descaracterizado" e favorecido a "decadência" do reformismo negro da década de 1960, o Black

\footnotetext{
${ }^{6}$ PAYNE, Charles M. I've Got The Light of Freedom. The Organizing Tradition and the Mississippi Freedom Struggle. 2. ed. Berkeley and Los Angeles: The University of California Press, 2007.

${ }^{7}$ SITKOFF, Harvard. The Struggle For Black Equality, 1954-1992. New York: Hill and Wang, 1993; MARABLE, Manning. Race, Reform, and Rebellion: The Second Reconstruction and Beyond in Black America, 1945-2006. 3. ed. Jackson: University Press of Mississippi, 2007.

${ }^{8}$ GERSTLE, Gary. American Crucible: Race and Nation in the Twentieth Century. Princeton and Oxford: Princeton University Press, 2002. Sobre o debate recente em torno da periodização do Movimento pelos Direitos Civis, cf. HALL, Jacquelyn Dowd. op. cit., p. 1245-1248.
} 
Power passou a ser considerado um importante processo histórico que para alguns suplantou e para outros tangenciou e até coexistiu com os Direitos Civis.

Uma obra-chave desse período é New Day in Babylon: The Black Power Movement and American Culture, 1965-1975, do historiador William L. Van Deburg (1992). Para Van Deburg, o Black Power constituiu um amplo e maleável movimento cujos impactos e legados históricos mais profundos residiam sobretudo nos âmbitos da cultura, consciência e das identidades negra e norte-americana. Atentando ao caráter multifacetado do movimento, suas distintas correntes, manifestações políticas, intelectuais, artísticas e estéticas, a obra é uma síntese histórica pioneira e abrangente sobre o tema. Por essa razão, New Day in Babylon é uma referência central para compreender o contexto político, intelectual e cultural negro pelo qual circulou Stokely Carmichael bem como as apropriações que dele realizou em seus escritos. ${ }^{9}$

Ainda mais recentemente, historiadores do Black Power e dos Direitos Civis têm destacado as continuidades entre ambos os movimentos, enfatizando que eles travaram fortes diálogos e compartilharam raízes históricas mais profundas. Dentre eles, os trabalhos de Joseph e Jeffrey Ogbar são referências importantes, em especial Waiting 'Til the Midnight Hour: A Narrative History of Black Power in America e Black Power: Radical Politics and African American Identity. ${ }^{10}$ Seguindo um viés mais narrativo, Joseph e Ogbar concebem o movimento Black Power como parte de um processo histórico mais amplo que remetia, mais imediatamente, ao radicalismo negro norte-americano do pós-Segunda Guerra Mundial, mas cujas origens recuavam às tradições políticas seculares como o nacionalismo negro e o pan-africanismo mobilizadas pelos negros em meio à Grande Depressão. No entanto, divergindo das abordagens "tradicionais" que associavam a "decadência" do ativismo negro e estudantil dos anos 1960 à radicalização trazida pelo Black Power, esses historiadores defendem que o movimento avançou sobre a década de 1970, legando importantes mobilizações e agendas políticas negras feminismo negro, pan-africanismo, marxismo e sindicalismo negros, dentre outros - à contemporaneidade. $^{11}$

\footnotetext{
${ }^{9}$ VAN DEBURG, William L. New Day in Babylon: The Black Power Movement and American Culture. Chicago: The University of Chicago Press, 1993.

${ }^{10}$ JOSEPH, Peniel E. Waiting 'Til the Midnight Hour. A Narrative History of Black Power. Edição Kindle. New York: Holt, 2007 e OGBAR, Jeffrey O.G. Black Power: Radical Politics and African American Identity. Baltimore: The John Hopkins University Press, 2004.

${ }^{11}$ JOSEPH, Peniel E. Introduction. In:___. (org.). The Black Power Movement. Rethinking the Civil Rights-Black Power Era. New York: Routledge, 2006, p. 4-11 e JOSEPH, Peniel E. Historians and the
} 
$\mathrm{Na}$ esteira dessas perspectivas, trabalhos atuais têm buscado reabilitar a militância do Black Power - e, sobretudo, do Partido dos Panteras Negras, a organização negra radical de maior expressão no período - das imagens de violência e criminalidade imputadas pela mídia e por parte dos relatos iniciais. Dentre essa historiografia, destaco a coletânea de artigos The Black Panther Party Reconsidered organizada por Charles E. Jones e, principalmente, o livro Black Against Empire: The History and Politics of the Black Panther Party, de Joshua Bloom e Waldo E. Martin. ${ }^{12}$

Nesses livros, os autores analisam a dinâmica organizacional dos Panteras Negras, suas contribuições intelectuais e ideológicas ao ativismo negro bem como debatem as razões para o declínio do grupo em meados da década de 1970. De maneira geral, portanto, o objetivo dos livros consiste em "desmistificar" a imagem construída em torno do grupo, privilegiando, especialmente no caso de Bloom e Martin, a discussão daquilo que constituía sua "política", isto é, as práticas, ideias, repertórios e ações disruptivas empregadas que destacavam os Panteras em meio aos grupos e movimentos dos Direitos Civis, Black Power e da Nova Esquerda estudantil branca. Por essa razão, Black Against Empire constitui uma referência indispensável àqueles que buscam compreender o complexo e multifacetado espaço político norte-americano dos anos 1960 dentro do qual atuou a geração de Stokely Carmichael.

Aqui, as obras do historiador brasileiro Rodrigo Farias de Sousa e do norte-americano Max Elbaum também oferecem contribuições importantes à discussão das múltiplas agendas e questões que informaram Carmichael e a juventude norte-americana engajada dos anos 1960. Trabalho pioneiro na historiografia nacional, A Nova Esquerda Americana analisa a transição do ativismo estudantil branco de uma perspectiva política essencialmente reformista e ancorada nos valores norte-americanos para uma abordagem revolucionária disposta a derrubar o "sistema americano" através do uso da violência. Focando na SDS - Students for a Democratic Society, a mais expressiva organização estudantil da Nova Esquerda, Rodrigo Farias mostra como esta militância universitária e branca ora aproximou-se e ora distanciou-se de grupos do movimento negro como o SNCC e os Panteras Negra que informaram sua atuação. Por sua vez, em Revolution in the Air, Elbaum discute como, a partir de 1968, as esquerdas norte-americanas

Black Power Movement. OAH Magazine of History, v. 22, n. 03, p. 8-15, jul. 2008.

12 JONES, Charles E. (org.). The Black Panther Party Reconsidered. Edição Kindle. Black Classic Press, 2013 e BLOOM, Joshua; MARTIN JR., Waldo E. Black against Empire: the history and politics of the Black Panther Party. Oakland: University of California Press, 2016. 
voltaram-se a uma perspectiva de transformação social profundamente identificada ao engajamento radical de grupos marginalizados nos Estados Unidos - negros, hispânicos e asiáticos - e às lutas revolucionárias do movimento comunista internacional contra o imperialismo, capitalismo e racismo no "Terceiro Mundo". ${ }^{3}$

Por último, assim como observamos no caso dos Direitos Civis e da Nova Esquerda, cabe destacarmos que a disputa pela memória histórica de grupos e lideranças também atravessa os trabalhos dedicados ao Movimento Black Power. As publicações de biografias recentes sobre ícones da militância negra como Stokely Carmichael e Malcolm X são alguns exemplos importantes disso. ${ }^{14}$ Nestas, à semelhança do proposto por Jones, Bloom e Martin, os autores buscam situar e avaliar o papel desempenhado por estes sujeitos dentro da história do ativismo negro norte-americano do pós-Guerra. Entretanto, a despeito dessas publicações, a historiografia do Black Power permanece carente de análises voltadas à reflexão desses ativistas enquanto intelectuais.

Atentando a essa lacuna na historiografia do tema, o estudo que propomos é de um historiador brasileiro interessado em História dos Estados Unidos e nos movimentos de luta dos negros norte-americanos na segunda metade do século XX. Ainda que o nome de Stokely Carmichael figure em grande parte dos livros sobre Direitos Civis e Black Power, a atuação e produção do ativista são amplamente desconhecidas pela academia e pelo público brasileiros. Mesmo na historiografia norte-americana, os escritos de sua autoria não foram contemplados com uma leitura crítica que busque analisar seu pensamento, propostas, sociabilidades políticas e intelectuais de maneira mais detida já que parte dessa bibliografia dedica-se, ainda, a discutir (e disputar) os fatos, os símbolos e a(s) memória(s) dos movimentos. Tendo isso em mente, o nosso objetivo é oferecer uma contribuição à historiografia do tema abordando Stokely Carmichael como um ativista e intelectual negro engajado nas múltiplas e multifacetadas disputas políticas que, na década de 1960, galvanizaram o campo progressista nos - e também fora dos - Estados Unidos.

\footnotetext{
${ }^{13}$ SOUSA, Rodrigo Farias de. A Nova Esquerda Americana: De Port Huron aos Weathermen (19601969). Rio de Janeiro: Editora FGV, 2009 e ELBAUM, Max. Revolution in the air. Sixties radicals turn to Lenin, Mao and Che. 2a ed. London \& New York: Verso, 2018.

${ }^{14}$ Especificamente, JOSEPH, Peniel E. Stokely: A Life. New York: Basic Civitas, 2014 e MARABLE, Manning. Malcolm X: Uma Vida de Reinvenções. Companhia das Letras, 2013.
} 


\section{Aporte teórico-metodológico}

Em primeiro lugar, o presente trabalho inscreve-se no âmbito da Nova História Política, filiando-se, em especial, à área de História dos Intelectuais. As contribuições dadas por JeanFrançois Sirinelli a esse respeito são, portanto, referências importantes para esta pesquisa e merecem destaque. Para o autor, o estudo histórico dos intelectuais deve buscar compreender a atuação destes sujeitos dentro de um campo político específico. Sirinelli defende a necessidade de identificar pontos como as trajetórias e itinerários desses sujeitos, sua vinculação a uma determinada geração pautada por um "acontecimento fundador" e uma memória coletiva em comum e a sua inserção em redes de sociabilidade intelectual, afetiva e ideológica compartilhadas entre seus "pares". ${ }^{15}$

Em suma, o intelectual deve ser compreendido, portanto, à luz de seu tempo, espaço e círculos frequentados. No recorte aqui estipulado, isso implicou perscrutar as relações entre as perspectivas concebidas ou veiculadas por Stokely Carmichael e as culturas políticas mais amplas que pautavam o movimento negro em particular e, de maneira geral, as esquerdas norteamericanas e internacionais dos anos sessenta.

Por sua vez, ao avaliarmos a inserção política de Carmichael na década de 1960 foi indispensável considerarmos, também, a natureza essencialmente pública e "comunicativa" da atividade intelectual do ativista. Em relação a esse aspecto, as reflexões desenvolvidas pelo crítico literário e ativista da causa palestina Edward Said foram de grande relevância para este trabalho. Segundo Said, o papel social do intelectual é definido pelo seu engajamento em um debate público no qual cabe a ele representar e mediar - traduzir, tornar acessível - determinados pontos de vista para uma audiência. Traçando um paralelo com a condição do exílio, o autor caracteriza o intelectual como um "expatriado", um outsider em sua própria nação e cultura que afirma sua independência através da análise e do pensamento críticos exercidos à margem dos (e contra os) poderes sociais constituídos. Trata-se, enfim, de um sujeito que se propõe a representar uma "causa" e a "falar a verdade ao poder", o que, no caso aqui estudado, evidenciou-se no compromisso de Carmichael - e da militância negra a qual ele se vinculava - com o debate, a denúncia e o combate contundentes contra o racismo (principalmente) nos Estados Unidos. ${ }^{16}$

\footnotetext{
${ }^{15}$ SIRINELLI, Jean-François. Os intelectuais. In: RÉMOND, René (org.). Por Uma História Política. Editora FGV, 2003.

${ }^{16}$ SAID, Edward W. Representações do Intelectual: as Conferências de Reith de 1993. Companhia das
} 
Um outro ponto a ser destacado diz respeito ao papel que o fluxo transnacional de ideias, culturas e sujeitos desempenha na formação dos intelectuais e, em particular, dos intelectuais negros. Aqui, as reflexões do sociólogo afro-britânico Paul Gilroy acerca da conformação das culturas, políticas e identidades negras no Atlântico são centrais e contribuem para dimensionar os impactos que os deslocamentos internacionais de Carmichael exerceram na (re)elaboração de suas perspectivas. Segundo Gilroy, os projetos, pertencimentos e manifestações culturais negras devem ser compreendidos não em relação a um núcleo tradicional invariante tido como "essencial" e "fixo" - a ideia de "raízes" ou "origens" estanques, por exemplo -, mas como fenômenos dinâmicos resultantes das múltiplas "rotas", desenraizamentos e trocas que compõem a experiência e as diásporas negras na modernidade ocidental. Para o sociólogo, isto implica conceber tais fenômenos como produtos necessariamente interculturais e híbridos que escapam aos limites das nações, dos nacionalismos e das filiações étnicas mais estreitas e que se constituem no espaço transnacional circunscrito pelo "Atlântico Negro"- isto é, entre as Américas, África e Europa. ${ }^{17}$

Assim, tomando emprestada essa importante categoria de análise de Gilroy, buscamos situar - e, inclusive, tensionar - o pensamento e a atuação de Stokely Carmichael em meio às redes de sociabilidade, projetos políticos e formulações identitárias transnacionais apropriadas por ele de distintos intelectuais negros do século XX. Em particular, destacamos a influência exercida na geração de Carmichael pelas reflexões de pensadores e lideranças políticas do Atlântico Negro como, por exemplo, os caribenhos Marcus Garvey, C.L.R. James, George Padmore e Frantz Fanon; os norte-americanos Martin Luther King, Bayard Rustin e, principalmente, Malcolm X; e, por último, os africanos Kwame Nkrumah e Sékou Touré.

No tocante ao tratamento das distintas conformações identitárias assumidas por Carmichael ao longo da década de 1960, destacamos as contribuições teóricas do sociólogo jamaicano Stuart Hall para o estudo das identidades culturais. Em consonância com o que propõe Gilroy acerca das culturas e intelectuais negros, Hall argumenta que as identidades pós-modernas originam-se das experiências de descentramento atravessadas pelo sujeito contemporâneo em um mundo altamente interconectado e globalizado. $\mathrm{O}$ autor - ele próprio um intelectual marcado pela descontinuidade característica da diáspora caribenha no Reino Unido - reitera que as identidades

Letras, 2005, p. 15; 25-27; 60-61; 66-70 e Idem. Reflexões sobre o exílio e outros ensaios. Companhia das Letras, 2003, p. 50-60.

${ }^{17}$ GILROY, Paul. O Atlântico Negro. Modernidade e dupla consciência. São Paulo: Editora 34, 2001. 
pós-modernas são fenômenos da ordem da contingência, fragmentários e dialógicos, que se (re)configuram segundo as maneiras pelas quais os sujeitos interpelam e são interpelados pelo mundo à sua volta. ${ }^{18}$

Podendo ser "ganhadas" ou "perdidas" segundo condicionantes (e constrições) cambiantes, as identidades pós-modernas tornaram-se "politizadas", fenômenos característicos da “paisagem política" introduzida pelos novos movimentos sociais da segunda metade do século $\mathrm{XX}$, dentre eles, os movimentos negros dos quais Stokely Carmichael participou. Nesse contexto de grande volatilidade, as filiações e perspectivas manifestas por Carmichael foram entendidas, portanto, na chave da identificação proposta por Hall: isto é, como processos inacabados, instáveis e em constante mutação, que assumem formas e ênfases distintas em consonância com as experiências vivenciadas, diagnósticos e programas políticos elaborados pelo ativista. ${ }^{19}$

Estabelecidas as questões dos intelectuais e das identidades, restam, ainda, alguns comentários conceituais acerca dos nexos entre identidade, raça e racismo que tangenciam esta pesquisa. Na esteira do que propõem, nos Estados Unidos, os sociólogos Michael Omi e Howard Winant, e, no Brasil, o jurista e filósofo Silvio Luiz de Almeida, "raça" é aqui compreendida como um construto social e histórico que, à maneira das identidades, adquire significados e usos cambiantes no tempo e no espaço. Segundo observam os autores, "raça" é um conceito relacional que, de um lado, é historicamente empregado por grupos hegemônicos para a (re)produção da desigualdade, da marginalização e da diferença com base em critérios raciais e fenotípicos; e, de outro, tem sido ressignificado pelos sujeitos racializados como fundamento de uma identidade coletiva voltada à agência política, isto é, à resistência à opressão. Por isso, a "raça" e o racismo a "forma sistemática de discriminação que tem a raça como fundamento", define Silvio Luiz de Almeida - constituem-se no "cruzamento" das estruturas com as representações, configurando categorias-chave à compreensão das formas pelas quais as identidades são assumidas ou designadas aos sujeitos contemporâneos a partir de condicionantes sociais, políticos, econômicos e simbólicos marcadamente distintos e desiguais. ${ }^{20}$

\footnotetext{
${ }^{18}$ HALL, Stuart. A identidade cultural na pós-modernidade. Rio de Janeiro: Lamparina, 2015 e Idem. Quem precisa da identidade? In: SILVA, Tomaz Tadeu (org. e trad.). Identidade e diferença: $a$ perspectiva dos Estudos Culturais. Petrópolis: Vozes, 2000. p. 103-133.

${ }^{19}$ HALL, Stuart. op. cit., 2015, p. 16 e HALL, Stuart. op. cit., 2000. p. 111-112.

${ }^{20}$ OMI, Michael; WINANT, Howard. Racial formation in the United States. 3a ed. New York and London: Routledge, 2015, p. 105-136 e ALMEIDA, Silvio Luiz de. O que é racismo estrutural? Belo Horizonte: Editora Letramento, 2018, p. 19-44.
} 
Em termos ajustados aos propósitos desta pesquisa, queremos dizer com isso que as identidades, reflexões intelectuais e os projetos políticos articulados por Stokely Carmichael não surgiram de um "vácuo"; muito pelo contrário, eram produtos profundamente ancorados nas questões, disputas e aspirações políticas de sua época. Suas ideias, portanto, respondiam às relações desiguais de poder, às dinâmicas concretas de expropriação material e de desumanização que impunham aos negros um lugar subalterno dentro e fora dos Estados Unidos. A produção e atividade de Stokely resultava, também, da sua inserção em distintas redes de sociabilidade intelectual e solidariedade política transnacionais que possibilitavam intercâmbios constantes com as lutas "terceiro-mundistas" do período e com os projetos políticos emancipatórios então vigentes entre distintos setores da diáspora negra.

Por último, ainda que este trabalho não se proponha a realizar uma História do Livro e da Leitura, os escritos de Carmichael e os projetos político-identitários que exprimiam - estes sim objetos de nossa análise - foram lidos, apropriados e discutidos por uma comunidade diversa de leitores. Nesse sentido, embora não nos dediquemos a uma análise detida da recepção das obras do ativista, cabe mencionar a relevância das reflexões do historiador Roger Chartier acerca do impresso para melhor situar o impacto e o alcance das ideias de Carmichael na segunda metade da década de 1960. Chartier mostra a necessidade de articular os significados dos textos concebidos pelo autor e pela edição tipográfica da obra às práticas de leitura próprias a um determinado período. Para ele, a leitura constitui uma prática criativa, produtora de novos sentidos que escapam às intenções originais de produção da obra. ${ }^{21}$

Não surpreende, portanto, que os posicionamentos públicos e a produção escrita de Stokely Carmichael tenham suscitado recepções marcadamente distintas entre os atores sociais dos anos sessenta - sobretudo no caso do livro Black Power: The Politics of Liberation, principal obra do ativista e única a atingir ampla circulação no período estudado. De um lado, suas ideias foram alvos de críticas mais ou menos contundentes por parte da grande imprensa norteamericana, setores moderados do movimento e até da intelligentsia negra; de outro, foram bem acolhidas e, posteriormente, ressignificadas a partir de novas questões e enfoques trazidos pela militância negra que se radicalizou durante o movimento Black Power.

${ }^{21}$ CHARTIER, Roger. Do livro à leitura. In: Liberdade, 2001. (org.). Práticas da Leitura. São Paulo: Estação da 
O trabalho divide-se temática, cronológica e analiticamente em duas partes principais. Nos dois primeiros capítulos, partimos de um relato das origens de Stokely Carmichael no Caribe Inglês para acompanhar a trajetória inicial do ativista pelo Atlântico Negro, seguida da sua inserção no Movimento pelos Direitos Civis nos Estados Unidos através do engajamento com o SNCC e, por último, discutir a radicalização que levou a geração do ativista em direção a novas e independentes agendas políticas negras expressas pelo clamor por "Black Power!". Nesse primeiro momento, portanto, o enfoque consiste em compreender o contexto mais amplo de engajamento de Stokely até meados da década de 1960, desvelando as referências e espaços centrais à sua formação intelectual e política inicial.

$\mathrm{Na}$ segunda parte, o nosso foco se deslocou para a análise detida dos projetos políticos e das perspectivas identitárias formuladas pelo militante no âmbito do movimento Black Power e da luta pan-africanista. No terceiro capítulo, investigamos o diagnóstico e o programa antirracista propostos em Black Power: The Politics of Liberation, destacando a tensão entre os vínculos reformistas remanescentes na obra e as perspectivas revolucionárias subjacentes às reivindicações de Carmichael por orgulho racial e autodeterminação negra. Já no quarto capítulo, investigamos, a partir da documentação compilada em Stokely Speaks: From Black Power to Pan-Africanism, a reconfiguração (ou a "transnacionalização") das perspectivas do ativista após suas viagens pelo "Terceiro Mundo" e, sobretudo, pelo continente africano.

Por último, alguns avisos prévios: todas as citações das obras estudadas correspondem a traduções de nossa autoria. Aquelas, mais extensas, que figuram principalmente em recuo no corpo do texto, são acompanhadas dos trechos originais em inglês indicados em notas de rodapé. Procuramos, na medida do possível, manter o sentido original dos trechos e expressões em inglês, elucidando, quando necessário à compreensão da passagem, as escolhas de tradução e os correspondentes originais. Além disso, em certas ocasiões o leitor perceberá o uso de sinalização - principalmente na forma de parênteses - para indicar a alternância entre tempos verbais utilizados como, por exemplo, no trecho: "insidioso que era (é), o racismo constituía uma ideologia que perpassa(va) todo o imaginário social”.

Julgamos que isso, à primeira vista um expediente textual dentre tantos outros, configura, em realidade, uma escolha ligada à enunciação do tempo daquele que escreve, do "aqui e agora" que orienta e implica a escrita do historiador. Portanto, mais do que perturbar o distanciamento 
que se impõe entre o passado do objeto de estudo e o presente do trabalho, o intuito é refletirmos acerca das rupturas mas também das permanências no nosso presente de formas de opressão contra as quais, nas décadas de 1950 a 1970, insurgiam-se Stokely Carmichael e a geração dos Direitos Civis e do Black Power. Ainda que de maneira muito sutil, essas pequenas quebras na leitura buscam exprimir a necessidade de mantermos - autor e leitor - um olhar vigilante, atento às estruturas históricas do racismo, bem como às suas contínuas reconfigurações e enraizamentos em nosso tempo e espaço. Em suma, implica reconhecermos que, em 2019, seja nos Estados Unidos ou no Brasil, as palavras de alerta proferidas pelo abolicionista negro Frederick Douglass ao final da Guerra Civil norte-americana (1861-1865) revelam-se, uma vez mais, assustadoramente proféticas:

"A escravidão tem se denominado de diversas maneiras. Ela já foi nomeada de a 'instituição peculiar', o 'sistema social' e o 'entrave'. Ela tem sido chamada por um grande número de nomes e vai, ainda, chamarse por outro. E é bom que você e eu e todos nós esperemos para ver qual a nova forma que este antigo monstro irá assumir e sob qual nova pele esta antiga serpente se apresentará". 22

22 "Slavery has been fruitful in giving itself names. It has been called the 'peculiar institution', 'the social system', and the 'impediment'. It has been called by a great many names, and it will call itself by yet another name; and you and I and all o fus had better wait and see what new form this old monster will assume, in what new skin this old snake will come forth next". DOUGLASS, Frederick apud CHA-JUA, Sundiata Keita. The New Nadir: The contemporary black racial formation. Black Scholar, v. 40, n. 1, spring 2010, p. 38. 


\section{CAPÍTULO 1 - Formação e início do ativismo político de Stokely Carmichael (1960-1964)}

Neste capítulo buscaremos apresentar a trajetória inicial de Stokely Carmichael partindo das suas origens no Caribe inglês, passando pela sua mudança para Nova York e para Washington, onde cursou filosofia na Howard University, e, por fim, encerrando com a sua participação na segunda metade da "fase clássica" do Movimento Pelos Direitos Civis - isto é, entre os anos de 1960 e 1964. Por este recorte propomos discutir a inserção de Carmichael nos principais processos e tradições políticas que pautavam a atuação política do movimento negro dos Estados Unidos do período. Participando da luta nacional dos afro-americanos por direitos políticos e melhores condições de vida, o ativista atuou principalmente no Mississippi, Sul do país, mas também em Washington e no estado de Maryland.

Aqui focaremos no lugar particular ocupado pelo ativista no movimento graças à sua filiação ao NAG - Nonviolent Action Group e ao SNCC - Student Nonviolent Coordinating Committee, grupo estudantil interracial no qual ele se formou politicamente. As relações estabelecidas entre o SNCC, as distintas organizações dos Direitos Civis e o Governo Federal dos Estados Unidos são essenciais para compreender a radicalização política vivenciada, em meados da década, por boa parte da geração de ativistas da qual Carmichael fazia parte. Naquele momento, ancorado nas propostas políticas democráticas do SNCC e nas experiências vividas em meio ao Movimento pelos Direitos Civis, o ativista voltou-se para uma crítica de fundo radical à sociedade norte-americana por via da proposição do Black Power, assunto este que abordaremos nos próximos capítulos.

\subsection{Do Caribe aos Estados Unidos: Stokely Carmichael, um "sobrevivente da dispersão" (1941-1952)}

"A diáspora significa sobrevivência. Como a maioria das famílias africanas da diáspora, minha família é uma coleção de pessoas que são comuns, mas de uma maneira extraordinária. Não reivindico nenhuma distinção para nós. Como todos os vizinhos e amigos nas comunidades próximas - seja em Trinidad, no Bronx ou no Mississippi - somos simplesmente os sobreviventes da dispersão". ${ }^{23}$

\footnotetext{
23 "Diaspora means survival. Like most African families of the diaspora, my family is a collection of people who are ordinary in extraordinary ways. I claim no special distinction for us. Like all our neighbours and friends in the surrounding communities - whether in Trinidad, the Bronx, or Mississippi we are simply the survivors of dispersal". CARMICHAEL, Stokely; THELWELL, Ekwueme Michael.
} 
Stokely Standiford Churchill Carmichael nasceu em 29 de junho de 1941 na cidade de Porto de Espanha, capital de Trinidad e Tobago, então colônia inglesa nas Índias Ocidentais caribenhas. Sua família, oriunda de distintos pontos do Caribe anglófono, foi marcada pelos frequentes fluxos populacionais - forçados ou não - característicos da diáspora negra nas Américas. Norte-americana por acidente, sua mãe, Mabel (May) Charles, era originária da Zona do Canal do Panamá, faixa territorial estratégica para a geopolítica dos Estados Unidos na América Central. À época do nascimento de May, os avós maternos de Carmichael, vindos de Montserrat e Antigua, residiam na região do Canal em cuja construção seu avô trabalhou. Do lado de seu pai, Adolphus Carmichael, sua ascendência remontava à Trinidad e Tobago e à pequena ilha de Barbados, esta também uma possessão ultramarina da Coroa Inglesa. ${ }^{24}$

A família de Carmichael pertencia a um estrato social médio, relativamente privilegiado em relação à dura realidade enfrentada pela população da ilha. Durante a Segunda Guerra Mundial, a circulação de tropas aliadas na base naval norte-americana de Chaguaramas a oeste de Porto de Espanha favoreceu um aquecimento temporário da economia local, atraindo levas de trabalhadores do interior buscando os "dólares ianques". Segundo lembra Stokely, o influxo populacional contribuiu para intensificar as difíceis condições de vida da população ao agravar o desemprego e o subemprego na região. ${ }^{25}$

Insulados deste cenário, os parentes paternos de Carmichael - compostos pela avó, três tias e um primo - eram proprietários e residentes na casa construída por Adolphus na qual, em determinado momento, também morou o núcleo familiar imediato de Stokely - pai, mãe e irmãs. A condição financeira estável era mantida pelo trabalho de suas tias - todas empregadas - e, posteriormente, também pelo dinheiro enviado por Adolphus e May de Nova York. Estes, ao final da Guerra, mudaram do Caribe para o bairro do Bronx onde então residiam os avós maternos de Stokely. Deixado em Trinidad e Tobago aos cuidados da avó Cecilia, Carmichael só voltaria a morar com os pais novamente seis anos depois quando, em 1952, a morte da matriarca precipitou a mudança de toda a família para os Estados Unidos. ${ }^{26}$

Até aquele momento, entretanto, Stokely passou seus primeiros dez anos de vida em um

Ready for the Revolution: The Life and Struggles of Stokely Carmichael (Kwame Ture). New York: Scribner, 2003, p. 14.

${ }^{24}$ Ibidem, p. 14-16

${ }^{25}$ Ibidem, p. 28-29.

${ }^{26}$ JOSEPH, Peniel E. op. cit., 2014, p. 6-8. 
ambiente colonial e portuário pautado por uma forte amálgama cultural. Em meio a comunidade majoritariamente negra de Porto de Espanha, os carnavais e ritmos da música afro-caribenha (calipso) coexistiam com elementos característicos da vida nas colônias imperiais britânicas como a prática do futebol e do críquete, a leitura de literatura inglesa e a realização do Empire Day, celebração anual na qual entoavam-se os hinos Rule Britannia e God Save the Queen em louvor à monarquia. Tais ocasiões buscavam reforçar a identificação dos colonos com o Império iniciada, desde cedo, nas salas de aula que frequentavam: nos livros escolares, lembra Carmichael, referências ao rigoroso inverno europeu, sua flora e fauna específicas, contrastavam diretamente com a realidade tropical vivida pela população de Trinidad e Tobago. ${ }^{27}$

Assim, a despeito de sua onipresença na ilha, Carmichael recordaria posteriormente que o colonialismo se afigurava largamente invisível aos olhos de uma criança ajustada às práticas e aos símbolos imperiais. De fato, ancorado em sua experiência escolar colonial na Eastern Boys School, instituição Britânica de ensino gratuito aos locais, o jovem Stokely conciliava, à época, vivências marcadamente distintas: juntamente às raízes diaspóricas de sua família, ele ainda carregava consigo uma identificação com a cultura anglófona e imperial dispersa pelo Caribe - a começar, por exemplo, pelo seu nome do meio, "Churchill". 28

Por outro lado, embora a incorporação de elementos da cultura imperial fosse parte significativa da sua infância, a vivência colonial de Carmichael não se apresentava livre de contradições. Inserido em um meio social caribenho majoritariamente negro, o contato com europeus brancos - isolados na alta burocracia imperial de "expatriados" e em uma pequena elite proprietária de terras - afigurava-se uma realidade muito remota ao cotidiano de Stokely e da

\footnotetext{
${ }_{27}^{27}$ Ibidem, p. 7; CARMICHAEL, Stokely; THELWELL, E. M. op. cit., 2003, p. 30-37.

${ }^{28}$ JOSEPH, Peniel E. op. cit., p. 7. Para uma reflexão sobre um intelectual diaspórico e a colonização, cf. HALL, Stuart. A formação de um intelectual diaspórico: uma entrevista com Stuart Hall, de Kuan-Hsing Chen. In: ; SOVIC, Liv (org.). Da Diáspora. Identidades e Mediações Culturais. 2a ed. Belo Horizonte: Editora UFMG, 2018, p. 451-480. Conforme veremos em capítulos subsequentes, posteriormente Carmichael manifestaria uma visão radicalmente distinta da experiência colonial. No entanto, aqui é curioso destacarmos como, na década de 1960, o ativista ressignificaria suas vivências no Caribe Britânico à luz das suas perspectivas adultas no Movimento Black Power. Discursando em Londres em 1967, ele disse: "Tenho alguma coisa contra a Inglaterra. Sinceramente. Porque, quando jovem, tive de ler toda aquela baboseira sobre o quanto a Inglaterra era boa para Trinidad [e Tobago] ao mesmo tempo em que ela nos saqueava à torto e à direito. Quando eu era pequeno, tudo o que eu lia a respeito de Londres era a sua beleza, a vida tranquila que todos viviam e como era boa a vida às minhas custas. $E$ eu costumava dizer: 'Bem que eu gostaria de ir até Londres e destruí-la a fogo"'. PEREIRA, Amauri M. (org.); CARMICHAEL, Stokely. O Poder Negro. 2a ed. Belo Horizonte: Ed. Nandyala, 2018, p. 26. Itálicos nossos.
} 
população local acostumados ao predomínio de nativos nos postos mais próximos da administração pública: policiais, professores, enfermeiros, motoristas de ônibus, inspetores sanitários. Em uma passagem de sua autobiografia, o autor ilustra esse distanciamento ao recordar a visita da Princesa Margaret à ilha durante a qual, encoberta dentro de sua carruagem, passou rapidamente pelos presentes. Estes, motivados pela novidade, há horas aguardavam em pé a sua chegada. À época, segundo relembra Stokely, a sensação de frustração e estranhamento gerada pela impessoalidade do episódio manifestou-se na fala dos presentes: "ela obviamente sequer quis olhar para nós". 29

Dessa forma, enquanto a conciliação - por vezes contraditória - das distintas heranças do Caribe anglófono marcaram a infância de Carmichael, a mudança para os Estados Unidos inaugurou o seu processo de "afro-americanização". Segundo seu biógrafo, uma vez na cidade de Nova York, Stokely entrou em contato com "os ritmos e idiomas" que pautavam a vida cultural negra das grandes cidades do norte dos Estados Unidos. ${ }^{30}$ Em especial, a circulação por contextos urbanos multiétnicos nos bairros do Bronx, Morris Park e do Harlem expuseram-no às pungentes tradições políticas - brancas e, sobretudo, negras - que mobilizavam a cena radical nova-iorquina desde o começo do século. ${ }^{31}$

\subsection{A Nova York de Carmichael: espaços de formação política e intelectual (1952-1960)}

Em 1952, aos onze anos de idade, Stokely e seus parentes de Porto de Espanha mudaramse para o bairro do South Bronx onde, ao fim das férias de verão, o jovem voltou às aulas. Contudo, antes do término do seu primeiro ano escolar nos Estados Unidos, a família mudou-se novamente. Buscando mais espaço para abrigar a todos os recém-chegados, Adolphus e May adquiriram uma casa na Rua Amethyst, em Morris Park, outra região do Bronx. ${ }^{32}$

Para Stokely, a vida na nova residência representou, em parte, a entrada em um contexto

${ }^{29}$ CARMICHAEL, Stokely; THELWELL, E. M. op. cit., 2003, p. 35-37. JOSEPH, Peniel E. op. cit., 2014, p. 7.

${ }^{30}$ JOSEPH, Peniel E. op. cit., 2014, p. 8.

31 Não queremos dizer com isso que a vivência no Caribe não tenha marcado Carmichael, mas sim ressaltar a centralidade da ida aos Estados Unidos para o início de sua formação política e intelectual sobretudo, como veremos à frente, em meio a um contexto de grande mobilização entre os negros daquele país. Cabe aqui ressaltarmos que, além de Carmichael ter deixado o Caribe muito jovem, os relatos disponíveis acerca da sua infância em Trinidad são breves e memorialísticos, o que limitou a investigação acerca das influências caribenhas no seu pensamento e trajetória posteriores.

${ }^{32}$ CARMICHAEL, Stokely; THELWELL, E. M., op. cit., p. 54-61. 
social marcado por um intenso contato interracial que se contrapunha às suas experiências pregressas no Caribe. Carmichael e seus parentes eram a única família negra a residir em Morris Park cujo perfil de classe trabalhadora comportava principalmente imigrantes italianos, mas também irlandeses e judeus. Neste ambiente, Stokely viveu um período de imersão na cultura italiana ao tornar-se amigo das crianças do bairro. Socializando mais facilmente que sua família todos metodistas negros vivendo em um espaço povoado por brancos e católicos de origem europeia -, Carmichael circulava pela Little Italy de Morris Park, adequando-se à culinária, aos trejeitos e à prática dos pequenos delitos que pautavam o cotidiano da juventude ítalo-americana do seu convívio. ${ }^{33}$

No entanto, ao passo que sua facilidade de adaptação era notável, Carmichael não se reconhecia e nem se integrava plenamente em seu grupo. Apelidado de Sichie pelos colegas - um derivativo de "siciliano" utilizado em referência ao tom de pele escura do jovem - Stokely manifestava o que o grande intelectual e ativista afro-americano W.E.B. Du Bois classificara como a "dupla consciência" dos negros nos Estados Unidos, isto é, uma dualidade irreconciliável de pertencimento identitário dividindo-o entre "um lado americano e um lado negro". ${ }^{34}$ Dessa forma, segundo Carmichael lembraria décadas depois, a sua vivência no meio social branco de Morris Park jamais ocorrera livre de tensões; ao contrário, ela se destoava significativamente da identificação e das sociablidades que o jovem e sua família construíam com as comunidades caribenhas e afro-americanas dispersas pelos bairros de Nova York. ${ }^{35}$

"Por um lado, eu nunca me integrei completamente à cultura jovem e masculina do bairro como pode ter parecido. Apesar das minhas atividades de gangue de rua, minha fluência no linguajar italiano e meu apelido Sichie, eu claramente estava nessa cultura, mas na verdade não fazia parte dela. Nós éramos negros e o bairro era branco. Nossa

\footnotetext{
33 JOSEPH, Peniel E. op. cit., 2014, p. 9-10.

${ }^{34}$ Sociólogo, historiador, ativista, autor e editor, William Edward Burghart Du Bois (1868-1963) foi um dos mais influentes intelectuais afro-americanos do século XX. No decorrer de sua longa trajetória de 95 anos, Du Bois iniciou como um ativista opositor da segregação racial nos Estados Unidos, mas também foi um dos grandes expoentes do movimento pan-africanista no Atlântico Negro e um forte crítico do colonialismo e do imperialismo ocidentais que terminou a vida radicado em Gana. Dentre toda a sua vasta produção intelectual, destacamos o seu seminal As Almas da Gente Negra (The Souls of Black Folk) no qual desenvolve o conceito de "dupla consciência" citado. Para uma discussão do conceito e da obra de Du Bois, cf. GILROY, Paul. op. cit., 2001, p. 245-280.

${ }^{35}$ Entrevista de Stokely Carmichael em WARREN, Robert Penn. Who Speaks for the Negro? 2. ed. New Haven and London: Yale University Press, 2014, p. 390-391 e CARMICHAEL, Stokely; THELWELL, E. M., op. cit., p. 63-68;
} 
socialização e nossa identificação deu-se com uma extensa família de africanos [i.e., negros], a princípio em sua maioria de origem caribenha, mas crescendo para incluir os africanos nascidos nos Estados Unidos. Nos feriados, aos domingos depois da igreja, trocávamos visitas em volta de elaboradas refeições caribenhas, música e conversas. Ou então haviam piqueniques em um ou outro parque da cidade onde desfrutávamos de jogos e do futebol. Assim, embora vivêssemos confortavelmente em uma Little Italy, a nossa vida social e expressão cultural e renovação dependia de uma extensa rede de amigos e familiares que cruzavam comunidades africanas em três bairros da cidade: Brooklyn, Queens e Harlem". ${ }^{36}$

\subsubsection{Harlem: confluência de tradições políticas negras}

No Harlem, diferentemente de onde morava, Stokely deparou-se com um ambiente urbano dotado de uma cultura afro-americana vibrante. Por anos, durante idas regulares ao bairro - no qual frequentava uma tradicional barbearia, importante ponto de encontro da comunidade negra local - ele presenciou intensas discussões políticas que, à época, acompanhavam o acirramento dos conflitos raciais nos estados do Sul dos Estados Unidos. Dentre as pautas que galvanizavam os ânimos dos presentes, destacavam-se dois importantes acontecimentos do período: a decisão da Suprema Corte no caso de Brown vs. Board of Education of Topeka, Kansas (1954) e o assassinato de Emmett Till no Mississippi (1955). ${ }^{37}$

Em 1954, enquanto Carmichael tornava-se cidadão norte-americano aos treze anos de idade, a decisão de Brown vs. Board infligiu um importante golpe ao edifício da segregação racial. Na ocasião, ao determinar a inconstitucionalidade da segregação racial praticada nas escolas públicas de todo o país, a Suprema Corte dos Estados Unidos assegurou uma importante vitória para os advogados da $N A A C P$ - National Association for the Advancement of Colored People, organização interracial responsável por levar o caso a julgamento. Desde sua fundação

\footnotetext{
36 "For one thing, I was really never completely integrated into the neighborhood's young male culture as it might have appeared. In spite of my street gang activity, my fluency in Italian invective, and my popular name Sichie, clearly I was in that culture but really not part of it. We were black and the neighborhood was white. Our socializing and our identification were with an extended family of Africans, at first mostly of Caribbean origin, but growing to include Africans born in the United States. On holidays, on Sundays after church, we would exchange visits for elaborate Caribbean meals, music, and conversation. Or there would be the picnics in one or another of the city parks where we'd enjoy games and play soccer. So although we lived comfortably in a Little Italy, we depended for our social life and cultural expression and renewalon an extended network of friends and family that crisscrossed African communities in three boroughs of the city: Brooklyn, Queens, and Harlem”. CARMICHAEL, Stokely; THELWELL, E. M., op. cit., p. 67-68.

${ }^{37}$ Ibidem, p. 74; JOSEPH, Peniel E., op. cit., 2014, p. 10-11.
} 
em 1909 por W.E.B. Du Bois, a NAACP promovia uma longa luta no Judiciário e no Congresso norte-americanos em prol dos direitos políticos e civis dos negros do Sul e do Norte do país. Recorrendo a estas arenas tradicionais de atuação política, a organização liderou numerosas iniciativas legais contra a discriminação racial que impedia os afro-americanos de participarem, em igualdade de condições, dos mais variados aspectos da vida pública norte-americana: no serviço militar, no processo eleitoral e até no acesso aos transportes públicos, instituições de ensino e ao serviço de júri. ${ }^{38}$

Em meio a variedade de iniciativas protagonizadas pela NAACP, a vitória em Brown vs. Board adquiriu um significado especial para o ativismo negro. Ao reverter as determinações anteriores de Plessy vs. Ferguson (1896) - segundo as quais a segregação de espaços públicos não violava a igualdade de direitos garantida pela Constituição a todos os cidadãos do país - o caso abriu um importante precedente legal contra a segregação racial. Nesse sentido, após a decisão de Brown vs. Board of Education of Topeka, a máxima de brancos e negros, "separados, mas iguais", chancelada pelo caso Plessy vs. Ferguson, caiu por terra. ${ }^{39}$

Pouco tempo depois, em 1955, o brutal assassinato do jovem negro Emmett Till, no estado segregacionista do Mississippi, gerou uma onda de comoção e revolta por todo o país. Till, quatorze anos de idade, foi atacado por ter supostamente assoviado para ou se dirigido a uma mulher branca. A indignação com o horror que marcou o episódio, agravada pela absolvição dos assassinos por um júri branco, conferiu um impulso importante para a nacionalização da agenda dos Direitos Civis. Paralelamente, ativistas vinculados à NAACP lançaram, poucos meses depois, o boicote aos ônibus da cidade de Montgomery, Alabama, iniciativa importante para a conformação das primeiras pautas e estratégias de resistência empregadas pelo movimento negro no período.

\footnotetext{
${ }^{38}$ LAWSON, Steven F. Running for freedom. Civil Rights and black politics in America since 1941. 3a ed. Wiley-Blackwell, 2009, p. 2-3; 11.

${ }^{39}$ SITKOFF, Harvard. The Struggle for Black Equality. New York: Hill and Wang, 2008, p. 35-44. Em 1896, a decisão da Suprema Corte dos Estados Unidos no caso Plessy vs. Ferguson estabeleceu as bases legais sobre as quais se assentaram o Jim Crow, designação pela qual era conhecido o sistema de segregação racial nos estados do Sul. Naquele contexto, John Howard Ferguson, juiz que presidia o caso, determinou que a doutrina "separados mas iguais" (separate but equal) não representava uma violação da $14^{\mathrm{a}}$ Emenda à Constituição segundo a qual todos os cidadãos norte-americanos eram iguais perante a lei. A partir daquele momento, diversos estados norte-americanos, com destaque aos sulistas, empenharam-se na imposição da segregação racial em espaços e serviços públicos, submetendo a população negra do país a instalações e instituições públicas separadas e muito inferiores em relação àquelas disponíveis aos brancos.
} 
Considerados marcos da consciência nacional referentes à questão dos Direitos Civis da população negra, a decisão de Brown vs. Board of Education of Topeka, Kansas, o assassinato de Till e o boicote aos ônibus de Montgomery, foram estopins decisivos para a ascensão da agenda política do movimento negro na segunda metade da década de 1950. Neste sentido, para além da repercussão midiática que os envolveram, tais eventos reacenderam um debate nacional em torno dos distintos projetos políticos voltados à população afro-americana em vigor no período que Stokely Carmichael iniciava sua formação política e intelectual.

Naquele momento, em cidades do Norte como Chicago e Nova York, ambiente com o qual Carmichael tinha contato, intelectuais e ativistas afro-americanos rearticulavam tais perspectivas ancorados em tradições políticas negras que remetiam ao contexto do New Negro Movement. ${ }^{40}$ Produto do período Entreguerras (décadas de 1920-1930), esse movimento mobilizava correntes políticas moderadas que variavam da defesa da plena integração do negro na sociedade e vida cultural do país até as mais radicais que propunham a renúncia à cidadania norte-americana por parte dos afro-americanos. A despeito das diferenças, tanto liberais quanto radicais negros colocavam em xeque as prerrogativas racistas da supremacia branca e, com isso, recusavam os limites estreitos da cidadania norte-americana que excluíam os negros do acesso a direitos e garantias constitucionais mínimas. ${ }^{41}$

No Harlem, berço histórico do New Negro Movement, tais tradições se cruzavam em um complexo cenário político negro no qual, durante a década de 1950, coexistiam desde

\footnotetext{
${ }^{40} \mathrm{O}$ New Negro Movement surgiu em meio à Grande Migração que, no começo do século XX, deslocou milhões de afro-americanos dos estados segregacionistas do Sul para os centros urbanos do Norte - em especial Chicago e Nova York - motivados por promessas de melhores condições de vida. Nas primeiras décadas do século XX, esse movimento deu espaço a lideranças e intelectuais negros ativos no combate ao racismo e à segregação racial como o mecionado W.E.B Du Bois, sociólogo e fundador da NAACP, o militante jamaicano radical Marcus Garvey, a ativista da luta contra linchamentos Ida B. Wells, dentre outros. Esses expoentes contrapunham-se ao conservadorismo de Booker T. Washington, liderança que endossava o integracionismo do negro de forma "não conflituosa", gradual e pela via da formação técnica e profissional. Rotulando Washington como um Old Negro subserviente à opressão e segregação raciais, aqueles ativistas advogavam o lugar de "novos negros" dedicados à defesa contundente da dignidade e da igualdade de direitos para a população afro-americana. FRANCISCO, Flávio Thales Ribeiro. O Novo Negro na Diáspora. Modernidade Afro-Americana e as Representações sobre o Brasil e a França no Jornal Chicago Defender (1916-1940). São Paulo: Intermeios, 2016, p. 33-36; 76-77.

${ }^{41}$ Ibidem, p. 74. É importante destacarmos que o termo liberal a que referimos diz respeito, no contexto dos Direitos Civis norte-americanos, à perspectiva reformista e integracionista das lideranças negras daquele movimento - como Martin Luther King, Roy Wilkins da NAACP e Whitney Young da NUL (National Urban League) - que reivindicavam do Estado a realização de transformações institucionais e legais a fim de assegurar o fim da segregação racial e promover a integração do negro na sociedade.
} 
integracionistas liberais a sindicalistas, comunistas negros e garveyistas radicais. ${ }^{42}$ Segundo recorda Carmichael, tais correntes convergiam nas discussões e debates presenciados por ele em meio aos espaços de sociabilidade da comunidade afro-americana local, as ruas e lojas da região:

"Em um dia movimentado, uma ampla gama de opiniões e comentários políticos, notícias comunitárias, nacionais e internacionais eram ouvidas e dissecadas. Na loja [barbearia que frequentava] entravam Garveyistas, homens da raça [race men], malandros de rua [street players], republicanos negros e muçulmanos negros, nacionalistas de todos os tipos e rappers, poetas e wordmen que pareciam conversar simplesmente pela alegria de ouvirem suas próprias vozes". ${ }^{3}$

Em meio à efervescência política encontrada por Stokely nestas ocasiões, os passeios pelo bairro - realizados juntamente a sua prima Inez, uma residente local - representavam, sobretudo, um primeiro contato do jovem com as pujantes tradições políticas do nacionalismo negro e do pan-africanismo. Remontando às lutas e reflexões de abolicionistas negros do século XIX como Henry Highland Garnet, Martin Delany e, por um tempo, Frederick Douglass, o nacionalismo negro dizia respeito não a um discurso patriótico entre os afro-americanos, mas à ideia separatista de uma "nação" negra cultural, política e economicamente autônoma em relação à comunidade branca norte-americana mais ampla. ${ }^{44}$ No decorrer do século XX, como discutiremos nas páginas à frente, distintas organizações negras esposaram esta perspectiva dentre as quais a UNIA Universal Negro Improvement Association de Marcus Garvey e a Nação do Islã de Elijah Muhammad e Malcolm X tornaram-se as mais conhecidas.

Por sua vez, o pan-africanismo constituía um movimento político e cultural que comportava a ideia de um "destino comum" compartilhado pelos africanos e pelos negros da diáspora. No princípio, partindo da diáspora, o movimento atravessou por distintas fases e propositores como o antilhano Edward Wilmot Blyden (1832-1912) que objetivavam "regenerar" e unificar a África, promovendo a solidariedade entre os povos negros do mundo e até, em alguns

${ }^{42} \mathrm{O}$ termo garveyista aqui empregado diz respeito aos apoiadores de Marcus Garvey, militante e líder jamaicano radical cuja atuação política discutiremos à frente. JOSEPH, Peniel E. Waiting 'Til the Midnight Hour. A Narrative History of Black Power. New York: Holt, 2007, p. 11.

43 "On a good day, a wide range of political opinion and commentary, and community, national and international news was to be heard and dissected. There came into the shop old Garveyites, race men, street players, black Republicans and Black Muslims, nationalists of all descriptions, and the rappers, poets, and wordmen who seemed to talk simply for the joy of hearing their own voices". CARMICHAEL, Stokely; THELWELL, E.M. op. cit., p. 74.

${ }^{44}$ FRANCISCO, Flávio Thales Ribeiro. op. cit., p. 80; SHAWKI, Ahmed. Libertação negra e socialismo. Editora Sundermann, 2017. 
casos, defendendo o seu retorno ao continente. Posteriormente, em meados do século XX, sobretudo a partir do V Congresso Pan-Africanista de Manchester, Inglaterra, em 1945, o panafricanismo centrou-se em África e passou a tratar das lutas pela independência, por "integração continental e [pela]a unidade política, econômica e cultural [africanas], tornando-se assim, um amplo movimento de libertação da África". 45

À época, ambas correntes constituíam elementos importantes da vida cultural e política da população negra local do Harlem, manifestando-se nos distintos espaços públicos pelos quais o jovem Carmichael circulava. Exemplo disso, na African National Memorial Bookstore, célebre livraria pela qual transitavam intelectuais e políticos radicais da região, Carmichael teve acesso a leituras que se revelaram referências importantes para a sua formação política posterior. ${ }^{46}$ Entre estas, os livros Os Jacobinos Negros: Toussaint L'Ouverture e a Revolução de São Domingos de C.L.R. James e Pan-Africanism or Communism do trinitino George Padmore, foram-lhe particularmente significativos. Padmore, importante expoente do pan-africanismo no pós-Guerra, era conselheiro político e uma influente referência intelectual para Kwame Nkrumah, líder da independência e presidente de Gana (1957-1966) que, cerca de uma década depois, figuraria como um mentor para Carmichael no âmbito do pan-africanismo. ${ }^{47}$ Por sua vez, a leitura de $O s$ Jacobinos Negros, trabalho seminal sobre a Revolução Haitiana de finais do século XVIII e início do XIX, fomentou o interesse crescente do jovem pela história negra nas Américas o qual ele explorava em visitas regulares ao Schomburg Center, instituto referência para o estudo da cultura afro-americana situado no Harlem. ${ }^{48}$

Nas ruas do bairro, oradores públicos (stepladder speakers), muitos deles remanescentes da UNIA - Universal Negro Improvement Association, organização negra fundada em 1914 pelo

${ }^{45}$ PARADA, Mauricio; BON MEIHY, Murilo Sebe; MATTOS, Pablo de Oliveira. História da África Contemporânea. Rio de Janeiro: Ed. Puc-Rio : Pallas, 2013, p. 55-56.

46 Durante décadas, a livraria, fundada pelo ex-garveyista Lewis Michaux nos anos 1930, foi um importante ponto de sociabilidade política entre os afro-americanos do Harlem. Nos anos 1950, por exemplo, a livraria tornou-se palco dos comícios políticos organizados por Malcolm X, expoente da Nação do Islã que era próximo de Michaux. JOSEPH, Peniel E. op. cit., 2007, p. 11-12.

47 JAMES, C.L.R. Os Jacobinos Negros: Toussaint L'Ouverture e a Revolução de São Domingos. Boitempo, 2007; PADMORE, George. Pan-Africanism or Communism? London: Dennis Dobson, 1996. Anos depois, este livro de Padmore é citado, por exemplo, em um importante artigo escrito por Carmichael em novembro de 1969 para a edição inaugural do periódico Black Scholar no qual o ativista discute suas perspectivas pan-africanistas pautado pelas ideias de Nkrumah. Cf. CARMICHAEL, Stokely. Pan-Africanism - Land and power. Black Scholar, v. 1, n. 1, nov. 1969, p. 36-43.

${ }^{48}$ CARMICHAEL, Stokely; THELWELL, E. M., op. cit., p. 104-105; JOSEPH, Peniel E. op. cit., 2014, p. 17. 
militante jamaicano radical Marcus Garvey (1887-1940), informavam os transeuntes acerca dos recentes desenvolvimentos das lutas negras por independência na África e no Caribe. ${ }^{49}$ Remetendo aos temas nacionalistas negros e pan-africanistas que pautaram as atividades da UNIA nos Estados Unidos das décadas de 1910 e 1920 - quando a organização entrou em colapso em decorrência de problemas financeiros que levariam à condenação de Garvey por fraude financeira e sua eventual deportação para a Jamaica -, os garveyistas promoviam uma mensagem de dignidade negra ancorada na valorização das culturas e realizações dos povos africanos contemporâneos e do passado. ${ }^{50}$

Herdeiros do garveyismo do começo do século, os oradores públicos presenciados por Carmichael "profetizavam" um futuro de autonomia política e dignidade para os países africanos, defendendo a importância da descolonização do continente e do Caribe para os afro-americanos de finais da década de 1950. Alguns deles, ornados com vestimentas tradicionais, cercados pelas cores verde, vermelho e preto associadas às lutas africanas por libertação e dotados de retórica envolvente, deixaram uma profunda impressão no jovem Stokely. ${ }^{51}$ Anos depois, Carmichael apontaria esses radicais do Harlem - bem como os pregadores das Igrejas Batistas sulistas como referências importantes mobilizadas por ele para a consolidação de sua oratória militante:

"O efeito dos oradores em mim foi mais do que político, foi retórico. $\mathrm{Ou}$ seja, além da mensagem havia uma influência de estilo. Elementos importantes do estilo da minha oratória adulta - as técnicas de falar em público com a cadência e dramaticidade características da tradição oral [spoken word] afro-americana, podem ser atribuídas a esses oradores do

\footnotetext{
${ }^{49}$ Figura de grande influência para gerações de negros radicais do Harlem, Marcus Garvey baseava suas perspectivas políticas em uma forte identificação com as civilizações ancestrais do Egito Faraônico e da Etiópia. Por meio do jornal de sua organização, o Negro World, o líder jamaicano promovia sua visão de uma "Nova África", um continente moderno que colocasse determinadas ideias e tecnologias ocidentais a serviço das necessidades da população negra. Neste sentido, dentre as principais propostas da UNIA figuravam o favorecimento do empreendedorismo negro e a criação da Black Star Line, companhia de viagens marítimas simbolicamente importante para a mensagem de "retorno a África" veiculada por Garvey. KELLEY, Robin D.G. Freedom Dreams. The Black Radical Imagination. Boston: Beacon Press, 2002, p. 23-29 e FRANCISCO, Flavio. op. cit., p. 79-83

${ }^{50}$ CARMICHAEL Stokely; THELWELL, E. M., op. cit., p. 100-101 e JOSEPH, Peniel E., op. cit., 2014, p. 16-17.

${ }_{51}$ Nestas ocasiões, ao discursarem acerca de processos revolucionários na África, oradores públicos representavam um primeiro contato de Carmichael como o pensamento e a atuação de uma gama de líderes africanos. Dentre os mencionados, figuravam Patrice Lumumba, líder da independência do Congo, o já mencionado Kwame Nkrumah e Ahmed Sékou Touré da Guiné. Cerca de uma década depois, na segunda metade dos anos 1960, Nkrumah e Touré figurariam como influências políticas e intelectuais centrais para Carmichael. CARMICHAEL Stokely; THELWELL, E. M., op. cit., p. 100-101
} 
Harlem. A eles e aos pregadores batistas do Sul rural". ${ }^{52}$

À época das visitas de Stokely, o radicalismo político negro do Harlem ressurgia, também, sob a influência de uma outra organização: a Nação do Islã. Competindo com os garveyistas por influência e espaço nas ruas do bairro, este grupo veiculava, desde a sua fundação em Detroit na década de 1930, uma mensagem de austeridade e profundo orgulho racial que atraía o público urbano negro marginalizado através da promessa de redenção pessoal pela via da unidade racial e religiosa. Defendendo o distanciamento de seus membros da vida política, a cosmogonia da Nação do Islã baseava-se em uma apropriação polêmica e eclética do islamismo, ciência mourisca e numerologia que buscava fornecer uma interpretação para a condição de opressão vivenciada pelos afro-americanos no país. Segundo pregava o mito fundador do grupo, os negros constituíam um poderoso "povo original" de proveniência asiática que havia sido subjugado pelo complô de Yacub, um vil “cientista” negro que, rezava a parábola, teria traído sua "raça" e criado os "demônios" brancos, os algozes dos negros mundo afora. A tarefa da Nação seria, portanto, "despertar" o povo original do torpor que lhes havia sido imposto pelo jugo dos brancos. $^{53}$

$\mathrm{Na}$ segunda metade dos anos 1950, a popularidade da organização crescia vertiginosamente nas cidades do Norte do país graças ao carisma de seu principal pregador, Malcolm X, e à influente publicação do Muhammad Speaks, periódico que divulgava a "palavra" de Elijah Muhammad, o líder espiritual da Nação do Islã. Ancorado nessa leitura particular do islamismo praticada pela organização, Malcolm impressionava a audiência com suas críticas contumazes à sociedade norte-americana desferidas em comícios e demonstrações públicas de disciplina do Fruto do Islã, o braço paramilitar da organização. ${ }^{54}$

52 "The effect of the speakers was more than political, it was rhetorical. That is, beyond the message there
was the influence of style. Important elements of my adult speaking style - the techniques of public
speaking in the dramatic African tradition of the spoken word, can be traced to these street-corner orators
of Harlem. To them and the Baptist preachers of the rural South". CARMICHAEL, Stokely;
THELWELL, E. M., op. cit., p. 100-102. O termo spoken word a que Carmichael se refere não possui um
correspondente exato em português. Em linhas gerais, como indicado na tradução, o autor se refere à
alternância de cadência e ritmos de fala constituintes de uma tradição retórica que atravessava o espectro
político negro, abarcando correntes reformistas e radicais. Nesse sentido, em seus discursos, Martin Luther
King Jr. e Malcolm X, para citar dois exemplos, eram extremamente habilidosos em aliar um timbre vocal
potente com a utilização de imagens e metáforas impactantes a fim de conquistar a audiência.
53 Sobre a cosmogonia e os mitos fundadores da Nação do Islã, cf. MARABLE, Manning. Malcolm X:
Uma Vida de Reinvenções. Companhia das Letras, 2017, p. 95-107.
54 OGBAR, Jeffrey O.G. Black Power: Radical Politics and African American Identity. Baltimore: The 
Em uma dessas ocasiões, segundo consta em sua autobiografia, Carmichael esteve presente. ${ }^{55}$ Conquanto impactante, é importante destacar que, naquele momento, o apelo carismático de Malcolm X não representava uma influência central para Carmichael como, posteriormente, ele de fato se tornou. A bem da verdade, Stokely discordava das críticas lançadas pelos nacionalistas negros à perspectiva integracionista defendida pelo "incipiente Movimento pelos Direitos Civis". Diferentemente do que pregava a Nação do Islã, por exemplo, o jovem, nesse momento, via o emprego de protestos e manifestações não-violentas pelo ativismo negro sulista como uma estratégia efetiva para a luta contra a discriminação racial. ${ }^{56}$ Ademais, residente em Morris Park, Stokely então retirava suas principais referências políticas do seu ambiente de convívio mais imediato na Bronx High School of Science. Nesta escola de reconhecida excelência, ele passou os quatro anos de ensino médio que antecederam sua mudança para a Howard University no segundo semestre de 1960.

\subsubsection{Carmichael a a Bronx High School of Science}

Repetindo um padrão recorrente na trajetória escolar de Carmichael em Nova York, o ingresso na Bronx High School inseriu-o em um ambiente com muito pouca representatividade negra entre o corpo discente. Por outro lado, o perfil intelectual e progressista da escola contribuiu, em parte, à sua socialização na instituição. Junto ao amigo Gene Dennis, filho de um oficial de alto escalão do Partido Comunista dos Estados Unidos (CPUSA, em inglês) perseguido durante o red scare, Stokely ingressou, assim, nos círculos políticos de esquerda da cidade de Nova York através de reuniões nas casas de colegas. ${ }^{57}$

Em meio à intelectualidade judaica, ele participou de grupos de estudos marxistas e

John Hopkins University Press, 2004, p. 19-23; 31.

${ }_{55}^{55}$ CARMICHAEL Stokely; THELWELL, E. M., op. cit., p. 100.

${ }^{56}$ Ibidem, p. 111.

57 JOSEPH, Peniel E., op. cit., 2014, p. 12. O red scare foi um período de forte repressão política anticomunista durante os anos 1950 nos Estados Unidos. Simbolizada pela campanha de "caça aos vermelhos" empreendida pelo senador Joseph McCarthy junto funcionalismo público do governo federal, a repressão estendeu-se a todos aqueles considerados subversivos pelas autoridades conservadoras: artistas, estudantes, intelectuais, funcionários públicos, jornalistas, homossexuais e ativistas dos Direitos Civis dos negros. De maneira geral, os ataques refrearam diversos impulsos reformistas e de crítica ao Estado, estabelecendo uma cultura de acomodação política - inclusive entre os jovens - superada, de maneira geral, somente com a ascensão dos movimentos negros e/ou estudantis nos anos 1960. Cf. PURDY, Sean. O Século Americano. In: KARNAL, Leandro; PURDY, Sean; FERNANDES, Luiz Estevam; MORAIS, Marcus Vinícius de. História dos Estados Unidos das origens ao século XX. $3^{\mathrm{a}}$ ed. São Paulo: Contexto, 2016, p. 230. 
envolveu-se com as atividades políticas da Young Communist League, a ala jovem do CPUSA, onde também aprendeu a cantar o Hava Nagila e a dançar a Hora, manifestações culturais caras ao povo judeu. De maneira geral, essas experiências introduziram-no a uma visão de mundo materialista ancorada na noção de luta de classes, perspectiva central à orientação marxistaleninista do círculo que frequentava, além de aproximar o jovem de uma posição política inicialmente favorável ao Estado de Israel. ${ }^{58}$

Não obstante, à época, a identificação de Stokely com o marxismo-leninismo comportava algumas contradições. Oriundo de uma família caribenha religiosa, ele encontrava dificuldades em conciliar o ateísmo professado pelos colegas marxistas com sua formação cristã dentro da Igreja Metodista negra. Ademais, como veremos em capítulos posteriores, na segunda metade da década de 1960, as divergências de Carmichael com o marxismo-leninismo assumiram formas mais propriamente seculares e ideológicas ancoradas na sua trajetória posterior de luta antirracista durante o Movimento Black Power e no pan-africanismo. Similarmente, também nesse período, o posicionamento pró-Israel de Stokely mudaria drasticamente: à medida que se radicalizavam, o ativista e boa parte da militância negra passaram a se solidarizar com a causa palestina por soberania nacional no Oriente Médio e a aproximarem-se de movimentos de libertação em vigência na África, Ásia e América Latina. ${ }^{59}$

Em um dos encontros realizados pelo seu círculo marxista na Bronx High School, o jovem Carmichael teve a oportunidade de encontrar com Bayard Rustin (1912-1987), exsocialista e ativista já bastante experiente que, desde o boicote aos ônibus de Montgomery em 1955, figurava como mentor de Martin Luther King Jr. na filosofia política da desobediência civil não-violenta. ${ }^{60} \mathrm{~A}$ presença de Rustin na reunião, um intelectual negro proeminente em meio à esquerda branca, impactou o jovem Carmichael de tal modo que deixou-lhe uma duradoura impressão. Por alguns anos, Bayard figurou como importante referência política para a sua atuação no escopo do Movimento pelos Direitos Civis do começo da década de 1960.

Em suma, os primeiros anos de Stokely em Nova York (1952-1960) comportaram experiências marcantes nos principais espaços em que circulava. Nesse ínterim, ambientes cultural, racial e economicamente tão diferentes como Morris Park, Harlem e Bronx High School

\footnotetext{
${ }^{58}$ JOSEPH, Peniel E., op. cit., 2014, p. 13 e CARMICHAEL Stokely; THELWELL, E. M., op. cit., p. $92-$ 95.

${ }^{59}$ Cf. CARMICHAEL Stokely; THELWELL, E. M., op. cit., p. 557-563 e CARSON, Clayborne. In Struggle. SNCC and the Black Awakening of the 1960s. Harvard University Press, 1981, p. 267-269.

${ }^{60}$ JOSEPH, Peniel E., op. cit., 2014, p. 8-14.
} 
of Science constituíram "laboratórios político-identitários" que permitiram ao jovem interagir de maneiras distintas com públicos diversos. ${ }^{61}$ De maneira complexa e, não raro, conflituosa, Harlem e Bronx High School combinaram-se para tornar a adolescência de Carmichael uma etapa particular, norte-americana, distinta de sua trajetória até então caribenha. Este processo, isto é, a "afro-americanização" das suas vivências e perspectivas, ganhou um forte impulso com a sua mudança para a Howard University no final de 1960 aos dezoito anos de idade.

\subsection{Stokely Carmichael: ativista do Movimento pelos Direitos Civis}

O ano de 1960 marcou a entrada da geração de Stokely Carmichael na cena pública nacional norte-americana. ${ }^{62}$ Para muitos destes jovens e intelectuais negros, seu primeiro engajamento político no Movimento pelos Direitos Civis acompanhou uma onda de protestos estudantis que, ao desafiar a segregação racial em espaços e acomodações públicas, mobilizou o ativismo negro em grande parte do Sul dos Estados Unidos. Inicialmente "autônomos" e depois coordenados por organizações atuantes na luta por Direitos Civis, os protestos foram decisivos para estabelecer os contornos gerais da atuação política desta geração de ativistas durante os primeiros anos da década de 1960 .

Para muitos dos participantes, o levante estudantil do começo do ano representou, sobretudo, um "acontecimento fundador" a partir do qual seus membros compartilharam experiências inspiradoras e, com frequência, violentas, de resistência ao racismo institucionalizado. No processo, forjaram uma "memória coletiva comum" acerca do seu engajamento e estabeleceram laços que fomentaram a solidariedade política entre esta geração, conferindo uma certa unidade de grupo aos ativistas iniciantes. ${ }^{63}$

Naquele momento, portanto, paralelamente às suas atividades escolares/universitárias, numerosos jovens negros engajaram-se em projetos desenvolvidos por organizações como o SNCC - Student Nonviolent Coordinating Committee e o CORE - Congress of Racial Equality, ${ }^{64}$

\footnotetext{
${ }^{61}$ Ibidem. p. 11.

${ }^{62}$ Ibidem, p. 19.

${ }^{63}$ SIRINELLI, Jean-François. Os intelectuais. In: RÉMOND, René (org.). Por Uma História Política. Editora FGV, 2003, p. 255.

${ }^{64}$ Ancorado no movimento pacifista norte-americano, CORE foi fundado na primavera de 1942 por um pequeno grupo interracial de estudantes-ativistas orientados por uma leitura cristã da não-violência gandhiana (Satyagraha). Estimulados pelas reformas sociais implementadas durante o New Deal de Franklin Delano Roosevelt e pelo ativismo afro-americano oriundo do combate ao nazismo na Segunda Guerra Mundial, membros do CORE endossavam uma orientação "reformista radical". Neste aspecto,
} 
discutidas à frente. Esse é o caso de Stokely Carmichael cujo envolvimento com os Direitos Civis e com as manifestações estudantis negras acompanharam (e inspiraram) sua mudança do Bronx High School of Science para a Howard University. Como discutiremos nas seções seguintes, durante os quatro anos de estudos passados por Carmichael na instituição (1960-1964), a Howard University proporcionou a sociabilidade política e intelectual sobre a qual os primeiros anos do ativismo político de Stokely se assentaram.

\subsubsection{Os sit-ins e a fundação do SNCC}

No início de 1960, o Movimento pelos Direitos Civis ganhou novo impulso proporcionado pela geração de Stokely Carmichael. Este, cursando o último semestre no Bronx High School of Science, ainda estava por definir o futuro acadêmico, decisão tomada por ele em meio à explosão de ativismo estudantil negro que mobilizou as universidades sulistas - Howard University, dentre elas.

Em fevereiro daquele ano, quatro estudantes negros da universidade de North Carolina A \& T, situada na cidade de Greensboro, assentaram no balcão de uma lanchonete local reservada para brancos e reivindicaram atendimento. O desafio lançado pelos jovens à ordem racista imposta pelas leis de segregação racial (Jim Crow) ganhou ampla repercussão nacional e a tática de ocupação empregada, denominada de sit-in, foi prontamente replicada em diversos pontos de todo o Sul. ${ }^{65}$ Em pouco tempo, o episódio em Greensboro deu origem a uma "onda" de protestos que se espalhou por mais de 70 comunidades sulistas, resultando em cerca de duas mil detenções de manifestantes. Segundo estimativas, um ano e meio depois o movimento teria envolvido um

divergiam da moderação política de grupos como a NAACP e a NUL (National Urban League) dedicados à transformação gradual da segregação racial pela via legal e educacional - ao defenderem o enfrentamento direto do racismo pelo emprego da ação direta: boicotes, Freedom Rides, sit-downs (modalidade que, nos anos 1960, seria denominada de sit-ins), dentre outros. Nas décadas de 1950 e 1960, o CORE desempenhou, juntamente ao SNCC, um papel central nas campanhas dos Direitos Civis no Sul, além de liderar as iniciativas contra segregação habitacional, escolar e trabalhista nos centros urbanos do Norte do país. MEIER, August; RUDWICK, Elliott. CORE. A Study in the Civil Rights Movement, 19421968. New York: Oxford University Press, 1973, p. 3-8.

${ }^{65}$ Sit-ins foram estratégias de manifestação que questionavam a segregação racial, especialmente sulista, nos espaços urbanos de convívio entre negros e brancos - lanchonetes, pontos de ônibus, estações de trens, dentre outros. Utilizadas por ativistas desde a Segunda Guerra Mundial, os sit-ins basicamente consistiam no ato de ocupar (sentar, do verbo em inglês sit) assentos, balcões e demais espaços destinados unicamente ao público branco. Em pouco tempo, variações dessa estratégia foram criadas pelos manifestantes dos Direitos Civis que ajoelhavam-se nos espaços segregados (kneel-in), entregavam-se à prisão durante protestos (jail-in), rezavam em igrejas segregadas (pray-in) e nadavam em praias e piscinas destinadas aos brancos (wade-ins). 
contingente impressionante de mais de 70 mil pessoas negras e brancas. ${ }^{66}$

Procurando fomentar a mobilização proporcionada pelos sit-ins bem como resguardá-la do controle que as lideranças religiosas do movimento buscavam exercer sobre os manifestantes, a ativista Ella Baker (1903-1986) da SCLC - Southern Christian Leadership Conference, convocou, em abril de 1960, na cidade de Raleigh, Carolina do Norte, uma convenção estudantil que redefiniu os rumos do movimento afro-americano daquela década. ${ }^{67}$ Veterana das lutas que reivindicavam direitos políticos dos negros desde a Grande Depressão, nos anos 1960, Baker já era então uma ativista influente com vasta experiência. Sua atuação remetia à organização comunitária no Harlem em finais dos anos 1930, passando pelo trabalho de supervisão de filiais da NAACP no Sul durante os anos 1940 e pela institucionalização, em 1957, da SCLC, entidade formada por pastores da Igreja Batista negra e presidida por Martin Luther King. Valendo-se de seus contatos na SCLC, a intervenção de Baker em Raleigh provou-se decisiva: ao final do encontro atendido por estudantes engajados nos sit-ins e por diversas organizações do período, o SNCC - Student Nonviolent Coordinating Committee foi criado. A partir de então, a agitação estudantil surgida de manifestações dispersas em prol da dessegregação de espaços públicos ganhou contornos de um movimento dedicado à realização de amplas reformas sociais. ${ }^{68}$

Oriundos da expressiva mobilização estudantil que sacudiu os estados sulistas, os fundadores do SNCC buscaram, desde o princípio, distingui-lo das organizações tradicionais dos Direitos Civis como a SCLC de Martin Luther King, a NAACP e a NUL - National Urban League. De maneira geral, a iniciativa refletia o anseio dos estudantes por uma organização cuja estrutura de funcionamento fosse mais democrática, menos hierarquizada, e mais "horizontal" em

${ }^{66}$ SITKOFF, Harvard. op. cit., p. 61-64.

${ }^{67}$ A SCLC foi uma das principais organizações surgidas a partir da ascensão do Movimento pelos Direitos Civis em meados da década de 1950. Fundada, naquela ocasião, por religiosos e pastores negros da Igreja Batista, a SCLC substituiu a MIA - Montgomery Improvement Association, entidade que coordenou o Boicote aos Ônibus de Montgomery e alçou Martin Luther King à cena pública nacional.

${ }^{68}$ Dentre os diversos grupos de ativismo negro presentes no encontro de fundação do SNCC estavam a já mencionada SCLC, o CORE e o FOR - Fellowship of Reconciliation, organização pacifista interracial da qual, nos anos 1940, Bayard Rustin fez parte. Em relação às organizações estudantis, estiveram presentes a NSA - National Student Association, uma confederação de diretórios universitários; a SDS - Students for a Democratic Society, importante organização de estudantes brancos universitários que, nos anos seguintes, estabeleceria fortes laços com o SNCC; e o grupo religioso da National Student Christian Federation. CARSON, Clayborne. In Struggle. SNCC and the Black Awakening of the 1960s. Harvard University Press, 1981, p. 19-21. Sobre a trajetória e atuação de Ella Baker, cf. RANSBY, Barbara. Ella Baker and the Black Freedom Movement. A Radical Democratic Vision. Chapel Hill \& London: The University of North Carolina Press, 2003. 
consonância com a espontaneidade e autonomia de ação demonstrada por eles durante os sit-ins. Orientados por Ella Baker, os participantes estabeleceram um Comitê temporário que cooperaria com as iniciativas do ativismo negro sulista, mas sem submeter-se oficialmente à hierarquia de comando dos grupos existentes. Com isso, concebiam o SNCC como uma organização independente que, pautada pelo debate e pela tomada coletiva de decisões, coordenasse as lutas estudantis locais contra a segregação racial. ${ }^{69}$

Nesse primeiro momento, um grupo de estudantes oriundos de Nashville, Tennessee, estabeleceu sua influência sobre o SNCC. Ancorado nas perspectivas ideológicas reformistas que orientavam as lideranças religiosas dos Direitos Civis desde a ascensão do movimento em meados da década de 1950, esse grupo subscrevia a uma visão de mundo humanista calcada nos princípios cristãos da Igreja Batista negra e no compromisso com a não-violência gandhiana. Tais perspectivas, expressas no documento fundacional da organização, constituíram o eixo ideológico central dos primeiros anos de funcionamento da organização:

"Afirmamos o ideal filosófico ou religioso da não-violência como o fundamento de nosso propósito, o pressuposto de nossa fé e o modo de nossa ação. A não violência, como originada a partir da tradição judaicocristã, busca uma ordem social de justiça permeada pelo amor. [...] Através da não-violência, a coragem substitui o medo; o amor transforma o ódio. A aceitação dissipa o preconceito; a esperança acaba com o desespero. A paz domina a guerra; a fé reconcilia a dúvida. $\mathrm{O}$ respeito mútuo cancela a inimizade. Justiça para todos derruba a injustiça. A comunidade redentora suplanta sistemas sociais brutalmente imorais. [...] Ao apelar à consciência e à posição sobre a natureza moral da existência humana, a não-violência nutre a atmosfera em que a reconciliação e a justiça se tornam possibilidades reais". ${ }^{70}$

Nesse sentido, embora o recém-formado SNCC fosse resultado de uma certa militância estudantil dedicada à ação direta não-violenta e aos princípios da democracia participativa -

${ }^{69}$ Cf. CARSON, Clayborne. op. cit., p. 19-30.

70 "We affirm the philosophical or religious ideal of nonviolence as the foundation of our purpose, the presupposition of our faith, and the manner of our action. Nonviolence as it grows from Judaic-Christian tradition seeks a social order of justice permeated by love. [...] Through nonviolence, courage displaces fear; love transforms hate. Acceptance dissipates prejudice; hope ends despair. Peace dominates war; faith reconciles doubt. Mutual regard cancels enmity. Justice for all overthrows injustice. The redemptive community supersedes systems of gross social immorality. [...] By appealing to conscience and standing on the moral nature of human existence, nonviolence nurtures the atmosphere in which reconciliation and justice become actual possibilities". In: CARSON, Clayborne. op. cit., p. 23-24. 
principalmente na forma de sit-ins, mas também através de boicotes, piquetes, protestos, dentre outros -, as perspectivas políticas de seus fundadores ancoravam-se, ainda, em valores liberais convencionais esposados pelas lideranças negras nacionais. Conforme destaca o historiador Clayborne Carson, grande parte dos estudantes dos sit-ins que deram origem ao SNCC aspiravam a um status de classe média que, em geral, não se contrapunha às instituições e aos valores hegemônicos da sociedade norte-americana. ${ }^{71}$

Em outras palavras, os estudantes em sua maioria concordavam com a concepção liberal vigente entre as lideranças negras do período que consideravam a segregação racial como um anacronismo a ser "corrigido", uma "incompatibilidade" com o credos fundadores da nação norte-americana, o chamado American Creed: os princípios constitucionais que previam a igualdade de todos homens, o direito inalienável à vida, liberdade e à busca da felicidade e um governo democrático com o consentimento popular. Nesse sentido, nos primeiros anos da década de 1960, os membros do SNCC eram reformistas - alguns mais militantes e outros menos - que aprovavam o caminho trilhado pelo ativismo negro da época nas lutas contra a segregação racial, manifestando-se contra o ritmo lento, o gradualismo, das mudanças obtidas mas não contra a direção em que seguiam. ${ }^{72}$ Em suma, a diferença, portanto, era que os jovens em torno do SNCC tinham pressa por resultados, queriam agir imediatamente e de maneira que as decisões fossem também discutidas entre eles.

Em alguns anos, a orientação cristã que conferia ao SNCC o senso de uma comunidade espiritual e fraterna entre ativistas negros e brancos - do qual advinha a caracterização do grupo como uma beloved community - começou a perder espaço para concepções mais pragmáticas de luta social que se fortaleciam na organização. A partir da segunda conferência do grupo, realizada em outubro de 1960, diversos estudantes do SNCC já inclinavam-se a outras atividades e preocupações para além dos sit-ins e da integração de espaços segregados. Nesse ponto, o NAG Nonviolent Action Group, coletivo de ativistas da Howard University filiado ao SNCC,

\footnotetext{
${ }^{71}$ Ibidem, p. 14.

${ }^{72}$ Conforme afirma o historiador Manning Marable, é importante ressaltar que, ao exporem os paradoxos dos valores nacionais em relação aos afro-americanos, os jovens ativistas - negros e brancos - não formulavam, naquele momento, uma perspectiva revolucionária, antagônica a estes valores. Na realidade, os sit-ins que buscavam o fim da segregação racial não representavam uma rejeição ao "Sonho Americano", mas colocavam-se como um caminho necessário à sua realização. Cf. MARABLE, Manning. Race, Reform, and Rebellion: The Second Reconstruction and Beyond in Black America, 1945-2006. 3. ed. Jackson: University Press of Mississippi, 2007, p. 63; GERSTLE, Gary. American Crucible: Race and Nation in the Twentieth Century. Princeton and Oxford: Princeton University Press, 2002, p. 4.
} 
desempenhou um importante papel de politização e formação intelectual de ativistas do movimento estudantil negro. ${ }^{73}$ A partir dele, Stokely Carmichael e outros estudantes da Howard University engajaram-se, definitivamente, no Movimento pelos Direitos Civis.

\subsubsection{Howard University: vida intelectual de Carmichael no campus}

Em visita à Washington durante seu último ano na Bronx High School of Science, Stokely conheceu um grupo de jovens manifestantes do NAG. Informando-o acerca de suas atividades políticas, os protestantes despertaram o interesse de Carmichael pela universidade e pelo movimento estudantil negro que ganhava corpo e repercussão através dos sit-ins. Assim, pouco depois de formar-se no ensino médio, Stokely participou de manifestações contra a segregação racial em Washington, no estado da Virginia, e matriculou-se na Howard University. ${ }^{74}$ Lá, Carmichael deparou-se com uma instituição de ensino superior de excelência, dotada de uma vida intelectual vibrante.

Historicamente negra, as origens da Howard University remontam à luta abolicionista do século XIX. Fundada em 1867, pouco após o fim da Guerra Civil (1861-1865) que consolidou a unidade nacional e encerrou a escravidão no país, a universidade serviu como sede do Freedmen's Bureau - agência do governo federal destinada ao auxílio à população negra liberta nos estados sulistas da Confederação - durante o período da Reconstrução. ${ }^{75}$ No século seguinte, a instituição passou por grandes transformações em paralelo à ascensão do New Negro Movement nas décadas de 1920 e 1930, contexto no qual conformou-se uma influente rede de intelectuais, artistas e ativistas afro-americanos em torno da universidade - alguns dos quais ainda lecionavam

\footnotetext{
${ }^{73}$ CARSON, Clayborne. op. cit., 29-30.

74 JOSEPH, Peniel E., op. cit., 2014. p. 23-24.

${ }^{75}$ A Reconstrução (1865-1877) compreendeu um período de tentativa de transformação dos estados e da sociedade sulista após a vitória da União na Guerra de Secessão. Empreendidas por uma maioria Republicana no Congresso norte-americano, tais mudanças previam, nos primeiros anos, garantir a obediência dos antigos estados Confederados ao governo federal e a assegurar o acesso da população liberta às prerrogativas de uma cidadania mínima. Dessa forma, três importantes emendas à Constituição foram aprovadas, Décima Terceira, Décima Quarta e Décima Quinta, visando a proteção desses direitos. Nesse breve contexto de avanços em prol da população afro-americana - logo removidos quando antigos confederados, líderes e políticos racistas retomaram o poder nos estados sulistas - diversas instituições de ensino superior foram criadas por missionários e expoentes do governo federal. Dentre elas, figurava a Howard University, universidade fundada por um general da União e financiada por verbas federais. Para um panorama histórico do período da Reconstrução, cf. FERNANDES, Luiz Estevam; MORAIS, Marcus Vinicius de. Os EUA no século XIX. In: KARNAL, Leandro; PURDY, Sean; FERNANDES, Luiz Estevam; MORAIS, Marcus Vinícius de. op. cit., p. 137-151.
} 
na instituição em 1960. Naquele período, lá atuaram importantes expoentes da intelligentsia negra como, por exemplo, Alain LeRoy Locke, tido como patrono e difusor do termo New Negro; E. Franklin Frazier, sociólogo e ativista próximo à NAACP; Ralph Bunche, cientista político ganhador do prêmio Nobel da Paz; e Carter G. Woodson, historiador pioneiro na institucionalização do estudo da história e cultura afro-americanas nos Estados Unidos. ${ }^{76}$

Localizada em um bairro negro a noroeste de Washington D.C., a vida acadêmica da Howard University inscrevia-se em um ambiente urbano dotado de grande efervescência social, cultural e política. Ao mesmo tempo que situava-se próxima da sede do governo federal, think tanks, instituições filantrópicas e embaixadas; a universidade gozava de uma comunidade multicultural composta por parcelas expressivas das classes médias da diáspora negra entre seus discentes e docentes. ${ }^{77}$ Assim, à época da chegada de Stokely Carmichael na instituição, para além da presença afro-americana maciça, a universidade contava com um significativo contingente de estudantes e acadêmicos africanos e caribenhos que contribuíam para a formação de uma comunidade acadêmica transnacional pujante. Ao longo de gerações, a rica história intelectual de Howard consolidou a imagem da instituição como uma "Meca" negra ou, como definiu Ta-Nehisi Coates, escritor e ex-aluno da instituição, uma "encruzilhada da diáspora", local de convergência das mais distintas culturas e representantes do Atlântico Negro. ${ }^{78}$

Embora a universidade abarcasse estratos relativamente privilegiados - e, não raro, conservadores - da população negra, a segregação racial também exercia grande impacto na vida acadêmica da instituição. Residentes em meio à comunidade negra local, alguns alunos, professores e até ex-diretores da instituição organizavam-se em redes de ativismo e sociabilidade intelectual ativas no combate ao Jim Crow. Vivenciada de perto, a segregação racial estendia-se, para eles, da vida social à acadêmica, conectando o pessoal ao profissional, a reflexão intelectual

\footnotetext{
${ }^{76}$ WILLIAMS, Zachery R. In Search of the Talented Tenth. Howard University Public Intellectuals and the Dilemmas of Race, 1926-1970. Columbia: University of Missouri Press, 2009. p. 11-13.

${ }^{77} \mathrm{Em}$ parte, isto se devia à procura crescente de africanos pelo acesso às instituições de ensino superior da Europa e Estados Unidos durante o pós-Guerra. Naquele período, à medida que o colonialismo no continente se afrouxava, um número crescente de jovens e intelectuais africanos realizavam este percurso que também atraiu figuras célebres como Léopold Sédar Senghor (um dos intelectuais fundadores do movimento literário da Nègritude e futuro presidente do Senegal), Chinua Achebe (consagrado romancista nigeriano) e, claro, Kwame Nkrumah. Anos depois, após as lutas por independência no continente, os intercâmbios transnacionais travados entre estes intelectuais negros da diáspora foram decisivos para a formação das bases políticas sobre as quais a militância pan-africanista - da qual Carmichael eventualmente faria parte - se assentaram. Sobre este percurso, cf. PARADA, Maurício et al. op.cit., p. 56.

${ }^{78}$ COATES, Ta-Nehisi. Entre o mundo e eu. Rio de Janeiro: Objetiva, 2015, 48-49.
} 
à prática política. ${ }^{79}$

Dessa maneira, muitos docentes que influenciaram a trajetória universitária de Stokely Carmichael eram intelectuais públicos que inspiravam-se no modelo do "acadêmico-ativista" (scholar-activist) representado por W.E.B. Du Bois, um dos intelectuais afro-americanos mais proeminentes da primeira metade do século. ${ }^{80}$ De fato, seja pelo perfil socioeconômico relativamente "elevado" de sua comunidade e/ou pelo compromisso público assumido pela sua intelligentsia, Howard constituía-se à imagem do talented tenth defendido por Du Bois. Isto é, a instituição adotava como "missão" preparar os(as) expoentes da elite intelectual e profissional negra - vistos, por alguns, como "homens e mulheres da raça" (race men and women) - aos(as) quais caberia o papel de liderar as "massas" afro-americanas na busca por avanços sociais e políticos para a população afro-americana. ${ }^{81}$

Imbuídos dessa "vocação" pelo engajamento político, diversos intelectuais da instituição estabeleciam redes de sociabilidade com um espectro político variado que incluía desde a alta cúpula governamental de Washington e alguns grupos dos Direitos Civis (em especial a NAACP e a NUL) até militantes proeminentes como os já mencionados Du Bois e Malcolm X. ${ }^{82}$ Portanto, através do contato e dos estudos realizados com aqueles professores, Carmichael pôde familiarizar-se com importantes referências intelectuais e políticas com as quais tivera um

\footnotetext{
${ }^{79}$ A este respeito é interessante ressaltar, por exemplo, que boa parte da equipe de advogados da NAACP atuando no caso de Brown vs. Board formou-se em Howard. Dentre eles, James Nabrit Jr., o reitor da instituição em exercício durante a graduação de Carmichael, fez parte daquela ofensiva legal. CARMICHAEL Stokely; THELWELL, E. M., op. cit., p. 116; WILLIAMS, Zachery R. op. cit., p. 82.

${ }^{80} \mathrm{O}$ "acadêmico-ativista" negro (scholar-activist) é definido por Zachery Williams como um intelectual dissidente, comprometido com o diálogo e a transformação política das comunidades negras nas quais se inseria. Nesta definição, portanto, o autor se aproxima da concepção de Edward Said que trata o intelectual como um outsider, um crítico que "fala a verdade ao poder". A esse respeito, cf. WILLIAMS, Zachery R. op.cit., p. 1-4; 11-20 e SAID, Edward. op. cit., 2005.

${ }^{81}$ Popularizado por Du Bois em um ensaio de sua autoria publicado em 1903, o termo talented tenth (algo como o "décimo talentoso", em português) expressava a crença do sociólogo no potencial transformador desempenhado pelo acesso dos negros ao ensino superior. Como indicado, o termo dizia respeito a uma elite afro-americana com formação universitária, "os dez por cento", vista pelo ativista como uma "vanguarda da raça" responsável por "elevar" as condições de vida da população negra ("os 90 por cento restantes") através de seus esforços e conquistas. Posteriormente, em meados da década de 1930, momento que marca a ruptura do sociólogo com a NAACP, Du Bois recuou em relação à proposição do talented tenth e passou a atribuir um papel político mais significativo às camadas populares afroamericanas na luta contra o racismo. DU BOIS, W.E.B. The Talented Tenth. In: WASHINGTON, Booker T. et al. The Negro Problem. A series of articles by representative Afro-American negroes of to-day. New York: James Pott \& Company, 1903 e WILLIAMS, Zachery R. op. cit., p. 17; 201.

${ }^{82}$ WILLIAMS, Zachery R. op.cit., p. 131-132.
} 
primeiro contato pouco antes nas ruas do Harlem. ${ }^{83}$

Dentre os diversos intelectuais da Howard University que participaram da formação de Stokely, E. Franklin Frazier desempenhou um importante papel na trajetória universitária do ativista. ${ }^{84}$ Renomado sociólogo negro e professor da instituição desde os anos 1930, Frazier era autor do célebre livro The Black Bourgeosie (1957) no qual teceu fortes críticas à acomodação política e ao conservadorismo moral das elites intelectuais e classes médias negras dos Estados Unidos. Engajado na NAACP e apoiador de longa data da luta por Direitos Civis, ele defendia que, embora desejável, a integração do negro na sociedade norte-americana branca não deveria ocorrer às custas do apagamento dos valores e da cultura afro-americanas. Ao contrário, a "assimilação" promovida por ele pautava-se pela valorização da identidade negra e pelo reconhecimento da história e cultura negras como parte constituintes do todo social mais amplo. ${ }^{85}$

As críticas do sociólogo direcionadas, amiúde, aos quadros intelectuais e burocráticos das universidades, aproximaram o professor dos estudantes-ativistas do NAG. Dessa forma, para Carmichael e seus colegas que iniciavam suas trajetórias de ativismo, Frazier, dentre outros docentes de Howard, figuravam como importantes referências de intelectuais negros que combinavam produção de conhecimento e engajamento nas pautas políticas concernentes à comunidade afro-americana. ${ }^{86} \mathrm{~A}$ partir dessas sociabilidades intelectuais firmadas em Howard junto ao NAG, Carmichael lançou-se firmemente à atividade política.

\subsubsection{Carmichael e o Nonviolent Action Group: primeiros passos no ativismo}

A introdução de Stokely Carmichael na vida política do campus e fora dele deu-se a partir

${ }^{83}$ CARMICHAEL Stokely; THELWELL, E. M., op. cit., p. 131. Acerca das referências intelectuais mencionadas, conferir a seção 1.2 acima.

${ }^{84}$ Além de Frazier, cabe mencionar também as influências de Toni Morrison e Sterling Brown em Carmichael. A primeira foi professora de inglês de Stokely em seu primeiro semestre na Howard University décadas antes de consolidar-se como a primeira escritora a vencer o prêmio Nobel de Literatura. Anos depois, Morrison trabalhou como editora de Black Power: The Politics of Liberation e Stokely Speaks: From Black Power to Pan-Africanism, obras de Carmichael publicadas pela Random House e analisadas por este trabalho. Brown, por sua vez, um poeta, historiador, crítico literário e folclorista, interessou-se particularmente pelo jovem Stokely e seu grupo de amigos do NAG convidandoos para encontros promovidos em sua casa onde discutiam literatura, poesia e crítica musical. Contando com uma vasta rede de contatos que incluíam músicos como o pianista Duke Ellington e o cantor e ativista Paul Robeson, Brown tornou-se uma importante referência cultural para Carmichael, mostrando-lhe, segundo lembraria décadas mais tarde, "como apreciar e amar a cultura do nosso povo". CARMICHAEL, Stokely; THELWELL, E. M., op. cit., p. 129-130; JOSEPH, Peniel E. op. cit, 2014, p. 26.

${ }^{85}$ WILLIAMS, Zachery R. op. cit., p. 182-186.

${ }^{86}$ Ibidem, p. 4. 
da sua entrada no NAG - Nonviolent Action Group durante o primeiro ano de graduação. Composto por cerca de cinquenta ativistas locais, em sua maioria estudantes da Howard University - dentre os quais cerca da metade eram mulheres e oito eram brancos - o grupo encontrava-se em reuniões que combinavam discussões teóricas com sessões de planejamento político. O NAG, segundo lembra Carmichael, “[...] estava lutando em pelo menos duas frentes muito diferentes: uma para mobilizar o campus e a outra para acabar com o racismo na nação". ${ }^{87}$

$\mathrm{Na}$ universidade, os membros do NAG colocavam-se como dissidentes políticos, opondose ao que consideravam ser um padrão de apatia e conservadorismo expresso por boa parte do corpo discente e pelos administradores da instituição, alguns dos quais eram por eles identificados como "Pais Tomás" (Uncle Toms), "acomodacionistas" nos moldes do já referido Booker T. Washington. Partindo deste pressuposto, o grupo buscava mobilizar os estudantes no campus e fora dele, envolvendo-os nas lutas nacionais contra a segregação racial realizadas localmente em Washington e nos estados de Maryland e Virginia. ${ }^{88}$

De maneira geral, em 1960 e parte de 1961, o ativismo de Carmichael e dos membros do NAG foi diretamente inspirado, como indicado, pelos sit-ins estudantis que originaram o SNCC. À semelhança deste, os membros do NAG pertenciam a um estrato estudantil, em sua maioria da classe média negra. Sua atuação também diferenciava-se da moderação política característica de organizações nacionais do movimento mencionadas como a NAACP, a NUL e a SCLC. Estas últimas, muito atuantes nos embates legais junto à Suprema Corte e na articulação de lobbys políticos e de financiamento para o Movimento, distinguiam-se dos estudantes cujo apreço pela ação direta - por meio de boicotes, sit-ins, piquetes, dentre outros - e pela democracia participativa conferia um aspecto em geral "mais combativo" à luta contra a segregação racial.

Assim como os estudantes dos sit-ins, os membros do NAG eram adeptos da desobediência civil não-violenta tida por eles como um recurso importante para a transformação social que almejavam. Além disso, compartilhavam da perspectiva reformista que orientava a luta estudantil e o Movimento pelos Direitos Civis como um todo contra a segregação racial. De

\footnotetext{
87 "It was immediately clear that the organization was struggling on at least two very different fronts: one to organize the campus, the other to end racism in the nation". CARMICHAEL, Stokely; THELWELL, E. M., op. cit., p. 138.

${ }^{88}$ No campus, o NAG vinculava-se à política estudantil nacional através da atuação em dois fronts: o jornal da universidade, o Hilltop, e o Conselho Estudantil, órgão que administrava recursos voltados aos estudantes e cuja liderança tinha participação na NSA - National Student Association. Ibidem, p. 138; $146 ; 149-151$.
} 
maneira geral, acreditavam, portanto, na capacidade do ativismo de transformar e expandir a "democracia norte-americana" através do engajamento do governo federal na proteção dos direitos constitucionais negados aos afro-americanos pelas leis Jim Crow. ${ }^{89}$

Contudo, não obstante o alinhamento à agenda política dos Direitos Civis, a inserção do NAG no ativismo negro estudantil da época também comportava algumas particularidades. Em primeiro lugar, diferentemente de boa parte dos estudantes que formaram o SNCC, alguns membros do NAG, como Carmichael, tendiam a enxergar a não-violência por uma ótica pragmática, encarando-a sobretudo como uma estratégia de ação política e não como uma "filosofia de vida" embasada em valores cristãos. ${ }^{90}$

Em parte, isso se devia à influência política exercida nos membros do grupo por Bayard Rustin, o já mencionado estrategista do movimento na prática da desobediência civil gandhiana. Nesse sentido, enquanto os estudantes presentes na fundação do SNCC consideravam Rustin um "radical" devido aos seus antigos vínculos com o CPUSA, os membros do NAG tinham-no como um mentor político central. ${ }^{91}$ Discutidos nos encontros do grupo, os escritos do ativista veterano instruíram Carmichael na teoria e nas técnicas da desobediência civil, perspectivas estas que conformaram a base de sua ação política nos primeiros anos do movimento. ${ }^{92}$

Por outro lado, o perfil intelectual do NAG também contribuía para a sua diferenciação

${ }^{89}$ JOSEPH, Peniel E., op. cit., 2014, p. 51-52.

${ }^{90}$ CARMICHAEL, Stokely; THELWELL, E. M., op. cit., p. 172-173.

${ }^{91}$ Nos anos 1960, Rustin reemergiu da sua trajetória pregressa no socialismo e pacifismo como um importante proponente de alianças políticas entre o ativismo negro, o Partido Democrata e movimentos trabalhistas. Em outubro de 1960, não obstante suas perspectivas políticas voltarem-se ao reformismo liberal e à não-violência, Rustin foi impedido de participar da segunda convenção do SNCC devido à pressão de grupos contrários à sua presença no encontro. Para além do rótulo de "radical" atribuído a ele graças às suas associações passadas com a Young Communist League - a ala jovem do CPUSA onde, como visto, Carmichael o conhecera - Bayard também foi marginalizado pelas lideranças nacionais do movimento negro por ser homossexual. Décadas mais tarde, durante os anos 1980, Rustin tornou-se um reconhecido ativista do movimento gay nos Estados Unidos. Sobre Rustin e a segunda convenção do SNCC, cf. CARSON, Clayborne. op. cit., p. 29. Para um panorama da trajetória deste ativista, cf. CARBADO, Devon W.; WEISE, Don. Introduction. In: Time on two crosses: The collected writings of Bayard Rustin. 2a ed. Cleis Press, 2015.

92 JOSEPH, Peniel. op. cit., 2014, p. 28. Em particular, conferir The Negro and Nonviolence e Nonviolence vs. Jim Crow, ensaios discutidos pelos jovens nas reuniões de formação política do NAG. No primeiro, datado de 1942, Rustin defendia a ação direta não violenta como o caminho a ser seguido pelo ativismo negro na luta contra a segregação racial. Para ele, a construção de um movimento de desobediência civil de massa no Sul poderia ocorrer - como, em parte, de fato ocorreu na década de 1950 - a partir da mobilização das redes de sociabilidade afro-americanas centradas nas Igrejas Batistas Negras. Nonviolence vs. Jim Crow, por outro lado, um relato da recusa de Rustin em obedecer leis segregacionistas nos anos 1940, configurava uma exemplo para os membros do NAG visualizarem a aplicação prática da filosofia defendida pelo autor. CARBADO, Devon W.; WEISE, Don. op. cit., 2015. 
em relação ao estudantes que protagonizaram os sit-ins da época. Para além do enfoque dedicado à integração de espaços públicos e à realização de reformas em prol dos Direitos Civis dos negros, o grupo incentivava a conscientização do corpo discente da Howard University em torno das questões políticas, econômicas e sociais concernentes à população afro-americana. Por meio do Project Awareness, programa que sediava debates acerca de "temas controversos" do período, Carmichael e seus colegas do NAG desempenharam um papel importante para a formação política - e, eventualmente, a radicalização - de estudantes da Howard University que adensaram os quadros do SNCC. ${ }^{93}$

Como primeira atividade, o Project Awareness sediou, em finais de 1961, um célebre debate entre Bayard Rustin e Malcolm X que repercutiu nacionalmente através de importantes jornais da imprensa negra como o Baltimore Afro-American e o Chicago Defender. ${ }^{94} \mathrm{O}$ evento, cuja realização foi negociada por Frazier junto às autoridades do campus, constituiu uma experiência marcante da trajetória universitária de Carmichael. Intitulado "Integração ou Separação", o debate representava, para Stokely e seus colegas do NAG incumbidos de dar as boas-vindas ao líder da Nação do Islã, uma aguardada oportunidade de testarem os princípios que embasavam a sua própria atuação política no Movimento. Neste aspecto, Malcolm, à época um reconhecido expoente do nacionalismo negro e ferrenho opositor do projeto integracionista capitaneado por Martin Luther King, representava para os estudantes tanto um contraponto político-ideológico quanto um modelo radical de intelectual publicamente comprometido com a defesa da dignidade e autodeterminação negras.

Valendo-se da atenção comandada pela sua presença, Malcolm dirigia-se à Howard como parte de um tour por diversas instituições de ensino superior. A princípio, tais compromissos buscavam divulgar a mensagem da Nação do Islã - as ideias de Elijah Muhammad - a fim de contestar distorções acerca do grupo e dos seus princípios. No entanto, o militante também possuía uma agenda própria. Para ele, o distanciamento da Nação do Islã em relação aos debates políticos da época representava um grave erro de cálculo político que prejudicava a força da

\footnotetext{
${ }^{93}$ Segundo Carson, o NAG foi pioneiro na discussão de programas de natureza econômica dentro do SNCC - até então voltado majoritariamente à dessegregação de espaços públicos - a partir das atividades promovidas por meio do Project Awareness. Assim, para além do debate com Malcolm e Rustin, Carmichael e o NAG sediaram, também, debates com o socialista Norman Thomas e o historiador comunista Herbert Aptheker. CARSON, Clayborne. op. cit., p. 103-104.

${ }^{94}$ JOSEPH, Peniel E. op. cit., 2014, p. 42.
} 
organização frente as críticas que recebia. ${ }^{95}$

Portanto, ao invés de abster-se do confronto de perspectivas, durante o debate Malcolm X empenhou-se em atacar a análise liberal e integracionista acerca das relações raciais em uma tentativa de dividir a opinião da audiência branca e negra e, com isto, conquistar adeptos para a organização. Reivindicando o lugar de fala do gueto urbano, o militante mobilizou o argumento de Frazier - moderador do evento - no livro Black Bourgeoisie ao afirmar que as lideranças integracionistas da classe média afro-americana não se comprometiam a melhorar a vida dos negros mais pobres. Sujeitos à violência policial, pobreza e segregação urbana; os afroamericanos mais pobres, argumentou Malcolm, encontrariam apoio não na busca pela assimilação racial à sociedade branca, mas pela separação - cultural, econômica, espacial - desta, conforme defendido pela Nação do Islã. ${ }^{96}$

Rustin, por sua vez, saiu em defesa do integracionismo, criticando o separatismo de Malcolm como impreciso e impraticável sem conseguir, contudo, a mesma resposta da audiência obtida pelo seu adversário. Embora, como mencionado, o intelectual veterano figurasse como uma referência central aos estudantes do NAG ali presentes, a oratória envolvente de Malcolm X representava uma novidade. Através de suas críticas ao racismo e à "democracia" norteamericana, Malcolm personificava uma militância radical não encontrada pelos estudantes nos líderes dos Direitos Civis. Em poucos anos, o apelo do porta-voz da Nação do Islã informaria as perspectivas políticas de diversos estudantes que, como Carmichael, iniciavam suas trajetórias de ativismo para além dos muros da universidade. ${ }^{97}$

\footnotetext{
${ }^{95}$ MARABLE, Manning. Malcolm X: Uma Vida de Reinvenções. Companhia das Letras, 2013, p. 211.

${ }^{96}$ Ibidem, p. 211-215.

97 JOSEPH, Peniel E. op. cit., p. 53. Em pouco tempo, os ativistas dos Direitos Civis lidariam com as críticas lançadas por Malcolm X aos princípios que norteavam sua atuação - em particular, a integração do negro na sociedade mais ampla por via da ação direta não-violenta. Para Carmichael, nos anos seguintes, estes questionamentos tomaram forma como resultado das dificuldades e violências vivenciadas por ele como voluntário nos projetos do SNCC no Mississippi, discutidos nas seções à frente.
} 


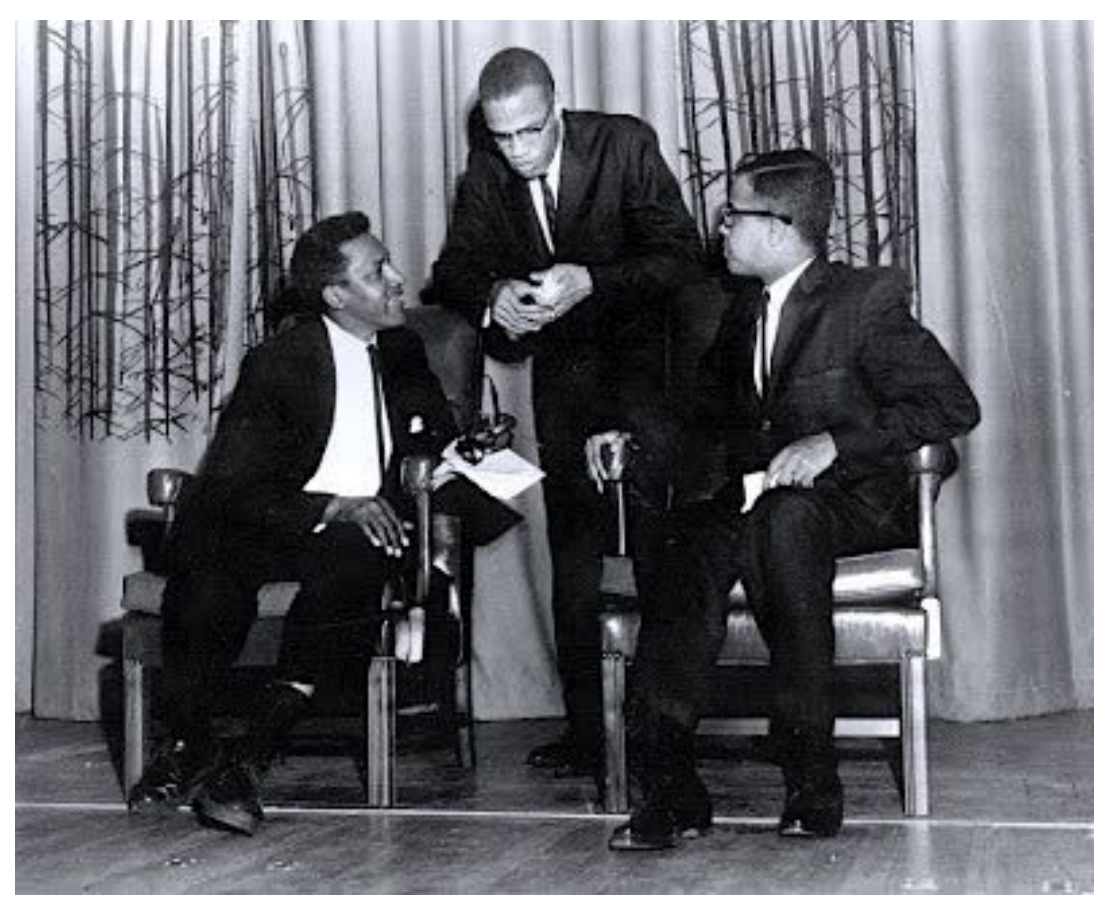

Imagem 1 - Bayard Rustin e Malcolm X (à esquerda e no centro, respectivamente) se reúnem para o debate "Integração ou Separação" organizado por Stokely Carmichael e os membros do NAG na Howard University. Fonte: <http://thehilltoponline.com/2016/05/19/the-hilltop-archives-1961-malcolm-X-at-themecca/>. Acesso em: 29 de agosto de 2017.

Naquele momento, a Howard University e o NAG - Nonviolent Action Group representaram os primeiros espaços de sociabilização intelectual e política de Stokely Carmichael a partir dos quais ele ingressou nas campanhas de ativismo promovidas pelo CORE e pelo SNCC em distintos pontos do Sul do país na primeira metade da década de $1960{ }^{98}$ Nesse processo, iniciado pelo envolvimento de sua geração com os sit-ins, Carmichael presenciou a intransigência do racismo sulista bem como a condescendência do governo federal com o Jim Crow. Estas experiências, aliadas à frustração com a moderação política das lideranças negras nacionais, informaram a radicalização de suas perspectivas políticas que levaram, na segunda metade da década, ao seu rompimento com o Movimento pelos Direitos Civis.

\footnotetext{
${ }^{98}$ Assim como Carmichael, diversos dos seus colegas do NAG também seguiram o caminho do ativismo junto ao SNCC. Dentre eles, cabe mencionar os ativistas Michael Ekwueme Thelwell e Cleveland Sellers pela sua relevância na trajetória de Carmichael. Ambos foram membros do SNCC durante anos, sendo que Thelwell - editor do Hilltop, jornal estudantil da universidade ao qual Carmichael contribuía com artigos sobre as campanhas dos Direitos Civis no Sul - chegou à direção da filial do grupo em Washington enquanto Sellers esteve com Stokely quando da adesão do SNCC ao Black Power. Além disso, Thelwell é co-autor de Ready for Revolution, a autobiografia de Carmichael concebida nos últimos anos de vida deste e publicada postumamente.
} 


\subsection{A "linha de frente" dos Direitos Civis: Carmichael nas campanhas do SNCC contra a segregação racial}

"Nós aprendemos muito em Howard: este era o nosso laboratório. Aprendemos ainda mais no NAG: este foi o nosso treinamento in loco. Mas o Mississippi foi minha educação real e o SNCC minha alma mater. [...] O Mississippi me ensinou pela primeira vez a dor e a alegria da luta. Ele cristalizou minha política, abriu meus olhos e me ensinou a organizar politicamente". 99

A partir de 1961, o movimento dos sit-ins que, no ano anterior, havia originado o SNCC, dividiu-se em duas iniciativas desenvolvidas pelos ativistas do grupo em diversos pontos do Sul dos Estados Unidos: a ação direta e o registro eleitoral de afro-americanos excluídos do acesso ao pleito. Tais estratégias, empregadas em grande parte junto às comunidades negras rurais, conformaram a base do ativismo de Stokely Carmichael e dos seus colegas do NAG dentro e fora dos muros da Howard University. Assim, nos anos subsequentes, Carmichael dedicou boa parte da sua atuação política aos projetos desenvolvidos pelo CORE e, principalmente, à iniciativas voltadas à dessegregação racial e ao registro eleitoral de afro-americanos desenvolvidas pelo SNCC no Mississippi.

\subsubsection{Freedom Rides}

Iniciadas em maio de 1961, as Freedom Rides revitalizaram o protesto estudantil após o esfriamento dos sit-ins, conferindo aos ativistas um novo senso de militância e engajamento. Idealizadas originalmente pelo CORE nos anos 1940, essas campanhas consistiam em viagens interestaduais de ônibus realizadas por grupos interraciais de ativistas que percorriam o Sul dos Estados Unidos. Valendo-se do recurso à ação direta não-violenta, os viajantes buscavam testar a aplicação das determinações da Suprema Corte no caso de Boynton vs. Virginia (1960) que proibiam a discriminação racial em ônibus e terminais de transportes públicos sulistas. ${ }^{100}$

Para os ativistas participantes como Carmichael, as Freedom Rides apresentaram-se como oportunidades singulares para pressionar um governo federal inativo a intervir em prol dos

\footnotetext{
99 "We had been learning a lot at Howard: that was our laboratory. We learned even more in NAG: that was our on-the-job training. But Mississippi was my real education and SNCC my alma mater. [...] Mississippi first taught me the pain and the joy of struggle. It crystallized my politics, opened up my eyes, and taught me how to organize". CARMICHAEL Stokely; THELWELL, E. M., op. cit., p. 277.

${ }^{100}$ SITKOFF, Harvard. op. cit., p. 88-89.
} 
objetivos do Movimento pelos Direitos Civis. Até então relutante em contrariar os segregacionistas do Partido Democrata que compunham a base aliada do seu governo, com as Freedom Rides, o presidente John F. Kennedy viu-se forçado a enviar tropas federais dada a repercussão nacional e internacional alcançada pela escalada da violência racista contra os viajantes. Nesse sentido, a "timidez" demonstrada por Kennedy - para quem a preocupação com a "unidade nacional" norte-americana frente à "ameaça comunista" durante a Guerra Fria sobrepunha-se à urgência das demandas por Direitos Civis - em relação à proteção dos ativistas do CORE e do SNCC contribuiu para reforçar as críticas lançadas ao seu governo por ativistas que engajaram-se nas viagens. ${ }^{101}$

Carmichael, naquele momento um primeiranista na Howard University, acompanhou a primeira leva de Freedom Rides através dos noticiários nacionais que reportavam a violência com a qual os ônibus dos estudantes foram recebidos nas cidades de Anniston e Birmingham, no estado do Alabama. Em uma segunda leva, organizada por Diane Nash, ativista do "grupo de Nashville" diretamente ligado à fundação do SNCC, Stokely e vários outros colegas do NAG viajaram para desafiar a segregação racial nas estações de trem de Nova Orleans e da cidade de Jackson, Mississippi. Nesta última, o grupo foi preso e encaminhado para a notória penitenciária Parchman Farm, onde boa parte ficou detida por quarenta dias à mercê da brutalidade do sistema prisional do estado. Carmichael - que passou seu aniversário de vinte anos na prisão - e muitos outros colegas foram mantidos em confinamento e sujeitos a agressões constantes às quais respondiam cantando músicas de protesto e realizando greves de fome. ${ }^{102}$

\footnotetext{
${ }^{101}$ Ibidem, p. 95-98.

102 JOSEPH, p. 31-34. Denominadas freedom songs pelos ativistas, as músicas de protesto do Movimento pelos Direitos Civis remetiam à religiosidade da cultura e da música popular (folk music) negras sulistas. Cantadas em Igrejas Batistas, marchas, prisões, sit-ins, freedom rides, etc; estas canções faziam parte do cotidiano do ativismo e constituíam "hinos" utilizados no movimento tanto para convocar à ação quanto para promover a união e fortalecer o moral em momentos de crise.
} 


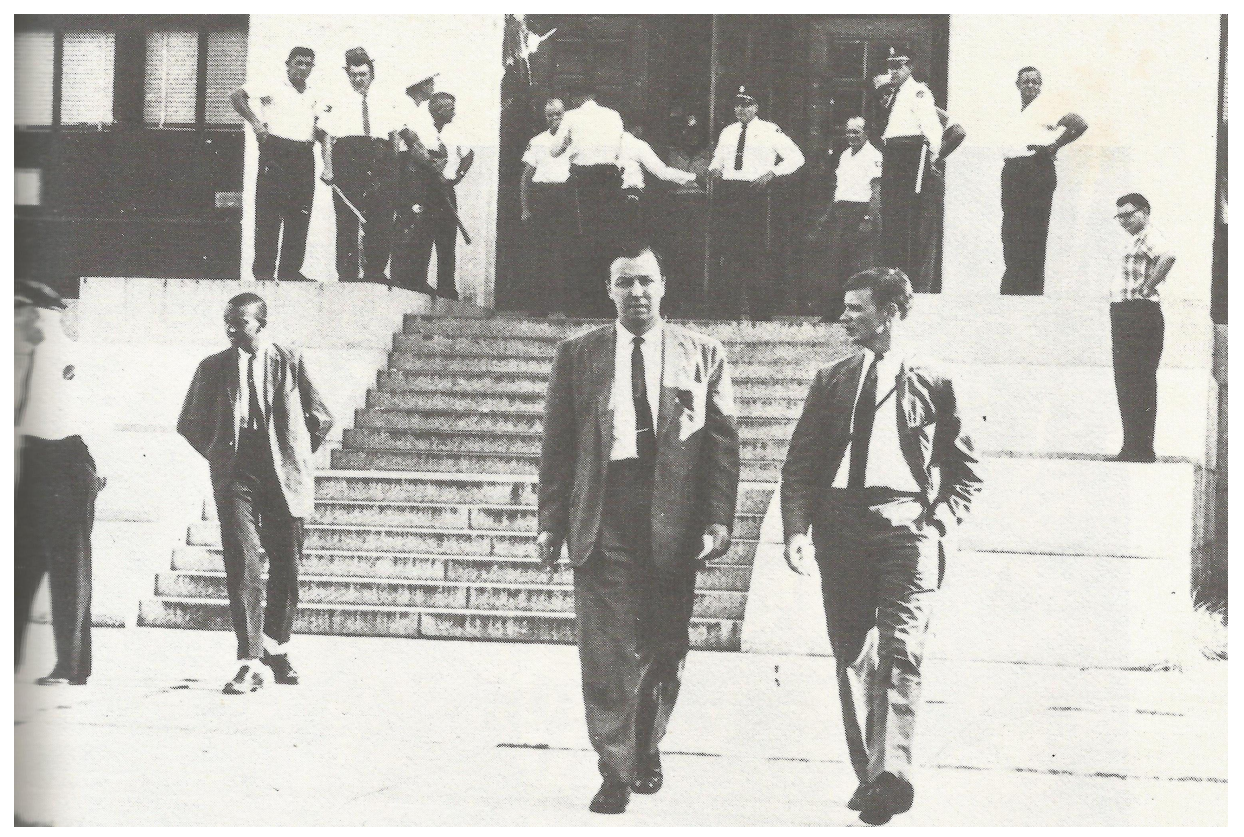

Imagem 2 - Stokely Carmichael (ao fundo e à esquerda) saindo do tribunal de Jackson, Mississippi, após ser detido por participar das Freedom Rides de 1961. Fonte: CARSON, Clayborne. op. cit., p. 82-83.

Portanto, as Freedom Rides e as prisões de seus voluntários foram decisivas para a conformação de uma identidade militante entre membros do SNCC que até então encontravamse dispersos e incertos quanto ao papel que desempenhariam dentro do Movimento pelos Direitos Civis. A partir dessas experiências, Carmichael e muitos outros estudantes intensificaram o seu compromisso com o ativismo negro, ocupando-se de outras pautas políticas para além da dessegregação dos espaços públicos. ${ }^{103}$

\subsubsection{Campanhas pelo registro eleitoral de afro-americanos no Mississippi}

Em particular, essa ampliação do ativismo de Stokely Carmichael ocorreu pela participação nas campanhas de registro eleitoral iniciadas pelo SNCC em 1961 no estado do Mississippi. Naquele ano, na cidade de McComb, ativistas do grupo que buscavam garantir o acesso da população negra local ao pleito foram duramente atacados por segregacionistas e não puderam dar continuidade às suas atividades. Na ocasião, a repressão racista que pôs fim ao projeto em McComb contribuiu para tornar o SNCC mais dissidente e combativo, informando a postura cada vez mais crítica que assumiam em relação aos valores de classe média presentes no

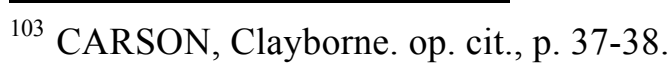


grupo desde os sit-ins. ${ }^{104}$

Dessa maneira, a campanha de McComb era indicativa da militância de ativistas do SNCC que, como Stokely Carmichael, comprometeram-se a desafiar a segregação racial no Mississippi, estado infame pelo histórico de violência racial infringida à população negra. A esse respeito, desde finais do século XIX, durante a reação sulista que sucedeu o período da Reconstrução, o Mississippi notabilizara-se ao liderar as iniciativas dos estados escravocratas do chamado "Sul Profundo" (Deep South) - Alabama, Mississippi, Georgia, Lousiana, Carolina do Sul, em geral - voltadas ao cerceamento dos direitos políticos e das garantias constitucionais adquiridas pelos afro-americanos após o fim da Guerra Civil. ${ }^{105}$

A partir daquele momento, concentrados no Partido Democrata, os segregacionistas da região instituíram uma série de provisões nas constituições estaduais com o objetivo de barrar os afro-americanos de se registrarem como eleitores e exercerem o voto. Recorrendo a estratégias que incluíam desde cobranças de taxas para o registro eleitoral, passando pela exigência de testes de alfabetização e de "interpretação" da Constituição até o emprego de represálias econômicas e da violência física; as autoridades brancas lograram restringir a participação política negra a um mínimo. Dessa forma, enquanto nas cidades sulistas alguns poucos afro-americanos profissionais de classe média, em geral - conseguiram superar as barreiras impostas pelos brancos, nas áreas rurais praticamente nenhum negro votava, mesmo em condados nos quais constituíam maioria numérica. Assim, em 1961, à época da chegada dos ativistas do SNCC, somente cerca de sete por cento dos afro-americanos do estado eram eleitores registrados. Destes, pouquíssimos se arriscavam a votar temendo serem alvo de retaliações racistas como demissões, expulsões das terras nas quais trabalhavam e até linchamentos. ${ }^{106}$

Naquele momento, a vivência nos rincões sulistas intocados pelas lideranças nacionais do movimento foi determinante para ampliar as perspectivas e expectativas de Stokely Carmichael acerca da luta por Direitos Civis. O confronto entre seu ativismo inicial - pautado pelos sit-ins e pela influência política exercida por Bayard Rustin no NAG - e suas experiências posteriores na "linha de frente" do movimento no Mississippi, orientavam-no para uma perspectiva de luta social mais inclusiva, construída com a participação direta das camadas mais pobres das

${ }^{104}$ CARSON, Clayborne. op. cit, p. 54-55.

105 KEYSSAR, Alexander. The Right to Vote. The Contested History of Democracy in the United States. Basic Books, 2000, p. 110-116. Sobre a Reconstrução, cf. nota 47 no item 1.3.2.

${ }^{106}$ KEYSSAR, Alexander. op. cit., p. 110-116; 258-259. Dados sobre o Mississippi disponíveis em: $<$ http://www.crmvet.org/info/voter_ms.pdf>. Acesso em: 30 de agosto de 2017. 
comunidades negras sulistas: os trabalhadores rurais. Neste ponto, Carmichael inspirava-se nos ensinamentos de Ella Baker, figura central para a formação política dos ativistas do SNCC para quem a luta contra a segregação racial não poderia prescindir da participação popular de massa nos processos decisórios do movimento.

É importante destacarmos aqui que, como exemplificado por Ella Baker, a participação de mulheres negras foi fundamental para a consolidação da luta por direitos civis como um movimento de massas de alcance nacional. Embora muito frequentemente a historiografia do tema - em especial a das décadas de 1960 e 1970 - tenha negligenciado o seu papel em prol da atenção dedicada às lideranças masculinas, o envolvimento do ativismo feminino na organização política das comunidades sulistas precedeu e coexistiu com a ascensão do movimento negro à cena pública nacional. Em sua maioria, aponta a socióloga Belinda Robnett, as mulheres afroamericanas atuavam como "líderes intermediárias" engajadas nas comunidades negras sulistas. Dessa forma, conquanto excluídas dos principais cargos das organizações dos Direitos Civis, a sua atuação em escala "micro" se revelava essencial à articulação entre as pautas comunitárias locais e a agenda política nacional do movimento negro. ${ }^{107}$

Assim, em consonância com o que propunha Baker, Carmichael e os outros membros do grupo investiam em um longo e árduo trabalho de base, cotidiano, voltado à organização política comunitária, cujo objetivo maior residia em contribuir à formação de lideranças locais para a luta contra o racismo. Tal perspectiva evidenciava o caráter democrático e humanista da filosofia política e da visão de mundo de Baker adotada por Carmichael durante o seu trabalho com o SNCC: práticas e contextos opressivos deveriam ser integralmente transformados, revertidos a uma condição de equilíbrio democrático por meio da deliberação constante e da construção coletiva de consensos entre os envolvidos. Para isso, fazia-se necessário valorizar a contribuição, dignidade e a liderança de cada indivíduo - independentemente do nível de instrução ou posição social - na construção dos caminhos a serem trilhados pelo movimento. ${ }^{108}$

Filiado a essas perspectivas, Carmichael passou seguidas férias escolares trabalhando como voluntário nos projetos desenvolvidos pelos SNCC. Nos verões de 1962 e 1963, o ativista de vinte e dois anos mudou-se para a cidade de Greenwood, no delta do Mississippi, onde residiu

\footnotetext{
${ }^{107}$ ROBNETT, Belinda. African-American Women in the Civil Rights Movement, 1954-65: Gender, Leadership, and Micromobilization. American Journal of Sociology, v. 101, n. 6, mai. 1996, p. 1661-1693.

${ }^{108}$ Sobre as perspectivas de Ella Baker que orientaram os ativistas do SNCC, cf. RANSBY, Barbara. op. cit., p. 24; 269-271; 368-370.
} 
em meio a comunidade rural negra contribuindo para organizá-la em torno da reivindicação pelo direito do voto. Por meio do contato com lideranças locais - frequentemente expoentes religiosos e/ou sujeitos cujo envolvimento com o dia-a-dia local precedia a chegada das organizações dos Direitos Civis - os voluntários familiarizavam-se com as dificuldades vivenciadas pelas comunidades e estabeleciam a confiança necessária à sua mobilização pelo direito à representatividade política. Para tanto, combinavam sessões de formação e engajamento político - visitando afro-americanos residentes em plantações de algodão, oferecendo aulas coletivas e orientações para o registro eleitoral - com uma imersão na vida cotidiana da região - indo às celebrações religiosas nas igrejas negras, trabalhando no campo, partilhando refeições, dentre outros. $^{109}$

\subsubsection{Engajamento político em Washington e Maryland}

Paralelamente ao trabalho no Mississippi, entre 1961 e 1964, Stokely Carmichael também engajou-se nas imediações da Howard University, lutando contra a discriminação racial em Maryland, estado localizado na divisa entre o Norte e o Sul dos Estados Unidos. Nestas ocasiões, a atuação de Carmichael nas cidades de Washington, Cambridge e Baltimore constituía um exemplo claro de que a luta pelos Direitos Civis dos afro-americanos conformou um movimento nacional contra a discriminação racial que ultrapassava os estados do já mencionado "Sul Profundo" e envolvia diversas cidades do Norte, do Meio-Oeste e da Costa Oeste do país.

Nesse sentido, é importante ressaltarmos que, embora não fosse estipulada pela legislação como ocorria nos estados sulistas, a segregação racial se fazia presente no restante do país através da imposição de diversos padrões discriminatórios aos afro-americanos nas áreas educacionais, residencial e no mercado de trabalho. Reagindo a isso, em cidades do Meio-Oeste e do Norte como Chicago, Boston e Nova York, por exemplo, ativistas filiados ao CORE e à NAACP mobilizaram, entre as décadas de 1950 e 1970, milhares de pais e alunos a organizarem boicotes como forma de pressão contra a precariedade das instalações e da qualidade de ensino das escolas públicas que atendiam a população negra. Também na Costa Oeste, em grandes centros como Seattle e Los Angeles, ativistas locais manifestavam contra a segregação racial do espaço urbano

\footnotetext{
${ }^{109}$ Para um panorama das relações estabelecidas entre os ativistas do SNCC e as comunidades negras do interior do Mississippi, cf. PAYNE, Charles M. Slow and respectful work: organizers and organizing. In:_. I've got the light of freedom. The organizing tradition and the Mississippi freedom struggle. Berkeley and Los Angeles: University of California Press, 2007, pp. 236-264.
} 
resultante de práticas excludentes empregadas pelo mercado imobiliário com a anuência do poder público. $^{110}$

De toda forma, em Maryland, as atividades políticas de Carmichael renderam-lhe numerosas prisões, um padrão que se tornava cada vez mais frequente na trajetória do ativista. Em outubro de 1961, por exemplo, no momento em que Malcolm X fazia sua controversa visita à universidade, Stokely e outros membros do NAG foram detidos por coordenar sit-ins e piquetes na cidade de Baltimore e em restaurantes segregados da Rota 40, principal via de acesso à capital do país. Dois anos depois, no primeiro semestre de 1963, Carmichael denunciou a construção do novo ginásio esportivo da instituição pelo emprego de mão-de-obra segregada. O caso ganhou ampla repercussão midiática no campus e entre a burocracia política de Washington uma vez que a obra era financiada pelo governo federal por meio de uma licitação pública. Representando o NAG, o jovem ativista depôs à Comissão de Direitos Civis - órgão governamental criado em 1957 para investigar práticas raciais discriminatórias nas atividades desenvolvidas pelo Estado norte-americano - reafirmando a denúncia do grupo contra as exclusões promovidas pelos sindicatos encarregados das contratações de funcionários. ${ }^{111}$

Por último, no primeiro semestre de 1964, Carmichael juntou-se ao NAG para protestar em Cambridge, Maryland, uma pequena cidade próxima a Washington cuja população negra sofria com altos índices de desemprego, carência habitacional e desigualdade de ensino. Mesmo após longa mobilização e intensos confrontos que forçaram o presidente Kennedy a convocar a Guarda Nacional, as autoridades municipais de Cambridge recusaram-se a atender as demandas das lideranças negras locais. Em meio a estas tensões, Stokely e o NAG engajaram-se na organização de uma marcha na cidade em resposta à visita de George Wallace, notório político segregacionista do Alabama e candidato às primárias presidenciais do Partido Democrata em 1964. Duramente reprimida pela Guarda Nacional, a manifestação terminou com a hospitalização e a subsequente detenção de Carmichael. ${ }^{112}$

Dessa maneira, fosse na Howard University, no Mississippi ou em Cambridge, Maryland, a atuação política de Carmichael combinava ação direta e organização política comunitária na

\footnotetext{
${ }^{110}$ Para uma discussão cuidadosa acerca das lutas desenvolvidas nestas regiões durante o Movimento pelos Direitos Civis, cf. THEOHARIS, Jeanne; WOODARD, Komozi (orgs.). Freedom North. Black Freedom Struggles outside the South. New York: Palgrave Macmillan, 2003 e SUGRUE, Thomas. Sweet Land of Liberty. The Forgotten Struggle of Civil Rights in the North. New York: Random House, 2009.

${ }^{111}$ JOSEPH, Peniel E. op. cit., 2014, p. 43-44; 50-53.

${ }^{112}$ CARMICHAEL Stokely; THELWELL, E. M., op. cit., p. 337-346.
} 
luta contra a discriminação racial presente na sociedade norte-americana. Portanto, como observado, Stokely e o SNCC pautavam-se por uma perspectiva reformista engajada não apenas com as demandas pelo acesso à cidadania plena negada aos afro-americanos - isto é, à sua “integração" legal à sociedade mais ampla - mas também cada vez mais comprometida com a justiça social e a igualdade econômica para os negros. ${ }^{113}$

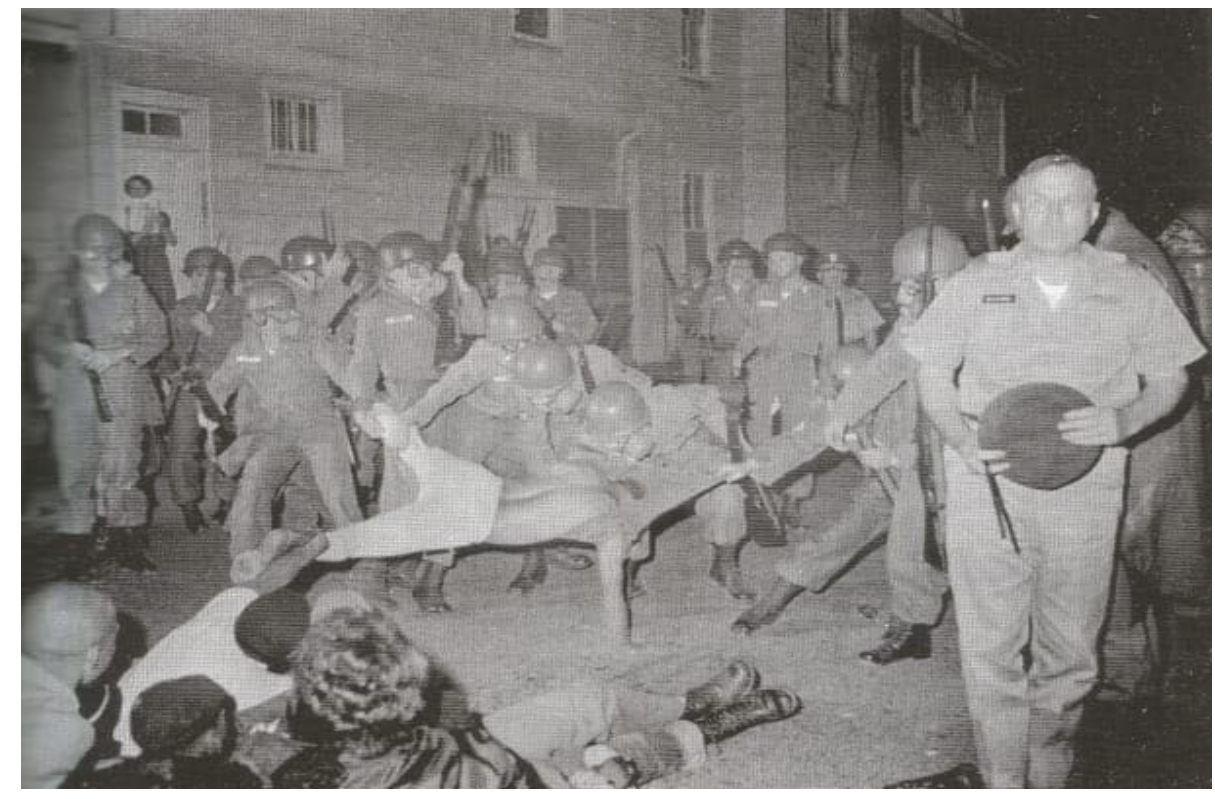

Imagem 3 - Carmichael (embaixo à esquerda, segurando a perna do ativista sendo agredido) na manifestação em Cambridge, Maryland, 1964. Fonte: CARMICHAEL Stokely; THELWELL, E. M., op. cit., p. 500-501.

Ademais, ao filiar-se à visão de democracia participativa esposada pelo SNCC, o ativista contestava a concentração do poder decisório do movimento nas mãos das lideranças negras nacionais. Portanto, Carmichael e boa parte dos membros do SNCC eram críticos da moderação política por trás do modus operandi - construção de lobbys políticos, investidas legais, concessões ao Partido Democrata, captação de recursos e financiamento para o movimento praticado por grupos como a SCLC (Southern Christian Leadership Conference) e, em particular, organizações nacionais como a NAACP (National Association for the Advancement of Colored People) e a NUL (National Urban League).

Naquele momento, o engajamento de Carmichael em Maryland e no Mississippi inseriase em uma ofensiva maior orquestrada pelas lideranças do Movimento que culminou na ${ }^{113}$ JOSEPH, Peniel E. op. cit., 2014, p. 51-52. 
proposição de um projeto de Lei dos Direitos Civis pelo presidente John F. Kennedy em junho de 1963. ${ }^{114}$ Buscando pressionar o Congresso norte-americano a aprovar a medida, o que ocorreria somente no ano seguinte, uma coalizão de organizações dos Direitos Civis reformulou a Marcha Sobre Washington por Trabalho e Liberdade, iniciativa originalmente concebida pelo exsocialista e líder sindical negro A. Philip Randolph em princípio da década de 1940. Repercutindo nacional e internacionalmente, a manifestação reuniu cerca de 250 mil pessoas na capital do país em defesa de direitos civis e econômicos para a população afro-americana. ${ }^{115}$

Por um lado, a Marcha tem sido amplamente caracterizada como o "ápice” do Movimento pelos Direitos Civis, momento no qual Martin Luther King magnetizou a multidão presente no Lincoln Memorial com o seu célebre discurso I Have a Dream ("Eu Tenho Um Sonho"). Na ocasião, destaca o historiador Gary Gerstle, o "sonho" vislumbrado por King retirava sua força da crença na identidade, na simbologia, mitos e valores fundacionais da nação norte-americana; isto é, de um arraigado nacionalismo cívico (American Creed). Em outras palavras, King valia-se de uma poderosa habilidade retórica para articular a narrativa da nação norte-americana em favor do projeto de integração e igualdade social para os negros. ${ }^{116}$

Por outro, já em sua organização, a Marcha comportava divisões entre essa visão do Sonho Americano (American Dream) mobilizado pelas lideranças tradicionais dos Direitos Civis e aquela esposada pelos ativistas do SNCC. Tais fissuras no interior do movimento, expostas durante o evento pela censura do discurso "militante" do presidente do grupo, John Lewis, indicavam a radicalização política iniciada pelo ativismo estudantil, tido, pelas lideranças negras

${ }^{114}$ Com o assassinato de Kennedy em novembro de 1963, a Lei dos Direitos Civis (Civil Rights Act) foi ratificada somente em 1964, durante o mandato do seu sucessor, o presidente Lyndon Baines Johnson. Considerada um marco do Movimento pelos Direitos Civis, a medida estabelecia o fim da segregação racial ao proibir a discriminação contra afro-americanos no emprego, na educação e em espaços públicos. ISSERMAN, Maurice; KAZIN, Michael. America Divided: The Civil War of the 1960s. Oxford University Press, 2000, p. 106.

${ }^{115}$ MARABLE, Manning. op. cit., p. 70-72.

${ }^{116}$ Cabe salientarmos que, conquanto acreditasse no American Creed e defendesse a integração dos negros na sociedade norte-americana, Martin Luther King também articulava críticas importantes aos Estados Unidos. Na ocasião da Marcha, contudo, temendo alienar o apoio à luta por direitos civis concedido por liberais brancos e prejudicar a aprovação da legislação proposta pelo governo Kennedy, King ajustou seu discurso a uma audiência nacional e politicamente diversa. No entanto, nos anos seguintes, à medida que o ativismo negro se radicalizava, veremos que o pastor batista tornou-se um importante crítico da política externa dos Estados Unidos - particularmente em relação à Guerra do Vietnã - e da exploração econômica imposta aos afro-americanos. GERSTLE, Gary. American Crucible: Race and Nation in the Twentieth Century. Princeton and Oxford: Princeton University Press, 2002, p. 273-274. Sobre a narrativa da nação norte-americana, cf. JUNQUEIRA, Mary A. Estados Unidos. Estado Nacional e Narrativa da Nação (1776-1900). São Paulo: Edusp, 2018, p. 50-53. 
moderadas, como o "enfant terrible" do movimento. Para Carmichael e o SNCC, esse processo acentuou-se, de fato, em 1964, a partir do Freedom Summer e do desafio à delegação segregacionista do Partido Democrata lançada por ativistas do Mississippi. Naquele contexto, como veremos, a coalizão entre as organizações dos Direitos Civis começou a ruir à medida que os mais militantes do SNCC afastavam-se do nacionalismo cívico e do liberalismo político até então característicos da luta negra pela cidadania plena. ${ }^{117}$

\subsection{A desilusão de Carmichael com o Governo Federal e o Partido Democrata (1964)}

Em 1964, aos vinte e três anos de idade, Stokely Carmichael dedicou seu último ano na universidade ao trabalho como um organizador comunitário local no Mississippi. Em um curto intervalo de tempo, ele transformou-se de um estudante universitário em Howard para um ativista em tempo integral cooperando diretamente com Martin Luther King, Bayard Rustin e outras lideranças nacionais do movimento negro. ${ }^{118}$ Nestas ocasiões, informado pelos riscos e frustrações experimentadas pelo SNCC no Mississippi, Carmichael contestou e, depois, rompeu os laços firmados com a política reformista e integracionista dos Direitos Civis.

\subsubsection{Freedom Summer}

No verão de 1964, o ativista dirigiu uma seção do Mississippi Freedom Summer, projeto coordenado pelo COFO - Council of Federated Organizations, uma coalizão das principais organizações dos Direitos Civis capitaneadas pelo SNCC. Concebido no final do ano anterior, o projeto recrutou centenas de voluntários, em sua maioria estudantes universitários brancos vindos do norte do país, para atuar em Freedom Schools e fomentar uma grande campanha de registro eleitoral da população negra no Mississippi. ${ }^{119}$ Com isso, Bob Moses, ativista veterano do SNCC e diretor-geral do Freedom Summer, visava, à maneira das Freedom Rides nos anos anteriores, criar uma situação de crise entre os níveis estadual e federal de governo. No processo, objetivava

${ }_{117}^{117}$ GERSTLE, Gary. op. cit., p. 285-286.

118 JOSEPH, Peniel E. op. cit., 2014, p. 63.

119 Freedom schools consistiam em programas de educação informal voltados à alfabetização e conscientização política de populações negras desenvolvidos no Sul rural dos Estados Unidos. Durante o Freedom Summer, a iniciativa, ponto de encontro entre ativistas do SNCC, voluntários nortistas e a população local; oferecia uma formação básica acerca de temas concernentes ao movimento, à história afro-americana e à cidadania, assuntos estes inexistentes nas precárias escolas segregadas destinadas à população negra do Mississippi. 
atrair a atenção midiática para as violências perpetradas pelos supremacistas brancos e, dessa maneira, forçar uma intervenção federal contundente no estado que defendesse os direitos de sua população negra. $^{120}$

Amplamente debatida entre as lideranças, a proposta sofreu resistência especialmente entre membros do SNCC - dentre eles Carmichael - que consideravam o trabalho comunitário realizado majoritariamente por ativistas negros como parte essencial da identidade da organização. ${ }^{121}$ Dessa forma, a entrada de voluntários brancos rapidamente gerou tensões entre setores do grupo divididos entre a afirmação do protagonismo político negro na luta contra a segregação e a identificação com o ideal da beloved community, a mencionada irmandade interracial de ativistas, princípio que vinha orientando o SNCC desde sua fundação em $1960{ }^{122}$

Assim, embora de maneira geral compreendessem as implicações estratégicas do Freedom Summer, alguns membros do SNCC, particularmente os mais jovens, temiam a influência que a entrada maciça de voluntários brancos exerceria na luta por Direitos Civis como um todo. Estas disputas entre as partes, presentes desde a concepção do projeto, foram agravadas a partir da atenção diferenciada dedicada pelo governo federal e pela mídia nacional aos voluntários brancos. Exemplo disto, no início do mês de junho, o assassinato de três ativistas no condado de Neshoba - dentre os quais dois eram brancos - ganhou manchetes pelo país resultando em rápida resposta pelo $\mathrm{FBI}$ que conduziu investigações requisitadas pelo procurador geral dos Estados Unidos, Robert F. Kennedy. Ao fim da operação, os corpos foram encontrados e, diferentemente de numerosas ocasiões em que ativistas negros foram alvos de violência no Sul, as autoridades prenderam e indiciaram vinte e um envolvidos com o crime.

Na ocasião e durante todo o verão, lideranças do SNCC reagiram denunciando a "atenção seletiva" do governo federal e o seu descompromisso com a segurança dos ativistas. John Lewis, por exemplo, expressou o ressentimento de boa parte da militância do SNCC ao declarar que era uma "vergonha que o interesse nacional tenha despertado somente depois que dois garotos brancos desapareceram". O ativista ainda acrescentou que, se não fosse "providenciada proteção para os defensores dos direitos civis no estado, [...] seu sangue estará nas mãos do governo". ${ }^{23}$ Carmichael, que participou das buscas do SNCC pelos desaparecidos, também manifestou a sua

\footnotetext{
${ }^{120}$ CARSON, Clayborne. op. cit., p. 96.

121 CARMICHAEL Stokely; THELWELL, E. M., op. cit., p. 349.

122 CARSON, Clayborne. op. cit., p. 96-103.

${ }^{123}$ Ibidem, p. 115.
} 
indignação em um encontro entre os voluntários ao reconhecer a hipocrisia das autoridades que motivara o recrutamento de estudantes nortistas ao Summer Project:

"Enquanto essas pessoas estiverem aqui, a atenção nacional estará aqui. $\mathrm{O}$ FBI não vai deixar que nada aconteça com eles. Eles deixaram os assassinos de negros livres, mas homens foram presos em Itta Bena [pequena cidade do condado de Leflore, no Mississippi] apenas por ameaçar vidas brancas". 124

Embora repercutida pela mídia, a presença maciça de agentes federais no Mississippi para as buscas pelos assassinos não teve continuidade. Não obstante as reivindicações de longa data do SNCC para que o governo federal interviesse em prol da segurança e dos direitos dos afroamericanos no estado, casos de violência continuaram a surgir durante o verão, limitando, por um lado, o sucesso do Summer Project. Nesse sentido, o historiador Manning Marable estima que, durante o projeto, cerca de mil manifestantes foram presos por autoridades locais, 30 edifícios sofreram atentados a bomba, seis pessoas foram mortas e 36 igrejas negras foram queimadas. Dado o nível da violência e intimidação racistas, apenas cerca 1600 afro-americanos haviam se registrado como eleitores em todo o estado. ${ }^{125}$

Por outro lado, os ativistas conseguiram dar visibilidade nacional à brutal discriminação racial inflingida aos negros no Mississippi, além de contribuir à transformação dos quadros do ativismo estudantil negro e branco que, durante o verão, participaram das Freedom Schools e das campanhas de registro eleitoral. A esse respeito, após o Freedom Summer, enquanto diversos voluntários do Norte do país retornaram para casa e ingressaram nas organizações e movimentos da Nova Esquerda branca norte-americana como a SDS - Students for a Democratic Society, ativistas do SNCC reformulavam e radicalizavam suas perspectivas políticas. ${ }^{126}$

\footnotetext{
124 "While these people are here, national attention is here. The FBI isn't going to let anything happen to them. They let murderers of Negroes go off, but already men have been arrested in Itta Bena just for threatening white lives". JOSEPH, Peniel E. op. cit., 2014, p. 70.

${ }^{125}$ SITKOFF, Harvard. op. cit., p. 166-167; MARABLE, Manning. op. cit., p. 80.

${ }^{126}$ CARSON, Clayborne. op. cit., 128-129. A Nova Esquerda surgiu em meados da década de 1950 e consolidou-se nos anos 1960 como uma amálgama muito diversa de movimentos sociais - marcadamente estudantis - que buscavam uma interpretação mais humanista do marxismo, alternativa à ortodoxia stalinista da dita "Velha Esquerda" e à ênfase desta na organização do operariado industrial como forma privilegiada de transformação social. Nos Estados Unidos, a conformação da Nova Esquerda estudantil foi profundamente influenciada pela mobilização política trazida à tona pelos movimento dos Direitos Civis, Black Power e de resistência à Guerra do Vietnã. SOUSA, Rodrigo Farias de. A Nova Esquerda Americana: De Port Huron aos Weathermen (1960-1969). Rio de Janeiro: Editora FGV, 2009, p. 16-19.
} 


\subsubsection{Atlantic City e a ruptura com o establishment Democrata}

A radicalização política de Carmichael e de boa parte do SNCC foi profundamente marcada pela desilusão com o sistema político-partidário norte-americano após nova tentativa do ativismo negro do Mississippi de obter reconhecimento político junto ao Partido Democrata. ${ }^{127}$ Naquele ano, atentos às barreiras que ainda impediam o acesso dos afro-americanos à participação e à candidatura política no estado, ativistas do COFO formaram uma organização interracial independente dedicada a desafiar a delegação "regular" do Mississippi na convenção nacional do Partido Democrata em Atlantic City, New Jersey.

No entanto, em finais de agosto de 1964, capitalizando na cobertura midiática destinada à convenção que confirmaria Lyndon B. Johnson como candidato à presidência do país, o grupo, intitulado MFDP - Mississippi Freedom Democratic Party, teve seus esforços frustrados pela recusa do establishment Democrata de substituir a delegação segregacionista do estado pelos seus representantes. Em troca, por meio de um acordo de bastidores negociado junto a lobistas Democratas no Congresso (como o advogado membro da NAACP Joseph Rauh Jr.), líderes sindicais (Walter Reuther da UAW - United Automobile Workers, representante dos trabalhadores da indústria automobilística) e às lideranças nacionais dos Direitos Civis (dentre elas, Martin Luther King, Bayard Rustin e Roy Wilkins da NAACP), a candidatura de Johnson prometeu proibir a presença de delegações segregadas somente a partir da convenção seguinte, em 1968. Em 1964, contudo, somente dois delegados do MFDP seriam aceitos. ${ }^{128}$

A opção de Lyndon Johnson por resguardar o apoio das delegações sulistas à sua candidatura em detrimento da representatividade demandada pelo MFDP indignou Stokely Carmichael e dezenas de membros do SNCC presentes em Atlantic City. Recusado pelos ativistas, o acordo aprofundou as tensões entre a militância estudantil e os expoentes dos Direitos Civis vinculados à política liberal do Partido Democrata. Para Carmichael e outros discípulos de

${ }^{127}$ JOSEPH, Peniel E. op. cit., 2014, p. 75.

128 Aliados de peso de Rustin e de A. Philip Randolph, Rauh Jr. e Reuther eram lideranças cuja longa trajetória política remontava aos anos 1930 e aos princípios liberais do New Deal criado durante a presidência de Franklin Delano Roosevelt (1933-1945). Alinhados com as reformas nas relações raciais pretendidas pelos Direitos Civis, ambos acreditavam que o Estado deveria legislar e regulamentar o mercado a fim de gerar empregos e assegurar o poder de compra dos trabalhadores (negros, inclusive). Dada a sua influência junto ao Congresso nacional e ao alto escalão do Partido Democrata, Reuther e Rauh Jr. participaram ativamente na negociação e organização da emblemática Marcha Sobre Washington por Trabalho e Liberdade, de 1963, ao lado de representantes dos Direitos Civis da NAACP, NUL e SCLC. GERSTLE, Gary. op. cit., p. 278-279; 289-293. 
Bayard Rustin ligados à Howard University, a defesa do acordo realizada pelo mentor veterano foi percebida como uma "traição" àqueles que, durante todo o verão, arriscaram a vida lutando pelos direitos políticos dos afro-americanos no Mississippi. ${ }^{129}$

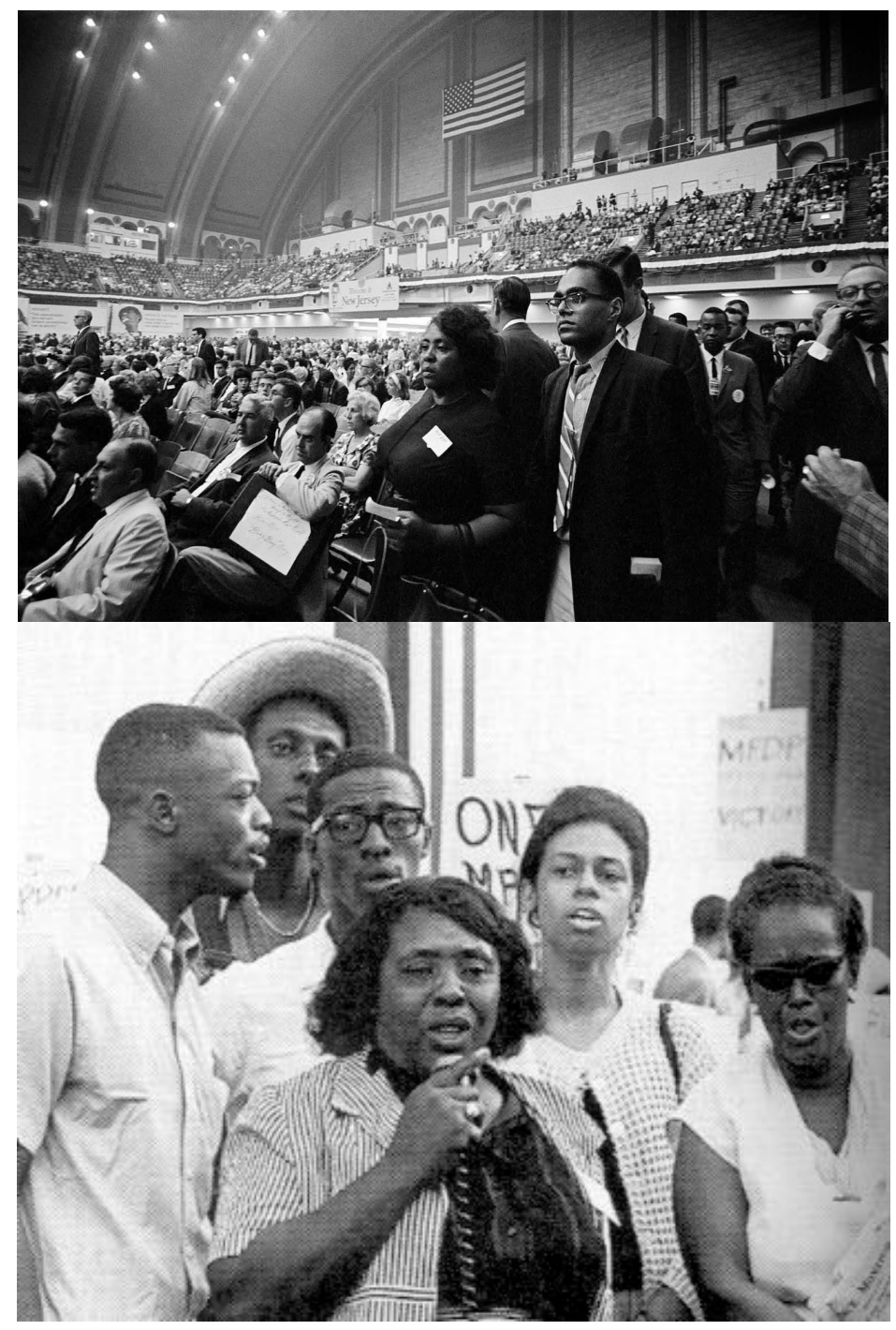

Imagens 4 e 5 - Na primeira imagem, Fannie Lou Hamer, liderança rural do Mississippi e delegada do MFDP, e o ativista do SNCC Bob Moses presentes na Convenção Nacional do Partido Democrata de 1964, em Atlantic City, New Jersey. Abaixo, Carmichael (de chapéu, ao fundo) participa de um comício do MFDP com Hamer e Ella Baker (última à direita). Fontes: fotografia da Convenção Democrata de autoria de George Ballis. In: KELLEN, Leslie (ed.). This Light of Ours. Activist photographers of the Civil Rights Movement. Jackson: University Press of Mississippi, 2011, p. 88. Imagem de comício do MFDP disponível em: <http://www.crmvet.org/images/imgfs.htm>. Acesso em: 28 de agosto de 2017.

${ }^{129}$ CARSON, Clayborne. op cit., p. 125-129; JOSEPH, Peniel E. op. cit., 2014, p. 76-77. 
Assim, para Stokely Carmichael e muitos outros, as experiências desses primeiros anos de ativismo, trouxeram à tona uma profunda descrença nas instituições, valores e promessas norteamericanas que pautavam o nacionalismo cívico do Movimento pelos Direitos Civis. Momentos importantes da trajetória do ativista, o Freedom Summer e o engajamento no MFDP revelaram-se centrais para o desencanto com a política reformista e de coalizão firmada pelas lideranças do movimento negro com setores Democratas e trabalhistas liberais. Revoltado com a relutância do establishment político em garantir a segurança e atender às reivindicações do ativismo negro sulista, Carmichael voltou-se, então, à política negra independente, alternativa à estrutura político-partidária (branca) em vigência na máquina do Partido Democrata. Como veremos nos próximos capítulos, uma vez consumada a ruptura com o modus operandi dos Direitos Civis, Carmichael e o SNCC caminharam progressivamente em direção à proposição de uma nova agenda política para o ativismo negro nos Estados Unidos: o Black Power. 


\section{CAPÍTULO 2 - A radicalização política de Stokely Carmichael e a ascensão do Movimento Black Power nos Estados Unidos (1965-1966)}

Como discutimos no capítulo anterior, a trajetória inicial de Stokely Carmichael foi atravessada por importantes rupturas e deslocamentos: fruto da diáspora negra e do colonialismo inglês no Caribe, Carmichael formou-se politicamente em meio ao "despertar" da luta pelos Direitos Civis nos Estados Unidos. Nos anos 1960, a inserção do ativista nesse movimento deu-se através do SNCC - Student Nonviolent Coordinating Committee, organização estudantil atuante na mobilização ativa das comunidades rurais sulistas em prol da dessegregação dos espaços públicos e da conquista de direitos políticos e econômicos para os afro-americanos. Portanto, observamos que, ao buscar o acesso dos negros à cidadania plena por meio da desobediência civil não-violenta, Carmichael e o SNCC vinculavam-se a um projeto reformista que almejava a integração dos negros na sociedade norte-americana sem recusar, ainda, a identidade nacional e os valores cívicos que norteavam as lideranças dos Direitos Civis e seus aliados liberais.

Neste capítulo, veremos como, no curto intervalo entre os anos de 1965 e 1966, essas perspectivas começaram a mudar. Para tanto, abordaremos o processo de radicalização atravessado por Stokely Carmichael e pela militância do SNCC a partir da experiência traumática em Atlantic City que culminou, em meados de 1966, na ascensão do Movimento Black Power à cena pública nacional. Em primeiro lugar, acompanharemos as transformações políticas atravessadas pelo ativista e pelo grupo na sequência do Freedom Summer, dando destaque ao seu envolvimento com o ativismo negro em Lowndes County, no estado do Alabama, a partir de 1965. Experiência marcante para Carmichael, o engajamento na região sinalizava a busca da militância do SNCC por uma política e identidade negras cada vez mais assertivas e autônomas em relação ao Partido Democrata e aos seus aliados. Dedicando-se à luta por representatividade e controle político negro nas comunidades rurais do condado de Lowndes, o ativista esboçava as linhas gerais do que constituiria o projeto político do SNCC durante os anos do Movimento Black Power.

Por último, veremos que, após a enunciação do Black Power por Stokely Carmichael em junho de 1966, a repercussão nacional alcançada por essa nova "palavra de ordem" introduzida pela militância foi tremenda e dividiu opiniões. Conquanto ainda carecesse de formulação, o Black Power surgia, tanto na imprensa liberal quanto no seio do movimento pelos Direitos Civis, 
como uma grande "polêmica", um prenúncio da profunda fragmentação e radicalização pela qual atravessariam o movimento negro e o país nos anos finais da década de 1960.

\subsection{Carmichael, o SNCC e a busca por novos caminhos para o ativismo negro}

O Freedom Summer e o MFDP - Mississippi Freedom Democratic Party impactaram profundamente Carmichael e os militantes do SNCC. O grupo, até então marcado por uma relativa unidade e familiaridade entre seus membros (a já mencionada beloved community), presenciou a transformação dos seus quadros com o influxo maciço de voluntários durante o verão de 1964. Terminado o Summer Project, muitos dos "nortistas" brancos remanescentes solicitaram admissão permanente à organização, o que, se efetivado, implicaria alterações drásticas na sua composição. Neste contexto, exauridos pelo trabalho no Mississippi e pressionados por tensões internas que ameaçavam dispersar o SNCC, Carmichael e os demais membros buscavam por novas diretrizes políticas que recuperassem uma certa coesão programática à organização. ${ }^{130}$

Em novembro de 1964, portanto, o SNCC sediou um retiro em Waveland, Mississippi, com o intuito de reparar a desorganização institucional que afetava seus projetos no Sul e estabelecer planos para novas atividades. $\mathrm{O}$ encontro, contudo, trouxe à tona os embates que, à época, já dividiam a base do SNCC em torno de questões como a presença de ativistas brancos na organização, a discriminação de gênero, o papel das mulheres dentro do movimento e a relação do grupo com a democracia participativa - isto é, entre a ênfase, por um lado, na autonomia de decisão dos ativistas e das lideranças comunitárias e, por outro, na defesa por mais centralização de planejamento.

Amplamente debatidos, esses temas sinalizavam as transformações políticas vivenciadas por Stokely Carmichael e os ativistas do SNCC em meados da década que culminaram, cerca de um ano depois, na proposição do Black Power como a agenda programática do grupo. Por outro lado, como aponta o historiador Clayborne Carson, tais embates indicavam também a importância do grupo para a conformação das pautas e dos movimentos sociais que orientavam o ativismo político da Nova Esquerda norte-americana em finais da década. Em especial, a consolidação de agendas feministas e feministas negras a partir de 1968 foi particularmente

${ }^{130}$ CARSON, Clayborne. In Struggle. SNCC and the Black Awakening of the 1960s. Harvard University Press, 1981, p. 133-134; JOSEPH, Peniel E. Stokely: A Life. New York: Basic Civitas, 2014, p. 79. 
devedora da formação política obtida por ativistas do SNCC nos movimentos pelos Direitos Civis e, posteriormente, no Black Power. ${ }^{131}$

Em suma, tendo reavaliado internamente suas atividades, conquistas e frustrações pregressas no âmbito dos Direitos Civis durante o encontro em Waveland, os(as) ativistas do SNCC lançaram-se a novas iniciativas informados(as) por um cenário político que se acirrava rapidamente. Exemplo disso, em fevereiro de 1965 um duro golpe foi dado no movimento negro: Malcolm X foi assassinado durante um comício da Organização para a Unidade Afro-Americana (OAAU - Organization of Afro-American Unity), grupo político pan-africanista fundado pelo militante após retornar de uma peregrinação religiosa à Meca e de passagens pela África, França e Inglaterra.

Cerca de um ano antes, Malcolm havia rompido com a Nação do Islã em decorrência de divergências com o dogmatismo político e religioso da cúpula da organização - principalmente com o seu líder, Elijah Muhammad, que restringia as atividades políticas de X. Após a ruptura, a influência crescente de Malcolm no cenário doméstico e internacional intensificou as tensões com lideranças da Nação do Islã existentes desde o envolvimento do militante na divulgação dos casos extraconjugais que Muhammad mantinha com secretárias do grupo - fato este que representava uma séria violação da conduta ética pregada pela organização. A partir de então, após encabeçar uma campanha de difamação contra Malcolm nas páginas do Muhammad Speaks, o jornal do grupo, setores da Nação do Islã começaram a planejar o assassinato do ex-membro com o intuito de "silenciá-lo". ${ }^{132}$

A morte de Malcolm, o principal expoente do nacionalismo negro nos Estados Unidos, representou um choque para membros do SNCC como Stokely Carmichael que reconheciam nele uma referência cada vez mais próxima aos seus anseios políticos no movimento negro. Não por acaso, na sequência do enorme sucesso alcançado pela publicação póstuma da autobiografia de X em 1965, o militante seria recuperado pela geração de Stokely como um "patrono", um ícone in

${ }^{131}$ CARSON, Clayborne. op. cit., p. 140-141; 153-154. Sobre a conformação de perspectivas feministas negras entre as ativistas do SNCC, cf. ANDERSON-BRICKER, Kristin. "Triple Jeopardy": black women and the growth of feminist consciousness in SNCC, 1964-1975. In: SPRINGER, Kimberly (org.). Still lifting, still climbing. African American women's contemporary activism. New York and London: New York University Press, 1999, p. 49-69.

${ }^{132}$ Sobre o assassinato de Malcolm X, cf. MARABLE, Manning. Malcolm X: Uma Vida de Reinvenções. Companhia das Letras, 2013, p. 9-23; 465-498 
absentia durante o Movimento Black Power. ${ }^{133}$

Em meados da década de sessenta, portanto, ao passo que Carmichael e parte do SNCC refletiam sobre sua atuação e perspectivas desde o episódio de Atlantic City, novas oportunidades de retorno à organização comunitária surgiam motivadas pela incursão do movimento negro no estado do Alabama. Naquele momento, na sequência da morte de Malcolm X, a cidade de Selma vivia dias de intensos protestos em decorrência de outro assassinato. Desta vez, a morte de um jovem afro-americano, vítima da violência policial durante uma manifestação pelo direito de voto organizada pela SCLC - Southern Christian Leadership Conference, precipitou a cooperação entre os líderes religiosos desta organização e o SNCC na concepção de uma sequência de marchas entre Selma e a cidade de Montgomery. Importante marco da luta afro-americana pelo acesso ao pleito, as manifestações no Alabama geraram grande repercussão na imprensa nacional devido à violência com a qual foram reprimidas pelo xerife segregacionista Jim Clark. Com isso, desempenharam um papel decisivo para influenciar a opinião pública e pressionar o presidente Lyndon Johnson e o Congresso norte-americano a aprovarem a Lei do Direito de Voto em agosto daquele mesmo ano. ${ }^{134}$

À semelhança da Lei dos Direitos Civis sancionada no ano anterior, a nova medida terminou por representar uma grande conquista para os ativistas do Movimento pelos Direitos Civis ao estabelecer o fim de diversas barreiras empregadas pelos segregacionistas do Sul para impedir o acesso dos afro-americanos ao pleito. ${ }^{135}$ Em linhas gerais, a lei proibiu as cobranças de taxas para o registro eleitoral da população negra, a imposição de testes de alfabetização e de exames "de conhecimento" da Constituição, o emprego de provisões subjetivas como a “avaliação do caráter" dos requerentes, dentre outros. Ademais, a legislação autorizou o envio de oficiais federais (federal registrars) para diversos estados Sulistas a fim de supervisionar a

${ }^{133}$ Sobre o impacto da morte de Malcolm X em Carmichael e os membros do SNCC, cf. CARMICHAEL, Stokely; THELWELL, Ekwueme M. op. cit., p. 428; 440-441; e CARSON, Clayborne. op. cit., p. 135136. Para a autobiografia, cf. X, Malcolm; HALEY, Alex. The Autobiography of Malcolm X. As told to Alex Haley. New York: Ballantine Books, 2015.

${ }^{134}$ MARABLE, Manning. Race, Reform, and Rebellion: The Second Reconstruction and Beyond in Black America, 1945-2006. 3. ed. Jackson: University Press of Mississippi, 2007, p. 77-79.

${ }^{135}$ Para além das mencionadas Leis dos Direitos Civis (1964) e do Direito de Voto (1965), outras medidas legais da segunda metade da década de 1960 constituíram importantes conquistas para as reivindicações do Movimento pelos Direitos Civis. Dentre elas, cabe destacar o caso Loving vs. Virginia (1967) no qual a Suprema Corte decidiu pela derrubada das interdições estaduais aos casamentos interraciais e o Fair Housing Act (1968), assinado por Lyndon Johnson após o assassinato de Martin Luther King, que proibia a discriminação racial no mercado imobiliário. 
observância destas medidas. Isso foi essencial para que, em estados fortemente segregados como o Mississippi e o Alabama, o número de eleitores afro-americanos registrados passasse por um aumento significativo entre 1964 e 1968: de 10 a 60 por cento no primeiro e, no segundo, de 24 a 57 por cento. ${ }^{136}$

No entanto, embora bem-sucedida em promover seus objetivos, a campanha em Selma foi atravessada por fortes tensões entre as partes envolvidas e, a princípio, contou com a oposição de Stokely Carmichael e de boa parte do SNCC. Atuantes na região antes da chegada da SCLC, os membros do SNCC opunham-se à repercussão midiática dedicada às lideranças negras nacionais recém-chegadas, pois consideravam isto um empecilho ao trabalho de base desenvolvido por eles localmente. Nesse ponto, ressaltou Carmichael, os atritos originavam-se de concepções distintas acerca do papel que a militância do movimento deveria desempenhar:

"[...] nós não teríamos problemas para trabalhar com a SCLC se sua abordagem fosse compatível com os valores do SNCC. [...] O problema estava no foco da SCLC na mobilização maciça, temporária e voltada à imprensa, em contraposição à criação de comunidades organizadas capazes de sustentar a luta política. [...] O SNCC vinha contínua e propositadamente desenvolvendo a base já presente em Selma. [...] Aí veio a SCLC falando em mobilizar mais uma campanha de duas semanas, usando nossa base e o nome mágico do Dr. [Martin Luther] King. Eles traziam as câmeras, a mídia, personalidades influentes, políticos e coisa e tal, viravam o lugar de cabeça para baixo e depois iam embora. [...] Esta foi a questão: uma verdadeira diferença estratégica e filosófica [entre o SNCC e a SCLC]". 137

Nas manifestações de Selma, assim como ocorrido na Marcha Sobre Washington e no caso do MFDP - Mississippi Freedom Democratic Party no ano anterior, King e a SCLC

${ }^{136}$ KEYSSAR, Alexander. The Right to Vote. The Contested History of Democracy in the United States. Basic Books, 2000, p. 263-266; SITKOFF, Harvard. op. cit., p. 173-183. LAWSON, Steven F. Running for Freedom: Civil Rights and Black Politics in America Since 1941. 3a ed. Wiley Blackwell, 2009, p. 108-114.

137 "Now we would have had no problem working with SCLC had their approach been compatible with SNCC's values. [...] The problem was in the SCLC approach of massive, temporary mobilization and press agentry as opposed to creating powerfully organized communities capable of sustaining political struggle. [...] SNCC had steadily and purposefully been building on the base already in Selma. [...] Here comes SCLC talking about mobilizing another two-week campaign, using our base and the magic of Dr. King's name. They going [sic] bring in the cameras, the media, prominent people, politicians, rat-tat-tat, turn the place upside down, and split. [...] That was the issue, a real strategic and philosophical difference". CARMICHAEL, Stokely; THELWELL, Ekwueme M. Ready for the Revolution: The Life and Struggles of Stokely Carmichael (Kwame Ture). New York: Scribner, 2003, p. 445. Itálico do autor. 
realizaram novas concessões ao Governo Federal norte-americano que voltaram a irritar os militantes mais jovens do SNCC. Temendo perder o apoio do Governo de Lyndon Johnson e do Congresso necessário à aprovação da Lei do Direito do Voto, o pastor batista interrompeu a marcha até Montgomery poucos dias depois de uma tentativa anterior ter sido brutalmente reprimida pela polícia da cidade e gerado manchetes pelo país. Em um acordo de bastidores, King cedeu às pressões do alto escalão Democrata e acatou uma liminar do judiciário federal impedindo a realização da marcha concebida para evitar novos confrontos que pudessem ser constrangedores para o governo. $\mathrm{Na}$ ocasião, o trato firmado entre as partes estipulou que os cerca de mil e quinhentos manifestantes marchariam até a ponte Pettus Bridge - local das agressões anteriores -, parariam em frente à barricada policial e dariam meia volta. Aceitando as condições, o pastor batista, no entanto, não havia informado o SNCC acerca das negociações, provocando grande revolta entre estes ativistas quando, chegando ao cordão policial, liderou o recuo da marcha. ${ }^{138}$

De maneira geral, as marchas de Selma a Montgomery ampliaram ainda mais as divisões políticas à época latentes entre as distintas forças que compunham o movimento negro. Em meio aos seus desacordos com a SCLC, Carmichael e o SNCC planejavam retornar ao que era característico ao grupo: a organização comunitária. Assim, recusando tanto as mobilizações “de curto prazo" empregadas pelas lideranças tradicionais dos Direitos Civis quanto a associação destas com o establishment político do país, os militantes do SNCC engajaram-se no ativismo de base em Lowndes County, condado situado entre Selma e Montgomery. Desta vez, diferentemente das experiências anteriores, Stokely e os demais ativistas direcionavam-se às comunidades rurais do Alabama com o intuito de propor uma política negra ainda mais assertiva, independente e abertamente adversária do Partido Democrata que governava o estado.

\subsection{De liderança regional a nacional: Stokely Carmichael e a virada para a política negra independente}

Em 1965, Lowndes County constituía um bastião do segregacionismo no estado do Alabama. Assim como presenciado por Stokely Carmichael nas áreas rurais do Mississippi, os afro-americanos daquele condado eram submetidos a escolas segregadas e inferiores às dos

${ }^{138}$ SITKOFF, Harvard. The Struggle For Black Equality, 1954-1992. New York: Hill and Wang, 1993, p. 177-179; LAWSON, Steven F. op. cit., p. 114-115. 
brancos, sujeitos a habitações precárias e à exploração econômica do trabalho agrícola e doméstico. Ademais, a despeito de representarem oitenta por cento da população de Lowndes, a população negra local era impedida de exercer quaisquer funções político-administrativas devido a repressão das autoridades racistas. Dessa maneira, à época da chegada do SNCC, dos cerca de cinco mil afro-americanos elegíveis para votar, nenhum deles estava devidamente registrado. ${ }^{139}$

Ao final da marcha de Selma para Montgomery, a ida de Stokely Carmichael para o condado de Lowndes acompanhava a "janela de oportunidades" possibilitada ao ativismo negro pela aprovação da Lei do Direito de Voto. Com a ratificação da medida em agosto de 1965, oficiais federais (federal registrars) foram deslocados para diversos pontos do Sul dos Estados Unidos - em particular para o Black Belt, região composta por áreas rurais e pobres do Sul segregacionista historicamente ligadas à exploração da mão de obra escrava para o plantio de algodão - a fim de garantir que aqueles estados cumprissem a nova legislação e não mais impusessem barreiras discriminatórias para barrar o eleitorado afro-americano do acesso ao voto. $^{140}$

A presença dos oficiais contribuiu para intensificar as demandas históricas da população de Lowndes pelo acesso a direitos políticos e trabalhistas, bem como a recursos e serviços que lhes eram negados pelas autoridades brancas: subsídios agrícolas, educação de qualidade e tratamento digno pela polícia. Neste contexto, aliando-se aos ativistas negros oriundos do condado, Carmichael e o SNCC valeram-se de uma brecha no código legal do estado do Alabama para criar um partido político integralmente negro e independente do Partido Democrata. A organização, nomeada LCFO - Lowndes County Freedom Organization, inseria-se nos planos de Carmichael de retornar à organização política comunitária após o Freedom Summer como um meio de solucionar as divisões internas evidenciadas no retiro do SNCC em Waveland. ${ }^{141}$

\footnotetext{
139 JEFFRIES, Hasan Kwame. Bloody Lowndes. Civil Rights and Black Power in Alabama's Black Belt. New York: New York University Press, 2009, p. 1.

${ }^{140}$ SITKOFF, Harvard. op. cit., p. 184-185; CARMICHAEL, Stokely; THELWELL, Ekwueme M. op. cit., p. $462-463$.

141 JOSEPH, Peniel E. op. cit., 2014, p. 88-89; JEFFRIES, Hasan Kwame. op. cit, p. 146-148; CARMICHAEL, Stokely; THELWELL, Ekwueme M. op. cit., p. 439.
} 


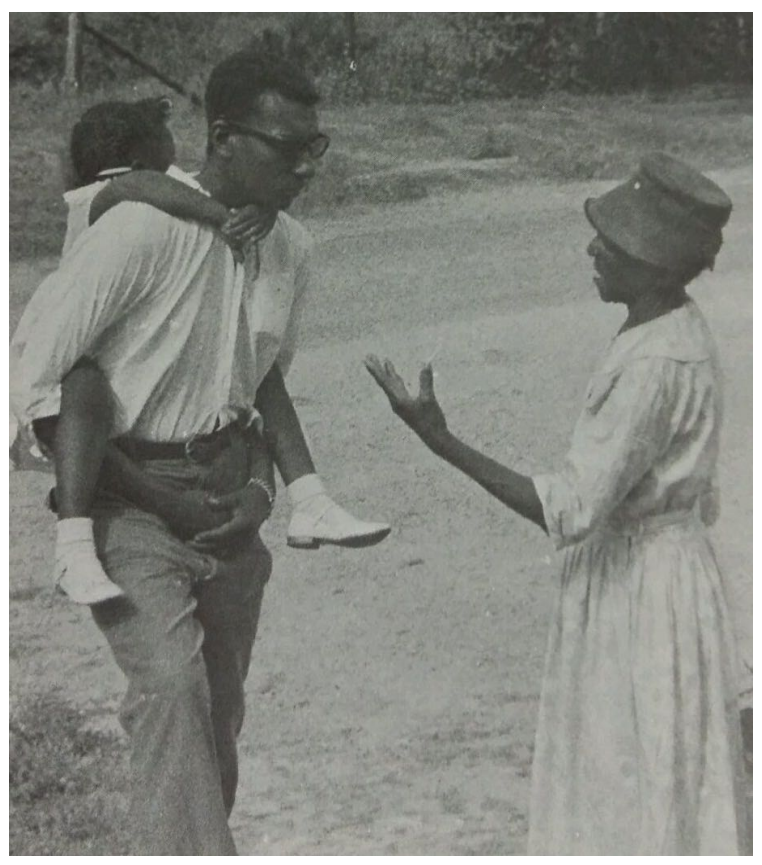

Imagem 6 - Stokely Carmichael durante os trabalhos de registro eleitoral desenvolvidos pelo SNCC junto aos afro-americanos do condado rural de Lowndes County, em 1965. Fonte: CARSON, Clayborne. op. cit., p. 152-153.

Desta vez, contudo, informado pelo insucesso da aliança com o Partido Democrata tentada em Atlantic City, a criação da organização alinhava-se à busca de Carmichael e de uma parte do SNCC por um engajamento político negro, local e independente capaz de conferir voz e representatividade política aos afro-americanos mais pobres e excluídos. Baseando-se nessas premissas, o LCFO tinha como objetivo selecionar expoentes da comunidade negra de Lowndes para concorrerem a cargos públicos nas eleições locais de 1966 - dentre eles, xerife, assessor fiscal (tax assessor) e membros do conselho escolar - a fim de conquistar aos afro-americanos rurais o controle político da administração do condado. ${ }^{142}$ Era, portanto, justamente nesse caráter popular da organização que consistia, segundo Stokely, o seu projeto político transformador:

"Não seria radical se as pessoas do SNCC concentrassem os cargos políticos ou até se M. L. King se tornasse presidente se as decisões ainda forem tomadas de cima para baixo. Se as decisões forem tomadas de baixo para cima, aí sim é radical'" ${ }^{143}$

\footnotetext{
${ }^{142}$ JOSEPH, Peniel E. op. cit., 2014, p. 87; JEFFRIES, Hasan Kwame. op cit., p. 149-151.

143 "It's not radical if SNCC people get political offices, or if M.L. King becomes President, if decisions are still made from the top down. If decisions get made from the bottom up, that's radical". JEFFRIES, Hasan Kwame. op. cit., p. 150.
} 
Assim, ainda que mantivesse as estratégias usuais de registro eleitoral e conscientização política da população afro-americana rural, a fundação do LCFO apontava para a radicalização crescente de Carmichael e do SNCC após o Freedom Summer. Em Lowndes, diferentemente do caso do MFDP, os ativistas estavam dispostos a recorrer à autodefesa armada como estratégia de resistência frente ao terror racial perpetrado por organizações racistas como a Ku Klux Klan. ${ }^{144}$ Como prova da seriedade de suas intenções, os membros do LCFO adotaram a pantera negra para simbolizar sua oposição ferrenha ao Partido Democrata segregacionista do Alabama cujo emblema era um galo branco.

Bem recebida, a iniciativa repercutiu entre o ativismo negro do período, conferindo certa notoriedade para Stokely Carmichael entre os círculos do movimento. Meses depois, inspirados por sua liderança em Lowndes, os estudantes universitários Huey P. Newton e Bobby Seale notabilizariam a imagem da pantera adotada pelo LCFO ao fundarem, em outubro de 1966, o célebre Partido dos Panteras Negras Para a Autodefesa (em inglês, BPP - Black Panther Party for Self-Defense) em Oakland, Califórnia. ${ }^{145}$ Inicialmente, os Panteras de Oakland centraram seus esforços na luta contra a brutalidade policial e na oferta de serviços básicos - programas alimentares, atendimento médico e educação comunitária - aos residentes negros das grandes cidades. Voltados às implicações do racismo em contextos urbanos, Seale e Newton buscavam articular os conceitos de raça e classe na militância do grupo. Durante a década de 1960, os Panteras Negras adotaram uma perspectiva nacionalista negra e revolucionária, combinando as ideias separatistas de Malcolm X a uma leitura eclética do marxismo inspirada pelas reflexões de Lênin, Che Guevara, Frantz Fanon e Mao Tsé-Tung. Em uma formulação própria, acreditavam na capacidade das camadas mais expropriadas dos guetos urbanos - os negros "da quebrada" (brothers on the block, como eles diziam) - que viviam à margem da lei e do mercado de trabalho de se organizarem e insurgirem contra o racismo e o sistema capitalista norte-americano. ${ }^{146}$

No contexto do Alabama, contudo, a escolha da pantera negra pelo LCFO remetia à disposição da comunidade afro-americana rural da região de reagir à violência racial sulista a que

${ }^{144}$ JEFFRIES, Hasan Kwame. op cit., p. 3-4.

${ }^{145}$ OGBAR, Jeffrey O.G. Black Power: Radical Politics and African American Identity. Baltimore: The John Hopkins University Press, 2004, p. 77.

${ }^{146}$ Sobre as perspectivas, a trajetória e as ideias do Partido dos Panteras Negras, cf. HAYES, Floyd W.; KIENE, Francis A. "All Power to the People": The Political Though of Huey P. Newton and The Black Panther Party. In: JONES, Charles E. (Org.). The Black Panther Party Reconsidered. Ed. Kindle. Black Classic Press: 1998 e BLOOM, Joshua; MARTIN Jr., Waldo E. Black against Empire: The history and politics of the Black Panther Party. Oakland: University of California Press, 2016. 
era submetida e buscar representação política nas instâncias administrativas de Lowndes County de forma a assegurar as suas necessidades básicas de sobrevivência. Nas palavras de John Hulett, um dos ativistas locais fundadores da nova organização: “A pantera negra é um animal que, quando pressionada, recua até ficar encurralada. Em seguida, ela sai lutando por vida ou morte. Nós sentimos que fomos encurralados por tempo suficiente e que era hora dos negros saírem e assumirem o controle". ${ }^{147}$

Para Carmichael, o significado simbólico do animal também se fazia claro: para além do poder de reação, a imagem da pantera evocava, "um belo e vigoroso animal representativo da força e dignidade das demandas dos negros atualmente". Segundo o ativista, portanto, esse símbolo traduzia a realidade daqueles que "[...] precisavam suportar - como centenas de pessoas no Alabama suportavam - o desemprego, despejo, fome e, às vezes, até a morte em decorrência de atividades políticas". ${ }^{148}$

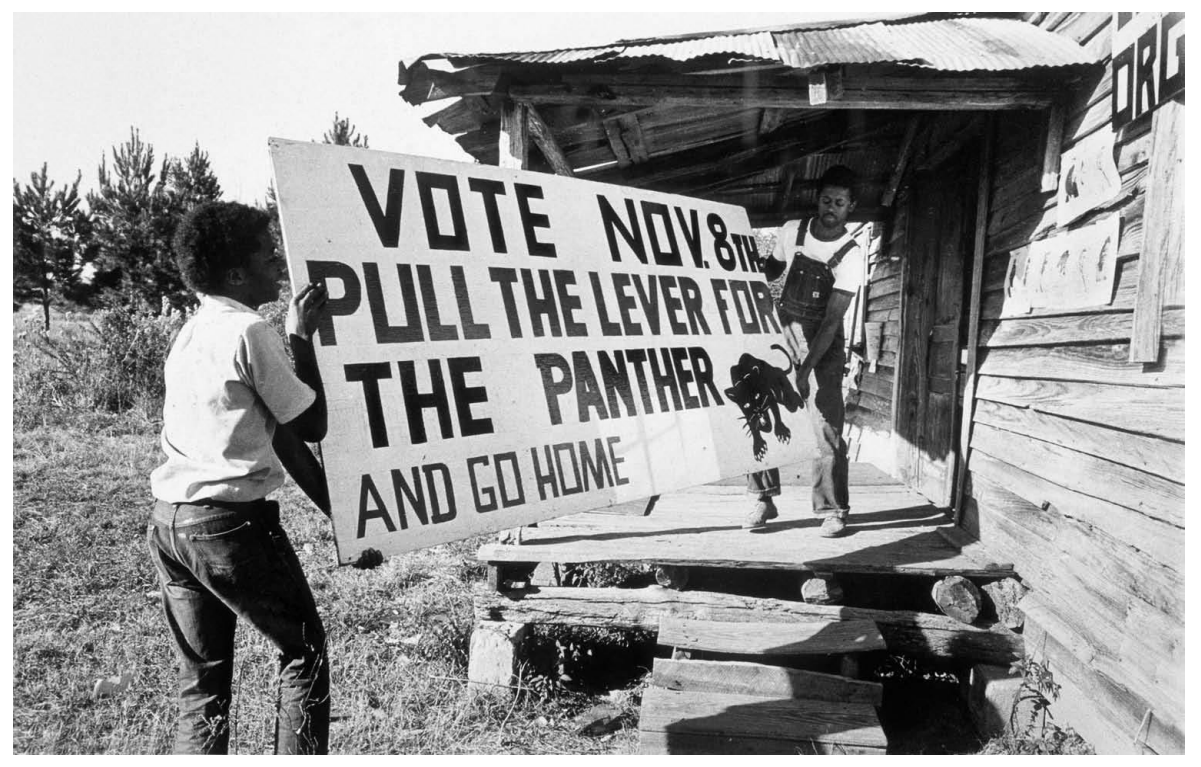

Imagem 7 - Em 1966, Ralph Featherstone, membro do SNCC, e um ativista do condado de Lowndes, Alabama, carregam um anúncio convocando a população para votar nos candidatos do LCFO que concorriam contra os Democratas nas eleições por cargos públicos na região. A pantera negra, emblema do grupo no pleito, representava a postura militante dos ativistas que reivindicavam dignidade e poder político para os afro-americanos do condado. Fonte: fotografia de autoria de Bob Fletcher. Lowndes County, Alabama, 1966. In: KELLEN, Leslie (ed.). This Light of Ours. Activist photographers of the Civil Rights Movement. Jackson: University Press of Mississippi, 2011, p. 122.

\footnotetext{
147 "The black panther is an animal that when it is pressured it moves back until it is cornered, then it comes out fighting for life or death. We felt we had been pushed back long enough and that it was time for Negroes to come out and take over". CARSON, Clayborne. op. cit., p. 166.

${ }^{148}$ OGBAR, Jeffrey O.G. op. cit., p. 75-76; JEFFRIES, Hasan Kwame. op. cit., p. 152.
} 
Produto das experiências e frustrações do SNCC com o Partido Democrata, a atuação de Carmichael junto ao LCFO sinalizava, portanto, uma inflexão nas perspectivas políticas que embasaram o envolvimento do ativista e da militância estudantil negra nas campanhas dos Direitos Civis anteriores. Em grande parte por isso, Stokely, até então um ativista de alcance regional, conquistava projeção nacional à medida que suas críticas públicas e contundentes à marginalização dos afro-americanos na sociedade e na política norte-americanas geravam repercussão midiática. Assim, em Lowndes, para além da cobertura realizada por grandes veículos da imprensa nacional como o jornal The New York Times e a rede televisiva CBS, Carmichael havia chegado às páginas da revista de entretenimento Look Magazine e de uma conhecida antologia de entrevistas com lideranças do movimento negro intitulada Who Speaks for the Negro?, publicada pelo escritor Robert Penn Warren em 1965. ${ }^{149}$ Aos poucos, portanto, as declarações do ativista contribuíram para a sua transformação em uma liderança negra nacionalmente reconhecida, processo este que, como veremos adiante, atingiu seu ápice com a ascensão de Stokely ao posto de liderança no movimento Black Power.

É desse período, também, o texto que inaugurou as primeiras reflexões de Carmichael acerca do movimento negro no país. Publicado em janeiro de 1966 pela revista liberal The New Republic, o artigo Who is Qualified? abre com uma provocação acerca dos padrões nacionais de discriminação racial e econômica que informavam a luta local do LCFO por representatividade e participação política para os afro-americanos de Lowndes. ${ }^{150}$ Segundo coloca o ativista, a despeito do que era usualmente pensado, a mobilidade social não representava uma possibilidade para a maioria da população pobre e marginalizada dos Estados Unidos. Ao contrário das elites e classes médias brancas, esse amplo segmento composto, grosso modo, por afro-americanos e brancos pobres, permanecia preso em uma condição subalterna na medida em que os caminhos existentes para a ascensão social no país - dinheiro, influência e acesso à educação - não lhes eram disponíveis:

"Eu não seria o primeiro a apontar a capacidade Americana para a autoilusão. Uma das principais razões para a crítica à sociedade Americana pelo Students for a Democratic Society [SDS], pelo Student Nonviolent

\footnotetext{
${ }^{149}$ WARREN, Robert Penn. Who Speaks for the Negro? 2. ed. New Haven and London: Yale University Press, 2014; JOSEPH, Peniel E. op. cit., 2014, p. 88; 91; 97-98.

${ }^{150} \mathrm{O}$ artigo Who is Qualified?, foi posteriormente compilado na coletânea Stokely Speaks que apresentaremos no capítulo seguinte. CARMICHAEL, Stokely. Who is Qualified? In: Speaks: From Black Power to Pan-Africanism. 2. ed. Lawrence Hill Books, 2007, p. 9-16. . Stokely
} 
Coordinating Committe [SNCC] e por outros grupos é que a nossa sociedade é excludente enquanto mantém que é inclusiva. Embora a automação [do trabalho] tenha nos levado a repensar o mito de Alger [i.e., o lugar-comum que busca um escape da pobreza por meio de um enriquecimento imprevisto e fantasioso] e a ascensão social, poucas pessoas são realistas quanto às maneiras pelas quais alguém legalmente pode 'se dar bem' aqui - ou mesmo quem pode se dar bem. ${ }^{151}$

Nesse cenário, os afro-americanos, em particular, encontravam-se em uma desvantagem ainda maior. Como aponta o ativista, desprovidos das suas tradicionais fontes de renda devido à mecanização crescente do trabalho fabril e agrícola em todo o país, os negros - os sulistas, principalmente - estavam sujeitos, ademais, a uma educação extremamente precária resultante de décadas de segregação racial na região. Como consequência disto, "ele [o afro-americano] é de fato, não-empregável, do Delta do Mississippi a[o bairro de] Watts [em Los Angeles]”. ${ }^{152}$

Economicamente destituídos e vítimas do racismo, os negros constituíam um “microcosmo dentre os excluídos" para os quais o poder político afigurava-se, mesmo após a Lei do Direito de Voto, como uma impossibilidade, uma prerrogativa dos "habilitados" (qualified); isto é, dos detentores dos meios de ascensão social listados anteriormente. ${ }^{153}$ Fazendo referência às dificuldades enfrentadas pelo SNCC no Mississippi e em Lowndes, Carmichael apontava que a reversão desse quadro não ocorreria de "cima para baixo", ou seja, por obra do governo federal e/ou do Partido Democrata, mas somente através da mobilização política e dos sacrifícios feitos pelos marginalizados:

“O status quo persiste porque não há caminhos para a ascensão social. Quando melhorias foram feitas, elas resultaram da pressão - pressão dos de baixo. Nada foi dado; os governos não distribuem justiça social porque é uma coisa boa a se fazer. As pessoas devem lutar e morrer primeiro: Goodman, Schwerner e Chaney [durante o Freedom Summer, no Mississippi], e, no condado onde estou trabalhando [Lowndes, Alabama], a Sra. Viola Liuzzo e Jonathan Daniels". ${ }^{154}$

151 “I wouldn't be the first to point out the American capacity for self-delusion. One of the main reasons for the criticism of American society by the Students for a Democratic Society, the Student Nonviolent Coordinating Committee and other groups is that our society is exclusive while maintaining that it is inclusive. Although automation has prompted some rethinking about the Alger myth and upward mobility, few people are realistic about the ways in which one legally can 'make it' here - or who can make it". Ibidem, p. 9-10. Itálicos do autor.

${ }^{152}$ CARMICHAEL, Stokely. Who is Qualified? In: op. cit., 2007, p. 10-11.

${ }^{153}$ Ibidem, p. 11; 13.

154 "The status quo persists because there are no ways up from the bottom. When improvements have been made, they resulted from pressure - pressure from below. Nothing has been given away; governments 
A exemplo do LCFO, ressalta o ativista, os militantes do SNCC estavam contribuindo para a organização de outros partidos políticos populares e independentes nos condados do Black Belt do Alabama. Ao rejeitarem o alinhamento automático com o Partido Democrata e o caráter excludente que regia a atividade político-partidária, os afro-americanos pobres e iletrados dessas localidades tinham como alvo a democratização da vida pública norte-americana, suas práticas e instituições que lhes eram inacessíveis. ${ }^{155}$ Assim, atestava Carmichael, "o SNCC aprendeu com a experiência do Mississippi Freedom Democratic Party [MFDP] que o negro sulista não precisa apostar suas fichas no Partido Democrata Nacional para ser reconhecido como uma força [política] com a qual é preciso lidar". ${ }^{156}$

Nesse movimento que se propunha independente, a chave para a construção de uma sociedade mais justa e democrática nos Estados Unidos residia, segundo o ativista, no protagonismo político popular e local dos afro-americanos "de baixo", daqueles que o Governo Federal tratava como meros "objetos" dos seus programas sociais e não como sujeitos capazes de articulação política em benefício próprio. Apontando limitações nas medidas de combate à pobreza e à injustiça racial que compunham a "Grande Sociedade" vislumbrada pelo presidente Lyndon Johson, Carmichael deixava entrever as bases de uma agenda política de fundo radical voltada à inclusão dos negros nos processos decisórios mais amplos da sociedade. ${ }^{157}$

don't hand out justice because it's a nice thing to do. People must struggle and die first: Goodman, Schwerner, and Chaney, and, in the county where I am working, Mrs. Viola Liuzzo and Jonathan Daniels". Ibidem, p. 16.

155 JEFFRIES, Hasan Kwame. op. cit, p. 5.

156 "SNCC learned from the Mississippi Freedom Democratic Party experience that the Southern Negro doesn't have to cast his lot with the national Democratic Party in order to be recognized as a force which must be dealt with". Ibidem, p. 14-16.

${ }^{157}$ Em 1964, a ideia da "Grande Sociedade" foi pensada por Lyndon Johnson como forma de estabelecer uma continuidade com os programas do presidente John F. Kennedy assassinado no ano anterior e conferir legitimidade à sua candidatura na corrida presidencial contra o republicano Barry Goldwater. Buscando aproximar-se do legado político do New Deal de Franklin Delano Roosevelt, Johnson propagandeava a "Grande Sociedade" como uma ampla agenda social reformista pautada pela "Guerra à Pobreza" e pelo combate à discriminação racial com vistas à construção de uma "América ideal". Mirando a formação de um duradouro consenso liberal entre a opinião pública norte-americana, o governo Johnson lançou numerosos projetos de fomento ao emprego, saúde, educação, transporte, dentre outros, coordenados pelo Office of Economic Opportunity, agência federal responsável pela gestão dos recursos. Contudo, a partir de 1965, as pautas da "Grande Sociedade" teriam sua implementação inviabilizada e recursos esvaziados em decorrência dos altíssimos gastos investidos pelo governo na Guerra do Vietnã. Sobre a "Grande Sociedade", cf. ISSERMAN, Maurice; KAZIN, Michael. America Divided: The Civil War of the 1960s. Oxford University Press, 2000, p. 108-112; 187-190. 
"A formulação do Presidente Johnson acerca da Grande Sociedade é absurda. A definição vem dele, assim como os meios de entrar nessa sociedade. As pessoas excluídas devem ter a oportunidade de redefinir o que é a Grande Sociedade, e então ela poderá ter significado. Eu deposito minha própria esperança para os Estados Unidos no fortalecimento da crença entre os não-qualificados de que eles são de fato qualificados: eles podem se articular, serem responsáveis e deter poder [político]". ${ }^{158}$

Assim, organizando-se em prol da luta por autonomia e representatividade política para os afro-americanos pobres do Alabama, Stokely Carmichael e os membros do SNCC retiraram da experiência de Lowndes as bases para o direcionamento que o grupo procurava desde o encontro em Waveland. Se, por um lado, o trabalho no Alabama configurou um dos últimos episódios da carreira de Carmichael como um ativista político local pouco conhecido; por outro, as experiências naquele estado influenciaram profundamente a trajetória do militante enquanto uma liderança nacional. Em questão de poucos meses, como discutiremos no próximo capítulo, o modelo de engajamento negro comunitário, independente e popular praticado pelo LCFO Lowndes County Freedom Organization estaria no cerne do programa de autodeterminação política defendido por Carmichael para o movimento Black Power.

\section{3. "Black Power!": a ascensão de Carmichael no SNCC e a enunciação de uma nova agenda política}

Em maio de 1966, enquanto o LCFO sediava a convenção que nomeou os candidatos da organização para as eleições a serem realizadas no condado de Lowndes em novembro, Stokely Carmichael foi eleito presidente do SNCC. Na ocasião, a derrota de John Lewis, candidato mais moderado que ocupava o cargo desde a Marcha Sobre Washington em 1963, conferiu respaldo aos membros do grupo vinculados à luta dos afro-americanos no estado do Alabama. Com a troca de comando, parte da militância do SNCC deixou claro o desejo de adotar um curso mais radical de ativismo baseado nas experiências recentes da organização em Lowndes County. ${ }^{159}$

Portanto, ao assumir o novo cargo, Carmichael encarregou-se de projetar publicamente

\footnotetext{
158 "President Johnson's concept of the Great Society is preposterous. The definition comes from him, as does the means of entering that society. Excluded people must acquire the oportunity to redefine what the Great Society is, and then it may have meaning. I place my own hope for the United States in the growth of belief among the unqualified that they are in fact qualified: they can articulate and be responsible and hold power". CARMICHAEL, Stokely. Who is Qualified? In:

${ }^{159}$ JOSEPH, Peniel E. op. cit, 2014, p. 101. . op. cit., 2007, p. 16.
} 
uma nova identidade para a organização que correspondesse às demandas crescentes de parte dos ativistas por autonomia política e orgulho racial. Influenciada por um núcleo de nacionalistas negros de Atlanta recém-filiados à organização sob a alcunha de Atlanta Project, tal reorientação foi acompanhada por fortes dissensões internas que dividiram membros da "velha" e da "nova" guarda do SNCC. Em pouco tempo, tais transformações políticas que culminaram na eleição de Carmichael à presidência do SNCC levariam o vínculo da organização com o reformismo político dos Direitos Civis ao ponto de ruptura. ${ }^{160}$

Em junho de 1966, a radicalização atravessada pelos ativistas do SNCC desde Atlantic City tomou corpo em meio à última campanha conjunta das principais organizações dos Direitos Civis. Na ocasião, o estopim foi dado quando o ativista afro-americano James Meredith foi atacado em meio a sua "Marcha Contra o Medo", caminhada de um homem só concebida por ele para estimular a participação dos afro-americanos nas eleições primárias do Mississippi. No segundo dia da empreitada, Meredith - que em 1962 havia se tornado célebre como o primeiro estudante negro a matricular-se na University of Mississippi - foi hospitalizado em decorrência de tiros disparados em uma emboscada na saída da cidade de Memphis, Tennessee.

Visitando o ativista em seu leito no hospital, as principais lideranças do movimento negro comprometeram-se a continuar a caminhada até a cidade de Jackson, no Mississippi. Reunidas em Memphis, três gerações de ativistas dos Direitos Civis negociaram a organização e os objetivos da marcha, procurando um terreno comum em meio às diferenças políticas latentes entre as partes. Os líderes veteranos, Roy Wilkins da NAACP - National Association for the Advancement of Colored People e Whitney Young da NUL - National Urban League, comprometeram-se a providenciar o financiamento de apoiadores liberais do Norte bem como a cobertura midiática desde que a manifestação não "comprometesse" a imagem do governo federal e dos seus contatos políticos nacionais. ${ }^{161}$

Já Stokely Carmichael, apoiado pelo diretor do CORE - Congress of Racial Equality, Floyd McKissick, ofereceu uma abordagem distinta mais ajustada às pretensões militantes do SNCC. Para ele, a marcha representava uma oportunidade de desenvolver um trabalho de base com implicações políticas de longo prazo. Deslocando o foco da discussão para a participação

\footnotetext{
${ }^{160}$ CARSON, Clayborne. op cit., p. 196-200; 203-206. CARMICHAEL, Stokely; THELWELL, Ekwueme M. op. cit., p. 486-487.

161 JOSEPH, Peniel E. Waiting 'Til the Midnight Hour. A Narrative History of Black Power. New York: Holt, 2007, p. 132-136.
} 
das comunidades negras e pobres locais, Carmichael tinha em mente um modelo semelhante ao aplicado pelo SNCC em Lowndes, Alabama: a manifestação deveria, em primeiro lugar, fomentar o registro eleitoral dos afro-americanos no Mississippi para que eles exercessem poder e controle político em seus condados. ${ }^{162}$

No embate entre a "velha guarda" dos Direitos Civis e os ativistas do SNCC e CORE, foi Martin Luther King quem, representando a SCLC - Southern Christian Leadership Conference, quebrou o impasse e garantiu a realização da marcha com a ressalva de que esta fosse pautada pela não-violência e mantivesse um caráter interracial. Para o desgosto de Wilkins e Young, King concordou até com a reivindicação colocada por Carmichael de que a segurança dos manifestantes no Mississippi ficasse a cargo dos Deacons for Defense and Justice, grupo de militantes armados da Lousiana que, em diversas ocasiões, protegeu ativistas dos Direitos Civis ameaçados pelo terrorismo praticado por racistas da Ku Klux Klan. ${ }^{163}$

No decorrer do trajeto, Carmichael e King marcharam juntos por dias e desenvolveram uma proximidade pessoal que se sustentaria a despeito das diferenças políticas marcantes que dividiam suas organizações. Stokely, um ativista com uma vasta experiência de atuação nos rincões sulistas afetados pela segregação racial, reconhecia o respeito conquistado pelo líder mais velho entre os afro-americanos pobres da região. Assim, ao longo dos dias de caminhada, lembra Stokely, à medida que os ativistas do SNCC tiveram a oportunidade de "realmente conhecê-lo", King passou a representar não mais um "símbolo ou ícone" do movimento, mas alguém que “compartilhava muito dos nossos valores". No Mississippi, os dois líderes mantiveram um diálogo constante acerca dos objetivos, valores e pautas concernentes ao movimento negro no

${ }^{162}$ CARMICHAEL, Stokely; THELWELL, Ekwueme M. op. cit., p. 494-500.

${ }^{163}$ Fundado no estado da Lousiana em 1964, o Deacons for Defense and Justice foi um grupo composto, em sua maioria, por ex-veteranos das Forças Armadas dos Estados Unidos atuantes na defesa de comunidades negras e de ativistas - em particular do CORE - que eram alvo da perseguição racista no estado. É importante destacar que, embora tornado célebre na segunda metade da década de 1960 pelo Partido dos Panteras Negras de Oakland, o recurso à defesa armada já se fazia presente entre os afroamericanos nas campanhas de Direitos Civis no Sul dos Estados Unidos. Neste contexto, contudo, o sentido era outro: a autodefesa era entendida por eles como um elemento auxiliar ao ativismo cuja existência se fazia necessária em um território declaradamente hostil às mudanças que propunham. Para esses ativistas, diferentemente dos Panteras Negras, a proteção armada não configurava um aspecto central da luta contra a discriminação racial. Assim, em determinadas situações de risco, mesmo ativistas como Martin Luther King, o maior expoente da não-violência no país, tiveram suas casas e suas famílias sob proteção de guardas armados. Sobre os Deacons, cf. WENDT, Simon. The roots of Black Power? Armed resistance and the radicalization of the Civil Rights Movement. In: JOSEPH, Peniel E. (org.). The Black Power Movement. Rethinking the Civil Rights-Black Power Era. New York: Routledge, 2006. 
país. ${ }^{164}$

No entanto, como mencionado, o SNCC possuía uma agenda política própria para a Marcha de Meredith distinta da proposta pelas lideranças negras mais "moderadas". Para Carmichael, Cleveland Sellers (amigo de Stokely da Howard University e diretor dos programas de ativismo da organização) e Willie Ricks (ativista que atuou no condado de Lowndes, Alabama), o episódio constituía uma oportunidade singular para anunciar o Black Power como o novo curso radical a ser seguido pelo grupo. Na cidade de Greenwood - palco de atividades de Carmichael durante o período em que era estudante na Howard University e ativista do Freedom Summer - foi justamente isto que fizeram.

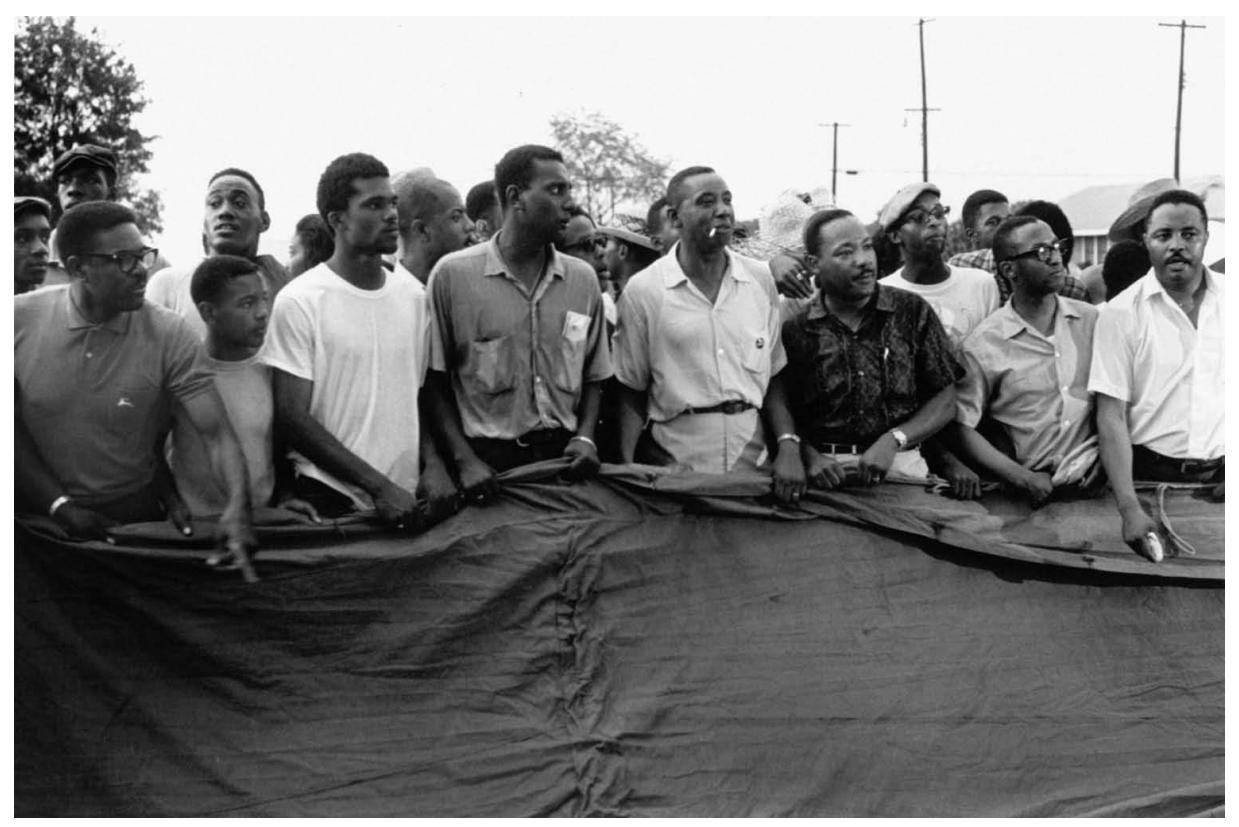

Imagem 8 - Desafiando ordens das autoridades locais, manifestantes erguem uma tenda durante a marcha pelo Mississippi. A despeito de diferenças políticas e ideológicas marcantes entre suas organizações, Stokely Carmichael e Martin Luther King aproximaram-se no decorrer da marcha e estabeleceram uma relação de respeito mútuo que cresceria com o passar dos anos. Esta foi a última vez que as lideranças do Movimento pelos Direitos Civis marcharam juntas. No centro, da esquerda para a direita: Stokely Carmichael, Floyd McKissick do CORE e Martin Luther King da SCLC. Fonte: fotografia de autoria de Matt Herron. Canton, Mississippi, 1966. In: KELLEN, Leslie (ed.). op. cit., p. 177.

No dia 16 de junho, após uma série de intimidações aos manifestantes, Carmichael foi preso arbitrariamente pela polícia da cidade acusado de ter "invadido" o terreno de uma escola onde os integrantes da marcha estabeleceriam seu acampamento noturno. Naquela noite, ao sair da cadeia após horas de espera, o militante direcionou-se ao comício político organizado pelo

${ }^{164}$ CARMICHAEL, Stokely; THELWELL, Ekwueme M. op. cit., p. 502; 510-513. 
SNCC junto à população de Greenwood. Precedido por Floyd McKissick e Willie Ricks, Carmichael subiu no palanque onde fez o que seria, provavelmente, o seu mais célebre discurso: "Esta é a vigésima sétima vez que fui preso. Eu não vou mais para a cadeia. A única maneira de fazermos com que os homens brancos parem de arrebentar conosco é tomar o controle. O que vamos começar a dizer agora é Black Power!". ${ }^{165}$

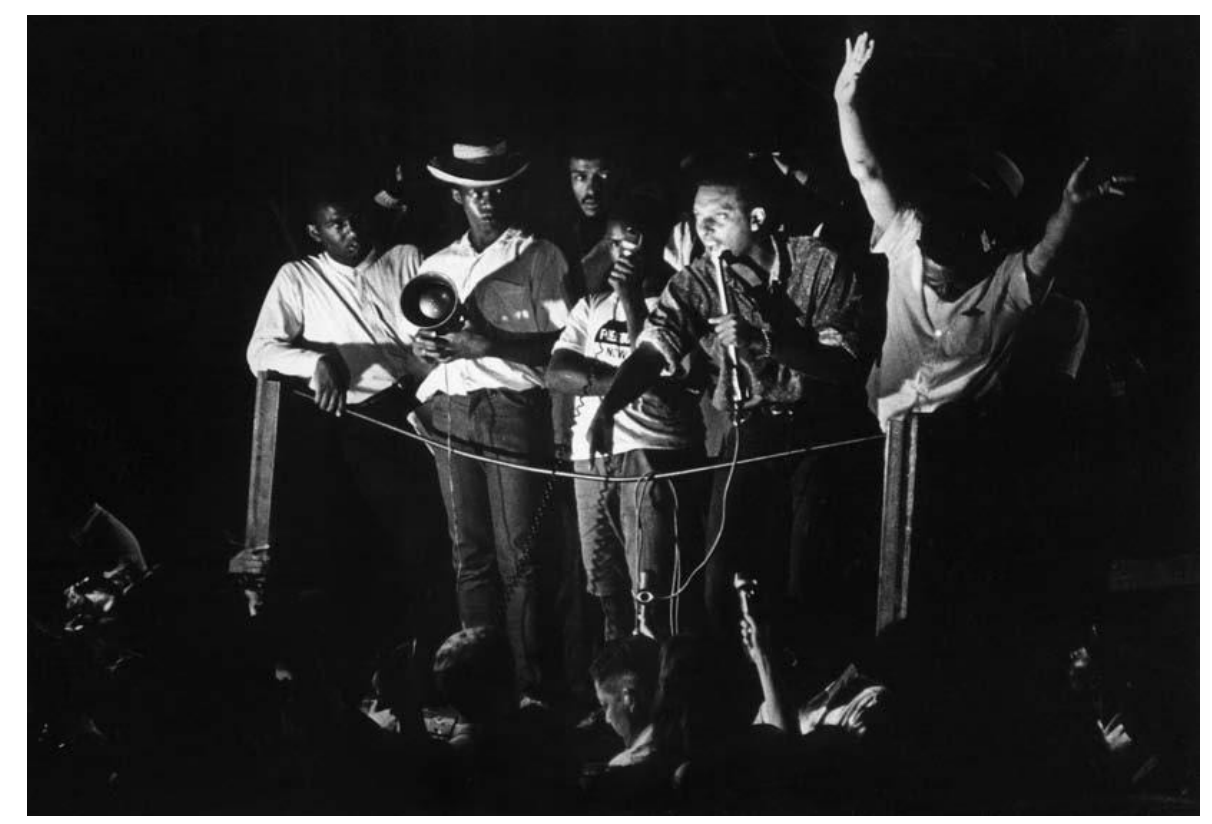

Imagem 9 - Discursando em um comício do SNCC em Greenwood, Mississippi, Carmichael usou o termo "Black Power" pela primeira vez. Segundo ele, a expressão "não representava nada de novo", mas uma continuidade das atividades do SNCC na região do Delta e do Alabama. "A única diferença", destacou ele, "era que, desta vez, a mídia nacional estava presente". Fonte: fotografia de autoria de Bob Fitch. In: KELLEN, Leslie (ed.). op. cit., p. 181.

Respondendo à reação efusiva à sua fala, Carmichael e Ricks incendiavam o público à sua volta lançando a pergunta “o que vocês querem?" respondida, em sequência, por repetidos gritos de “Black Power! Black Power!”. Em um tom particularmente inflamado, Stokely acirrou os ânimos dos presentes declarando que "os brancos do estado do Mississippi não são nada além de um grupo de racistas. [...] Todos os tribunais do Mississippi devem ser queimados para nos livrarmos

\footnotetext{
165 "This is the twenty-seventh time that I've been arrested. I ain't going to jail no more. The only way we gonna stop them white men from whuppin' us is to take over. What we gonna start sayin' now is Black Power!". JOSEPH, Peniel E. op. cit., 2007, p. 142; SOUSA, Rodrigo Farias de. A Nova Esquerda Americana: De Port Huron aos Weathermen (1960-1969). Rio de Janeiro: Editora FGV, 2009, p. 175176.
} 
da sujeira". ${ }^{166}$

Nos dias que sucederam o comício em Greenwood, as tensões entre os membros do SNCC e os representantes da SCLC se intensificaram. Em distintos pontos do trajeto percorrido, Cleveland Sellers e outros membros do SNCC distribuíam adesivos do novo slogan e contrapunham as exortações de "Freedom Now!" lançadas pelos ativistas mais moderados com gritos de "Black Power!". Retornando à marcha após ausentar-se dos eventos em Greenwood, Martin Luther King tentou apaziguar as controvérsias - que, àquela altura, eram amplamente reportadas pelos veículos de imprensa encarregados de cobrir as manifestações - pedindo, sem sucesso, que Carmichael e o SNCC interrompessem o uso do novo slogan. ${ }^{167}$

Encerrada em um grande ato realizado no dia 26 de junho, na cidade de Jackson, Mississippi, a Marcha de Meredith representou um divisor de águas para o Movimento pelos Direitos Civis. Ao expor publicamente as fraturas que há alguns anos dividiam as principais organizações do ativismo negro, o evento marcou a entrada definitiva de uma geração de militantes radicais na cena pública nacional. Dentre eles, Stokely Carmichael, o então presidente do SNCC, emergiu como o principal articulador do Black Power, movimento que revolucionaria a política e identidade negras nos Estados Unidos.

\subsection{A reação nacional ao Black Power: imprensa e movimento negro}

Ainda que, a princípio, o Black Power figurasse como um "slogan", uma "palavra de ordem” lançada pela militância do SNCC no Mississippi, o termo atingiu grande repercussão e gerou muita polêmica nacionalmente. Estava claro para o governo, imprensa, FBI, a Nova Esquerda branca e os veteranos dos Direitos Civis que parte dos negros da geração mais jovem se radicalizava. Após a Marcha de Meredith, a atenção nacional voltou-se ainda mais intensamente às atividades de Stokely Carmichael e do SNCC. Nesse contexto, a grande imprensa que, desde o primeiro semestre de 1966, já caracterizava a criação do LCFO - o partido independente do Alabama cujo símbolo era a pantera negra - e a eleição de Carmichael à presidência do grupo como "ameaças" à luta pelos Direitos Civis, passou a condenar o ativista e o grupo abertamente. ${ }^{168}$ Nos meses subsequentes ao episódio, o novo "slogan" adotado pelo SNCC foi

\footnotetext{
166 “The white folks in the state of Mississippi ain't nothing but a bunch of racists. [...] Every courthouse in Mississippi ought to be burned down to get rid of the dirt". JOSEPH, Peniel E. op. cit., 2007, p. 142.

${ }^{167}$ Ibidem, p. 143-145. JOSEPH, Peniel E. op. cit., 2014, p. 116; 120. OGBAR, Jeffrey O.G. op. cit., p. 62. 168 Acerca da repercussão midiática em torno da eleição de Carmichael à presidência do SNCC, cf.
} 
amplamente comentado, produzindo um intenso debate público acerca dos seus significados que se estendia da imprensa, passando por políticos de grande expressão até representantes nacionais das principais organizações do movimento negro.

De maneira geral, veículos de circulação nacional como o jornal The New York Times e as revistas Newsweek, Time e U.S. News and World Report, teceram duras críticas ao Black Power, atribuindo-lhe um caráter "violento" e "separatista". Acusando-o de ser uma "filosofia racista", uma "política da frustração" advogada por "jovens demagogos", estes impressos colocavam-se ao lado do reformismo político endossado pelo Movimento pelos Direitos Civis em aliança com o Partido Democrata dos Estados Unidos. Nesse sentido, repercutiam amplamente as condenações lançadas aos ativistas do SNCC e CORE por lideranças democratas como o senador Robert F. Kennedy, irmão do ex-presidente John F. Kennedy assassinado em 1963, o presidente Lyndon Johnson e seu vice, Hubert Humphrey. Enquanto Johnson e Kennedy criticaram o "extremismo" dos militantes, alertando que o Black Power poderia ser "prejudicial não somente aos Direitos Civis, mas também ao país", Humphrey foi além, chegando até a acusar os ativistas de racismo: "nós devemos rejeitar clamores racistas sejam eles provenientes de uma garganta branca ou negra". 169

Por sua vez, dentro do ativismo negro, os significados do termo também dividiram opiniões e acirraram os ânimos. Ao passo que a militância negra que então se radicalizava - o SNCC, CORE e, posteriormente, o Partido dos Panteras Negras de Oakland, dentre outros - em grande parte distanciava-se dos seus antigos aliados brancos e/ou liberais e abraçava o Black Power, a liderança tradicional respondeu de maneira bastante crítica. ${ }^{170}$ A esse respeito, em

JOSEPH, Peniel E. op. cit., 2014, p. 103-105 e CARMICHAEL, Stokely; THELWELL, E. M., op. cit., p. 487-488.

${ }^{169}$ CARSON, Clayborne. op. cit., p. 219-221; OGBAR, Jeffrey O.G. op. cit., p. 63-67; JOSEPH, Peniel E. op. cit., 2007, p. 146. Cf., também, os editoriais do New York Times no período: "Black Power". The New York Times, 12 jul. 1966, p. 41 e The politics of frustration. The New York Times, 07 ago. 1966, p. 158

${ }^{170}$ Em 1966, por exemplo, o CORE havia se transformado de um grupo interracial, conhecido pela sua filiação à desobediência civil gandhiana e pela idealização das freedom rides, em uma organização predominantemente negra e aliada do SNCC na proposição do Black Power. Em julho daquele ano, logo após a Marcha de Meredith, os delegados do CORE decidiram pela adoção do novo "slogan" durante a vigésima terceira convenção nacional do grupo, evento que, além de Floyd McKissick (diretor da organização), contou também com a presença de Stokely Carmichael. Em finais da década, sob a liderança de Roy Innis, sucessor de McKissick, o CORE, assim como fizera o SNCC, expulsou os ativistas brancos remanescentes no grupo e aderiu ao nacionalismo negro. Propondo, então, a constituição de uma nação negra separada da sociedade norte-americana branca, a organização voltou-se à defesa de que os afroamericanos deveriam exercer o controle - político, econômico e cultural - das comunidades e instituições que lhes diziam respeito. VAN DEBURG, William L. New Day in Babylon: The Black Power Movement 
outubro de 1966, Roy Wilkins da NAACP, Bayard Rustin (o antigo mentor de Carmichael no NAG - Nonviolent Action Group), A. Philip Randolph (sindicalista veterano e um dos propositores da Marcha Sobre Washington) e Whitney Young da National Urban League assinaram um manifesto intitulado Crisis and Commitment criticando o clamor por Black Power. Afirmando que permaneciam "comprometidos com a obtenção da justiça racial pela via do processo democrático", os signatários apressaram-se a demarcar sua distância em relação à militância que adotava o termo:

"Nós rejeitamos quaisquer estratégias de violência, retaliação ou vigilantismo e condenamos tanto os tumultos quanto a demagogia que os alimentam [...]. Estamos comprometidos com a integração pela qual almejamos acabar com todas as barreiras que a segregação e outras formas de discriminação criaram contra o negros americanos a fim de impedi-los de desfrutar os seus direitos humanos e constitucionais". ${ }^{171}$

Wilkins, em particular, foi quem desferiu os mais duros ataques contra os defensores do Black Power no SNCC e no CORE. Ecoando a declaração de Hubert Humphrey, o ativista veterano acusou o novo movimento de promover "racismo reverso" e de ser "anti-branco". Segundo ele, o Black Power constituía uma "Ku Klux Klan reversa" e representava o "pai do ódio e a mãe da violência". ${ }^{172}$

Em tom mais comedido, lideranças como Martin Luther King e Bayard Rustin atribuíram ao termo um caráter “desagregador" que, segundo eles, enfraquecia e fragmentava o apoio nacional à luta afro-americana por direitos civis, políticos e econômicos. Embora evitasse condenar o Black Power e seus ativistas abertamente, King considerava a expressão uma "terminologia infeliz" ("an unfortunate choice of words") que dava margem às conotações de violência atribuídas aos militantes pela imprensa. Para Rustin, o termo representava uma proposta "utópica e reacionária" que, em sua visão, resultaria no distanciamento dos afro-americanos da "principal arena de disputas políticas no país": o Partido Democrata. Por isso, argumentava ele, ao propor, como havia feito no Alabama, que os afro-americanos "tomassem o controle" político

and American Culture. Chicago: The University of Chicago Press, 1993, p. 132-140.

171 "We repudiate any strategies of violence, reprisal, or vigilantism, and we condemn both rioting and the demagoguery that feeds it [...] We are committed to integration, by which we mean and end to every barrier which segregation and other forms of discrimination have raised against the enjoyment by Negro Americans of their human and constitutional rights". OGBAR, Jeffrey O.G. op. cit., p. 63; JOSEPH, Peniel E. op. cit., 2014, p. 153.

${ }^{172}$ OGBAR, Jeffrey O.G. op. cit., p. 64; CARSON, Clayborne. op. cit., p. 219-220. 
dos democratas nos condados sulistas, Stokely Carmichael e o SNCC estariam isolando o ativismo negro politicamente e prejudicando a conquista de melhorias sociais e econômicas aos afro-americanos. Segundo o ativista veterano, os negros constituíam apenas um décimo da população do país e, portanto, não poderiam prescindir do apoio - inclusive financeiro - de setores políticos liberais, trabalhistas e/ou brancos para o avanço de suas pautas:

“Apesar das exortações do SNCC para se organizarem no Partido dos Panteras Negras, os negros sulistas vão permanecer no Partido Democrata - para eles, este é o partido do progresso, do New Deal, da Nova Fronteira e da Grande Sociedade - e eles estão certos em ficar"'. ${ }^{173}$

De maneira geral, os ataques dirigidos pela liderança tradicional ao Black Power advinham do temor de que a radicalização atravessada por setores do ativismo negro - o CORE e o SNCC, em particular - comprometesse o "apoio" Democrata conquistado a duras penas pelo Movimento dos Direitos Civis após anos de protestos, lobbies políticos no Congresso e disputas legais na Suprema Corte. Ademais, é importante notarmos que tais condenações efusivas vindas de políticos e organizações dos Direitos Civis inseriam-se em um ambiente político e racial profundamente polarizado, marcado por sucessivas rebeliões nas cidades e nos guetos urbanos que concentravam, de maneira precária, a população afro-americana do Norte a Oeste do país.

À época, tal adensamento populacional afro-americano originava-se, como indicamos no primeiro capítulo, das Grandes Migrações internas da primeira metade do século XX que levaram milhões de afro-americanos sulistas às cidades do Norte e Oeste em busca de melhores condições de vida. No período do pós-Guerra, esta dinâmica de urbanização marcadamente racializada aprofundou-se ainda mais à medida que milhões de proprietários brancos de classe média, beneficiados pela prosperidade econômica do país nos anos 1940 e 1950, mudaram-se para enclaves suburbanos exclusivos, isolando-se dos migrantes negros recém-chegados. Gozando de incentivos fiscais, estabilidade no mercado de trabalho e amplo acesso ao crédito imobiliário e educativo, esses compradores realocaram grande parcela dos impostos, serviços e empregos que anteriormente alimentavam os centros urbanos para suas novas áreas de residência. Com o tempo,

173 "Southern Negroes, despite exhortations from SNCC to organize themselves into a Black Panther Party, are going to stay in the Democratic Party - to them it is the party of the progress, the New Deal, the New Frontier, and the Great Society - and they are right to stay". Cf. RUSTIN, Bayard. Black Power and Coalition Politics. Commentary, n. 42, pp. 35-40, set. 1966, p. 35-36. Disponível em: $<$ http://www.crmvet.org/info/6609_rustin_blkpwr.pdf $>$. Acesso em: 31 de agosto de 2017 e KING JR, Martin Luther. Where do We Go from Here: chaos or community? Boston: Beacon Press, 1967, p. 30. 
esse processo - conhecido como white flight, ou "fuga dos brancos" - reconfigurou a demografia urbana nos Estados Unidos para um perfil moldado à imagem da classe média branca. Juntamente a outras práticas excludentes como demolições, remoções populacionais e abertura de vias, isso foi decisivo para a formação de cidades e subúrbios altamente segregados e desiguais. ${ }^{174}$

Como resultado desse processo, entre 1964 e 1970, milhares de afro-americanos revoltaram-se contra as condições de vida opressivas que enfrentavam nos centros e guetos urbanos norte-americanos pauperizados. De maneira geral, diversos fatores contribuíram para o estopim dos levantes em mais de 300 cidades no decorrer do período: desemprego e privação econômica, histórico de violência policial contra a população negra, conivência governamental com a segregação urbana que impunha condições precárias de saúde, educação e habitação aos negros, dentre outros. Algumas dessas rebeliões foram de grande expressão e resultaram em confrontos intensos entre manifestantes e a polícia, na destruição de numerosos prédios, lojas e em uma brutal repressão policial auxiliada, frequentemente, por forças militares e pela Guarda Nacional. Enquanto em Nova York (1964) cerca de 550 pessoas foram presas e 150 ficaram feridas, no bairro de Watts em Los Angeles (1965) os conflitos resultaram na morte de 34 pessoas e no incêndio de uma área de cerca de 120 quilômetros quadrados. Em 1967, os confrontos foram ainda mais expressivos nas cidades de Newark (New Jersey) e, principalmente, Detroit (Michigan), onde dezenas de pessoas morreram e milhares de edifícios foram incendiados. ${ }^{175}$

Nesse contexto explosivo, portanto, o radicalismo e a retórica inflamada demonstrada por Stokely Carmichael e por outros proponentes do Black Power foram prontamente identificados pelos seus opositores brancos e/ou liberais como responsáveis por fomentar a virulência dos

\footnotetext{
${ }^{174} \mathrm{Um}$ instrumento governamental indispensável para reconfigurar a demografia urbana e distribuir renda (em termos racialmente desiguais, é preciso lembrar) foi o G.I. Bill (1944), medida que oferecia crédito imobiliário, educacional (ampliando o acesso ao ensino superior) e empresarial para veteranos que retornavam da Segunda Guerra Mundial. Para além da qualificação da mão-de-obra e o aquecimento do mercado de trabalho, a medida foi decisiva para assegurar à classe média norte-americana branca um poder de compra e uma estabilidade financeira que se estenderiam à geração seguinte dos anos 1960, os chamados baby boomers. Para uma discussão detalhada do processo de urbanização e ascensão da classe média suburbana, cf. FREEMAN, Joshua B. American Empire. The rise of a global power, the democratic revolution at home, 1945-2000. New York: Penguin Books, 2013 e o estudo de caso da cidade de Oakland, Califórnia, em SELF, Robert O. American Babylon. Race and the Struggle for Postwar Oakland. Princeton University Press, 2003.

${ }^{175}$ GERSTLE, Gary. American Crucible: Race and Nation in the Twentieth Century. Princeton and Oxford: Princeton University Press, 2002, p. 301; ABU-LUGHOD, Janet L. Race, space and riots in Chicago, New York, and Los Angeles. Oxford University Press, 2007, p. 23-28; VAN DEBURG, William L. op. cit., p. 11-15.
} 
"distúrbios" civis. Assim, o Black Power foi, logo de início, amplamente caracterizado na grande mídia e entre setores políticos moderados - brancos e, em alguns casos, também negros - como um fenômeno "violento" e "destrutivo" que não ofereceria soluções aos dilemas impostos pelo racismo aos negros nos Estados Unidos. ${ }^{176}$

Alvo, portanto, de uma pluralidade de significados e interpretações frequentemente negativas que, em geral, visavam desqualificar a militância negra que se radicalizava, o Black Power carecia, ainda, de definições e de uma orientação programática mais claras. Atento a isso, a partir do segundo semestre de 1966 e durante todo o ano de 1967, Stokely Carmichael dedicouse a delimitar os contornos nacionais e transnacionais do novo movimento através da publicação de escritos e obras sobre o tema e da realização de numerosos discursos no país e no exterior. Naquele momento, como veremos no próximo capítulo, a radicalização atravessada pelo ativista e pela militância negra dos Direitos Civis traduziu-se em um projeto político profundamente crítico do racismo e das relações raciais norte-americanas, bem como dos valores cívicos e instituições sociais em vigor nos Estados Unidos. Projetando uma identidade negra assertiva, a geração de Carmichael no movimento Black Power introduziu uma profunda fratura na identidade e narrativa nacionais norte-americanas.

${ }^{176}$ VAN DEBURG, William L. op. cit., p. 13-14. 


\section{CAPÍTULO 3 - Por uma identidade e política negras nos Estados Unidos: o projeto político de Stokely Carmichael no livro Black Power: The Politics of Liberation (1966-1967)}

Como vimos nos capítulos anteriores, em meados da década de 1960, o movimento Black Power despontava nos Estados Unidos a partir da frustração dos ativistas - particularmente entre estudantes e jovens negros ligados ao SNCC - com o establishment político liberal representado pelo Partido Democrata. Após anos de lutas do movimento negro no âmbito dos Direitos Civis, o desemprego e a privação econômica, a violência policial, a conivência nacional com a segregação urbana que impunha condições precárias de saúde, educação e habitação nos guetos negros das grandes cidades mantinham-se amplamente intocadas país afora. A lentidão das reformas sociais e a insuficiência dos programas assistencialistas da "Grande Sociedade" do governo de Lyndon Johnson tornavam-se, então, evidentes. Ano após ano, multiplicavam-se os levantes e as rebeliões entre grupos urbanos marginalizados (em particular os afro-americanos) cuja indignação refletia e informava a ampla radicalização política entre parcela da população negra do período.

Nesse cenário crítico, o Black Power proposto por Stokely Carmichael era, também, fruto da percepção cada vez mais difundida entre os afro-americanos de que a opressão racial constituía um fenômeno de caráter estrutural, fundante, no país. Ele articulava a revolta da militância negra contra os "valores e instituições" norte-americanos que, mesmo após o fim formal (i.e., legal) da segregação racial, continuavam a sustentar a exclusão - econômica, política, cultural - dos afro-americanos.

Dessa forma, nesse capítulo discutiremos o projeto político de Stokely Carmichael para o movimento Black Power nos Estados Unidos focando na sua principal obra, o livro Black Power: The Politics of Liberation e nos primeiros artigos e discursos da coletânea Stokely Speaks: From Black Power to Pan-Africanism. Para tanto, analisaremos como a proposição desta agenda política era motivada pela leitura do racismo como um fenômeno "total", estruturante das instituições, dos valores e da identidade norte-americanas; o qual deveria ser combatido por meio da autodefinição identitária e autodeterminação política entre os afro-americanos.

Buscaremos, ainda, apresentar como as obras articulam um programa radical - inspirado, sobretudo, pelo nacionalismo negro de Malcolm X, mas também por outras influências dentro do Movimento Black Power - e crítico ao pretendido pelas lideranças dos Direitos Civis ao defender que os negros se organizassem em blocos políticos autônomos capazes de tomar o controle das 
suas comunidades. Por fim, trataremos da repercussão e das tensões que atravessavam o projeto político de Carmichael: à medida que retinha, ainda, alguma esperança de encontrar um "lugar" para os negros nos Estados Unidos, as proposições contidas na obra apontavam, contudo, para uma ruptura iminente do ativista com a nação e identidade nacional norte-americanas.

\subsection{O espectro político e cultural do Movimento Black Power}

Entre a segunda metade da década de 1960 e meados dos anos 1970, o movimento Black Power constituía um fenômeno extremamente abrangente cujas manifestações repercutiam profundamente nas mais variadas instâncias da vida social, cultural e política norte-americana. Devido a essa complexidade, é impossível, portanto, falar de um único Black Power nos Estados Unidos. Ao contrário, o movimento deve ser compreendido como uma miríade de proposições, sujeitos e agendas políticas e culturais que se cruzavam nos mais distintos espaços ocupados pela juventude negra urbana na sociedade norte-americana: dentre eles, os guetos, os campi universitários, as fábricas, a indústria cultural e de entretenimento, as forças armadas, os esportes (profissionais e amadores) e, à medida que crescia a repressão policial às comunidades negras e suas lideranças, as prisões.

De um lado, dada a sua visibilidade midiática, a música e os esportes, portas primeiras da inclusão, constituíam espaços privilegiados de manifestação política e resistência cultural compartilhados pela geração do Black Power. Na década de 1960, numerosos grupos musicais e artistas como James Brown e Nina Simone - para citar apenas dois - despontavam nacionalmente com hits que refletiam a conscientização identitária crescente entre o público negro jovem. Considerado o "Padrinho" (Godfather) da música soul, Brown eletrizava plateias com exortações de "Diga alto! Sou negro e tenho orgulho!" ('Say it loud! I'm black and I'm proud!") enquanto Simone cativava o orgulho dos ouvintes ao cantar a beleza dos traços físicos negros na canção Ain't Got no, I Got Life: "Eu tenho meu cabelo, tenho minha cabeça / Tenho meu cérebro, tenho meus ouvidos / Tenho meus olhos, tenho meu nariz / Tenho minha boca / Tenho a mim mesma". ${ }^{177}$

\footnotetext{
${ }^{177}$ Trecho original da canção de Simone: "I got my hair, got my head / Got my brains, got my ears / Got my eyes, got my nose / Got my mouth / I got my / I got myself". Cf. Ain't Got no, I Got Life. In: SIMONE, Nina. 'Nuf Said!'. New York: RCA Records, 1968. Faixa 8 (2 min 08); VAN DEBURG, William L. New Day in Babylon: The Black Power Movement and American Culture. Chicago: The University of Chicago Press, 1993, p. 214.
} 
Nos esportes, cada vez mais atletas afro-americanos conectavam a luta contra o racismo e militarismo norte-americanos às desigualdades de poder dentro de uma indústria do entretenimento milionária sustentada por sua performance e, no entanto, controlada por um empresariado branco. ${ }^{178}$ Em episódios amplamente divulgados pela imprensa, esportistas negros influentes associavam-se à luta do movimento Black Power. Exemplo disso, na sequência da "polêmica" gerada pela recusa do campeão dos pesos-pesados Muhammad Ali - nascido Cassius Clay e posteriormente convertido à Nação do Islã - em servir o país na Guerra do Vietnã no ano de 1967, os corredores John Carlos e Tommie Smith protagonizaram um gesto nas Olimpíadas do México de 1968 que se tornou icônico. Subindo ao pódio descalços e vestindo luvas de couro pretas, ergueram o punho direito durante o hino nacional em um emblemático ato de protesto que marcou o ápice do movimento de boicote aos jogos organizado por atletas-ativistas negros desde o ano anterior.

Em finais da década, muitos radicais afro-americanos também ingressaram no movimento Black Power a partir de experiências junto à luta dos trabalhadores negros em fábricas e à resistência contra o sistema prisional. Mobilizando-se contra práticas discriminatórias de empregadores e sindicatos nas plantas da montadora Chrysler em Detroit, operários negros da indústria automotiva formaram, em 1968, o DRUM - Dodge Revolutionary Union Movement, organização nacionalista negra e marxista que reivindicava a revolução socialista no cerne do capitalismo industrial norte-americano. Cerca de um ano depois, o movimento de trabalhadores negros radicais fomentado pelo DRUM se espalhou para diversos centros urbanos do país. ${ }^{179}$

\footnotetext{
${ }^{178}$ A este respeito, a falta de representatividade negra em cargos administrativos nas ligas profissionais é bastante elucidativa. Nos anos 1960, à exceção de Bill Russell, atleta e ativista dos Direitos Civis multicampeão pelo time de basquete do Boston Celtics, nenhuma equipe no cenário esportivo era gerida por um profissional negro. VAN DEBURG, William L. op. cit., p. 83-92.

${ }^{179}$ O DRUM (Movimento Sindical Revolucionário Dodge, em português) concebia os trabalhadores afroamericanos como a "vanguarda da classe operária", o agente revolucionário por excelência. Organizandose não somente contra as montadoras - primeiro a Chrysler e, depois, a Ford e a General Motors -, o grupo combatia, também, o Sindicato dos Trabalhadores das Indústrias de Automóveis (UAW - United Automobile Workers) e suas práticas excludentes: a cumplicidade com o empresariado, a carência de representatividade sindical imposta aos trabalhadores negros e a discriminação racial nas contratações e no ambiente de trabalho. Opondo-se a alianças com o operariado branco, o DRUM logo inspirou outros "movimentos sindicais revolucionários" em diversos centros industriais que se reuniram, a partir de 1969, em uma só central dedicada a "quebrar o sistema econômico norte-americano": a Liga de Trabalhadores Negros Revolucionários. No entanto, pouco tempo depois, atravessada por dissensões internas, repressão política e enfraquecida pela crise da indústria automobilística nacional, a Liga se dissolveu em 1971. Ibidem, p. 92-97; SHAWKI, Ahmed. Libertação negra e socialismo. Editora Sundermann, 2017, p. 254255.
} 
À maneira do ocorrido com Malcolm X mais de uma década antes, ativistas do Black Power também se radicalizavam a partir da vivência dentro do sistema carcerário norteamericano. Enquanto cumpriam suas sentenças, esses presidiários - percebidos como "presos políticos" de um sistema penal que visa(va) desproporcionalmente a população negra e pobre ${ }^{180}$ iniciaram sua formação política através da leitura de revolucionários marxistas e pensadores negros. Ao passo que, contando com o apoio da militância radical, milhares de presos de todo o país se rebelavam contra as instituições carcerárias e seus agentes, outros conquistaram destaque no movimento negro - como o pantera negra Eldridge Cleaver e o revolucionário George Jackson, por exemplo - através de críticas contundente às prisões norte-americanas publicadas em livros de memórias e best-sellers nacionais. ${ }^{181}$

Os campi universitários, por sua vez, constituíam um dos principais e mais constantes polos de agitação, sociabilidade e conscientização política-identitária do movimento Black Power. Por volta de meados da década de 1960 em diante, um número cada vez maior de afroamericanos ingressava em instituições de ensino superior onde, em muitos casos, o público discente e docente ainda era quase exclusivamente branco. Anteriormente mais engajados com os protestos dos Direitos Civis externos aos muros das universidades, boa parte destes estudantes voltava-se, então, mais diretamente ao espaço estudantil mais próximo: realizavam piquetes e

${ }^{180}$ Cabe destacarmos que, atualmente, os Estados Unidos possuem a maior população carcerária do mundo resultante de décadas de uma política antidrogas baseada no policiamento ostensivo e no punitivismo desproporcional imposto às comunidades negra e hispânica. Não por acaso, portanto, desde o Movimento Black Power, a resistência ao encarceramento em massa de grupos marginalizados consolidou-se como uma bandeira central da luta do movimento negro norte-americano contemporâneo contra o racismo sistêmico no país. A esse respeito, conferir a importante obra da jurista e ativista Michelle Alexander em ALEXANDER, Michelle. A Nova Segregação. Racismo e encarceramento em massa. São Paulo: Boitempo, 2017.

${ }^{181} \mathrm{Na}$ prisão, Eldridge Cleaver tornou-se um admirador de Malcolm X e ávido leitor de pensadores e revolucionários como Rousseau, Karl Marx, Lênin, além de intelectuais negros dentre os quais figuravam W.E.B. Du Bois e Richard Wright. Pouco após o cumprimento de sua pena e a entrada no Partido dos Panteras Negras, Cleaver conquistou notoriedade nacional com a publicação, em 1968, do livro Soul on Ice, uma coleção dos seus escritos do cárcere. Por sua vez, George Jackson, uma das vozes mais proeminentes da luta antiprisonal (e, por um tempo, companheiro da militante comunista e feminista Angela Davis) corria o risco de condenação à pena capital pela morte de um carcereiro durante um confronto dentro da penitenciária Soledad (Califórnia), em 1970. Jackson havia conquistado um amplo público intelectual e artístico de esquerda com o lançamento do best-seller de sua autoria Soledad Brother: The prison letters of George Jackson. No ano seguinte, ele foi morto por agentes penitenciários que descreveram o ocorrido como uma "tentativa de fuga". A notícia de sua morte prematura inspirou um levante na penitenciária de Attica State, Nova York, que se notabilizou pelo massacre de 29 presos e 10 reféns resultante da violência com o qual foi reprimido pelo governador do estado. VAN DEBURG, William L. op. cit., p. 106-111; ELBAUM, Max. Revolution in the air. Sixties radicals turn to Lenin, Mao and Che. 2a ed. London \& New York: Verso, 2018, p. 31-32. 
greves, ocupavam faculdades e prédios administrativos, boicotavam professores, aulas e, em alguns casos, recorriam até ao uso da força contra autoridades.

Embora, de maneira geral, também partilhassem de pautas comuns à Nova Esquerda estudantil como um todo - a oposição à pobreza urbana e à Guerra ao Vietnã, a crítica à corrida armamentista e aos testes nucleares, a denúncia dos laços entre universidades e a indústria da guerra, dentre outros - universitários negros cada vez mais se organizavam em torno de agendas próprias. Entre suas principais preocupações figurava a criação de departamentos e programas de estudos, os Black Studies, cujos currículos e atividades refletissem a conscientização identitária e os anseios políticos da geração do Black Power. Capitaneada por organizações e grêmios estudantis negros em todo o país, esta iniciativa estipulava maior autonomia negra sobre o processo de aprendizagem e a vivência universitária: as aulas, ensinadas por professores afroamericanos e, também, por militantes não-acadêmicos, enfatizavam temas políticos prementes aos afro-americanos, sua cultura e história. Em alguns casos, este movimento levou alguns à busca pela criação de "Universidades Negras" (Black Universities), instituições de ensino superior populares, inteiramente separadas das demais e inspiradas pela noção de que a "faculdade é a comunidade negra". 182

Em suma, o Black Power constituiu um fenômeno complexo, de cunho fortemente mobilizador, dotado de ramificações culturais, políticas, artísticas, identitárias, acadêmicas duradouras. No entanto, a despeito da multiplicidade de suas pautas e recortes, é importante ressaltar que o movimento era atravessado por alguns temas centrais compartilhados, em geral, pelos seus adeptos: o orgulho racial, a valorização das heranças culturais e históricas (as "raízes") negras, a busca por autodefinição identitária e a defesa da autodeterminação política para os afroamericanos. Nesse sentido, segundo coloca o historiador William V. Deburg, ele pode ser compreendido a partir de duas vertentes ideológicas principais que ora aproximavam e ora opunham seus proponentes, sendo ambas fundamentalmente voltadas à questão do exercício do poder político e da (não) participação negra na sociedade e cultura mais amplas: tratam-se do pluralismo e do nacionalismo negro. ${ }^{183}$

\footnotetext{
182 Atualmente, em muitas universidades norte-americanas, há departamentos inteiros de AfricanAmerican Studies e African Studies cuja formação remonta aos programas de Black Studies formados na década de 1960. Sobre o assunto, cf. JOSEPH, Peniel E. Black Studies, student activism, and the Black Power Movement. In: (org.). The Black Power Movement. Rethinking The Civil Rights-Black Power Era. New York: Routledge, 2006. p. 255-277; VAN DEBURG, William L. op. cit., p. 64-82.

${ }^{183}$ Ibidem, p. 25; 112.
} 
Em oposição ao melting pot, isto é, à assimilação - frequentemente entendida pelos militantes como "dissolução", "apagamento" das características particulares de grupo - dos negros no mainstream, os pluralistas enxergavam a sociedade a partir de uma metáfora que posteriormente viria ser conhecida como salad bowl, isto é, um todo social composto por partes autônomas, grupos étnico-raciais e de interesse independentes, competindo por recursos e influência entre si. Para eles, a recusa à assimilação, no entanto, previa, de maneira geral, uma coexistência com os demais grupos sociais - italianos, poloneses, irlandeses, judeus, latinoamericanos, asiáticos, dentre outros - pautada pelo respeito e preservação da "integridade cultural" das partes em benefício de uma sociedade verdadeiramente "plural". ${ }^{184}$

Em termos políticos, os pluralistas se organizavam em torno de demandas por "controle comunitário" negro e alguns lançavam-se aos canais oficiais da política partidária, além de reivindicarem cargos em agências e órgãos governamentais, programas sociais e campanhas eleitorais. Buscando promover sua versão de Black Power dentro da vida econômica, política, educacional e institucional das comunidades negras, tinham como objetivo consolidar "blocos de poder" capazes de atuar e pressionar politicamente pelos interesses e necessidades dos negros urbanos nos níveis local, estadual e federal do governo e da administração pública. Nos casos em que assumia a forma de reivindicações históricas por "autossuficiência" e maior autonomia econômica dos afro-americanos - seja pela criação de empregos, maior distribuição de renda ou pela via do "empreendedorismo negro"- o pluralismo chegou até a atrair expoentes tradicionais do movimento negro como a National Urban League (NUL) e a National Association for the Advancement of Colored People (NAACP). Já para aqueles pluralistas pouco afeitos a essas pautas identificadas à burguesia e classe média negras, a força do pluralismo residia em sua capacidade de eventualmente transformar a realidade social afro-americana a partir de um movimento de base, uma mobilização "de baixo para cima". ${ }^{185}$

Embora em menor número que os pluralistas, os nacionalistas negros constituíam o núcleo mais radical do espectro político do Black Power, compondo a "vanguarda" militante do movimento. Divididos em agendas separatistas, culturalistas e revolucionárias muitas vezes rivais, compartilhavam, em maior ou menor grau, um forte ceticismo quanto à possibilidade de uma coexistência pacífica, harmoniosa e igualitária entre os distintos grupos que compunham a

\footnotetext{
${ }^{184}$ VAN DEBURG, William L. op. cit., p. 25

185 Ibidem, p. 116-121; OMI, Michael; WINANT, Howard. Racial formation in the United States. 3a ed. New York and London: Routledge, 2015, p. 175-176.
} 
sociedade norte-americana - principalmente entre brancos e negros. Em sua visão, era muito improvável e até impossível que os negros conseguissem, em um futuro próximo, conquistar poder de decisão em meio às instituições norte-americanas existentes, em geral brancas. Rebelando-se contra os contornos excludentes que historicamente caracterizavam a comunidade e identidade nacional WASP (White, Anglo-Saxon, and Protestant) no país, esses radicais concebiam o nacionalismo negro como fundamento de uma identidade coletiva "insurgente", baseada em um senso comunitário de pertencimento e filiação étnico-racial (peoplehood) ao "povo negro". 186

Dessa maneira, tendo Malcolm X como "paradigma", referência política central, os nacionalistas defendiam a organização dos afro-americanos em instituições e até em territórios autônomos dos brancos. ${ }^{187}$ Eles estipulavam distintos graus de separação entre a comunidade negra e a sociedade mais ampla: enquanto alguns concebiam uma nação negra "metafórica", entendida em termos primordialmente culturais, voltando-se aos valores e às manifestações estéticas "afrocêntricas" e afro-americanas (Organização US, Ron Karenga e Amiri Baraka, por exemplo); ${ }^{188}$ outros propunham uma separação física e total através da criação de um Estado

${ }^{186}$ Peoplehood é um conceito mobilizado por muitos nacionalistas negros - inclusive Stokely Carmichael - que não possui um equivalente exato em português. Em termos gerais, peoplehood expressa as maneiras pelas quais identidades raciais e nacionais combinam-se na construção de "comunidades imaginadas" divergentes nos Estados Unidos - WASP, negra, hispânica, asiática, etc. Por isso, optamos aqui por uma aproximação ao utilizarmos "povo negro". A este respeito, cf. OMI, Michael; WINANT, Howard. op. cit., p. 75-79; 81-83. Sobre "comunidades imaginadas", ver: ANDERSON, Benedict. Comunidades imaginadas: reflexões sobre a origem e a difusão do nacionalismo. São Paulo: Companhia das Letras, 2008.

${ }^{187}$ Segundo William Van Deburg, graças à sua visibilidade e ao seu ceticismo quanto à possibilidade dos afro-americanos conquistarem plena igualdade social dentro dos Estados Unidos, Malcolm representava mais do que um ícone do nacionalismo e separatismo negros. De fato, após a sua morte, ele se tornaria "[...] o arquétipo, o ponto de referência e o conselheiro espiritual in absentia para uma geração de ativistas afro-americanos. Embora diversa em seus termos e modos de expressão, foi o impulso coletivo desses ativistas em direção ao orgulho racial, força e auto-definição que passou a ser chamado de Movimento Black Power". Mobilizado por distintos lados do espectro negro radical e, principalmente, por expoentes como Stokely Carmichael e o Partido dos Panteras Negras, Malcolm X tornou-se, portanto, um "paradigma", um modelo cultural e político para as múltiplas aspirações da geração do Black Power. Cf. VAN DEBURG, William L. op. cit., p. 2.

${ }^{188}$ Ron Everett (1941 - ), posteriormente conhecido como Ron (ou, ainda, "Maulana" - mestre, professor em suáli) Karenga foi o fundador do "US", organização nacionalista cultural que disputava o cenário político negro radical na região da Baía de São Francisco com o Partido dos Panteras Negras. Situado na cidade de Los Angeles, o grupo defendia a consciência e produção culturais negras como veículos privilegiados de transformação radical da sociedade. Vestindo-se com dashikis (robes africanos tradicionais) e ensinando suaíli (língua majoritária dos povos de origem bantu), os membros buscavam difundir e celebrar uma "cultura africana ancestral" inclusive através da criação do Kwanzaa, feriado de 
negro autônomo com suas próprias leis, território e economia, como a Nação do Islã e, eventualmente, o já citado CORE.

Muitos nacionalistas, inspirados pelas lutas anticoloniais e de independência no Terceiro Mundo, apropriavam-se da tradição marxista para defender a revolução socialista e antirracista nas fábricas, guetos e universidades (Partido dos Panteras Negras e o já mencionado DRUM, por exemplo). Havia, ainda, aqueles que, como fizera Marcus Garvey no começo do século XX, pensaram o nacionalismo negro em diálogo com o pan-africanismo ao sonharem com a fundação de novas nações negras independentes no continente Africano. Em suma, a despeito de suas numerosas divisões e matizes, o campo nacionalista do Movimento Black Power defendia, como um todo, a autonomia sociocultural dos afro-americanos, opunha-se veementemente à “assimilação" negra à sociedade, aos valores e instituições da "América Branca" e evitava, na maioria dos casos, alianças comprometedoras com o establishment político seja do Partido Democrata ou Republicano. ${ }^{189}$

Assim, de maneira geral, as vertentes pluralista e nacionalista mostraram-se predominantes entre os proponentes e adeptos do Movimento Black Power. Por meio da rejeição da integração racial como um ideal suficiente à luta contra o racismo, a militância estabelecia sua distância em relação ao ativismo moderado dos Direitos Civis. Não raro, portanto, as fronteiras que separavam pluralistas dos nacionalistas negros em muitas ocasiões mostravam-se tênues e porosas; frequentemente, estas orientações combinavam-se dentro de uma mesma organização ou até nas proposições de um mesmo ativista - como é o caso de Stokely Carmichael.

Nesse sentido, transitando entre o complexo espectro político e cultural negro da época, Carmichael mobilizou, nas obras de sua autoria, referenciais político-identitários amplamente compartilhados e disputados pela militância afro-americana da sua geração. No processo de constituição e difusão da sua agenda para o movimento, o ativista deu vazão às diversas possibilidades, subjetividades e dilemas políticos que informavam as lutas por "poder negro" dentro - e fora - dos Estados Unidos.

inspiração "africana" alternativo ao Natal cristão. Seguidor de Karenga, o poeta e dramaturgo negro Amiri Baraka (nascido LeRoy Jones, 1934-2014) destacou-se como um dos principais proponentes do Black Arts Movement, uma importante ramificação cultural e artística do Black Power. BLOOM, Joshua; MARTIN Jr., Waldo E. Black against Empire: The history and politics of the Black Panther Party. Oakland: University of California Press, 2016, p. 141; VAN DEBURG, William L. op. cit., p. 171-174.

189 Ibidem, p. 25; 112-113; GERSTLE, Gary. American Crucible: Race and Nation in the Twentieth Century. Princeton and Oxford: Princeton University Press, 2002, p. 295-296. 


\subsection{As obras de Stokely Carmichael}

Como vimos, pouco após a Marcha de Meredith no Mississippi em junho de 1966, Stokely Carmichael, notabilizou-se nacionalmente enquanto porta-voz, a "face pública" e principal propositor do movimento Black Power. À maneira do intelectual engajado, o ativista incumbiu-se do papel de "representar" o ponto de vista da militância negra radical junto ao profundo e polarizador debate público acerca do futuro das relações raciais e do ativismo negro nos Estados Unidos. ${ }^{190}$ Procurando "dar forma" à agenda política do Black Power, Carmichael valeu-se amplamente do palanque, da mídia televisiva e impressa e da escrita para esclarecer seu posicionamento político.

Em pouco mais de um ano, o ativista escreveu dois importantes ensaios - What We Want e Toward Black Liberation - e discursou intensamente perante plateias universitárias brancas e negras dos mais diversos campi do país. Tal atuação configurou as primeiras respostas do líder do SNCC àqueles que se opunham ao Black Power e abriu caminho para a escrita de duas importantes obras de sua autoria: o livro Black Power: The Politics of Liberation, publicado pelo ativista e pelo cientista político Charles V. Hamilton em outubro de 1967, e, posteriormente, a coletânea de artigos e discursos Stokely Speaks: From Black Power to Pan-Africanism, datada de 1971. ${ }^{191}$

Editadas por Toni Morrison, premiada romancista negra que foi professora de Stokely Carmichael na Howard University, ambas as obras foram lançadas sob o selo da Random House, à época uma grande editora nos Estados Unidos que atualmente - após uma fusão em 2013 com o grupo Penguin - compõe um dos maiores conglomerados editoriais de língua inglesa do

${ }^{190}$ SAID, Edward W. Representações do Intelectual: as Conferências de Reith de 1993. Companhia das Letras, 2005, p. 25-27.

${ }^{191}$ Os artigos What We Want e Toward Black Liberation foram publicados, originalmente, nas edições de setembro de 1966 das revistas The New York Review of Books e The Massachusetts Review. Como mencionado, estes textos serviram de base para a argumentação desenvolvida no livro Black Power - no qual os autores incorporaram diversos trechos dos artigos mencionados - e foram posteriormente compilados em Stokely Speaks. Nesta obra, What We Want foi renomeado pela organizadora do volume, Ethel Minor, que o intitulou "Power and Racism". É deste período, também, discursos de Carmichael na University of California em Berkeley (Outubro de 1966) e na Morgan State College em Baltimore (janeiro de 1967), ambos anteriores ao lançamento do livro Black Power e reunidos na referida coletânea. Cf. CARMICHAEL, Stokely; HAMILTON, Charles V. Black Power: The Politics of Liberation. 2. ed. New York: Vintage Books, 1992; CARMICHAEL, Stokely. Stokely Speaks: From Black Power to PanAfricanism. 2. ed. Lawrence Hill Books, 2007. 
mundo. ${ }^{192} \mathrm{O}$ primeiro livro, originalmente intitulado Black Power: The Politics of Liberation in America, foi relançado em 1992 pela Vintage Books, uma subdivisão da editora original. Nesta versão mais recente, além de alterarem o título, os autores acrescentaram um curto prefácio denominado From the authors e dois novos posfácios, o primeiro elaborado por Stokely e o outro por Charles Hamilton. Stokely Speaks, por sua vez, reúne quinze artigos e discursos produzidos pelo ativista entre 1966 e 1971 organizados por Ethel N. Minor, ex-integrante da Nação do Islã, ativista do SNCC e sua secretária particular no decorrer de boa parte daquele período. ${ }^{193}$ Introduzido por Minor, o livro foi reeditado em 2007 pela Lawrence Hill Books e acrescido de dois novos prefácios assinados pelo ex-Pantera Negra Mumia Abu-Jamal e por Bob Brown, militante pan-africanista aliado de Carmichael em princípios da década de 1970.

Produzidas em meio à efervescência dos debates que circundavam as agendas políticas dos Movimentos pelos Direitos Civis e Black Power, tais obras compreendem as principais publicações do ativista acerca do tema. ${ }^{194}$ Para além da dinâmica nacional do movimento negro norte-americano, esses documentos abrangem, também, as filiações políticas e intelectuais estabelecidas pelo autor, em finais da década, com o pan-africanismo e as revoluções e lutas de libertação nacional desenvolvidas nos países do então chamado "Terceiro Mundo": África, América e Ásia. Assim, dentre as temáticas abordadas pelas obras, destacam-se: a denúncia do racismo no Sul dos Estados Unidos; as críticas do autor ao liberalismo norte-americano; sua oposição à presidência de Lyndon Johnson e à guerra ao Vietnã; reflexões acerca dos significados e proposições do Movimento Black Power; defesa da Revolução Cubana e das lutas vietnamitas, palestinas e africanas por emancipação política; apoio e, posteriormente, divergência com o

192 Segundo website da Penguin Random House, a multinacional atualmente conta com cerca de 250 selos e opera em mais de 20 países com uma publicação anual de cerca de 70.000 ebooks e 10.000 impressos. Disponível em: <https://www.penguinrandomhouse.com/about-us/our-story/>. Acesso em: 05 de jul. de 2018.

${ }^{193}$ Para um breve perfil de Ethel Minor, cf. CARSON, Clayborne. In Struggle. SNCC and the Black Awakening of the 1960s. Harvard University Press, 1981, p. 267-268.

${ }^{194}$ Para além dos livros mencionados, Carmichael foi autor, também, da já citada autobiografia Ready for the Revolution: The Life and Struggles of Stokely Carmichael. Publicado pela editora Scribner em 2003 em coautoria com Ekwueme Michael Thelwell - membro do SNCC e amigo pessoal de Carmichael dos tempos do NAG na Howard University - este livro foi iniciado antes do falecimento de Stokely em 1998 e completado postumamente por Thelwell a partir da edição e transcrição de depoimentos do ativista gravados em vida. Dessa forma, acreditamos que Ready for the Revolution compreende mais uma memória do ativista e, com isso, possui um lugar diferente neste trabalho que elegeu para análise documentos produzidos entre os anos de 1966 e 1971. CARMICHAEL, Stokely; THELWELL, Ekwueme M. Ready for the Revolution: The Life and Struggles of Stokely Carmichael (Kwame Ture). New York: Scribner, 2003. 
Partido dos Panteras Negras; adoção de uma agenda antirracista, anti-imperialista e anticapitalista radical; e a defesa do pan-africanismo revolucionário como principal front da luta negra no Atlântico.

Em suma, os livros abarcam as distintas fases e transformações atravessadas pela militância de Stokely Carmichael no decorrer da segunda metade da década de 1960 e início dos anos 1970. Nesse ambiente político efervescente, Carmichael buscou sintetizar sua posição - e a do SNCC do qual era então presidente - naquela que se tornaria sua mais conhecida obra, o livro Black Power: The Politics of Liberation.

\subsubsection{O livro Black Power: uma parceria entre intelectuais engajados}

"Este livro trata do porquê, do onde e da maneira pela qual os negros dos Estados Unidos devem se unir. É sobre os negros cuidando dos assuntos dos e para os negros. O que está em jogo é muito simples: se falharmos nisso, estaremos continuamente sujeitos a uma sociedade branca que não tem nenhuma intenção de desistir voluntária ou facilmente da sua posição de primazia e autoridade. Se formos bem sucedidos, nós exerceremos controle político, econômico e psíquico sobre nossas vidas. Nós também contribuiremos para o desenvolvimento de uma sociedade viável; em termos de ganho social último, não há nada de unilateral acerca do movimento para a libertação dos negros". ${ }^{195}$

Concebido entre setembro de 1966 e maio de 1967 - e, portanto, diretamente vinculado ao debate que circundava a militância negra do período - Black Power é o resultado de uma parceria intelectual entre Stokely Carmichael, autor de quatro capítulos da obra, e Charles Vernon Hamilton (1929 -), cientista político afro-americano, então professor da Lincoln University e coautor dos outros cinco capítulos que compõem o trabalho. ${ }^{196}$ Escrito, portanto, a quatro mãos, o livro alterna entre a eloquência e a crítica social marcantes da oratória do ativista caribenho e a linguagem mais contida e analítica, mas também engajada, característica do lugar acadêmico

195 "This book is about why, where and in what manner black people in America must get themselves together. It is about black people taking care of business - the business of and for black people. The stakes are really simple: if we fail to do this, we face continued subjection to a white society that has no intention of giving up willingly or easily its position of priority and authority. If we succeed, we will exercise control over our lives, politically, economically and physically. We will also contribute to the development of a viable larger society; in terms of ultimate social benefit, there is nothing unilateral about the movement to free black people". CARMICHAEL, Stokely; HAMILTON, Charles V. op. cit., p. XVXVI. Itálicos nossos.

${ }^{196}$ HAMILTON, Charles V.; HARRIS, Fredrick C. A Conversation with Charles V. Hamilton. Annual Review of Political Science, v. 21, jul. 2017, p. 24-25. 
ocupado por Hamilton.

Charles Vernon Hamilton foi um destacado professor universitário negro com passagens pela Roosevelt University, Loyola University, Chicago University (todas em Chicago), Tuskegee Institute (Tuskegee, Alabama) e, eventualmente, Columbia University (Nova York) onde tornouse um dos primeiros afro-americanos catedráticos de uma universidade da Ivy League ${ }^{197}$. Ele formava uma dupla curiosa com Stokely Carmichael. Por um lado, Hamilton era um intelectual progressista, politicamente ativo e familiarizado com o ativismo negro. Na década de 1950, sua formação e atuação profissional esteve diretamente vinculada ao surgimento do Movimento pelos Direitos Civis no qual participou e debateu ativamente em favor da integração racial no "Sul Profundo".

Naquele contexto, a postura dissidente e crítica do professor dentro e fora de sala de aula - similar à encontrada por Stokely em alguns dos seus mestres da Howard University - gerou atritos com administradores universitários, atraiu a vigilância do FBI e resultou até na demissão de Hamilton do Tuskegee Institute, histórica instituição de ensino superior negra fundada por Booker T. Washington em finais do século XIX. Contrário à cultura marcadamente conservadora de "acomodação" ao status quo racial predominante em Tuskegee, Hamilton não se abstinha de comentar e envolver-se com os temas tidos como "controversos" pelas autoridades universitárias. Assim, além de apoiar a mobilização por desobediência civil encabeçada por Martin Luther King, ele também engajou-se, a partir de 1960, nas ações organizadas pelo SNCC no Mississippi e no Alabama junto ao LCFO - Lowndes County Freedom Organization, onde conheceu Stokely Carmichael. ${ }^{198}$

Por outro lado, cabe destacar que havia importantes diferenças nos posicionamentos e nas trajetórias dos autores. Ainda que partilhassem preocupações, compromissos políticos semelhantes e as responsabilidades da escrita, Carmichael e Hamilton desempenhavam papéis

${ }^{197}$ A Ivy League designa um grupo composto por oito das mais reconhecidas e prestigiosas universidades privadas norte-americanas - Brown University, Columbia University, Cornell University, Dartmouth College, Harvard University, University of Pennsylvania, Princeton University e Yale University frequentadas, até então, quase exclusivamente pelas elites políticas e econômicas brancas do país. Nesses espaços, Hamilton constituiu uma rara exceção dentro do corpo docente destas instituições e percorreu uma trajetória de intelectuais negros pioneiros que remontava ao já citado W.E.B. Du Bois, o primeiro afro-americano a realizar, em 1895, um PhD na Harvard University.

${ }^{198}$ Sobre a trajetória de Charles V. Hamilton e sua participação na escrita do livro Black Power, cf. RICH, Wilbur C. From Muskogee to Morningside Heights. Political Scientist Charles V. Hamilton. Disponível em: <http://www.columbia.edu/cu/alumni/Magazine/Spring2004/hamilton.html $>$. Acesso em: 03 de julho de 2018. A este respeito ver, também, HAMILTON, Charles V.; HARRIS, Fredrick C. op. cit., p. 21-27. 
distintos dentro da parceria que originou sua mais célebre publicação. Doze anos mais velho, Hamilton pertencia a uma geração anterior àquela que, na segunda metade da década de 1960, estava na linha de frente do Movimento Black Power. Na época da publicação do livro, o cientista político aproximava-se dos quarenta anos de idade e, diferentemente do mais jovem Carmichael de vinte e seis anos, dedicava-se a uma consolidada carreira profissional no meio acadêmico, tendo concluído dois cursos superiores - Ciência Política e Direito - além de um mestrado e um doutorado. Em suas próprias palavras, Hamilton enxergava-se como um "acadêmico ativista", o que implicava certo distanciamento da militância em tempo integral a qual se dedicavam Carmichael e muitos outros ativistas negros da época. ${ }^{199}$

Portanto, aos olhos do público leitor, uma distinção entre as partes se fazia clara: era Stokely quem representava o ativismo radical, frequentemente gerava manchetes na imprensa e "escandalizava" a opinião pública com sua retórica inflamada ao passo que Hamilton, mais vinculado à cena acadêmica, aparecia em segundo plano. Contribuía para isso, ainda, o fato de que Hamilton era politicamente mais moderado e, diferentemente de Carmichael, jamais aderiu a perspectivas revolucionárias ou defendeu o recurso à luta armada. Pelo contrário, embora crítico ferrenho da acomodação de algumas lideranças negras tradicionais, no passar dos anos, o cientista político renegociou (e, pode-se dizer, fortaleceu), os laços com as pautas progressistas e as perspectivas reformistas que atravessaram e ultrapassaram a sua geração da década de 1950: a ênfase legalista da NAACP, a desobediência civil de Martin Luther King e, por último, a luta do SNCC por direitos civis e políticos no Sul rural.

Dessa maneira, não tardou para que, na década de 1970, as perspectivas dos autores se consolidassem em orientações políticas bastante distintas. Ao passo que Stokely passou a defender o pan-africanismo revolucionário em África, Hamilton trilhou um outro caminho como catedrático da Columbia University e consultor político do Partido Democrata para as eleições presidenciais de 1976. Por essa atuação, ele foi alvo de muitas críticas oriundas do movimento negro norte-americano ao propor a "desracialização" (deracialization) das campanhas democratas como maneira de tentar assegurar, diante de um cenário hostil à política negra, vitórias eleitorais a candidatos afro-americanos. ${ }^{200}$

\footnotetext{
${ }^{199}$ HAMILTON, CHARLES V.; HARRIS, Fredrick C. op cit., p. 23.

${ }^{200}$ Introduzido por Hamilton em 1973 durante uma reunião da NUL - National Urban League, o conceito de deracialization consistia numa estratégia eleitoral que propunha orientar as campanhas democratas para plataformas políticas, segundo os termos da época, "racialmente neutras". Para fazer frente à guinada
} 
Contudo, não obstante as distintas trajetórias perseguidas pelos autores em anos posteriores, à época da parceria editorial, as preocupações de Carmichael e Hamilton convergiam na busca por um terreno comum para o ativismo negro. Desta forma, como mencionado, é em Black Power: The Politics of Liberation, livro-manifesto do movimento Black Power, que os autores sistematizam uma análise crítica às reformas liberais operadas pelos Direitos Civis, elucidam suas proposições e, por fim, consolidam o seu projeto político para a luta negra contra o racismo nos Estados Unidos.

\subsection{O diagnóstico das relações raciais norte-americanas no livro Black Power}

"Em uma era de descolonização, pode ser proveitoso considerar o problema do negro norte-americano como um caso único de colonialismo, uma instância de imperialismo, um povo subdesenvolvido em nosso próprio meio". 201

$\mathrm{Na}$ obra, Carmichael e Hamilton partem de um diagnóstico dramático para denunciar o estado crítico em que se encontravam as relações raciais no interior da sociedade norte-americana da segunda metade da década de 1960. Alertando para a continuidade - senão o recrudescimento - das formas de opressão impostas aos afro-americanos mesmo após as Leis dos Direitos Civis, os autores apontam para o fato de que o racismo representava - e, é preciso destacar, ainda representa - um fenômeno muito mais pernicioso e resiliente do que, à primeira vista, julgava a opinião pública nacional.

Em Black Power: The Politics of Liberation, os autores mostram que, a despeito de apoiar-se em comportamentos e atitudes evidentes ao observador, o racismo não se resumia somente a manifestações isoladas e entre indivíduos. Ao contrário, estava enraizado e

conservadora da política norte-americana inaugurada pela eleição do Republicano Richard Nixon em 1968, Hamilton argumentava que candidatos progressistas deveriam atenuar suas propostas específicas ao público afro-americano - como, por exemplo, ações afirmativas e assistência social - a fim de aumentar as chances de elegerem suas candidaturas em um cenário político hostil. Segundo ele, naquele momento, os democratas deveriam elaborar uma plataforma mais "universal" - como a defesa do "pleno emprego" e de um plano nacional de saúde pública - que, mesmo despida de um recorte racial mais evidente, ainda assim contemplaria questões prementes às comunidades negras sem, contudo, alienar o eleitorado branco por completo. Com isso, o objetivo de Hamilton era atrair uma parte do voto dos brancos para garantir a eleição e a governabilidade de novos políticos afro-americanos. RICH, Wilbur C. op. cit., n.p.; HAMILTON, CHARLES V.; HARRIS, Fredrick C. op cit., p. 24-25.

201 "In an age of decolonization, it may be fruitful to regard the problem of the American Negro as a unique case of colonialism, an instance of imperialism, an underdeveloped people in our very midst". STONE, Isidor F. apud CARMICHAEL, Stokely; HAMILTON, Charles V., op. cit. p. 3. 
disseminado na sociedade, encontra(va)-se profundamente imbricado nas relações de poder do país, diretamente vinculado à (re)produção de padrões de desigualdade e privilégio racial "[...] com o propósito de subordinar um [determinado] grupo e manter o controle sobre este grupo". ${ }^{202}$ Tratava-se, em outras palavras, de um fenômeno de caráter total, sistêmico, um projeto de poder que se expressava não apenas em episódios violentos do segregacionismo sulista televisionados à audiência nortista, mas que englobava a sociedade norte-americana - suas práticas, o funcionamento de suas instituições, seu ordenamento político - como um todo:

"O racismo ocorre tanto às claras quanto de maneira dissimulada. Ele assume duas formas intimamente relacionadas: a ação individual de brancos contra negros e a ação da comunidade branca enquanto um todo. Denominamos essas formas de racismo individual e racismo institucional. O primeiro consiste em atos evidentes partindo de indivíduos que causam mortes, ferimentos ou a destruição violenta de propriedade. Este tipo pode ser gravado por câmeras de televisão; pode frequentemente ser observado no momento em que é perpetrado. O segundo tipo é menos evidente, muito mais sutil, menos identificável em termos de indivíduos específicos que cometem os atos. Mas não é menos destrutivo da vida humana. $\mathrm{O}$ segundo tipo se origina no funcionamento de forças estabelecidas e respeitadas na sociedade e, portanto, recebe muito menos condenação pública do que o primeiro". ${ }^{203}$

Com essa diferenciação, os autores introduzem, pela primeira vez, a tópica do "racismo institucional" em oposição ao "racismo individual" no vocabulário político contemporâneo e definem a discriminação racial como fator central à compreensão da realidade social norteamericana da época. Como aponta Silvio Luiz de Almeida, essa foi uma contribuição decisiva para demonstrar que "o racismo é um dos modos pelo qual o Estado e as demais instituições

${ }^{202}$ Segue a definição dos autores na íntegra: "By 'racism' we mean the predication of decisions and policies on considerations of race for the purpose of subordinating a racial group and maintaining control over that group". Itálico dos autores. CARMICHAEL, Stokely; HAMILTON, Charles V. op. cit., p. 3.

203 "Racism is both overt and covert. It takes two, closely related forms: individual whites acting against individual blacks, and acts by the total white community. We call these individual racism and institutional racism. The first consists of overt acts by individuals, which cause death, injury or the violent destruction of property. This type can be recorded by television cameras; it can frequently be observed in the process of commission. The second type is less overt, far more subtle, less identifiable in terms of specific individuals committing the acts. But it is no less destructive of human life. The second type originates in the operation of established and respected forces in the society, and thus receives far less public condemnation than the first type". CARMICHAEL, Stokely; HAMILTON, Charles V. op. cit., p. 4; Cf. ALMEIDA, Silvio Luiz de. O que é racismo estrutural? Belo Horizonte: Editora Letramento, 2018, p. 32. 
estendem o seu poder por toda a sociedade". ${ }^{204}$ Ou seja, que era (é) um fenômeno abrangente e arraigado: mesmo que cada vez mais "pessoas respeitáveis", nas palavras dos autores de Black Power, se eximissem de participação em episódios de violência racista, elas, coletivamente, beneficiavam-se - seja por omissão ou por interesse - dos privilégios que lhes eram assegurados por políticas, instituições e agentes excludentes. Assim, o "racismo individual pode [até] não tipificar a sociedade, [mas] o racismo institucional o faz". ${ }^{205}$

De toda forma, ancorado em séculos de escravidão e segregação racial, o racismo institucional do qual tratam os autores situava, em campos políticos opostos, brancos e negros, opressores e oprimidos, e, nos termos da época, "colonizadores" e "colonizados". Por meio desses antagonismos, os autores demarcavam o campo de atuação política da militância negra da época ao mesmo tempo que se abriam para a solidariedade com os colonizados e países periféricos do mundo. Nesse sentido, em tempos de lutas pela descolonização na África e na Ásia, Carmichael e Hamilton associavam a luta negra nos Estados Unidos às revoluções e processos de libertação do jugo europeu em voga no então chamado "Terceiro Mundo": África, América Latina e Ásia. Informados pelas reflexões e escritos anticoloniais do intelectual e revolucionário da Martinica Frantz Fanon - em particular pela célebre obra deste, Os Condenados da Terra ${ }^{206}$ - os autores e a militância negra do período percebiam a opressão racial a que os afro-americanos estavam sujeitos como uma forma de dominação colonial institucionalizada:

“[...] os negros neste país formam uma colônia e não é do interesse do

${ }^{204}$ ALMEIDA, Silvio Luiz de. op.cit. p. 34.

${ }^{205}$ Sobre o pioneirismo de Carmichael e Hamilton no emprego do termo "racismo institucional", conferir nota 12 de OMI, Michael; WINANT, Howard. op. cit., p. 17. Segue citação na íntegra: "Thus acts of overt, individual racism may not tipify the society, but institutional racism does - with the support of covert, individual atitudes of racism". CARMICHAEL, Stokely; HAMILTON, Charles V. op. cit., p. 5.

${ }^{206} \mathrm{Na}$ década de 1960, as obras de Frantz Fanon (1925-1961), psiquiatra e autor caribenho que dedicou sua vida à luta revolucionária Argelina por independência da França, foram instrumentais para que ativistas e cientistas sociais produzissem uma leitura político-identitária da opressão vivenciada pelos negros nos Estados Unidos. Em particular, Os Condenados da Terra - traduzido para o inglês e publicado nos Estados Unidos em 1965 - tornou-se referência obrigatória na maioria dos círculos militantes e intelectuais negros e, eventualmente, também conquistou influência entre a Nova Esquerda branca. Segundo estimativas do historiador William L. Van Deburg, até finais da década de 1970, cerca de 750,000 cópias do livro haviam sido vendidas, o que evidencia a enorme capilaridade das ideias de Fanon entre o público leitor norte-americano de esquerda. FANON, Frantz. Os Condenados da Terra. $3^{\mathrm{a}}$ reimpressão. Juiz de Fora: Editora UFJF, 2015 e VAN DEBURG, William L. op. cit., p. 60-61. Sobre o pensamento e a trajetória de Fanon, conferir também FAUSTINO, Deivison M. Frantz Fanon - Um revolucionário particularmente negro. São Paulo: Ciclo Contínuo Editorial, 2018. 
poder colonial libertá-los. Os negros são cidadãos dos Estados Unidos e detém, na maior parte, os mesmos direitos legais que outros cidadãos. No entanto, eles são como sujeitos coloniais em relação à sociedade branca. Portanto, o racismo institucional tem um outro nome: colonialismo". ${ }^{207}$

Mobilizando uma chave de leitura muito difundida entre a militância negra radical norteamericana da época, Carmichael e Hamilton identificavam as comunidades negras como “colônias internas" subordinadas aos desígnios da "América Branca". Naquele contexto, para os nacionalistas do Movimento Black Power, o emprego da analogia colonial oferecia um referencial político (framework), uma leitura fundamental que informava a resistência contra o sistema de opressão racial estrutural vivenciado pelos negros e por outros setores marginalizados nos Estados Unidos. Na visão de muitos destes grupos, significava dizer que, para alcançar seus objetivos, os afro-americanos deveriam - ou poderiam, dependendo da ênfase desejada - engajarse em uma luta de "libertação nacional" à maneira do realizado então pelos vietnamitas, argelinos ou chineses. Em outras palavras, a "colonização interna" imposta aos negros justificativa o separatismo e a "luta por libertação". Não por acaso, muitas das ações daqueles ativistas eram percebidas por eles próprios como expressões de um "nacionalismo negro". ${ }^{208}$

Portanto, no livro Black Power, a descrição das relações raciais norte-americanas em termos de um "colonialismo interno" não era fortuita. Ao contrário, tratava-se de um diagnóstico da situação das relações raciais central ao programa político que os autores procuravam esclarecer para o público leitor. Como discutido a seguir, através dela, Carmichael e Hamilton buscavam sintetizar as dimensões políticas, econômicas e psicológicas do racismo institucional em um único modelo explicativo que se opunha às perspectivas liberais vigentes durante os Direitos Civis em setores da política e da academia norte-americanas.

\subsection{1. "Governo indireto": a política do racismo institucional}

Em termos políticos, a "condição colonial” dos afro-americanos é caracterizada no livro pelo controle, organização e administração coercitiva do grupo oprimido por "forças externas" -

\footnotetext{
207 “[...] black people in this country form a colony, and it is not in the interest of the colonial power to liberate them. Black people are legal citizens of the United States with, for the most part, the same legal rights as other citizens. Yet they stand as colonial subjects in relation to the white society. Thus institutional racism has another name: colonialism". CARMICHAEL, Stokely; HAMILTON, Charles V. op. cit., p. 5.

${ }^{208}$ Ibidem, p. 6; OMI, Michael; WINANT, Howard. op. cit., p. 91-92.
} 
ou, como posteriormente popularizado pela retórica do Partido dos Panteras Negras, "invasoras" - que detém poder sobre ele. Nos Estados Unidos, argumentam os autores, a sociedade branca impunha sua vontade política sobre as comunidades negras de maneira semelhante ao realizado pelos europeus em possessões coloniais na África: isto é, através da instituição de um "governo indireto" responsivo aos interesses da "metrópole".

“Os sujeitos coloniais têm suas decisões políticas tomadas pelos mestres coloniais e essas decisões são transmitidas diretamente através de um processo de 'governo indireto'. Politicamente, as decisões que afetam vidas negras sempre foram feitas por pessoas brancas, pela estrutura de poder branco [white power structure]". ${ }^{209}$

No contexto colonial africano como um todo, as formas de "governo indireto" a que Carmichael e Hamilton faziam referência representavam uma das alternativas adotadas pelas potências europeias para exercer o controle sobre os extensos territórios adquiridos após a infame partilha da África na Conferência de Berlim (1895). ${ }^{210}$ Naquele momento, a implantação dos sistemas coloniais europeus tinha como ponto fraco a dificuldade logística das metrópoles de efetivamente ocupar as possessões coloniais no continente com amplos contingentes militares e civis. Devido a limitações demográficas, financeiras e à resistência dos africanos à dominação, em muitas localidades - especialmente em áreas interioranas de mais difícil acesso - o poder metropolitano frequentemente abdicou de exercer o "controle direto" sobre o território e sua população, optando por instituir conselhos e agentes "intermediários" atuando em seu benefício. Dessa forma, as metrópoles recorriam às instituições autóctones pré-existentes e ao recrutamento de chefes locais tanto para auxiliar na administração imperial quanto para "legitimar" esta nova ordem aos olhos dos africanos. ${ }^{211}$

209 "Colonial subjects have their political decisions made for them by the colonial masters, and those decisions are handed down directly or through a process of 'indirect rule'. Politically, decisions which affect black lives have always been made by white people - the white power structure". CARMICHAEL, Stokely; HAMILTON, Charles V. op. cit., p. 6-7.

${ }^{210}$ Complementar ao "governo indireto", a outra alternativa de controle empregado na África colonial era o "governo direto". Esta modalidade, que consistia na ocupação civil e militar ostensiva e na administração dos territórios coloniais por representantes dos Estados nacionais europeus, era mais comumente reservada a regiões estratégicas como áreas portuárias, aduanas e reservas minerais de grande importância econômica. De maneira geral, oscilando entre jugo indireto e direto, a "gestão [colonial] era um exercício de adaptação cultural e política necessariamente contingente, que dependia das situações e conjunturas locais". PARADA, Mauricio; BON MEIHY, Murilo Sebe; MATTOS, Pablo Oliveira de. História da África Contemporânea. Rio de Janeiro: Ed. Puc-Rio: Pallas, 2013, p. 43; 44-47.

${ }^{211}$ Ibidem, p. 39-43; VISENTINI, Paulo F.; RIBEIRO, Luiz D. T.; PEREIRA, Analúcia D. História da 
Evidentemente, esse arranjo ocorreu às custas da soberania que os africanos tradicionalmente dispunham sobre o território, seus costumes e suas atividades produtivas. Mesmo quando procurou-se "cooperação" política local, as sociedades africanas foram profundamente desestabilizadas por alterações nos seus sistemas judiciário, tributário e agrícola além da imposição do trabalho forçado - realizadas em benefício do poder colonial. Assim, com o crescimento da burocracia imperial até a Segunda Guerra Mundial, muitos chefes deixaram de desempenhar sua autoridade tradicional para se tornarem, em grande parte, agentes administrativos, "emissários" com atribuições, poderes e constrições ajustados à conveniência dos interesses metropolitanos. ${ }^{212}$

Para Carmichael e Hamilton, este quadro característico da política colonial europeia na África comportava paralelos ao vivenciado pelos negros no sistema político norte-americano da década de 1960. Nos Estados Unidos, denunciam os autores do livro Black Power, os brancos, à maneira dos colonizadores europeus, valiam-se do controle das instituições para manipular a população negra e outras minorias sociais a fim de preservar sua hegemonia. Em um contexto no qual as reivindicações e a representatividade afro-americana na política cresciam após a Lei do Direito de Voto de 1965, ocorria, segundo eles, a "assimilação" de um seleto número de negros “escolhidos a dedo", lembram os autores - nos quadros políticos e burocráticos. Cooptados pelo establishment branco Republicano ou, mais frequentemente, Democrata, esses "representantes", apontam os autores, eram “[...] somente tão poderosos quanto seus mestres permitissem". 213

Muitas vezes tímida, a atuação daqueles "líderes" cooptados limitava-se, portanto, a defender medidas vistas pelos autores como paliativas - verbas de assistência social, captação de empregos mal remunerados, acesso a cargos menores dentro da burocracia municipal, dentre outras - que, em última instância, pouco ou nenhum efeito tinham na resolução dos problemas concretos do eleitorado negro. Ao contrário, pelo tanto que concediam aos poderes instituídos, nada mais eram do que seus "emissários" trabalhando para a manutenção e legitimidade do status quo racial junto aos oprimidos:

"Em outras palavras, a estrutura do poder branco [white power structure] governa a comunidade negra através de negros locais que respondem aos líderes brancos do centro da cidade [downtown], à máquina política

\footnotetext{
África e dos Africanos. 3. ed. Petrópolis: Editora Vozes, 2017, p. 71-72.

${ }^{212}$ PARADA, Mauricio et al. op. cit., p. 46-50.

${ }^{213}$ CARMICHAEL, Stokely; HAMILTON, Charles V. op. cit., p. 10.
} 
branca, e não à população negra. Esses políticos negros não exercem poder efetivo. Não se pode esperar que eles farão exigências contundentes em nome de seus constituintes negros, pois eles não passam de fantoches. Eles colocam lealdade ao partido à frente da lealdade aos seus constituintes e, assim, anulam qualquer poder de barganha que a comunidade negra possa ter". 214

O resultado disso, apontam os autores a partir da análise de Kwame Nkrumah (líder da independência de Gana) no clássico Africa Must Unite (1963), era característico, também, do colonialismo britânico em distintas regiões da África Ocidental. ${ }^{215} \mathrm{Em}$ ambos os contextos, estabelecia-se um verdadeiro fosso que separava as massas populares dos "líderes cativos" - os "negros da casa", nas palavras de Malcolm X - pertencentes a uma classe média negra acomodada composta de professores, funcionários públicos, pequenos executivos, dentre outros, atuando em benefício do grupo branco hegemônico. ${ }^{216}$ Ao capitularem, nas palavras dos escritores, "à sujeição colonial em troca da segurança de alguns dólares e de um status duvidoso", os representantes da classe média negra, assim como os chefes africanos mencionados anteriormente, instrumentalizavam o "governo indireto" das comunidades negras pela sociedade

214 "In other words, the white power structure rules the black community through local blacks who are responsive to the white leaders, the downtown, white machine, not the black populace. These black politicians do not exercise effective power. They cannot be relied upon to make forceful demands in behalf of their black constituents, and they become no more than puppets. They put loyal to a party before loyalty to their constituents and thus nullify any bargaining power the black community might have". Ibidem, p. 10-11.

${ }^{215}$ Cabe lembrarmos ao leitor que, como mencionado no primeiro capítulo, Kwame Nkrumah foi um teórico e propositor do pan-africanismo cuja atuação e pensamento político influenciaram diretamente as perspectivas político-identitárias transnacionais adotadas por Stokely Carmichael em finais da década de 1960 e início da de 1970. Voltaremos a estas questões no capítulo 4, mas, por ora, interessa reforçar que a referência à Africa Must Unite é indicativo da influência de Nkrumah - e de outros teóricos anticoloniais do "Terceiro Mundo", como o citado Frantz Fanon - na construção da análise dos autores no livro Black Power: The Politics of Liberation.

${ }^{216}$ A crítica que Carmichael e Hamilton lançavam aos afro-americanos "cooptados" pelo "poder branco" era um tópico característico da retórica da militância negra radical, sobretudo entre os nacionalistas negros, popularizado algum tempo antes por Malcolm X. Em um dos seus mais conhecidos discursos, o Message to the grassroots (traduzido em alguns lugares como "Mensagem às bases"), X formulou a célebre dicotomia entre dois tipos, o "negro da casa" e o "negro do campo", como maneira de criticar lideranças negras integracionistas dos Direitos Civis e o seu projeto político moderado. O "negro da casa", dizia ele, correspondia ao escravo que, no tempo da escravidão, era subserviente ao seu senhor, identificava-se com os desejos deste e valorizava o status diferenciado que a proximidade à casa grande lhe conferia. Já o "negro do campo" - equivalente, no discurso de X, aos nacionalistas da década de 1960 - era o que mais sofria com as injúrias da escravidão, odiava o senhor e buscava, a todo momento rebelarse contra ele. Cf. X, Malcolm. Message to the Grassroots. In: ; BREITMAN, George (org.). Malcolm X Speaks. Selected Speeches and Statements. New York: Grove Press, 1990, p. 10-13. 
branca. $^{217}$

Por fim, um último aspecto da "política colonial" ao qual Carmichael e Hamilton fazem alusão é a criação de um sistema eleitoral restritivo desenhado para enfraquecer o capital político negro a nível local - condados, distritos, centros urbanos - onde, em diversos casos, a população afro-americana ali aglomerada constituía maioria numérica. Através de práticas eleitorais discriminatórias como gerrymandering ${ }^{218}$ e do emprego do sistema eleitoral majoritário (atlarge), ${ }^{219}$ ao invés da votação por distritos, a representatividade efetiva dos residentes negros era drasticamente reduzida pela máquina político-partidária.

O resultado, apontam os autores, era visível sobretudo na composição dos órgãos administrativos dos centros urbanos: na ilha de Manhattan (Nova York), onde sessenta por cento da população era afro-americana, os representantes negros eram extremamente escassos; em Detroit, onde praticavam-se eleições por sistema majoritário (at-large), apenas em 1957 um homem negro passou a integrar o Conselho Municipal; também em Los Angeles, onde foram criados distritos eleitorais muito amplos, o primeiro vereador negro (councilman) foi eleito somente em 1963. Assim, mesmo em grandes cidades onde a população negra era expressiva, a “estrutura de poder branco" conseguia privá-la de participação e manter o monopólio do poder

${ }^{217}$ No original: "It is crystal clear that most of these people have accommodated themselves to the racist system. They have capitulated to colonial subjugation in exchange for the security of a few dollars and dubious status. They are effectively lost to the struggle for an improved black position which would fundamentally challenge that racist system". CARMICHAEL, Stokely; HAMILTON, Charles V. op. cit., p. 14.

${ }^{218}$ Gerrymandering é um controverso e complexo expediente político ainda utilizado nos Estados Unidos por ambos os partidos que visa a redefinição dos limites de distritos eleitorais de modo a beneficiar numericamente determinado perfil de eleitor e de candidato (usualmente brancos) nas urnas. Historicamente, o gerrymandering, cujas origens remonta ao princípio do século XIX, passou a ser utilizado com frequência pelos segregacionistas após o fim da Reconstrução (1865-1877) como maneira de impedir o acesso de libertos ao voto antes que as leis Jim Crow entrassem em efeito. Somente em 1960, na decisão de Gommillion vs. Lightfoot, a Suprema Corte norte-americana julgou um caso flagrante de gerrymandering ocorrido em Tuskegee, Alabama, declarando a medida inconstitucional. Sobre o assunto, cf. KEYSSAR, Alexander. The Right to Vote. The Contested History of Democracy in the United States. Basic Books, 2000.

${ }^{219}$ No sistema eleitoral majoritário (at-large) os governantes são eleitos por uma maioria absoluta de votos para representar a totalidade da população de uma determinada região administrativa mais ampla municipal, estadual ou federal, por exemplo. Distingue-se, portanto, do voto distrital no qual eleitores, em geral residentes de um determinada subdivisão territorial - distrito, condado, etc - elegem governantes localmente para representá-los em outras instâncias administrativas. Nesse sentido, como apontado pelos autores, o emprego do sistema majoritário pode ser particularmente prejudicial à representatividade política de minorias sociais. Afinal, nesse cenário, a população negra encontra grandes dificuldades para eleger seus candidatos devido a vantagem numérica total que os candidatos brancos beneficiados por uma base eleitoral mais ampla detinham nas urnas. 
político. $^{220}$

\subsubsection{Exploração econômica: a "infraestrutura" colonial}

Se, de um lado, conforme revela a análise de Carmichael e Hamilton, o racismo operava através do controle das instituições norte-americanas pelos brancos com o intuito de assegurar sua hegemonia em relação aos afro-americanos; de outro, esta forma "política" da opressão racial assentava-se, ainda, sobre uma "infraestrutura" - uma base - econômica. Nesse sentido, uma outra importante premissa que compunha o quadro do "colonialismo interno" articulado pelos autores dizia respeito à existência de um violento sistema de "super-exploração" e coerção econômica voltado à expropriação dos recursos dos "colonizados" pelos "colonizadores". 221 Carmichael e Hamilton operavam, portanto, com categorias de análise da sua época oriundas do campo intelectual progressista que foram mobilizadas para analisar e propor soluções para a condição subalterna dos negros.

Retomando a analogia aos sistemas coloniais africanos, os autores apontam que o poder político colonial "andava de mãos dadas" com a privação e sujeição econômicas infligidas às comunidades afro-americanas por "agentes externos" enviados pelo capital e pelo governo federal. $^{222}$ Ao passo que, na África, o suposto "projeto civilizatório europeu" motivava-se, em realidade, pela pilhagem econômica do continente em favor das metrópoles imperiais; nas comunidades negras dos Estados Unidos uma dependência similar também se impunha recoberta,

\footnotetext{
${ }^{220}$ CARMICHAEL, Stokely; HAMILTON, Charles V. op. cit., p. 16.

${ }^{221}$ Embora o tom anticapitalista dos autores se faça presente no decorrer da obra, o conceito marxista da infraestrutura não é diretamente mobilizado por Carmichael e Hamilton no livro. Contudo, o seu emprego aqui busca traduzir o sentido geral transmitido pelos autores de Black Power de que a exploração econômica encontrava-se na "base" da "dominação colonial" imposta aos negros nos Estados Unidos. Novamente, é importante destacar que os autores partilham do diagnóstico de Frantz Fanon em $O s$ Condenados da Terra, para quem a opressão colonial - e suas consequências culturais, psicológicas, identitárias - ancorava-se em condições materiais de exploração muito bem definidas. Além disso, lembra o historiador Max Elbaum, a tese do "colonialismo interno" mobilizada por Carmichael, Hamilton e eventualmente parte da Nova Esquerda que em finais da década de 1960 se radicalizava; informava-se por uma leitura "terceiro-mundista" do marxismo vinculada às lutas anticoloniais dos "povos de cor" na África e na Ásia. Portanto, embora a referência não apareça na obra de maneira direta, Carmichael já dialogava, como veremos no capítulo 4, com o marxismo sobretudo em discursos contemporâneos ao livro Black Power posteriormente reunidos na coletânea Stokely Speaks. Cf. ELBAUM, Max. op. cit., p. 46. Sobre o "colonialismo interno", cf. OMI, Michael; WINANT, Howard. op. cit., p. 92; 177-178.

${ }^{222}$ CARMICHAEL, Stokely; HAMILTON, Charles V. op. cit., p. 16. A este respeito, conferir, também, discurso de Carmichael de outubro de 1966 na University of California em Berkeley: CARMICHAEL, Stokely. Berkeley Speech. In: op. cit., 2007, p. 48-49; 57.
} 
não raro, por um discurso pretensamente humanitário, filantrópico e assistencialista. Conforme argumentam, a máxima africana de que "os missionários vieram pelos nossos bens e não pelo nosso bem" aplicava-se, também, aos negros norte-americanos e configurava uma experiência de expropriação comum aos povos do continente e seus descendentes diaspóricos nos Estados Unidos:

"Os exploradores entram no gueto, sangram-no e deixam-no economicamente dependente da sociedade mais ampla. Tal como acontece com os missionários europeus, esses exploradores frequentemente colocam-se como 'amigos do negro', fingindo oferecer bens e serviços valiosos quando sua motivação primeira é o lucro pessoal e seu impacto direto é a manutenção do racismo. Muitas das agências de assistência social - públicas e privadas - frequentemente fingem oferecer serviços de 'auxílio'; em realidade, acabam criando um sistema que desumaniza o indivíduo e perpetua sua dependência. Consciente ou inconsciente, a atitude paternalista dessas agências não é diferente daquela de muitos missionários indo para a África". ${ }^{223}$

De fato, à época em que escreviam os autores, as condições econômicas dos afroamericanos pioravam progressivamente. Segundo apontam, na década de 1960, as disparidades entre negros e brancos norte-americanos agravavam-se, seguindo na contramão do boom econômico vivenciado pelo país após a Segunda Guerra Mundial. Enquanto os últimos, se comparados às décadas anteriores, presenciaram quedas nos índices de desemprego e aumento em suas rendas anuais médias - respectivamente, 4.1\% em 1966 e U\$5.130 para aqueles com ensino médio incompleto -; os afro-americanos e demais minorias não-brancas, por sua vez, atravessavam, segundo estimativas do Gabinete de Estatísticas do Trabalho (Bureau of Labor Statistics), por um quadro inverso - cerca de $8.3 \%$ e U\$5.020 para aqueles com ensino superior completo. Mais discrepante ainda eram os dados referentes à disparidade entre homens brancos e negros no cruzamento entre escolaridade e renda total: após toda uma vida inteira de trabalho, estimava-se que os primeiros receberiam cerca de U\$253,000 com apenas o ensino médio completo enquanto os segundos receberiam por volta de U\$246,000 com cinco ou mais anos

\footnotetext{
223 "Exploiters come into the ghetto from the outside, bleed it dry, and leave it economically dependent on the larger society. As with the missionaries, these exploiters frequently come as the 'friend of the negro', pretending to offer worthwile goods and services, when their basic motivation is personal profit and their basic impact is the maintenance of racism. Many of the social welfare agencies - public and private frequently pretend to offer 'uplift' services; in reality, they end up creating a system which dehumanizes the individual and perpetuates his dependency. Conscious or unconscious, the paternalistic attitude of these agencies is no different from that of many missionaries going to Africa". Ibidem, p. 17-18.
} 
completos no ensino superior. Ou seja, um trabalhador negro que possuía formação universitária ganhava menos que um branco que havia alcançado apenas a high school. ${ }^{224}$

À maneira das colônias africanas, afirmam os autores, os recursos econômicos da comunidade afro-americana eram expropriados por empresas, comerciantes e locatários brancos predatórios que se beneficiavam da fragilidade financeira dos residentes dos guetos e das comunidades rurais sulistas. Estas últimas eram caracterizadas, na visão dos autores, pela imposição de uma divisão do trabalho similar à encontrada nos sistemas coloniais europeus na África. Isto é, além de fornecerem a matéria-prima que abastecia a indústria metropolitana, cabia às colônias, ainda, o papel de consumir os produtos manufaturados pelos europeus a partir dos recursos anteriormente "pilhados". Nas plantations do Sul dos Estados Unidos, esta relação clássica da economia colonial reproduzia-se - ainda que "internamente" - na medida em que obrigava os trabalhadores agrícolas negros à condição de dependência com os proprietários de terra brancos:

"As comunidades negras dos Estados Unidos não exportam nada, exceto o trabalho humano [...]. [Contudo,] essencialmente, a colônia africana está vendendo seu trabalho; o produto em si não pertence aos 'sujeitos' porque a terra não é deles. Paralelamente, observemos os negros no Sul: eles cultivam algodão a U\$3,00 por um dia de dez horas de trabalho e a partir daí compram vestidos de algodão (além de alimentos e outros bens) de fabricantes brancos". 25

No contexto urbano, a situação também era crítica. Devido à inconstância no trabalho e à renda baixa, o comércio mais "respeitável" negava aos afro-americanos o crédito e os parcelamentos necessários ao consumo. Frequentemente, portanto, os negros tinham que escolher entre resignarem-se a preços e juros abusivos por produtos muitas vezes de baixa qualidade ou, então, abrir mão de itens de primeira necessidade. Barrados, em muitos casos, do acesso ao financiamento imobiliário e empresarial, os residentes dos guetos viam-se forçados a pagar aluguéis em média mais caros do que os dos brancos sem poder recorrer a uma fonte de renda

\footnotetext{
${ }^{224}$ Ibidem, p. 19-20.

225 "The black communities of the United States do not export anything except human labor. [...] Essentially, the African colony is selling its labor; the product itself does not belong to the 'subjects' because the land is not theirs. At the same time, let us look at the black people of the South: cultivating cotton at U\$3,00 for a ten-hour day and from that buying cotton dresses (and food and other goods) from white manufacturers". Ibidem, p. 6.
} 
autônoma proveniente de um "negócio próprio". ${ }^{226}$ Este grave quadro econômico, acrescido, ainda, das carências e da segregação nas escolas públicas disponíveis, tinha como consequência a reprodução de um "ciclo de pobreza" no seio das comunidades negras:

"De fato, a estrutura de poder branco colonial tem sido um adversário formidável. Ela tem perpetuado um ciclo vicioso - o ciclo da pobreza no qual às comunidades negras são negados bons empregos, o que resulta em uma baixa renda com a qual não conseguem obter uma boa educação para, então, conseguir bons empregos. [...] Os negros não qualificam para crédito nos lugares mais conceituados, então recorrem a comerciantes antiéticos que se aproveitam deles cobrando preços mais altos por produtos inferiores. Com isso, eles têm menos recursos para comprar em grandes quantidades, o que diminuiria os custos totais. Eles permanecem presos". 227

Assim, denunciam os autores, o racismo institucional impunha padrões políticos e econômicos de opressão muito bem definidos, sistêmicos, responsáveis por relegar os negros a uma condição subalterna na sociedade norte-americana. Contudo, ao discriminar racialmente os sujeitos, estes padrões não somente exprimiam práticas e processos "palpáveis" de exclusão, como também "intangíveis", vinculados à formação da "subjetividade e dos afetos", à(s) identidade(s) dos sujeitos racializados. ${ }^{228}$ Em outras palavras, para Carmichael e Hamilton, o "colonialismo" norte-americano tinha como último e devastador efeito a "alienação", a cisão psicológica dos afro-americanos.

\subsection{3. "Colônias internas": os guetos e a alienação psicológica do negro}

O diagnóstico das relações raciais norte-americanas traçado por Stokely Carmichael e Charles V. Hamilton no livro Black Power não se encerrava nos âmbitos político e econômico. Eles iam além, ampliando as consequências deletérias do modelo "colonial" para reiterar que a discriminação racial tinha, também, efeitos profundamente nocivos à subjetividade dos afroamericanos resultantes de um longo histórico de experiências desumanizadoras trazidas pela

${ }^{226}$ Ibidem, p. 20-22.

227 "Indeed, the colonial white power structure has been a most formidable foe. It has perpetuated a vicious - the poverty circle - in which black communities are denied good jobs, and therefore stuck with a low income and therefore unable to obtain a good education with which to obtain good jobs. They cannot qualify for credit at most reputable places; they then resort to unethical merchants who take advantage of them by charging higher prices for inferior goods. They end up having less funds to buy in bulk, thus unable to reduce overall costs. They remain trapped". Ibidem, p. 22-23.

${ }^{228}$ ALMEIDA, Silvio Luiz de. op. cit., p. 49. 
escravidão e pela segregação racial. Isto é, insidioso que era (é), o racismo constituía uma ideologia que perpassa(va) todo o imaginário social, moldando tanto práticas sociais concretas e suas manifestações institucionais quanto o "inconsciente" dos indivíduos brancos e negros. ${ }^{229}$

Aqui, novamente, a analogia à experiência colonial no Terceiro Mundo se fazia presente na análise proposta pelos autores. Influenciados pela leitura de Os Condenados da Terra de Fanon, Carmichael e Hamilton entendiam que a dominação "colonial" não somente despia os "colonizados" de poder político como também produzia um trauma psicológico naqueles que a vivenciavam. Segundo argumentavam, ao impor seus valores e sua visão de mundo pela força, o colonialismo distorcia, desfigurava, a história e a herança cultural de seus subordinados com o intuito de avançar o seu projeto de hegemonia. Em seu lugar, instituía o europeu/branco como o único modelo de humanidade possível ou reconhecível. Nessas circunstâncias, uma vez alienado do direito à política, à identificação com o próprio "povo" e cultura e, em última instância, à própria subjetividade; o "colonizado", cindido por esse processo terrível, terminava por internalizar o discurso de inferioridade a ele destinado pela "civilização" branca. ${ }^{230}$

"Em todos os momentos, então, o colonialismo tem como efeitos degradar e desumanizar o homem negro subjugado. As Escolas da Escravidão e Segregação, assim como a Escola do Colonialismo, ensinaram o subordinado a se odiar e a negar sua própria humanidade. A sociedade branca mantém uma atitude de superioridade e a comunidade negra sucumbiu com demasiada frequência a ela, permitindo assim que os brancos acreditassem na exatidão de sua posição. Os pressupostos racistas da superioridade branca foram tão profundamente enraizados na fibra da sociedade que embasam todo o funcionamento do subconsciente nacional". ${ }^{231}$

${ }^{229}$ Ibidem, p. 50-52.

${ }^{230}$ FAUSTINO, Deivison M. op. cit., p. 21-22; 55-56 e VAN DEBURG, William L. op. cit., p. 58-59. No pensamento fanoniano, a discussão acerca da "alienação" do sujeito negro em situação colonial é desenvolvida principalmente no livro Pele negra, máscaras brancas (1952) que, à época de seu lançamento, circulou de maneira limitada e terminou ofuscado pela repercussão estrondosa de $O s$ Condenados da Terra publicado alguns anos depois. Segundo aponta Lewis R. Gordon, foi somente na década de 1980 que o primeiro livro foi recuperado e tornou-se alvo de renovada atenção sobretudo por parte da crítica pós-colonial. Neste sentido, Stokely Carmichael e Charles V. Hamilton muito provavelmente desconheciam a existência de Pele negra, máscaras brancas e acessaram a temática em questão através de Os Condenados da Terra, única obra de Frantz Fanon que consta nas referências bibliográficas de Black Power: The Politics of Liberation. A esse respeito, cf. GORDON, Lewis R. Prefácio. In: FANON, Frantz. Pele negra, máscaras brancas. Salvador: EDUFBA, 2008, p. 12.

231 "At all times, then, the social effects of colonialism are to degrade and to dehumanize the subjected black man. White America's School of Slavery and Segregation, like the School of Colonialism, has taught the subject to hate himself and to deny his own humanity. The white society maintains an attitude 
No contexto norte-americano, em nenhum outro lugar a "alienação" social e psicológica dos afro-americanos discutida por Carmichael e Hamilton se fazia mais evidente do que em meio urbano. À época em que escreviam, cerca de $65 \%$ da população afro-americana estava concentrada em grandes cidades do Norte e do Oeste - e, em menor ênfase, do Sul - como Nova York, Chicago, Baltimore, Philadelphia, Detroit, Los Angeles, Washington. Nestes locais, apontam os autores, "os problemas da cidade e do racismo institucional" eram indissociáveis: desde a primeira metade do século XX, a comunidade negra sofria com rígidos padrões de segregação urbana que confinavam sucessivas levas de migrantes afro-americanos provenientes do Sul em guetos urbanos carentes de infraestrutura e amparo social mínimos. Vítimas da especulação imobiliária, do abandono do poder público, além de projetos predatórios de "renovação urbana"; os negros viam-se presos a "bolsões urbanos" de pobreza, núcleos superlotados onde condições adversas de vida se multiplicavam. ${ }^{232}$

Conforme apontam os autores, nos guetos constituía-se, então, um “[...] ciclo vicioso criado pela falta de moradia, empregos decentes e educação adequada" do qual seus residentes dificilmente conseguiam escapar. Uma vez presos ao "ciclo de pobreza" mencionado anteriormente, “[...] os negros começam a duvidar de si mesmos, do seu valor como seres humanos. O respeito próprio torna-se quase impossível". 233 O racismo institucional nos Estados Unidos, assim como o colonialismo europeu na África, lograva, portanto, incutir uma autoimagem negativa em suas vítimas.

Nesse ponto, a discussão da "alienação" psicológica do negro norte-americano desenvolvida por Carmichael e Hamilton no livro Black Power tinha como importante influência os trabalhos do psicólogo negro Kenneth Bancroft Clark (1914-2005), reconhecido pesquisador cujos estudos tratavam das relações entre racismo, pobreza e criminalidade no meio urbano. Anteriormente um integracionista convicto, em meados da década de 1960 Clark já figurava entre os primeiros proponentes da tese do "colonialismo interno" expressa no livro de sua autoria Dark Ghetto: Dilemmas of Social Power, de 1965. Informada por um cuidadoso estudo prévio das

of superiority and the black community has too often succumbed to it, thereby permitting the whites to believe in the correctness of their position. Racist assumptions of white superiority have been so deeply engrained into the fiber of the society that they infuse the entire functioning of the national subconscious". CARMICHAEL, Stokely; HAMILTON, Charles V. op. cit., p. 31.

${ }^{232}$ Ibidem, p. 149-151.

${ }^{233}$ Ibidem, p. 29; 155. 
condições socioeconômicas dos afro-americanos no bairro do Harlem - o relatório Youth in the Ghetto: A Study of the Consequences of Powerlessness, publicado em 1964 -, a obra constitui um trabalho seminal sobre o caráter sistêmico, cíclico, da discriminação racial e seus efeitos crônicos na vida do gueto. ${ }^{234}$

Leitores da obra de Clark, Carmichael e Hamilton mobilizam o relatório Youth in the Ghetto e o livro Dark Ghetto para apontar que a permanência de condições estruturais de exclusão no gueto - habitações precárias, índices de evasão e segregação escolar, desemprego, alta mortalidade infantil e materna, dentre outros - combinavam-se para desarticular a vida social, familiar e subjetiva das comunidades negras. Essa “infraestrutura" estabelecia a dependência econômica do gueto em relação aos programas de assistência social do governo federal (welfare) e fomentava os índices de "criminalidade" e dependência química que aviltavam parcela significativa dos seus residentes. Como consequência, a "alienação" no plano social traduzia-se para o plano subjetivo através internalização de sentimentos de "inferioridade", "raiva" e "desesperança" pelos afro-americanos do gueto. ${ }^{235}$

"Seres humanos que são forçados a viver em condições de gueto e cuja experiência cotidiana lhes diz que quase em nenhum lugar da sociedade eles são respeitados e concedidos a dignidade e cortesia concedidas a outros, começam a duvidar de seu próprio valor. [...] Essas dúvidas se tornam as sementes de um ódio pernicioso de si e de grupo, o complexo e debilitante preconceito do negro contra si mesmo. A preocupação de muitos negros com alisadores de cabelo, clareamento de pele e coisas

234 CLARK, Kenneth B. Ghetto negro: los dilemas del poder social. México: Fondo de Cultura Económica, 1968. Natural da Zona do Canal do Panamá, Clark formou-se, assim como Stokely Carmichael, na Howard University onde conheceu sua futura esposa e parceira de pesquisa, Mamie Phipps. Juntos, Clark e Phipps lideraram pesquisas inovadoras acerca dos impactos nocivos da discriminação racial na psicologia infantil. Em uma série de estudos tornados célebres pela sua relevância política à luta contra o racismo, o casal analisou a percepção que crianças negras tinham de bonecas brancas e negras, registrando suas reações. Os resultados do experimento apontaram que as crianças tendiam a caracterizar as bonecas negras como "feias" e a se identificarem com as brancas, que descreviam como "bonitas" e "agradáveis". Dessa forma, ao provarem os danos perversos da segregação racial na subjetividade das crianças negras em idade escolar, as conclusões de Phipps e Clark constituíram um recurso fundamental mobilizado pelo Ministro da Suprema Corte (Chief Justice) Earl Warren na decisão de Brown vs. Board of Education of Topeka (1954), que estabeleceu a inconstitucionalidade das leis Jim Crow nas instituições de ensino norte-americanas. Para uma discussão da obra e trajetória de Clark, cf. CURRIE, Elliott; GODDARD, Tim; MYERS, Randolph R. The Dark Ghetto revisited: Kenneth B. Clark's classic analysis as cutting edge criminology. Theoretical criminology, v. 19, n. 1, fev. 2015, p. 5-22; OMI, Michael; WINANT, Howard. op. cit., p. 35-36.

${ }_{235}$ CARMICHAEL, Stokely; HAMILTON, Charles V. op. cit., p. 155-160; CURRIE, Elliott; GODDARD, Tim; MYERS, Randolph R. op. cit., p. 9-13. 
semelhantes ilustra este aspecto trágico do preconceito racial americano os negros passaram a acreditar em sua própria inferioridade". ${ }^{236}$

Portanto, os guetos norte-americanos, "colônias internas" por excelência, eram analisados pelos autores de Black Power como produtos diretos do racismo institucional, vistos a partir de uma lógica sistêmica que tipifica(va) a exclusão racial. Isto é, suas mazelas não se tratavam, como já discutido, de uma questão de comportamentos, hábitos e atitudes inerentes aos indivíduos, mas de fenômenos que configuravam padrões de desigualdade e diferença racial tão arraigados a ponto de impactar o subconsciente dos sujeitos. Eram manifestações, de fato, "totais" no sentido pleno da palavra, pois infiltra(va)m-se nas mais distintas dimensões da vida coletiva nos Estados Unidos. Dado seu alcance, o racismo não havia sido e nem poderia ser plenamente superado por um movimento - os Direitos Civis - que visava reformar a nação a partir do seu interior. Para que isto ocorresse, os proponentes do Black Power tinham em mente transformações muito mais profundas.

\subsection{O ataque ao American Dream e a ruptura com os Direitos Civis na obra de Carmichael}

\section{e Hamilton}

"Não, eu não sou um americano. Eu sou um dos 22 milhões de negros que são vítimas do Americanismo, um dos 22 milhões de negros que são vítimas da democracia, que nada é além de hipocrisia disfarçada. Então, não estou aqui falando com vocês como um americano, um patriota, alguém que saúda e acena a bandeira - não, eu não. Estou falando como uma vítima deste sistema americano. Vejo a América através dos olhos da vítima. E eu não vejo nenhum sonho americano; vejo o pesadelo americano". 237

236 "Human beings who are forced to live under ghetto conditions and whose daily experience tells them
that almost nowhere in society are they respected and granted the ordinary dignity and courtesy accorded
to others will, as a matter of course, begin to doubt their own worth. [...] These doubts become the seeds
of a pernicious self-and group-hatred, the Negro's complex and debilitating prejudice against himself. The
preoccupation of many Negros with hair straighteners, skin bleachers, and the like illustrates this tragic
aspect of American racial prejudice - Negroes have come to believe in their own inferiority". CLARK,
Kenneth B. apud CARMICHAEL, Stokely; HAMILTON, Charles V. op. cit., p. 29 .
237 Segue, no original, o trecho do discurso O Voto ou a Bala (The Ballot or the Bullet), de 1964, no qual
Malcolm X contrapõe o "Pesadelo Americano" ao "Sonho Americano": "No I am not an American. I am
one of the 22 million Black people who are the victims of Americanism. One of the 22 million black
people who are victims of democracy, nothing but disguised hypocrisy. So I am not standing here
speaking to you as an American, or a patriot, or a flag saluter, or a flag-waver - no, not I. I am speaking as
a victim of this American system. And I see America through the eyes of the victim. I don't see any
American Dream. I see an American nightmare". X, Malcolm. The Ballot or the Bullet. In:
BREITMAN, George (org.). Malcolm X Speaks. Selected Speeches and Statements. New York: Grove 
Como vimos, Stokely Carmichael e Charles V. Hamilton veiculavam, no livro Black Power, o diagnóstico bastante difundido entre o ativismo negro radical da segunda metade da década de 1960 de que o Movimento pelos Direitos Civis havia, de fato, chegado ao seu limite. A despeito do êxito em desmontar os mecanismos legais da segregação racial, o movimento não havia modificado as estruturas políticas, econômicas e psicológicas reprodutoras do racismo na vida coletiva do país. Sob esta ótica, para os autores e parte da militância negra da época, os contornos da comunidade e identidade nacionais WASP (branca, anglo-saxã e protestante) ainda aparentavam ser tão estreitos e inalterados quanto haviam sido até então.

Apontando, na obra, o esgotamento do modus operandi liberal dos Direitos Civis, Carmichael e Hamilton lançavam um duro ataque ao nacionalismo cívico utilizado pelas lideranças negras moderadas como um quadro de referências para a luta antirracista. Em outras palavras, os autores recusavam a premissa à época amplamente compartilhada em círculos reformistas (brancos e negros) de que haveria uma contradição fundamental entre as práticas racistas da sociedade norte-americana e os valores fundacionais igualitários e pretensamente universais que compõem o "credo cívico" nacional (American Creed). Para os proponentes do Black Power, esse aparente paradoxo - esta visão de um "Dilema Americano" (American Dilemma) cunhado, à época, pelo sociólogo sueco Gunnar Myrdal (1898-1987) e mobilizado por setores mais moderados do movimento negro - representava, em realidade, uma falsa questão: o racismo não era uma "aberração", um fenômeno externo aos princípios nacionais mais básicos, mas algo que também os constituía. ${ }^{238}$

Press, 1990, p. 26.

${ }^{238}$ Ao tratarem de um "Dilema Americano", os autores faziam referência direta ao monumental estudo $\mathrm{An}$ American Dilemma, obra canônica acerca das relações raciais nos Estados Unidos publicada em 1944 sob coordenação do sociólogo sueco Gunnar Myrdal. Tomando, em definitivo, o lugar anteriormente ocupado pelo racismo biológico nas ciências sociais norte-americanas, An American Dilemma foi determinante em estabelecer o "tom" liberal (reformista) de oposição ao racismo durante o pós-Guerra e influenciou, na década seguinte, a atuação do Movimento pelos Direitos Civis. Fruto do trabalho de numerosos intelectuais brancos e negros do período financiado pela Carneggie Commission, o livro defende a existência de um descompasso entre os valores cívicos norte-americanos e a contínua opressão racial no país, propondo, como solução à "questão negra", estender as "benesses" constitucionais da nação aos negros. Sob esta ótica, o racismo era entendido por Myrdal em termos de "preconceito", como algo passível de ser reformado, fruto de práticas e atitudes individuais incongruentes com uma cultura política democrática mais ampla. De maneira geral, esta perspectiva encontrava fortes paralelos com as aspirações políticas do ativismo negro dos Direitos Civis do qual Stokely Carmichael fez parte nos primeiros anos da década de 1960. No entanto, como vimos anteriormente neste capítulo, ela se opunha à leitura que o Black Power tinha do racismo como um fenômeno estrutural. OMI, Michael; WINANT, Howard. op. cit., p. 31 - 
Desde os primóridos, apontava a perspectiva nacionalista negra mobilizada pelos autores, os Estados Unidos haviam se estabelecido como uma nação branca - além de masculina e proprietária de terras - às custas do imperialismo, da dominação racial e do extermínio de negros e indígenas. Exemplo claro disso, destacam os autores, a mesma Constituição que celebrava a "vida, liberdade e a busca pela felicidade" como direitos inalienáveis, prescrevia ao negro escravizado o status legal de propriedade:

"Alguns acreditam que existe um conflito entre o chamado credo cívico nacional [American Creed] $\mathrm{e}$ as práticas americanas. O credo supostamente contém considerações acerca da igualdade e liberdade ou, ao menos de igualdade de oportunidades, e justiça. O fato, é claro, é que estas são simplesmente palavras que originalmente sequer tinham a intenção de serem aplicadas aos negros: o Artigo I da Constituição [seção 2] afirma que o homem negro é três quintos de uma pessoa. [...] Não existe um 'Dilema Americano' ['American Dilemma'], não há um obstáculo moral, e os negros não devem basear suas decisões na suposição de que existe um dilema". ${ }^{239}$

Assim, contrapondo o nacionalismo cívico dos Direitos Civis ao nacionalismo negro mobilizado pelo Black Power, os autores alertavam para o fato de que não somente as instituições vigentes, mas também os "consagrados" valores norte-americanos conforma(va)m um modelo racista de sociedade e pressupunham uma narrativa da nação "exclusiva e excludente". ${ }^{240}$ Eles compunham, em outras palavras, uma narrativa supremacista branca que precisava ser completamente revista. Por isso, apontavam Carmichael e Hamilton, de nada valia ao ativismo negro recorrer aos mitos e símbolos nacionais articulados, por exemplo, no discurso "Eu tenho um Sonho" (I Have a Dream) proferido por Martin Luther King anos antes durante a Marcha Sobre Washington. Para eles, a visão de King tratava-se de um engodo, pois nenhuma das crenças nacionais reivindicadas pelo pastor batista fora originalmente concebida tendo os negros

35; 75-79. CARMICHAEL, Stokely; HAMILTON, Charles V. op. cit., p. 5. GERSTLE, Gary. op. cit., p. $193 ; 276$.

239 "Some believe that there is a conflict between the so-called American Creed and American practices. The Creed is supposed to contain considerations of equality and liberty, at least certainly equal opportunity, and justice. The fact is, of course, that these are simply words which were not even originally intended to have applicability to black people: Article I of the Constitution affirms that the black man is three-fifths of a person. [...] There is no 'American Dilemma', no moral hang-up, and black people should not base decisions on the assumption that a dilema exists". CARMICHAEL, Stokely; HAMILTON, Charles V. op. cit., p. 77.

${ }^{240}$ JUNQUEIRA, Mary A. Estados Unidos. Estado Nacional e Narrativa da Nação (1776-1900). São Paulo: Edusp, 2018, p. 48. 
em vista. Sugerem, ao contrário, que a experiência vivida do racismo impunha identificar - como havia feito Malcolm X - o "Sonho" pelo que de fato representava para os negros no país: um verdadeiro "Pesadelo Americano". 241

'Não nos disseram que o 'Sonho Americano' não havia sido projetado para pessoas negras. Que, embora hoje, para os brancos, o sonho possa parecer incluir os negros, ele não pode fazê-lo pela própria natureza do sistema político e econômico desta nação, que impõe o racismo institucional às massas negras, se não a todos os negros individualmente". ${ }^{242}$

Carmichael e Hamilton lançavam, portanto, um ataque frontal aos limites raciais historicamente construídos em torno da comunidade e identidade nacionais norte-americanas. Com isso, os proponentes do Movimento Black Power previam a necessidade de uma “reorientação" fundamental da nação, seus valores, identidade e instituições básicas responsáveis por sustentar a exclusão racial. Era hora, eles diziam, dos negros “[ [...] levantar[em] perguntas difíceis, questões que desafiam a própria natureza da sociedade" em favor de um novo marco civilizatório verdadeiramente humanista calcado na "[...] dignidade do Homem e não na santidade da propriedade privada", em um "povo livre" e não na "livre iniciativa". Em suma, era preciso, como sugerido por Stokely Carmichael em artigo anterior ao livro Black Power, refundar uma comunidade nacional livre da opressão racial em todos os seus níveis: "Para que o racismo morra, uma América totalmente diferente deve nascer". ${ }^{243}$

Dessa maneira, o movimento Black Power, vetor da mudança estrutural do racismo pretendida por Carmichael e Hamilton, recusava como suficiente o modus operandi mais amplo as instituições, os valores e, também, as estratégias - até então reivindicado pelo ativismo negro durante os anos dos Direitos Civis. Para eles, este movimento não exprimia o "tom de voz" da comunidade negra que se rebelava. Pelo contrário, aderindo a essas "regras pré-estabelecidas",

${ }^{241}$ X, Malcolm. The Ballot or the Bullet. In: ; BREITMAN, George (org.). op. cit., p. 26.

242 'We were not told that the 'American Dream' wasn't designed for black people. That while today, to whites, the dream may seem to include black people, it cannot do so by the very nature of this nation's political and economic system, which imposes institutional racism on the black masses if not upon every individual black". Itálico dos autores. CARMICHAEL, Stokely; HAMILTON, Charles V. op. cit., p. 51.

243 "Black people in the United States must raise hard questions, questions which challenge the very nature of the society itself: its long-standing values, beliefs and institutions" e "Reorientation means an emphasis on the dignity of man, not on the sanctity of property". [...] The creation of new values means the establishment of a society based [...] on "free people', not "free enterprise". CARMICHAEL, Stokely; HAMILTON, Charles V. op. cit., p. 41. Cf. também: "For racism to die, a totally different America must be born". CARMICHAEL, Stokely. Power and racism. In: op. cit., 2007, p. 23. 
limitava-se apenas a mediar os dois pólos em conflito (funcionando, em suas palavras, como uma buffer zone entre as comunidades negras e brancas), pois ajustava-se a uma audiência branca e de classe média da qual retirava apoio político, financeiro e legal para confrontar a segregação racial. Caracterizadas pelos autores como "retórica irrelevante", algumas pautas centrais que até então haviam organizado a luta negra contra o racismo - a saber, a busca pela integração racial do negro, a realização de alianças políticas interraciais e o emprego estratégico da desobediência civil não-violenta - deixavam de fazer parte do horizonte político da militância do Black Power. $^{244}$

\subsubsection{Os impedimentos à integração do negro à sociedade norte-americana}

O primeiro e, provavelmente o mais contundente, ponto de divergência de Stokely Carmichael, Charles V. Hamilton e do Movimento Black Power em geral com os Direitos Civis dizia respeito à questão da integração do negro nos Estados Unidos. À época em que escreviam os autores, o debate acerca desta questão no país ainda era profundamente atravessado, no pensamento sociológico mas também em setores moderados do movimento negro, por perspectivas reformistas para as quais os conflitos raciais seriam solucionados através da plena assimilação dos negros no melting pot - isto é, da sua integração à comunidade social, política e cultural norte-americana mais ampla.

Naquele momento, como indicado na seção anterior, cientistas sociais liberais do pósGuerra capitaneados por Gunnar Myrdal - e, posteriormente, por Nathan Glazer e Daniel Patrick Moynihan ${ }^{245}$, por exemplo - entendiam que as reformas inclusivas buscadas junto ao Governo

${ }^{244}$ CARMICHAEL, Stokely; HAMILTON, Charles V. op. cit., p. 50. Estas críticas dos autores ao Movimento pelos Direitos Civis como uma buffer zone, como um "apaziguador" dos conflitos, são integralmente retiradas de trechos anteriores do mencionado artigo What We Want de Stokely Carmichael posteriormente compilado na coletânea Stokely Speaks sob o título Power and Racism. A este respeito, comparar a página 50 citada do livro Black Power com CARMICHAEL, Stokely. op. cit., 2007, p. 17-18.

${ }^{245}$ Nathan Glazer (1923 - ) e Daniel Patrick Moynihan (1927-2003) foram importantes sociólogos que, na década de 1960, publicaram trabalhos influentes voltados tanto às questões da assimilação quanto do pluralismo cultural envolvendo distintos grupos "étnico-raciais" que compunham a sociedade norteamericana. Moynihan, em particular, ganhou grande visibilidade. Em meados da década, ele foi secretário assistente do trabalho durante a presidência de Lyndon Johnson (1963-1968) trabalhando ativamente no programa de Guerra à Pobreza instaurado pelo presidente. Contudo, Moynihan tornou-se conhecido pela publicação do controverso estudo The Negro Family: The Case for National Action, de 1965, no qual culpabilizava individualmente as vítimas do racismo pelos processos mesmos que as oprimiam. Segundo ele alegava - e por isso recebeu merecidas críticas de diferentes lados - famílias encabeçadas por mães negras solteiras, muitas delas beneficiárias de assistência social, não socializavam adequadamente a 
Federal garantiriam aos negros oportunidades análogas àquelas encontradas por outros grupos marginalizados que anteriormente haviam reivindicado - e, em certa medida, conseguido acesso à comunidade nacional. Nessa interpretação, uma vez que as barreiras formais que impunham a segregação racial fossem removidas, os negros, à maneira do que teria ocorrido com imigrantes irlandeses e, depois, judeus, poloneses, italianos, eslavos, dentre outros, chegados ao país em finais do século XIX e início do XX, estariam, grosso modo, em "igualdades de condições" em relação ao restante da sociedade. A partir de então, defendiam esses teóricos, caso obedecessem ao receituário de "trabalho duro", "paciência" e abnegação prescrito aos imigrantes pela ética protestante - um outro "mito" fundacional da narrativa da nação nos Estados Unidos os negros conquistariam seu devido "lugar ao sol" na sociedade norte-americana. ${ }^{246}$

Contrapondo-se a essa visão, a militância negra do Black Power passou, como vimos no princípio do capítulo, a preterir tal perspectiva assimilacionista dos Direitos Civis em favor de agendas políticas em torno do nacionalismo negro casadas, em alguns casos, à luta contra a opressão de classe. Definida em termos estritamente reformistas, a integração, pouco antes considerada um objetivo combativo e progressista, passava então a ser caracterizada pelo Black Power como uma pauta tímida, irrelevante e até contrária ao projeto de transformação radical do racismo estrutural. Ocorria, naquele momento, portanto, uma cisão decisiva no consenso liberal dominante nos Estados Unidos que, pelo menos desde a Segunda Guerra Mundial e desde as primeiras proposições de Gunnar Myrdal, havia aproximado as correntes reformistas das ciências sociais dos esforços mais amplos do movimento negro. ${ }^{247}$

Para Carmichael e Hamilton, não poderia ser diferente. Em sua visão, o prognóstico liberal de Myrdal e dos seus seguidores provava-se falacioso por distintas razões. Em primeiro lugar, argumentavam, essa leitura não atentava aos condicionantes estruturais do racismo apontados no diagnóstico de Black Power. Isto é, os liberais minimizavam as raízes mais profundas da opressão racial e, ainda, reduziam a singularidade da experiência negra no país

juventude masculina negra na ética do trabalho, o que, na visão de Moynihan, levava ao aumento do desemprego e da criminalidade nos guetos. Caminhando cada vez mais para a direita conservadora à medida que as décadas de 1960 e 1970 avançavam, as perspectivas difundidas por Glazer e Moynihan entraram em rota de colizão com o pluralismo e nacionalismo negro de militantes do movimento Black Power na academia, imprensa e política norte-americanas - como é o caso no livro de Carmichael e Hamilton que discutimos. Sobre o tema, cf. OMI, Michael; WINANT, Howard. op. cit., p. 29-46.

${ }^{246}$ Sobre as distintas correntes e interpretações que pautavam o debate acerca da integração racial e das relações raciais à época do Black Power, cf. Ibidem, p. 37; 41 e VAN DEBURG, William L. op. cit., p. 55-60.

${ }^{247}$ OMI, Michael; WINANT, Howard. op. cit., p. 29-32. 
àquela de imigrantes europeus brancos. A esse respeito, lembram os autores: "Quando algumas pessoas comparam o negro americano a 'outros grupos imigrantes' neste país, elas ignoram o fato de que $[\ldots]$ nenhum outro grupo minoritário neste país foi tratado como propriedade legal". ${ }^{248}$

Ademais, observada também à luz do "colonialismo interno" pensado por Carmichael e Hamilton, a agenda integracionista havia traído sua promessa principal de materializar a tão sonhada comunidade nacional interracial - a beloved community buscada pelo SNCC em seus anos iniciais - baseada em "igualdade de condições" para os negros. Ao contrário, argumentam, esta luta havia caminhado justamente em direção ao pólo oposto ao aprofundar a divisão de classe e a dependência "colonial" dentro das comunidades negras, contribuindo para assimilar apenas alguns poucos às custas da maioria dos afro-americanos excluídos. ${ }^{249}$

"Os objetivos dos integracionistas são objetivos de classe média articulados principalmente por um pequeno grupo de negros com aspirações ou status de classe média. Seu tipo de integração tem feito com que alguns negros 'bem-sucedidos' deixem a comunidade negra, esvaziando-a de potenciais lideranças e de know-how. [...] Estes negros cooptados - absorvidos por uma massa branca - não têm valor para as massas negras remanescentes. Eles tornam-se irrelevantes peças decorativas para a sociedade branca aplacar sua consciência". ${ }^{250}$

A pauta da integração comportava, ainda, um último problema para o Movimento Black Power: segundo evidenciado pelos autores no trecho acima, ela prescrevia aos afro-americanos, desde o princípio, uma "via de mão única", um caminho unilateral a ser seguido. Em outras palavras, tratava a assimilação a uma cultura branca e de classe média como algo desejável $a$ priori sem antes considerar as contribuições específicas dos negros ao todo social, além das suas características e heranças culturais próprias de grupo. Em ultima instância, para Carmichael e Hamilton, isso levaria ao "apagamento", à diluição no melting pot, de uma "integridade cultural" pretensamente intrínseca à comunidade afro-americana. Na sua análise, ao pressupor o branco

248 "When some people compare the black American to 'other immigrant groups' in this country, they overlook the fact that slavery was peculiar to blacks. No other minority group in this country was ever treated as legal property". CARMICHAEL, Stokely; HAMILTON, Charles V. op. cit., p. 25.

${ }^{249}$ Ibidem, p. 167-170; VAN DEBURG, William L. op. cit., p. 43-44.

250 "The goals of integrationists are middle-class goals, articulated primarily by a small group of Negroes with middle-class aspirations or status. Their kind of integration has meant that a few blacks 'make it', leaving the black community, sapping it of leadership potential and know-how. [...] Those token Negroes - absorbed into a white mass - are of no value to the remaining black masses. They become meaningless show-pieces for a conscience-soothed white society". CARMICHAEL, Stokely; HAMILTON, Charles V. op. cit., p. 53. 
como modelo a ser aspirado pelos sujeitos "coloniais", a integração provava-se não a condição da libertação negra, mas um "subterfúgio para a manutenção da supremacia branca". 251

“Como objetivo, a integração hoje trata da questão da negritude [blackness] não apenas de maneira irreal, mas também de maneira desprezível. Ela é baseada na completa aceitação do fato de que, para terem uma casa ou educação decente, os negros precisam se mudar para um bairro branco ou enviar seus filhos para uma escola branca. Isto reforça, entre negros e brancos, a ideia de que o 'branco' é automaticamente superior e o 'negro' é, por definição, inferior". ${ }^{252}$

Por fim, a revolta contra a assimilação configurava um ponto central da ruptura do Black Power com as perspectivas dominantes que pautavam o debate corrente acerca das relações raciais norte-americanas no movimento negro e nas Ciências Sociais da época. Da mesma forma que, àquela altura, parte significativa da militância negra distanciava-se do ideal de uma coletividade interracial de ativistas e simpatizantes, Carmichael e Hamilton também propunhamse a pensar a luta antirracista pelo viés do protagonismo e da agência política negra independente. Como consequência desse processo, os nacionalistas negros do Black Power desferiram um golpe certeiro no segundo apoio que sustentava o tripé político dos Direitos Civis: a prática de alianças políticas interraciais.

\subsection{2. "Cerrar as fileiras": a oposição do Black Power às alianças políticas interraciais}

Outro aspecto de grande discórdia entre os proponentes do movimento Black Power e os Direitos Civis dizia respeito à estratégia deste movimento de buscar o apoio político necessário à aprovação de suas pautas legais junto a setores liberais e sindicais brancos que orbitavam o Partido Democrata. Articuladas por Bayard Rustin e outros importantes estrategistas do

251 Interessante observar, novamente, as sobreposições que caracterizam os escritos de Stokely Carmichael. O argumento da integração como uma "via de mão única" e um "subterfúgio à supremacia branca" apresenta-se primeiro em Power and Racism e, depois, é transposto literalmente para Black Power. Cf. CARMICHAEL, Stokely; HAMILTON, Charles V. op. cit., p. 41; 54 e CARMICHAEL, Stokely. Power and Racism. In: op. cit., 2007, p. 23.

252 "'Integration' as a goal today speaks to the problem of blackness not only in an unrealistic way but also in a despicable way. It is based on complete acceptance of the fact that in order to have a decent house or education, black people must move into a white neighborhood or send their children to a white school. This reinforces, among both black and white, the idea that 'white' is automatically superior and 'black' is by definition inferior." CARMICHAEL, Stokely; HAMILTON, Charles V. op. cit., p. 54. Cf. também VAN DEBURG, William L. op. cit., p. 44. 
movimento, essas alianças interraciais com grupos e agentes brancos "simpáticos à causa negra" - dentre eles, quadros históricos do reformismo do New Deal mencionados no primeiro capítulo como o sindicalista Walter Reuther e o lobista Joseph Rauh Jr., por exemplo - eram duramente criticadas pelo espectro nacionalista negro do qual os autores do livro Black Power faziam parte. Segundo eles:

"Não vemos como os negros podem formar alianças efetivas com grupos que não estão dispostos a questionar e condenar as instituições racistas que exploram os negros; que não percebem a necessidade de - e não trabalham para - uma transformação fundamental. Os negros não podem se dar ao luxo de assumir que o que é bom para a América Branca é automaticamente bom para os negros". 253

Carmichael e Hamilton entendiam que os motivos que moviam os liberais a entrarem em coalizões não convergiam com a preocupação dos afro-americanos de livrarem-se das amarras mais profundas, estruturais do racismo; pelo contrário, por diversas ocasiões, haviam se mostrado divergentes e até antagônicos. Via de regra, a experiência pregressa de ativismo dos autores no SNCC lhes indicava que, contrariados os interesses dos seus "aliados" brancos, os "[...] direitos sociais e políticos dos negros têm sido e sempre serão negociados e descartados" ao sabor da

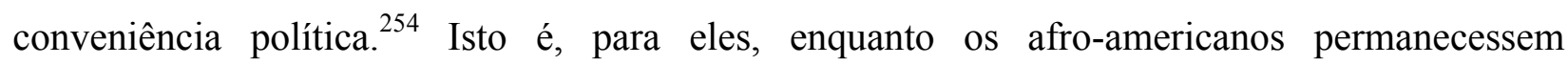
dependentes do capital político do establishment liberal, suas reivindicações mais fundamentais seriam preteridas, desrespeitadas, como vimos, por exemplo, com o MFDP - Mississippi Freedom Democratic Party na convenção nacional do Partido Democrata de 1964. Se a experiência traumática de Atlantic City provara algo era que, sob tais condições, a política de coalizões interraciais dos Direitos Civis estava irremediavelmente fadada ao fracasso:

"A lição, na verdade, ficou clara em Atlantic City. A principal moral desta experiência não foi simplesmente que a consciência nacional não era confiável, mas que, muito especificamente, os negros não podiam confiar em seus supostos aliados. Muitos líderes sindicais, liberais e dos direitos civis abandonaram o MFDP devido a laços estreitos com o Partido Democrata Nacional. [A escolha de] assentar o MFDP ao invés dos [delegados] 'regulares' [do Mississippi] produziria um deslocamento

253 "We do not see how black people can form effective coalitions with groups which are not willing to question and condemn the racist institutions which exploit black people; which do not perceive the need for, and will not work for, basic change. Black people cannot afford to assume that what is good for white America is automatically good for black people”. CARMICHAEL, Stokely; HAMILTON, Charles V. op. cit., p. 66.

${ }^{254}$ Ibidem, p. 63. 
de poder e ficou claro que, para combater o poder, era preciso ter poder. Os negros teriam que ter se organizado e obtido sua própria base de poder antes que começassem a pensar em coalizão com os outros. Contar com a ajuda de forças trabalhistas e liberais externas não foi um procedimento sensato". 255

Em grande medida, a inviabilidade das alianças preconizadas pelas lideranças dos Direitos Civis devia-se, para Carmichael e Hamilton, às desigualdades econômicas que distanciavam as partes sobretudo quando se tratava de associações interraciais envolvendo trabalhadores. Em sua análise, os autores recuperavam o longo histórico racista de setores do trabalhismo norte-americano como evidência adicional para o seu argumento de que, ao longo dos anos, "os interesses políticos e econômicos que levam os líderes brancos a entrarem nas coalizões [...] são diametralmente opostos aos interesses dos negros". ${ }^{256}$ Também no mundo do trabalho, a vulnerabilidade dos negros em face dos trabalhadores brancos e suas lideranças era sintomática do desequilíbrio de forças que pautava as relações estabelecidas entre as partes desde pelo menos o movimento populista ${ }^{257}$ de finais do século XIX, passando pelo New Deal dos anos

255 "The lesson, in fact, was clear at Atlantic City. The major moral of that experience was not merely that the national conscience was generally unreliable but that, very specifically, black people could not rely on their so-called allies. Many labor, liberal and civil rights leaders deserted the MFDP because of close ties to the national Democratic party. To seat the MFDP over the "regulars" would have meant a displacement of power, and it became crystal clear that in order to combat power, one needed power. Black people would have to organize and obtain their own power base before they could begin to think of coalition with others. To rely on the assistance of external, liberal, labor forces was not a wise procedure". CARMICHAEL, Stokely; HAMILTON, Charles V. op. cit., p. 96.

256 "The political and economic interests causing the white leaders to enter the coalition are clear. So is the fact that those interests are diametrically opposed to the interests of black people". CARMICHAEL, Stokely; HAMILTON, Charles V. op. cit., p. 71.

${ }^{257}$ Nos anos 1880, o movimento populista surgiu como uma reação às dificuldades financeiras que então afligiam os agricultores - em sua maioria, fazendeiros brancos pobres mas também arrendatários de terra negros - do Oeste e, principalmente, do Sul do país. Endividados junto às instituições de crédito e aos proprietários das terras em que trabalhavam, trabalhadores rurais uniram-se para formar um movimento que, por um momento, ameaçou perturbar as rígidas divisões raciais e de classe em vigor no campo. Em um período de fortes contestações contra os monopólios industriais e financeiros construídos pelo big business, os populistas organizaram-se sob uma ampla plataforma política que atacava a concentração de renda em distintas frentes: defendendo a regulamentação dos trustes, estabelecedo a propriedade pública do sistema ferroviário e das comunicações, reduzindo os juros, ampliando a educação pública e revendo leis de hipoteca em favor dos fazendeiros. Eventualmente, os populistas estabeleceram uma aliança com os Democratas para as eleições de 1896 na qual lançaram o líder Tom Watson como candidato do movimento à vice-presidência. Derrotados no pleito nacional, a tênue aliança entre agricultores brancos e negros se desfez e deu espaço, no Sul, à consolidação das leis segregacionistas Jim Crow que impuseram a supremacia branca na região. Àquela altura, muitos populistas brancos, dentre eles Watson, traíram suas posições "progressistas" anteriores - a defesa do voto negro e o combate ao crime de linchamento, por exemplo - e migraram ao campo político oposto, tornando-se ferrenhos defensores da segregação racial. 
1930 e chegando à década de 1960.

No caso do movimento populista - um amplo amplo levante de agricultores do Oeste e do Sul contrário ao monopólio financeiro e comercial exercido pelos bancos e grandes proprietários de terra - a vulnerabilidade dos negros em face dos trabalhadores brancos ficara clara. Para os autores de Black Power, o "fracasso" dos líderes populistas em sustentar a coalizão inicial bem como a posterior adesão de vários dos seus expoentes brancos mais notáveis (como, por exemplo, Tom Watson) ao regime segregacionista no Sul configuravam exemplos da instabilidade inerente às associações políticas interraciais. Uma vez mudado o cenário, continuavam Carmichael e Hamilton, os brancos, econômica e politicamente mais consolidados que os seus "aliados" negros, prontamente abandonariam seus compromissos anteriores e partiriam à defesa dos seus interesses exclusivos: "[...] os brancos - sejam populistas, republicanos ou democratas - sempre tiveram seus próprios interesses em mente. $\mathrm{O}$ negro nada mais era do que uma bola do jogo político a ser jogada e chutada de um lado para o outro segundo a conveniência daqueles cuja condição era mais estável". ${ }^{258}$

Similarmente, denunciavam Carmichael e Hamilton, também no movimento sindical organizado o operariado branco por diversas ocasiões mostrara-se negligente e comprometido com a discriminação racial existente em seu meio. A esse respeito, os autores lembram que, durante o New Deal e a passagem do Wagner Act em 1935 - estabelecendo o direito dos sindicatos se organizarem e negociarem coletivamente com o patronato - os sindicatos majoritária ou exclusivamente brancos fortaleciam-se economicamente às custas dos operários negros (em sua maioria não sindicalizados) que sofriam com uma piora sensível nas suas condições de trabalho e na representatividade política das suas categorias. ${ }^{259}$

Sobre o período em questão, cf. SHAWKI, Ahmed. Libertação negra e socialismo. São Paulo: Ed. Sundermann, 2017, p. 97-104 e JUNQUEIRA, Mary A. op. cit., p. 133-139.

258 "The history of the period tells us that the whites - whether Populists, Republicans or Democrats always had their own interests in mind. The black man was a little more than a political football, to be tossed and kicked around at the convenience of others whose position was more secure". CARMICHAEL, Stokely; HAMILTON, Charles V. op. cit., p. 69-70.

${ }_{259}$ Ibidem, p. 72-73. É importante notar, contudo, que, para esta análise, Carmichael e Hamilton não levaram em consideração o impacto de outros importantes obstáculos e retrocessos enfrentados pelo movimento sindical norte-americano como um todo nos primeiros anos após a Segunda Guerra Mundial e, também, durante a repressão macartista dos anos 1950. Aqui, em particular, destacamos uma omissão significativa dos autores: a passagem, a despeito do veto presidencial de Harry Truman, do Taft-Hartley Act. Sancionado pelo Congresso em 1947, a medida emendava as provisões anteriores do Wagner Act só que, desta vez, em benefício da classe empresarial. Após sua aprovação, o Taft-Hartley Act passou a proibir uma série de práticas trabalhistas de organização e reivindicação políticas asseguradas pela 
Exemplo disso, a AFL - American Federation of Labor, fundada em 1886 e durante décadas a maior central sindical do país, impedia deliberadamente a filiação de trabalhadores negros de distintos ofícios como impressores, bombeiros, pedreiros, eletricistas. Em alguns casos, barrado o acesso à contratação e à representação trabalhista adequadas, o desemprego entre os negros manteve-se duas vezes maior do que entre os brancos sindicalizados. Esse quadro pouco mudou mesmo após a fundação do CIO - Congress of Industrial Organizations, central sindical aberta aos afro-americanos criada em 1935 por liberais dissidentes da AFL. ${ }^{260}$ Aos olhos dos proponentes do Black Power, a mesma ordem econômica discriminatória continuava a permear o mundo do trabalho: "Embora o CIO se ocupasse de uma variedade de assuntos - comércio exterior, taxas de juros e, em certa medida, direitos civis - ele também nunca questionou seriamente os fundamentos racistas da sociedade". ${ }^{261}$

De fato, conforme aponta o historiador Flávio Limoncic, essa dinâmica perdurou nos anos do pós-Guerra. Àquela altura, convocando os trabalhadores (sobretudo os brancos) a participarem do "grande consenso americano" baseado na valorização salarial e no consumo de bens duráveis, o sindicalismo organizado dava sinais de um conservadorismo crescente. Unificada em uma só central a partir de 1955, a AFL-CIO, tornava-se, então, apenas mais um grupo "interessado na manutenção de uma ordem social que lhe trazia ganhos materiais e simbólicos" à revelia do trabalhador negro deixado de fora dos benefícios negociados junto às empresas. ${ }^{262}$

Atento a tal quadro, em 1959 o já mencionado líder trabalhista negro A. Philip Randolph fundou a NALC - Negro American Labor Council, organização sindical negra cujo objetivo era organizar os operários afro-americanos excluídos pela AFL-CIO. Naquele momento, ponderam Carmichael e Hamilton, "ao menos alguns trabalhadores negros finalmente aceitaram a realidade de que eles precisavam ter os seus próprios representantes negros se quisessem que suas demandas fossem ao menos colocadas - quem dirá atendidas". Contudo, aos olhos dos militantes

legislação anterior como greves não-autorizadas, boicotes, piquetes, dentre outros. LIMONCIC, Flávio. Os Inventores do New Deal. Estado e sindicatos no combate à Grande Depressão. Civilização Brasileira, 2009, p. 237.

${ }^{260}$ CARMICHAEL, Stokely; HAMILTON, Charles V. op. cit., p. 73. Para uma discussão das tensões entre a AFL e do CIO, cf. LIMONCIC, Flávio. op. cit., p. 187-204.

${ }^{261} \mathrm{Na}$ integra: "With the founding and development of mass industrial unionism under the Congress of Industrial Organizations (CIO), we begin to see a slight change in overall union orientation. The CIO was interested in a wide variety of issues - foreign trade, interest rates, even civil rights issues to an extent but it too never seriously questioned the racist basis of the society". CARMICHAEL, Stokely; HAMILTON, Charles V. op cit., p. 64.

${ }^{262}$ LIMONCIC, Flávio. op. cit., p. 241-242. 
do Black Power, também o NALC, um dos grupos idealizadores da Marcha Sobre Washington de 1963, era atravessado por limitações. Vinculado à NAACP, o grupo não dispunha de uma base organizacional e financeira própria que lhe conferisse autonomia de ação e barganha junto às demais forças políticas. Consequentemente, permanecia atado às pautas e objetivos liberais que sujeitavam o movimento negro a uma relação de dependência em relação ao establishment liberal Democrata. $^{263}$

Conquanto justa em muitos aspectos, cabem algumas ressalvas à análise dos autores. As críticas de Carmichael e Hamilton ao movimento sindical precisam ser compreendidas à luz das disputas e rivalidades políticas no campo das esquerdas norte-americanas que dividiam nacionalistas negros e marxistas de distintos matizes quanto a ênfase e a forma da luta contra a opressão. Por isso, o destaque dado pelos autores aos populistas e à AFL-CIO era significativo tanto pelo que revelava quanto pelo que omitia: filiando-se a uma perspectiva nacionalista negra contrária à pratica de alianças interraciais, a análise dos autores não fazia referência, por exemplo, à experiência da IWW - Industrial Workers of the World, expressiva organização interracial de orientação socialista que, nos anos 1910 e 1920, opunha-se à AFL e militava ativamente contra a discriminação racial no movimento trabalhista. Tampouco citava as contribuições do Partido Comunista dos Estados Unidos em defender e organizar, principalmente nos anos 1930, trabalhadores negros até então não sindicalizados. Em suma, esses e outros silêncios sugerem, sobretudo, uma escolha política dos autores indicativa da orientação nacionalista negra que imprimiam em seu projeto político para o movimento Black Power. ${ }^{264}$

De toda forma, após décadas de frustrações e dificuldades vivenciadas pelo ativismo negro junto às forças reformistas da sociedade norte-americana, os autores de Black Power viam as alianças políticas interraciais com enorme desconfiança. Propondo que a militância negra rompesse com seus antigos aliados liberais e trabalhistas dos Direitos Civis, Carmichael e Hamilton entendiam que os afro-americanos precisavam primeiro fortalecer-se enquanto grupo, construir "bases de poder" autônomas, para somente então avaliar a possibilidade de coalizões políticas. Nesse sentido, segundo eles, o Black Power baseava-se na premissa fundamental de que

\footnotetext{
263 "Some black workers, at least, finally accepted the reality that they had to have their own black representatives if their demands were to be made - not to mention being met". CARMICHAEL, Stokely; HAMILTON, Charles V. op cit., p. 73. Sobre o NALC, cf. website do Martin Luther King Jr. Research and Education Institute. Disponível em: $<$ https://kinginstitute.stanford.edu/encyclopedia/negro-americanlabor-council-nalc>. Acesso em: 28 de out. 2018.

${ }^{264}$ Sobre a atuação do IWW e do Partido Comunista, cf. SHAWKI, Ahmed. op. cit., p. 152-156; 167-168.
} 
“antes de um grupo ingressar na sociedade mais ampla, ele deve primeiro 'cerrar suas fileiras' [close ranks]". ${ }^{265}$ Como veremos adiante, essa busca por autonomia constituía um aspecto central do programa político-identitário que os autores traçavam para o movimento negro da segunda metade da década de 1960.

\subsubsection{Black Power: a não-violência dos Direitos Civis em xeque}

Um último ponto da ruptura estabelecida pelos proponentes do Black Power com os Direitos Civis girava em torno da crescente frustração da militância negra com a "ineficácia" da estratégia da desobediência civil não-violenta em conter o avanço da violência contra ativistas e comunidades negras em todo o país. Como vimos, uma vez confrontadas pela atuação de ativistas do CORE, SNCC, SCLC e outros grupos, bandos de "justiceiros" brancos e organizações terroristas como a Ku Klux Klan frequentemente recorriam a intimidações e crimes horrendos como forma de impor o regime segregacionista nos estados do Sul. Ao mesmo tempo, nos estados do Norte e Oeste, residentes dos guetos lida(va)m com a presença constante da violência policial com a qual o Estado sanciona(va) a prática de agressões, prisões injustificadas, encarceramento e assassinatos contra a população afro-americana e seus representantes.

Frente a esta dura realidade, a despeito dos riscos envolvidos, ativistas dos Direitos Civis recorreram, em diversas ocasiões, à desobediência civil não-violenta como um recurso pacífico mas não passivo - de resistência política. Naquele contexto, como discutimos no primeiro capítulo, a adesão a esta filosofia de matriz gandhiana constituía um aspecto ideológico central das marchas, boicotes, sit-ins e freedom rides concebidos por lideranças como Martin Luther King, Bayard Rustin e, claro, numerosos estudantes-ativistas do SNCC e do CORE que arriscavam seus corpos na linha de frente da luta contra o racismo. ${ }^{266}$

Por isso, a partir de meados da década de 1960, após anos de abusos e experiências traumáticas, a "não-violência" perdia credibilidade aos olhos da militância negra. Para muitos, a paciência havia acabado. À medida que os guetos urbanos atravessavam por numerosos levantes

265 "The concept of Black Power rests on a fundamental premise: Before a group can enter the open society, it must first close ranks". CARMICHAEL, Stokely; HAMILTON, Charles V. op cit., p. 44.

266 A esse respeito, cf. novamente MARABLE, Manning. Race, Reform, and Rebellion: The Second Reconstruction and Beyond in Black America, 1945-2006. 3. ed. Jackson: University Press of Mississippi, 2007; SITKOFF, Harvard. The Struggle For Black Equality, 1954-1992. New York: Hill and Wang, 1993 e CARSON, Clayborne. In Struggle. SNCC and the Black Awakening of the 1960s. Harvard University Press, 1981. 
e que o Movimento Black Power e a resistência à Guerra no Vietnã se fortaleciam, projetos mais radicais de luta política ganhavam terreno dentro das esquerdas norte-americanas. Naquele momento, diversos ativistas negros - dentre eles, Stokely Carmichael - e organizações como o Partido dos Panteras Negras passaram a endossar abertamente o direito à auto-defesa armada anteriormente recusado pelos Direitos Civis ou então praticados de maneira "clandestina" por organizações como o já citado Deacons for Defense and Justice e o RAM - Revolutionary Action Movement. ${ }^{267}$ Em sua visão, não era mais possível que os negros confiassem sua integridade física a uma sociedade construída sobre um longo histórico de violência racial:

"A política do Dr. [Martin Luther] King era que a não-violência conquistaria ganhos para os negros nos Estados Unidos. O ponto de partida dele era que, se você for não-violento, se sofrer, seu oponente verá seu sofrimento e se sensibilizará a mudar. Isto é muito bom. No entanto, ele só fez uma suposição falaciosa. Para que a não-violência funcione, seu oponente deve ter uma consciência. Os Estados Unidos não têm consciência". 268

Tratando do tema em Black Power e em Stokely Speaks, Carmichael e Hamilton eram taxativos ao afirmar que os negros podiam e deveriam recorrer às armas ou, como na máxima de Malcolm X, a "quaisquer meios necessários"269 para garantir a segurança de suas famílias e

267 O RAM foi uma organização nacionalista negra revolucionária fundada em 1962 pelos militantes negros Max Stanford e Donald Freeman. Inspirado pela atuação do ativista Robert F. Williams, radical negro que advogava a autodefesa armada no Sul do país em pleno movimento dos Direitos Civis, o RAM combinava a condenação de Malcolm X à "América Branca" a uma leitura terceiro-mundista da opressão sofrida pelos negros nos Estados Unidos. Um dos propositores iniciais da tese do "colonialismo interno", o RAM enxergava a luta contra o racismo no país como parte de um esforço mais amplo de libertação anticolonial no "Terceiro Mundo". Difundindo textos-chave de revolucionários do período (Frantz Fanon, Mao Tsé-Tung, Che Guevara), o grupo desempenhou um papel importante na formação política de futuros quadros do Movimento Black Power como, por exemplo, os Panteras Negras Bobby Seale e Huey Newton. Sobre o RAM, cf. BLOOM, Joshua; MARTIN Jr., Waldo E. op. cit., p. 32 e KELLEY, Robin D.G. "Roaring from the east": Third World Dreaming. In: . Freedom Dreams. The Black Radical Imagination. Boston: Beacon Press, 2002, p. 60-109.

${ }^{268}$ Transcrição de fala de Stokely Carmichael: "Dr. King's policy was that nonviolence would achieve the gains for black people in the United States. His major assumption was that if you are nonviolent, if you suffer, your oponente will see your suffering and will be moved to change his heart. That's very good. He only made one fallacious assumption. In order for nonviolence to work, your oponente must have a conscience. The United States has none". Fonte: The Black Power Mixtape, 1967-1975. Direção: Göran Olsson. Produção: Annika Rogell, Joslyn Barnes, Danny Glover e Axel Arnö. Suécia e Estados Unidos: Story AB; Sveriges Television (SVT); Louverture Films, 2011. (6m20s-7m). Disponível em $<$ https://www.youtube.com/watch?v=6bryh0IFMhg >. Acesso em: 10 de agosto de 2018.

${ }^{269}$ Esta máxima ("by any means necessary", em inglês) era recorrentemente mobilizada por Malcolm X em seus discursos. A partir deles, tornou-se lema, "palavra de ordem", para a militância radical do Black 
comunidades contra violência e intimidações racistas: "Do nosso ponto de vista, turbas brancas e justiceiros noturnos devem ser forçados a compreender que os seus dias de violência gratuita acabaram. Os negros devem e precisam responder à altura". ${ }^{270}$

Em outras palavras, para os autores e a militância do Black Power, a não-violência havia se mostrado por demais subserviente e conciliatória com os brancos. Uma vez confrontados com ameaças à sua integridade física, os negros precisavam se afirmar, se necessário fosse, pela força e não apelar à consciência ou a uma pretensa moralidade da nação como, em sua visão, faziam as lideranças dos Direitos Civis. Frente a conivência do Estado e da sociedade com a violência e exclusão raciais, a autodefesa justificava-se como direito legítimo - e até constitucional, conforme colocavam os Panteras Negras - dos oprimidos: "se uma nação falha em proteger seus cidadãos, então esta [mesma] nação não pode condenar aqueles que tomarem esta tarefa para si”. Por isso, Carmichael defendia que, em última instância, “[...] a responsabilidade pelo emprego da violência por homens negros, seja em autodefesa ou iniciada por eles, reside na comunidade branca". 271

"Aqueles de nós que defendem o Black Power estão bastante seguros de que uma abordagem 'não-violenta' dos direitos civis é uma abordagem da qual os negros não podem dispor e um luxo que os brancos não merecem. É cristalino para nós - e também o deve ser para a sociedade branca - que não pode haver ordem social sem justiça social. As pessoas brancas precisam entender que devem parar de provocar os negros ou os negros vão reagir!". 272

Power. Para um uso deste termo na obra de Carmichael e Hamilton, cf. CARMICHAEL, Stokely; HAMILTON, Charles V. op. cit., p. 185 : "Eles [os negros] não serão impedidos em seu objetivo de conquistar a dignidade, conquistar sua parcela de poder e, de fato, de tornarem-se seus próprios homens e mulheres - neste tempo e nesta terra - por quaisquer meios necessários".

270 "From our viewpoint, rampaging white mobs and white night-riders must be made to understand that their days of free head-whipping are over. Black people should and must fight back". CARMICHAEL, Stokely; HAMILTON, Charles V. op.cit., p. 52-53.

271 "If a nation fails to protect its citizens, then that nation cannot condemn those who take up the task themselves". Ibidem, p. 52-53. "Responsibility for the use of violence by black men, whether in selfdefense or initiated by them, lies with the white community". Cf. CARMICHAEL, Stokely. Power and Racism. In: op. cit., 2007, p. 21 e VAN DEBURG, William L. op. cit., p. 44-45.

272 "Those of us who advocate Black Power are quite clear in our own minds that a "non-violent" approach to civil rights is an approach black people cannot afford and a luxury white people do not deserve. It is crystal clear to us - and it must become so with the white society - that there can be no social order without social justice. White people must be made to understand that they must stop messing with black people, or the blacks will fight back!”. Itálico dos autores. CARMICHAEL, Stokely; HAMILTON, Charles V. op.cit., p. 53. 
Dessa forma, nos turbulentos anos do Black Power, a recusa da desobediência civil nãoviolenta em favor de um posicionamento negro mais combativo certamente traduzia uma mudança significativa no "tom" político de parte da militância e comunidade negras. De fato, para muitos observadores e participantes, as numerosas e recorrentes rebeliões urbanas do período pareciam indicar uma radicalização das camadas pobres dos guetos em direção à revolução armada negra. ${ }^{273}$

Contudo, nesse ponto, a posição de Carmichael e Hamilton em Black Power: The Politics of Liberation era, no mínimo, ambígua. Na obra, eles ainda vislumbravam uma outra solução possível - mesmo que bastante remota - para o cenário dramático que observavam. A despeito de alertarem para a possibilidade de um conflito racial iminente e manifestarem apoio à autodefesa dos afro-americanos, os autores a princípio recuavam diante de ações e propostas declarademente revolucionárias para o movimento Black Power. Ou seja, por mais que não desautorizassem o recurso à força em determinadas circunstâncias, Carmichael e Hamilton tampouco prescreviam abertamente o enfrentamento armado em seu programa político. Esta ambivalência manifestavase logo na epígrafe do livro onde os autores oferecem ao leitor o seu ultimato:

"Este livro apresenta uma ideologia e um framework político que representam a última oportunidade razoável para que esta sociedade resolva seus problemas raciais a fim de evitar uma longa e destrutiva guerra de guerrilhas. Que tal guerra violenta talvez seja inevitável não é aqui negado. Mas se houver a menor chance de evitá-la, a política do Black Power, conforme descrita neste livro, é vista como a única esperança viável". ${ }^{274}$

Se havia, como sugerem Carmichael e Hamilton, alguma esperança de evitar um conflito armado e revolucionário nos Estados Unidos, o quê, então, os autores propunham para o Movimento Black Power?

\footnotetext{
${ }^{273}$ GERSTLE, Gary. op. cit., p. 301.

274 "This book presents a political framework and ideology which represents the last reasonable opportunity for this society to work out its racial problems short of prolonged destructive guerrilla warfare. That such violent warfare may be unavoidable is not herein denied. But if there is the slightest chance to avoid it, the politics of Black Power as described in this book is seen as the only viable hope". CARMICHAEL, Stokely; HAMILTON, Charles V. op. cit., n.p.
} 


\subsection{Libertar a consciência e o gueto: a agenda político-identitária de Stokely Carmichael no livro Black Power}

"[O Black Power] É um chamado para os negros neste país se unirem, reconhecerem suas heranças, construírem um senso de comunidade. É um chamado para os negros começarem a definir seus próprios objetivos, liderar suas próprias organizações e apoiar essas organizações". ${ }^{275}$

Como vimos, Stokely Carmichael e Charles V. Hamilton colocavam em xeque os valores, interpretações, objetivos e estratégias - o modus operandi - que até então haviam pautado a atuação das lideranças do Movimento pelos Direitos Civis nos Estados Unidos. Isso significava que, para a militância radical do Movimento Black Power, não mais bastava "redimir" a nação e buscar a integração formal do negro na comunidade nacional norte-americana através de protestos não-violentos, do emprego da ação direta e de alianças com setores liberais e sindicais que orbitavam o Partido Democrata. Não era mais suficiente lograr o acesso ainda muito restrito de alguns poucos negros a partidos políticos existentes, cargos públicos, agências governamentais, programas de assistência social, campanhas eleitorais e demais instituições sociais. Era hora de operar transformações fundamentais nos padrões culturais e instituções racistas que sujeitavam os negros ao "colonialismo interno" norte-americano.

Assim, defendendo a justiça social e a emancipação subjetiva do "colonialismo", os autores e a militância do movimento ocupavam-se não da garantia de direitos civis básicos aos negros, mas sobretudo da busca por poder ou, em uma linguagem atual, por "empoderamento" de grupo - tanto psicológico quanto político. Projetando uma identidade negra nacional como ponto de partida de sua resistência antirracista, os proponentes do movimento Black Power concebiam a luta negra por dignidade em dois fronts complementares: cultural/identitário e político. Juntas, estas pautas tinham o duplo objetivo final, como expresso pelo historiador Gary Gerstle, de libertar a consciência e as comunidades afro-americanas da opressão racista. ${ }^{276}$

Em primeiro lugar, Carmichael e Hamilton propunham a autodefinição identitária - isto é,

\footnotetext{
275 "It is a call for black people in this country to unite, to recognize their heritage, to build a sense of community. It is a call for black people to begin to define their own goals, to lead their own organizations and to support those organizations". CARMICHAEL, Stokely; HAMILTON, Charles V. op. cit., p. 44.

${ }^{276}$ OMI, Michael; WINANT, Howard. op. cit., p. 170-171; VAN DEBURG, William L. op. cit., p. 24; GERSTLE, Gary, p. 295; CARMICHAEL, Stokely; THELWELL, Ekwueme M. Ready for the Revolution: The Life and Struggles of Stokely Carmichael (Kwame Ture). New York: Scribner, 2003, p. 548.
} 
a construção de uma "consciência negra" baseada no orgulho racial e na valorização das heranças (as "raízes") negras, suas manifestações culturais, históricas e estéticas distintivas - como ponto de partida para a solidariedade e ação políticas entre os afro-americanos. Convocando os negros a "redefinirem os termos" das relações que estabeleciam entre si e em relação à sociedade mais ampla, os autores buscavam construir uma identidade cultural negra positiva, livre das caracterizações deletérias impostas por séculos de opressão. Isso constituía, para eles, “[...] a primeira necessidade de um povo livre e o primeiro direito que qualquer opressor precisa suspender". 277

"Nosso objetivo é definir e encorajar uma nova consciência entre os negros, o que nos possibilitará avançar em direção a essas respostas e soluções [que procuramos]. Essa consciência pode [...] ser chamada de um sentido de povo [peoplehood]: orgulho, ao invés de vergonha, em relação à negritude [blackness] e uma atitude de responsabilidade fraternal entre todos os negros". 278

Segundo as perspectivas nacionalistas negras dos autores, esse processo de identificação individual e coletiva implicava que os negros nos Estados Unidos se reconhecessem primeiro como parte de um mesmo povo negro (black people), uma "nação" identitária e culturalmente distinta da sociedade branca mais ampla, e não simplesmente como "norte-americanos" (americans). ${ }^{279}$ Em outras palavras, a identidade que propunham Carmichael e Hamilton era nacional, racial e insurgente. Ela encarnava o projeto político-identitário particular do Movimento Black Power: por um lado, rebelava-se, como discutimos, contra a narrativa nacional excludente da "América Branca" (i.e., WASP) que historicamente priva(va) os negros do pleno acesso à

\footnotetext{
${ }^{277} \mathrm{Na}$ íntegra: "From now on we shall view ourselves as African-Americans and as black people who are in fact energetic, determined, intelligent, beautiful and peace loving". CARMICHAEL, Stokely; HAMILTON, Charles V. op. cit., p. 38 e "We shall have to struggle for the right to create our own terms through which to define ourselves and our relationship to the society, and to have these terms recognized. This is the first necessity of a free people, and the first right that any oppressor must suspend". Ibidem, p. 35; VAN DEBURG, William L. op. cit., p. 60.

278 "In addition, we aim to define and encourage a new consciousness among black people which will make it possible for us to proceed toward those answers and those solutions. This consciousness [...] might be called a sense of peoplehood: pride, rather than shame, in blackness, and an attitude of brotherly, communal responsibility among all black people". CARMICHAEL, Stokely; HAMILTON, Charles V. op. cit., p. XVI.

${ }^{279}$ Sobre o conceito de identificação em Stuart Hall, cf. HALL, Stuart. A identidade cultural na pósmodernidade. Rio de Janeiro: Lamparina, 2015, p. 11; Idem. Quem precisa da identidade? In: SILVA, Tomaz Tadeu (org. e trad.). Identidade e diferença: a perspectiva dos Estudos Culturais. Petrópolis: Vozes, 2000. p. 105-108.
} 
comunidade norte-americana; por outro, conforme expresso por Stokely Carmichael em um discurso anterior, buscava construir, nos Estados Unidos, uma comunidade de sentido e de pertencimento própria aos negros.

"Este país tem sido capaz de nos fazer sentir vergonha de sermos negros. Uma das primeiras conclusões de um povo livre é que devemos nos unir como um povo; devemos entender o conceito de povo [peoplehood] e não nos envergonharmos de nós mesmos. Temos que parar de imitar a sociedade branca, começar a criar para nós mesmos e para os nossos e começar a incorporar nossos próprios padrões culturais para nos agarrarmos às coisas que criamos - e darmos valor a elas". ${ }^{280}$

À época os autores julgavam que esse processo já estava em andamento na busca da comunidade afro-americana por uma "autoimagem" positiva e assertiva evidenciada pelo emprego cada vez mais recorrente dos termos African-American, Afro-American ou black no lugar da palavra em inglês Negro - expressão que, nos Estados Unidos, fora historicamente atribuída pelos brancos aos negros de maneira derrogatória e aviltante. ${ }^{281}$ Segundo eles, a desconstrução desses estereótipos racistas abririam caminho tanto para a coesão e o "sentimento de coletividade" (togetherness) almejados quanto para a autoaceitação individual; isto é, para o apreço do negro pelos seus próprios traços físicos, pelas marcas simbólicas ${ }^{282}$ que o racismo mobiliza(va) com fins de hierarquizar socialmente os grupos: a cor da pele, a textura do cabelo, o formato do nariz, etc.

Ao cabo deste processo de autodefinição e autoafirmação, a consciência e identidade negras surgiriam como um produto saudável "a serviço da libertação física e mental" da opressão racial. Somente então, vislumbravam os autores, a população negra se libertaria dos padrões e normas culturais a ela imposta pelos brancos, valorizaria a própria cultura e abraçaria o lema do Black Power de que "o negro é lindo" (“black is beautiful”): "a partir de agora, nós nos veremos como afro-americanos e como um povo negro que é de fato enérgico, determinado, inteligente,

\footnotetext{
280 "This country has been able to make us ashamed of being black. One of the first recognitions of a free people is that we must be united as a people; we must understand the concept of peoplehood and not be ashamed of ourselves. We must stop imitating white society and begin to create for ourselves and our own and begin to embody our own cultural patterns so that we will be holding to those things that we have created, and holding them dear". CARMICHAEL, Stokely. At Morgan State. In: From Black Power to Pan-Africanism. 2. ed. Lawrence Hill Books, 2007, p. 63.

${ }^{281}$ Uma tradução aproximada da palavra em inglês negro para o português seria o termo "preto" quando, no contexto brasileiro, é empregado em um sentido racista de desqualificação dos negros pelos brancos.

${ }^{282}$ HALL, Stuart. op cit., 2015, p. 37.
} 
belo e pacífico". 283

Uma vez assegurada a "integridade" da cultura e identidade negras, o Black Power partia, então, à solidariedade e ação mais propriamente "políticas". A esse respeito, em seu programa, os autores recorriam à proposição da autodeterminação negra, isto é, ao "poder de grupo" que garantisse à população afro-americana força política e autonomia de decisão em relação aos demais setores da sociedade. Com isso, Carmichael e Hamilton reforçavam o prognóstico radical do movimento de que a eliminação do racismo e da exploração econômica nos Estados Unidos somente seria possível através da redistribuição de recursos e de poder em benefício dos negros e das demais minorias sociais excluídas no país - hispânicos, indígenas, asiáticos, etc. Sob essa ótica, o Black Power tratava-se, portanto, de um projeto político abrangente que ambicionava reconstruir a sociedade norte-americana como um todo; não somente reorientar os valores nacionais, mas também buscar novas instituições sociais a partir das quais conceber um "sistema" político inteiramente novo:

"Este país não pode começar a resolver os problemas dos guetos enquanto continuar a depender de estruturas e instituições ultrapassadas. Um sistema de partidos políticos que procure apenas gerir conflitos e torcer pelo melhor não será capaz de servir um crescente corpo de negros excluídos. Um sistema educacional que, ano após ano, continua a aleijar centenas de milhares de crianças negras deve ser substituído por mecanismos totalmente novos de controle e gestão. Devemos começar a pensar e operar com base em formas de expressão inteiramente novas e substancialmente diferentes". ${ }^{284}$

Diante da amplitude das transformações pretendidas, Carmichael e Hamilton, no entanto, surpreenderam pela moderação das propostas concretas que apresentaram à militância negra. Curiosamente, no livro Black Power, o projeto político dos autores assentava-se sobre um descompasso aparente: diferentemente do diagnóstico nacionalista negro radical lançado contra o

283 "From now on we shall view ourselves as African-Americans and as black people who are in fact energetic, determined, intelligent, beautiful and peace-loving”. CARMICHAEL, Stokely; HAMILTON, Charles V. op cit., p. 38.

284 "This country cannot begin to solve the problems of the ghettos as long as it continues to hang on to outmoded structures and institutions. A political party system that seeks only to "manage conflict" and hope for the best will not be able to serve a growing body of alienated black people. An educational system which, year after year, continues to cripple hundreds of thousands of black children must be replaced by wholly new mechanisms of control and management. We must begin to operate in terms of new and substantially different forms of expression". CARMICHAEL, Stokely; HAMILTON, Charles V. op. cit., p. 164-165. 
"racismo institucional", a nação norte-americana e as práticas liberais do movimento negro, as ações que os autores propunham não rompiam plenamente com as aspirações reformistas da maioria dos afro-americanos. ${ }^{285}$ Ao contrário, como sugerimos anteriormente, Carmichael e Hamilton contemplavam, ainda, a possibilidade de operar uma profunda reestruturação social que evitasse uma saída revolucionária para o status quo vigente.

Na obra, a sobrevivência de vínculos reformistas evidenciava-se, sobretudo, na orientação política pluralista de "representatividade" e "controle comunitário" defendida pelo programa dos autores. Informados por experiências anteriores que marcaram suas trajetórias de ativismo junto ao SNCC, eles viam a luta do LCFO - Lowndes County Freedom Organization no Alabama como modelo para uma agenda política negra independente, popular e comunitária para o Movimento Black Power. Recuperando princípios da democracia participativa caros ao SNCC, Carmichael e Hamilton defendiam que os afro-americanos formassem seus próprios partidos e organizações (como o LCFO) para "tomar o controle" da vida social, política e econômica de suas comunidades e guetos das mãos dos brancos. Em linhas gerais, isto poderia se traduzir tanto em "libertar" os serviços e as instituições públicas já existentes - o comércio, a polícia, os conselhos escolares, as comissões de planejamento urbano, dentre outros - de toda ingerência “externa" e orientá-las segundo as demandas coletivas da comunidade negra quanto substituí-las por completo. O ponto central, contudo, era que os negros pobres liderassem suas próprias organizações e participassem, efetiva e não mais simbolicamente, dos processos decisórios que afetavam o dia-a-dia de suas comunidades. ${ }^{286}$

"[O] Black Power significa, por exemplo, que em Lowndes County, Alabama, um xerife negro pode pôr fim à brutalidade policial; que um assessor, um fiscal da receita e a secretaria de planejamento podem estipular, coletar e canalizar impostos para a construção de escolas e estradas melhores para a população negra. Em áreas onde, como Lowndes, os negros são maioria, eles tentarão usar seu poder para exercer o controle. É isto que buscam: controle. Quando em posição de minoria, Black Power significa representação adequada e partilha do controle. Significa a criação de bases de poder, de força, e não de fraqueza, pelas quais os negros possam exercer pressão para mudar padrões locais ou

${ }^{285}$ Esta contradição nas proposições dos autores é ressaltado na análise de OMI, Michael; WINANT, Howard. op. cit., p. 182. Cf. nota 18.

${ }^{286}$ Segue trecho na íntegra: "The point is obvious: black people must lead and run their own organizations. Only black people can convey the revolutionary idea - and it is a revolutionary idea - that black people can do things for themselves”. CARMICHAEL, Stokely; HAMILTON, Charles V. op. cit., p. 46. 
nacionais de opressão". ${ }^{287}$

Em termos práticos, as ações pretendidas pelos autores sob a rubrica de "controle comunitário" buscavam poder político e autonomia de decisão para muitos negros que, não raro, viam-se subrepresentados e até mesmo excluídos de setores essenciais da vida urbana como educação, moradia e comércio. No sistema educacional, por exemplo, Carmichael e Hamilton convocavam os residentes negros a assumir para si a tarefa de administrar coletivamente as escolas e secretarias de educação que atendiam seus filhos, colocando-as a serviço dos valores e interesses da comunidade local. Para eles, "os pais negros devem buscar como meta o controle efetivo das escolas públicas de sua comunidade: contratação e demissão de professores, seleção de material didático, determinação de padrões de avaliação, etc". ${ }^{288}$ Dessa forma, os proponentes do Black Power reforçavam que uma educação de qualidade no gueto não somente prescindia da presença de alunos, professores e diretores brancos (em outras palavras, prescindia da integração dos negros a instituições majoritariamente brancas) como deveria ser construída coletivamente através do engajamento da comunidade negra.

Atentando ao problema da especulação imobiliária, da superlotação e precarização das moradias nos guetos, Carmichael e Hamilton propunham que locatários negros se juntassem em organizações a fim de combater o descaso dos proprietários - estes, não raro recusavam-se a prestar cuidados mínimos nos imovéis alugados como reparos hidráulicos, elétricos, controle de pragas - e a cobrança de aluguéis abusivos. Organizados em grande número, os moradores poderiam lançar boicotes ao pagamento de alugueis para pressionar o poder público a intervir e os proprietários a aceitarem suas demandas. Em última instância, os inquilinos estariam até no direito de requerer o confisco dos imóveis de proprietáros recalcitrantes junto ao Estado para serem revertidos à administração coletiva de organizações no gueto:

"O proprietário negligente está perpetuando uma condição socialmente perniciosa e ele não pode se esconder atrás da rubrica do direito à

287 "Black Power means, for example, that in Lowndes County, Alabama, a black sheriff can end police brutality. A black tax assessor and tax collector and county board of revenue can lay, collect and channel tax monies for the building of better roads and schools serving black people. In such areas as Lowndes, where black people have a majority, they will attempt to use power to exercise control. This is what they seek: control. When black people lack a majority, Black Power means proper representation and sharing of control. It means the creation of power bases, of strength, from which black people can press to change local or nation-wide patterns of oppression - instead of from weakness". Ibidem, p. 46.

${ }^{288}$ Ibidem, p. 167. 
propriedade. A comunidade negra deve insistir que os direitos humanos tenham precedência sobre os direitos de propriedade e sustentar esta insistência de maneira que seja do interesse da sociedade branca agir moralmente". 289

De maneira similar, empresas, comerciantes e instituições financeiras externas instaladas no gueto também deveriam ser pressionados a desempenhar um papel social junto aos seus consumidores. Opondo-se à canalização de recursos para fora de suas comunidades, os autores entendiam que, uma vez organizados, os consumidores afro-americanos poderiam exigir que a iniciativa privada reinvestisse boa parte dos seus lucros no próprio gueto. Tais "contrapartidas" poderiam ocorrer pela oferta de mais empregos aos negros, o financiamento de organizações comunitárias, a distribuição de bolsas de estudos, dentre outras. Ou seja, aconselham eles, "se um comerciante quiser clientes dentro da comunidade negra, ele precisa ser forçado a entender que deve contribuir para esta mesma comunidade". 290

Por fim, conforme vimos, Stokely Carmichael e Charles V. Hamilton entendiam o Black Power como um amplo movimento identitário e político voltado à libertação dos negros das amarras subjetivas e institucionais impostas pelo racismo nos Estados Unidos. No cerne da luta contra a supremacia branca que propunham, desenvolvia-se tanto uma disputa pelo controle das instituições - pela "representatividade" e acesso ao "poder" político - quanto um choque entre identidades "nacionais" distintas, uma norte-americana (branca) e a outra negra. À medida que o Black Power ganhava adeptos e influenciava setores da Nova Esquerda para além da comunidade negra, os efeitos deste "deslocamento", desta "fragmentação" das identidades coletivas desencadearam um processo avassalador no seio da comunidade nacional norte-americana. Confrontada pela rebelião contra o "americanismo" - i.e., o sistema de valores e instituições nacionais - capitaneada pelos proponentes do Black Power, a unanimidade em torno da América WASP haveria de cair por terra. ${ }^{291}$

289 Nesta passagem nota-se novamente o "tom" anticapitalista dos autores que mencionamos anteriormente. No original: "The absentee slumlord is perpetuating a socially detrimental condition, and he should not be allowed to hide behind the rubric of property rights. The black community must insist that the goal of human rights take precedent over property rights, and back up that insistence in ways which will make it in the self-interest of the white society to act morally". Ibidem, p. 172.

${ }^{290}$ Ibidem, p. 173.

${ }^{291}$ VAN DEBURG, William L. op. cit., p. 61; GERSTLE, Gary. op. cit., p. 327-329 e OMI, Michael; WINANT, Howard. op. cit., p. 162-163. 


\subsection{A repercussão do livro}

Lançado em outubro de 1967, Black Power: The Politics of Liberation atingiu um público leitor bastante amplo e diversificado. Considerada um best-seller por alguns, a obra contou com tiragens e vendas expressivas a um preço popular - a primeira edição custava entre U\$1,95 e U\$4,95 a depender do material empregado, papel ou capa dura - além de traduções para o espanhol e outros idiomas. Nos Estados Unidos, segundo estimativas de Charles V. Hamilton, durante um ano e meio após a sua publicação, o livro teria vendido por volta de 5,000 exemplares semanais. Assim, dada a circulação do impresso e o interesse público que cercava o movimento Black Power na segunda metade da década, a obra foi concebida tendo em vista um público leitor mais amplo para além do movimento negro. Isto é, por meio dela, os autores buscavam, também, estabelecer um diálogo com o leitor norte-americano branco. ${ }^{292}$

Com o tempo, o livro notabilizou-se no meio acadêmico e em nichos intelectuais mais restritos. Juntamente às obras Where do We Go From Here: Chaos or Community? e The Crisis of the Negro Intellectual: A Historical Analysis of the Failure of Black Leadership - lançadas no mesmo ano por Martin Luther King e pelo intelectual nacionalista negro Harold Cruse, respectivamente - o texto de Carmichael e Hamilton se consolidou como uma importante referência para a compreensão do pensamento político e social negro da década de 1960. Nas décadas seguintes à sua publicação, tornou-se leitura frequentemente requisitada, por exemplo, em cursos de Ciência Política e Sociologia (nos níveis de graduação e pós) e em departamentos de Black Studies, African-American Studies, Africana Studies, dentre outros, surgidos nas universidades norte-americanas a partir das manifestações estudantis negras do Movimento Black Power. $^{293}$

Contudo, o livro também foi alvo de importantes questionamentos. Em particular, a recepção ao programa de Carmichael e Hamilton não foi de toda favorável entre parte expressiva da academia e da crítica especializada. De maneira geral, diversos comentaristas brancos e negros

292 GREENE II, Robert. "Black Power" and Stokely Carmichael's defining of ideology in 1967. Disponível em: $<$ https://s-usih.org/2013/11/black-power-and-stokely-carmichaels-defining-of-ideology-in1967\#_ftn2>. Acesso em: 31 de julho de 2018. Para os preços da primeira edição do livro, cf. POWLEDGE, Fred. A Slogan, a Chant, a Threat. The New York Times, 10 dez. 1967, p. 362.

${ }^{293}$ HAMILTON, Charles V.; HARRIS, Fredrick C. op. cit., p. 25; JOSEPH, Peniel E. Stokely: A Life. New York: Basic Civitas, 2014, p. 232; KING JR, Martin Luther. Where do We Go from Here: chaos or community? Boston: Beacon Press, 1967 e CRUSE, Harold. The Crisis of the Negro Intellectual: a Historical Analysis of the Failure of Black Leadership. New York: New York Review Books, 2005. 
do período revelaram sua surpresa e até sua "decepção" (como fizera o intelectual Christopher Lasch em extensa resenha para o The New York Review of Books) com a timidez e a moderação das ações concretas apresentadas na obra para solucionar o problema do racismo no país. Em maior ou menor grau, esses intelectuais faziam coro à avaliação de Fred Powledge, jornalista do The New York Times e autor de livros sobre os Direitos Civis e Black Power, para quem "as conclusões [de Carmichael e Hamilton] sobre o que deve ser feito são incrivelmente breves e surpreendentemente não-revolucionárias". No mesmo tom de Powledge, Robert L. Allen, sociólogo, ativista negro e professor da San Jose State University, um epicentro das mobilizações universitárias do movimento Black Power na Califórnia, considerava que a obra constituía "em grande parte um ensaio sobre reformismo liberal". 294

Outros intelectuais mostraram-se ainda mais incisivos em suas divergências. Ralph H. Turner, sociólogo da University of California and Los Angeles e especialista referência no campo de estudos dos novos movimentos sociais, por exemplo, classificou o Black Power proposto pelos autores como um "símbolo à procura de um movimento"; isto é, um grito de indignação da militância negra ainda desprovido de "um programa aceitável" que servisse como horizonte para o movimento. ${ }^{295}$ De maneira similar, Michael R. Winston, historiador negro contemporâneo de Carmichael na Howard University e futuro professor da instituição, teceu duras críticas aos autores de Black Power. Para ele, Carmichael e Hamilton traçavam uma crítica demolidora dos integracionistas, isto é, escreviam um "réquiem dos Direitos Civis e uma penetrante denúncia do racismo", mas limitavam-se a isso. Segundo argumentava, os autores haviam falhado em desenvolver alternativas concretas para o Black Power, restringindo-se a "soluções" inconsistentes com os referenciais teóricos radicais que mobilizavam em seu diagnóstico das relações raciais:

"Uma ironia é que os autores, apesar de todo o discurso sobre o 'Terceiro Mundo', não são intelectuais revolucionários de forma alguma, mas essencialmente norte-americanos em sua abordagem ad hoc e fundamentalmente reformista da ação política; em sua crença de que mais

${ }^{294}$ LASCH, Christopher. A Special Supplement: The Trouble with Black Power. The New York Review of Books, 29 fev. 1968. Disponível em: <https://www.nybooks.com/articles/1968/02/29/a-specialsupplement-the-trouble-with-black-power/>. Acesso em: 08 de agosto de 2017; POWLEDGE, Fred. A Slogan, a Chant, a Threat. The New York Times, 10 dez. 1967, p. 362; ALLEN, Robert L. Black Awakening in Capitalist America: an Analytic History apud OMI, Michael; WINANT, Howard. op. cit., p. 182 (nota 18).

${ }^{295}$ TURNER, Ralph H. Review. American Journal of Sociology, v. 74, n. 2, set. 1968, p. 197-199. 
poder político negro se traduzirá em mudança social progressiva; e em seu otimismo em relação à regeneração da comunidade [negra] e à possibilidade de criar uma ordem social humana nos Estados Unidos". 296

De fato, conforme notado à época por alguns comentaristas, o projeto político-identitário de Stokely Carmichael e Charles V. Hamilton elaborado em Black Power: The Politics of Liberation era atravessado por um paradoxo central. De um lado, como já indicamos anteriormente, provava-se radical, pois reivindicava a necessidade de operar mudanças fundamentais nas instituições, na cultura e valores nacionais do país a partir do ponto de vista da militância negra; mas de outro, evidenciava uma hesitação em romper com todos os vínculos com o reformismo que havia caracterizado a atuação anterior dos seus autores. Décadas depois, no posfácio acrescentado à edição de 1992 da obra, Carmichael, àquela altura um revolucionário pan-africanista veterano, reconheceria a permanência desses vínculos nos seguintes termos: “ $\mathrm{O}$ livro não advoga a revolução. Ele prega a reforma. Ele enuncia sua posição anticapitalista com uma visão de uma sociedade livre de exploração. Todas as ações propostas neste livro são totalmente legais". 297

Vale lembrar que, à época em que escreviam Carmichael e Hamilton, não era incomum que grupos e ativistas do Movimento Black Power acomodassem com certa fluidez pautas nacionalistas negras e pluralistas à primeira vista contraditórias. Em diversas situações, como discutimos na abertura do capítulo, estas preocupações coexistiam nas perspectivas dos militantes radicais. Para muitos deles, e certamente para os nossos autores, a recusa à "América Branca” e o clamor pela libertação plena da opressão racista a princípio não impediam que alimentassem alguma - mesmo que bastante tênue como provado pela epígrafe da obra - esperança de encontrar um lugar digno para os negros nos Estados Unidos. Dessa forma, é possível que, conscientes do fato de que os afro-americanos constituíam minoria populacional nos Estados Unidos, os autores refreassem o seu radicalismo com um certo pragmatismo programático.

\footnotetext{
296 "One irony is that the authors, for all their talk of the 'Third World', are not basically revolutionary intellectuals at all, but American to the core in their fundamentally ad hoc, reformist approach to political action, their belief that more Negro political power will mean progressive social change and their optimism about community regeneration and the possibility of creating a humane social order in the United States". WINSTON, Michael R. Review: Black Power, White Power, and the Negro Intellectual. The Journal of Negro Education, v. 38, n. 2, spring 1969, p. 162-163.

297 "The book does not advocate revolution. It preaches reform. It states its anticapitalist position and solution with a vision of a society free from exploitation. All action proposed in the book is totally legal". CARMICHAEL, Stokely; HAMILTON, Charles V. op cit., p. 188.
} 
No entanto, sobretudo para Stokely Carmichael, essa ambiguidade duraria muito pouco e logo daria espaço a uma agenda político-identitária abertamente revolucionária e transnacional. Àquela altura, entre 1966 e 1967, as perspectivas do ativista passavam por reformulações constantes informadas pelo sentimento de urgência oriundo do acirramento das tensões raciais que cindiam o país, mas também por eventos e experiências impactantes no chamado "Terceiro Mundo". Aproximando, como vimos no livro Black Power, a luta negra nos Estados Unidos aos processos de libertação nacional na África, Ásia e América Latina; Stokely voltava sua atenção cada vez mais aos principais palcos, dilemas e encruzilhadas políticas transnacionais que galvanizavam as lutas dos "condenados da terra" por autodeterminação em meio à Guerra Fria. 


\section{CAPÍTULO 4 - A conformação de uma política e identidade negras transnacionais nos discursos e artigos de Stokely Carmichael (1967-1971)}

No capítulo anterior, vimos que o projeto político-identitário de Stokely Carmichael para o Movimento Black Power calcava-se sobre uma leitura radical e nacionalista negra das relações raciais nos Estados Unidos. No centro das preocupações e denúncias dos autores de Black Power: The Politics of Liberation figurava a análise do racismo como um fenômeno estruturante das instituições, dos valores e da identidade norte-americana que precisava ser urgentemente eliminado para dar lugar a uma comunidade nacional minimamente "viável" aos afro-americanos. Voltando-se à resolução dos dilemas colocados pela opressão racial, Stokely Carmichael e Charles V. Hamilton concebiam a construção de uma vigorosa identidade negra no país e a tomada do controle político (a autodeterminação) dos guetos afro-americanos como caminhos incontornáveis à destruição do "colonialismo interno" que os afligia.

Neste capítulo, discutiremos como a agenda político-identitária formulada por Stokely Carmichael na obra Black Power passou por importantes reconfigurações quando, sobretudo a partir de 1967, o ativista vinculou-se às disputas e arenas políticas da Guerra Fria que orientavam as lutas por autodeterminação e soberania nacional das antigas colônias europeias. Aproximandose, então, de lideranças anti-imperialistas e anticoloniais na América Latina, Ásia e África, Stokely deslocava o foco do seu projeto de luta antirracista do Black Power - até então marcadamente doméstico - para além das fronteiras nacionais norte-americanas, engrossando o coro do levante terceiro-mundista em vigor no período. Essa inflexão do ativista, documentada de maneira fragmentada e dispersa em seus discursos e artigos de finais da década de 1960, traduzia sua gradual "reinvenção" política em um intelectual revolucionário cuja crescente projeção internacional combinava-se - e eventualmente substituiria - o lugar de destaque por ele ocupado à frente do movimento negro norte-americano.

Portanto, àquela altura, conforme observaremos nessa documentação posteriormente reunida em Stokely Speaks: From Black Power to Pan-Africanism (1971), o diagnóstico e o programa de Carmichael adquiriam amplitude e enfâse renovadas: para ele, cada vez mais, os problemas do racismo dentro e fora dos Estados Unidos vinculavam-se às dinâmicas globais de dominação que ultrapassavam o recorte predominantemente nacional - a citada "América Branca" - privilegiado no livro Black Power: The politics of Liberation. Isto é, em seus artigos e 
discursos de finais da década, Carmichael identificava o racismo como fenômeno ocidental mais amplo, aliado às relações capitalistas de dominação do "Ocidente Branco" - capitaneado, à época, pelos imperialistas norte-americanos, mas que envolvia, também, os colonizadores europeus - com os "povos de cor" (peoples of color) do Terceiro Mundo. Cada vez mais integrado a um projeto político revolucionário anticolonial, anti-imperialista e anticapitalista, o programa de Carmichael para o movimento Black Power transmutava-se, aos poucos, em uma agenda política-identitária necessariamente transnacional: o pan-africanismo.

Dessa forma, em um primeiro momento, situaremos o contexto mais amplo da Guerra Fria dentro do qual as perspectivas de Stokely Carmichael para o Black Power ganhavam novos matizes. Em seguida, acompanharemos essas reconfigurações no projeto político do ativista iniciando pela sua resistência ao envolvimento norte-americano na Guerra do Vietnã, importante ponto de entrada na agenda terceiro-mundista e revolucionária do período, que impulsionou Stokely a percorrer um longo tour internacional no segundo semestre de 1967. Passando por Londres, Havana, Hanoi, Argel, Conacri, dentre outros lugares, o ativista estabeleceu solidariedades políticas transnacionais, buscando diálogos entre o Black Power e os distintos projetos radicais no Terceiro Mundo. Por último, veremos que Carmichael, à semelhança do que ocorrera com Malcolm X alguns anos antes, retirou das sociabilidades intelectuais e políticas firmadas em suas viagens uma forte convicção na direção revolucionária e no alcance Atlântico assumido pela luta antirracista. Sob a influência de Kwame Nkrumah, líder pan-africanista de Gana, Carmichael passava a enxergar, então, diáspora e continente como partes indissociáveis da luta negra por autodeterminação, unificação política e econômica da África sob um mesmo governo socialista.

\subsection{Terceiro-mundismo, Guerra Fria e a agenda transnacional de Stokely Carmichael para o movimento Black Power}

"Não se trata apenas de uma luta para mudar sistemas. É uma luta pela nossa própria humanidade, nossa liberdade de viver, de termos o tipo de cultura e linguagem que desejarmos e de vivermos, funcionarmos e desfrutarmos da riqueza da Terra. Da mesma forma que os vietnamitas estão lutando pela humanidade, o mundo árabe está lutando pela humanidade, nossas forças na África estão lutando pela humanidade e os latino-americanos estão lutando pela humanidade, o negro na América também está lutando pela 
humanidade. Nós estamos ao lado do Terceiro Mundo". ${ }^{298}$

Ao mesmo tempo que sistematizava, entre finais de 1966 e no decorrer de 1967, o seu projeto político para o movimento Black Power nos Estados Unidos, Stokely Carmichael e a militância negra radical também se abriam a caminhos e pautas políticas que transcendiam o escopo do movimento afro-americano no país. O interesse crescente do militante pelas lutas anticoloniais, revoluções e levantes independentistas em países africanos, asiáticos e latinoamericanos informavam, gradualmente, uma reinvenção em sua posição de intelectual público, sua orientação política e visão de mundo. "Símbolo inquestionável dos radicais negros na América", destaca seu biógrafo, "Carmichael voltou sua atenção à arriscada proposta de fazer a transição para um revolucionário internacional". ${ }^{299}$ Dividindo-se entre as obrigações que o lugar de porta-voz do movimento Black Power lhe impunham nos Estados Unidos e a curiosidade por explorar novas arenas políticas internacionais, Stokely abandora em definitivo os resquícios do reformismo característicos de sua atuação no SNCC na primeira metade da década - a ação direta e a democracia participativa, por exemplo - em favor de uma agenda abertamente revolucionária que combinava a luta antirracista às pautas anti-imperialistas e anticapitalistas que mobilizavam as esquerdas nas "periferias" do sistema capitalista mundial.

Nessa inflexão, é importante notarmos, Carmichael certamente não esteve sozinho. Pelo contrário, na segunda metade dos anos 1960, as transformações vivenciadas pelo ativista inscreviam-se em um amplo quadro de reconfiguração das esquerdas - norte-americanas e internacionais - desencadeado pela revisão da ortodoxia marxista cristalizada no modelo soviético. Naquele contexto, em meio ao processo de autocrítica inaugurado no seio do campo comunista internacional após as denúncias, em 1956, de Nikita Kruschev acerca dos crimes, dos expurgos e das gulags na União Soviética de Josef Stálin (1927-1953), novas leituras marxistas surgiam vinculadas às disputas geopolíticas introduzidas pela Guerra Fria. ${ }^{300}$

\footnotetext{
298 "It is not just a fight to change systems it is a fight for our very humanity, our freedom to live, to have the type of culture and language we desire, and to live and function and enjoy the wealth of the Earth. Just as the Vietnamese are fighting for humanity, just as the Arab world is fighting for humanity, just as our forces in Africa are fighting for humanity, just as Latin Americans are fighting for humanity, the black man in America is fighting for humanity. We stand with the Third World". CARMICHAEL, Stokely. The Black American and Palestinian Revolutions. In: Stokely Speaks: From Black Power to Pan-Africanism. 2a. ed. Lawrence Hill Books, 2007, p. 142-143.

${ }^{299}$ JOSEPH, Peniel E. Stokely: a life. New York: Basic Civitas, 2014, p. 173; 176.

300 Ao fim da Segunda Guerra Mundial, a vitória dos Aliados foi acompanhada de numerosas reconfigurações nas relações internacionais que escapam aos limites investigativos do nosso trabalho.
} 
A esse respeito, os processos de descolonização e as lutas anti-imperialistas surgidas entre os anos de 1950 e 1970 no então chamado Terceiro Mundo desempenharam um papel decisivo na adesão das esquerdas a novas perspectivas revolucionárias vigentes mundo afora - nos Estados Unidos, cabe frisarmos, essa ruptura foi particularmente impactante dado o histórico reformista de organizações estudantis paradigmáticas para a geração de Carmichael como a SDS - Students for a Democratic Society e o SNCC. ${ }^{301}$ No calor dos movimentos de libertação afro-asiáticas e latino-americanas, muitos setores do campo progressista internacional propuseram-se a repensar o lugar de "sujeito histórico da revolução" ocupado pelo proletariado industrial dos países desenvolvidos na tradição marxista. Insufladas pelo levante de focos guerrilheiros e lutas campesinas no "Terceiro Mundo", as esquerdas revisitavam a primazia atribuída à classe trabalhadora industrial - leitura esta muito associada à chamada "Velha Esquerda" soviética dos anos 1930-1940 - em favor de uma via para o socialismo cujo protagonismo revolucionário recaía sobre os "povos não-brancos" em luta contra as forças colonialistas e imperialistas do capitalismo ocidental. $^{302}$

Nesse cenário, as relações oscilantes da URSS com os movimentos de libertação nacional também contribuíram para que as "novas esquerdas" que se radicalizavam simpatizassem com o drama dos "condenados da terra" e optassem por caminhos socialistas outros àqueles preconizados pelo Kremlin. Em particular, a política soviética de coexistência pacífica (détente)

Portanto, para um panorama introdutório acerca das disputas geopolíticas trazidas pela Guerra Fria, cf. MUNHOZ, Sidnei. Imperialismo e Anti-imperialismo, Comunismo e Anticomunismo durante a Guerra Fria. Florianópolis: Revista Esboços, v. 23, n. 36, fev. 2017, p. 452-469. Sobre a reconfiguração das esquerdas, cf. ELBAUM, Max. Revolution in the air. Sixties radicals turn to Lenin, Mao and Che. $2 \mathrm{a}$ ed. London \& New York: Verso, 2018, p. 41-58.

301 Cabe destacarmos aqui que a expressão "Terceiro Mundo" foi utilizada pela primeira vez pelo economista, demógrafo e sociólogo francês Alfred Sauvy em um pequeno texto de 1952 intitulado Trois mondes, un planéte escrito para o periódico L'Observateur. No texto, Sauvy convoca os países capitalistas do "Primeiro Mundo" a atentarem aos riscos à sua hegemonia global colocados pelas mazelas sociais, fome e o crescimento demográfico desordenado nos países subdesenvolvidos. Esta combinação explosiva, argumentava o autor, tornava os países pobres mais propensos ao socialismo do "Segundo Mundo" do que ao capitalismo. Segundo ele, caso negligenciasse esta situação, o Primeiro Mundo veria, à maneira do ocorrido com a nobreza e o clero durante a Revolução Francesa, que "depois de ter sido ignorado, explorado, desprezado como o Terceiro Estado, o Terceiro Mundo vai, também, ser alguma coisa". Lido como um indicador da radicalização das camadas populares e médias dos países subdesenvolvidos, o ultimato expresso pelo termo difundiu-se entre as esquerdas dos anos 1960 e 1970. Sobre o assunto, cf. GENEROSO, Lidia Maria de Abreu. "O povo colonizado não está sozinho": Terceiro Mundo, antiimperialismo e revolução nas páginas da revista Tricontinental (1967-1976). Dissertação de Mestrado Instituto de Ciências Humanas e Sociais. Universidade Federal de Ouro Preto: Mariana, 2018. p. 22-23.

${ }^{302}$ ELBAUM, Max. op. cit., p. 2-3; 47-51 e GENEROSO, Lidia Maria de Abreu. op. cit., p. 20-21. 
com Washington causava desconfiança entre parte significativa do espectro radical de finais da década de 1960 para o qual a vitória sobre a ordem capitalista passaria necessariamente pela luta armada. Acusada de "revisionismo" - isto é, de abrir mão dos princípios revolucionários do marxismo-leninismo - pela China maoísta, a URSS perdia influência para propostas mais combativas que apelavam ao sentimento de urgência dos militantes da época. ${ }^{303}$ Dessa maneira, voltando-se atentamente aos desdobramentos das Revoluções Chinesa (1949) e Cubana (1959), das guerras de independência na Argélia e no Vietnã, da questão árabe-israelense no Oriente Médio e da erupção de lutas populares nacionalistas e/ou marxistas armadas contra os decadentes impérios coloniais em África; as esquerdas radicais dos anos sessenta convenciam-se de que uma transformação iminente do mundo estava ao alcance da sua geração. ${ }^{304}$

À época, essa percepção reforçava-se, ainda, pela emergência, desde a Conferência de Bandung de 1955, do "Terceiro Mundo" como um "fato novo" no jogo de forças que caracterizava as relações internacionais durante a Guerra Fria. Na cidade de Bandung, Indonésia, pela primeira vez um conjunto de ex-colônias recém-independentes - ou em vias de tornarem-se independentes - articularam-se em eixos programáticos próprios, defendendo a autodeterminação e soberania nacionais dos povos afro-asiáticos em face das pressões e ingerências exercidas pelos blocos norte-americano e soviético. Reunindo líderes e chefes de Estado centrais à luta anticolonial do período, o encontro em Bandung marcou a importância de uma autoconsciência entre o espectro terceiro-mundista fundamentada na resistência compartilhada à dominação imperial e na cooperação mútua entre países oprimidos. Ao defender a era das descolonizações e inspirar lutas antirracistas mundo afora, Bandung inaugurou um poderoso movimento de autoafirmação e solidariedade política transnacional entre os povos afro-asiáticos cujas reverberações foram sentidas pelas diversas esquerdas dos anos sessenta, inclusive entre o movimento negro norte-americano. Naquele momento, o "espírito de Bandung” desdobrou-se em fóruns políticos

\footnotetext{
${ }^{303}$ Contrapondo-se à URSS, a China procurava se posicionar como "aliada natural" dos povos oprimidos, apresentando o que julgava ser a única alternativa "viável" tanto aos projetos de modernização capitalista quanto à coexistência pacífica adotada pelos soviéticos. Com isso, o Partido Comunista Chinês (PCC) buscava atrair as nações do Terceiro Mundo para a órbita maoísta que preconizava a luta armada a partir da organização do campesinato tido como força revolucionária por excelência. Rompendo com os soviéticos, o primeiro-ministro de Mao, Shu Enlai, buscou aproximação diplomática com países africanos - Argélia, Etiópia, Egito, Gana, Guiné, Mali, Marrocos, Somália e Sudão. Dessa forma, ao passo que, na década de 1950, a República Popular da China desempenhou um papel decisivo na defesa do regime de Kim Il Sung durante a Guerra da Coreia; nos anos 1960, o país buscava se afirmar como um dos principais aliados do Vietnã do Norte na luta contra os norte-americanos. Cf. MUNHOZ, Sidnei. op. cit., p. 463-465. ${ }^{304}$ ELBAUM, Max. op. cit., p. 53-54 e GENEROSO, Lidia Maria de Abreu. op. cit., p. 20.
} 
internacionais - em particular, na fundação do Movimento Não-Alinhado em Belgrado, 1961, e, sobretudo, na Conferência Tricontinental em Havana, 1966 - nos quais lideranças afro-asiáticas e latino-americanas firmavam pautas e sociabilidades terceiro-mundistas que alimentavam a luta de Stokely Carmichael e do Black Power contra a supremacia branca. ${ }^{305}$

Por essas razões, para Carmichael e tantos outros de sua geração radicalizados pelo Movimento Black Power e pela Guerra do Vietnã, o ambiente efervescente da Guerra Fria fortalecia o sentimento de que o mundo se convulsionava e que a "revolução estava no ar". Não por acaso, em finais da década de 1960 e início de 1970, um amplo front de radicalismo ganhava corpo nos Estados Unidos congregando movimentos de distintos perfis e orientações para os quais as turbulências domésticas e internacionais do período apresentavam-se de maneira interconectada. Ressignificando o cânone marxista à luz das experiências revolucionárias do período, esse amplo espectro radical - formado, grosso modo, por revolucionários e nacionalistas negros do Black Power, ativistas brancos antibelicistas (em sua maioria estudantes universitários) e pela juventude marginalizada dos movimentos hispano-americano, sino-americano, indígena, LGBT e feminista - conectava a política externa norte-americana no "Terceiro Mundo" ao racismo e à desigualdade econômica que estruturavam a vida social no interior do país. Caracterizando os Estados Unidos como uma potência imperial liderando a expropriação dos

\footnotetext{
${ }^{305}$ Em 1955, a Conferência de Bandung lançou as bases da inserção internacional dos países afro-asiáticos na Guerra Fria. Sediado pelo presidente indonésio Ahmed Sukarno, o encontro contou com a presença de importantes representantes do Terceiro Mundo dentre os quais destacam-se o primeiro-ministro da Índia Jawaharlal Nehru, o revolucionário vietnamita Ho Chi Minh, o premiê da República Popular da China Shu Enlai e o líder do nacionalismo árabe e presidente egípcio Gamal Abdel Nasser. Além desses, a Costa do Ouro (atual Gana) que, dois anos depois tornou-se independente com a liderança de Kwame Nkrumah, também esteve presente. Por sua vez, os afro-americanos foram representados por Adam Clayton Powell e Richard Wright, congressista e jornalista ali presentes na condição de observadores. Na ocasião, rejeitando o alinhamento ao binarismo entre os campos soviético e norte-americano, os países ali reunidos estabeleceram princípios de cooperação mútua com vistas à promoção da paz, à defesa da soberania dos signatários, ao respeito dos direitos humanos e à autonomia dos povos vítimas do colonialismo ocidental. Em outras palavras, buscavam mudar a "lei do mais forte", lógica que imperava nas relações internacionais desiguais que afligiam os povos de Bandung, para uma convivência internacional regulada pela diplomacia e pelo Direito Internacional expressos na Carta das Nações Unidas. Nos anos seguintes, as sociabilidades afro-asiátias firmadas na Conferência abriram caminho para o surgimento do Movimento Não-Alinhado, fundado em 1961 na cidade de Belgrado (Iugoslávia), e para o tricontinentalismo cubano discutido à frente neste capítulo - ao qual Stokely Carmichael se vinculou em sua visita à ilha em julho de 1967. Sobre a Conferência de Bandung, cf. BISSIO, Beatriz. A Guerra Fria vista a partir do Sul. Diálogos, v. 22, n. 01, jan./abr. 2018, p. 115-125 e FRASER, Cary. An American Dilemma: Race and Realpolitik in the American Response to the Bandung Conference, 1955. In: PLUMMER, Brenda Gayle (ed.). Window on Freedom: Race, Civil Rights and Foreign Affairs, 1945-1988. Chapel Hill and London: University of North Carolina Press, 2003. p. 115-140.
} 
povos "não-brancos" mundo afora, muitos radicais de final da década - dentre eles, como veremos, Stokely Carmichael - concluíram que o "sistema norte-americano" era ilegítimo e não deveria simplesmente ser reformado, mas sim completamente subvertido. ${ }^{306}$

No entanto, mesmo que boa parte das esquerdas do período convergissem em seu diagnóstico acerca das interconexões entre imperialismo, racismo e capitalismo, os caminhos concebidos para a superação desses "males" comportavam inúmeros matizes e diferenças. Frequentemente, radicais brancos da Nova Esquerda e militantes do movimento negro que se consideravam "marxistas", "maoístas", "marxistas-leninistas" e/ou "nacionalistas" que recorriam à tese do "colonialismo interno", viam-se às voltas quanto à ênfase, o escopo e a forma que a luta revolucionária deveria assumir. No caso de Stokely Carmichael, por exemplo, uma relação ambivalente com o marxismo se desenhava mediada pela ênfase que o ativista dedicava às dimensões raciais que tipificavam a opressão dos negros em detrimento de um recorte de classe alinhado à ortodoxia marxista. De toda forma, a despeito da desconfiança que Carmichael e alguns setores nacionalistas negros nutriam com o que por vezes alegavam serem "ideologias eurocêntricas", veremos que, no projeto político do ativista, perspectivas anticapitalistas e nacionalistas negras combinavam-se para conformar uma visão de mundo fortemente inspirada pela resistência "não-branca” à opressão na África, Ásia, América Latina e Oriente Médio. ${ }^{307}$

Em suma, inscrita no processo de reconfiguração das esquerdas dentro e fora dos Estados Unidos durante os anos sessenta, a agenda político-identitária de Stokely Carmichael para o movimento Black Power também se construía transnacionalmente. Isto é, para além das questões próprias ao movimento negro norte-americano, o projeto político antirracista do ativista vinculava-se às solidariedades anti-imperialistas, anticoloniais e anticapitalistas que faziam do Terceiro Mundo uma força revolucionária dentro da geopolítica da Guerra Fria.

Como veremos, os efeitos dessa clivagem nas perspectivas político-identitárias de Carmichael foram bastante significativos: de um lado, o ativista passava a situar o Black Power claramente dentro do campo revolucionário, considerando-o parte integrante das aspirações terceiro-mundistas que almejavam criar um "mundo novo" pela força das armas; de outro, ele ressignificava a identidade coletiva "nacional" do movimento ao aproximar os afro-americanos de uma comunidade transnacional mais ampla composta pelos "condenados da terra" -

\footnotetext{
${ }^{306}$ ELBAUM, Max. op. cit., p. 19; 27-33.

307 Ibidem, p. 41-42; 46.
} 
vietnamitas, cubanos, argelinos, palestinos, guineenses e tantos outros povos que à época clamavam por autodeterminação e soberania nacional. Os tortuosos caminhos e embates que levam à consolidação dessas pautas terceiro-mundistas no pensamento e na prática militante de Stokely Carmichael serão discutidos nas seções a seguir.

\subsection{1. "Hell no, we won't go!": Guerra do Vietnã, movimento antibelicista e o anti- imperialismo de Stokely Carmichael}

"Nós [do SNCC] estamos levantando questões a respeito deste país. Eu não quero fazer parte da torta americana [american pie]. A torta americana significa violentar a África do Sul, agredir o Vietnã, agredir a América do Sul, violentar as Filipinas, violentar todo o mundo por onde você passar. Eu não quero seu dinheiro de sangue. Eu não quero fazer parte dessa sociedade. Nós somos a geração que se deu conta de que este país é uma potência mundial, o país mais rico do mundo. Devemos questionar se queremos ou não que continue sendo o país mais rico do mundo às custas do abuso de todos os demais". 308

Em meados da década de 1960, a emergência de uma enorme resistência estudantil, pacifista e radical ao envolvimento norte-americano na Guerra do Vietnã tomou o país de assalto. Somando-se ao desafio lançado pelo Black Power aos valores culturais e às instituições racistas da "América Branca", o movimento antibelicista colocou a narrativa da nação norte-americana mais uma vez à prova e dividiu gerações segundo linhas político-ideológicas muito bem demarcadas. $^{309}$

Combinados, esses dois grandes movimentos de dissenso abalaram profundamente a

308 "We are raising questions about this country. I do not want to be a part of the American pie. The American pie means raping South Africa, beating Vietnam, beating South America, raping the Philippines, raping everybody you've been in. I don't want your blood money. I don't want to be a part of that society. We are the generation who has found this country to be a world power and the wealthiest country in the world. We must question whether or not we want this country to continue being the wealthiest country in the world at the price of raping everybody else". CARMICHAEL, Stokely. Berkeley Speech. In:_. Stokely Speaks: From Black Power to Pan-Africanism. 2. ed. Lawrence Hill Books, 2007, p. 55-56. Itálicos nossos.

${ }^{309}$ Nos anos 1960, o debate em torno da Guerra do Vietnã aprofundou o fosso geracional que opunha o não-conformismo com o "modo de vida americano" (American way of life) de parte da juventude da década às perspectivas mais conservadoras e patrióticas das gerações de seus pais e avós. Como resultado, o período de "acomodação" política trazido pelo crescimento econômico do pós-Guerra e pela repressão macartista rompeu-se, dando origem a fraturas nas relações interpessoais e sociais em famílias, escolas, universidades, associações de bairro, dentre outros, que marcaram os contemporâneos da década de 1960. Para uma narrativa ficcional - e, no entanto, clássica - a respeito desses embates geracionais, cf. o célebre romance de Philip Roth: ROTH, Philip. Pastoral Americana. Companhia das Letras, 1998. 
consciência do público e das tropas norte-americanas até então convictos de que tanto o credo cívico (American Creed) quanto o papel desempenhado pelo país no mundo orientavam-se pelos princípios da inclusão social, igualdade e liberdade democráticas. Aos olhos de muitos dentro do movimento negro e da Nova Esquerda, sobretudo, a persistência da discriminação racial em ambiente doméstico e a escalada da violência contra os vietnamitas colocaram às claras as "duas facetas de um mesmo problema": a corrupção inerente aos "ideais fundadores da nação" e o caráter repressivo, militarista do Estado norte-americano. ${ }^{310}$ Assim, ao alimentar conexões entre racismo e imperialismo - e, até certo ponto, traçar aproximações entre as militâncias branca e negra - a Guerra do Vietnã representou o "ponto de partida" para que Stokely Carmichael e tantos outros de sua geração formulassem uma agenda anti-imperialista radical identificada ao terceiro-mundismo do período. ${ }^{311}$

Apesar de tornar-se uma pauta política central somente em meados da década de 1960, o envolvimento militar norte-americano no Vietnã era anterior e remetia às disputas por zonas de influência que, na transição dos anos quarenta para os cinquenta, consolidavam o mundo bipolar da Guerra Fria. Durante o período de ocupação japonesa durante a Segunda Guerra Mundial, o pequeno país do Sudeste Asiático testemunhou o nascimento de uma potente luta de libertação nacional liderada pelo Viet Minh, movimento independentista de orientação comunista que se opunha tanto à invasão nipônica quanto ao colonialismo francês vigente na região desde o século XIX. Comandado por Ho Chi Minh - “aquele que ilumina”, em vietnamita - o Viet Minh chegou a contar com o apoio inicial dos Estados Unidos que se interessavam pelo enfraquecimento do Japão, adversário contra o qual os Aliados lutavam na Guerra do Pacífico.

No entanto, terminada a Segunda Guerra Mundial, o cenário havia mudado: a aliança antifascista firmada com os soviéticos foi desfeita e os norte-americanos voltaram-se à recuperação econômica e ao estreitamento dos laços com a Europa Ocidental como forma de barrar qualquer influência de Moscou no continente. Com isso, uma vez expulsos os ocupantes japoneses, o governo norte-americano optou por ignorar os numerosos apelos de apoio à independência vietnamita enviados por Ho Chi Minh e aliou-se às pretensões francesas pela retomada do controle colonial no Sudeste Asiático. ${ }^{312}$

\footnotetext{
${ }^{310}$ GERSTLE, Gary. op. cit., p. 312.

${ }^{311}$ ELBAUM, Max. op. cit., p. 42-43.

312 ISSERMAN, Maurice; KAZIN, Michael. America Divided: The Civil War of the 1960s. Oxford University Press, 2000, p. 68-71.
} 
À época, para os estrategistas dos presidentes Harry Truman (1945-1953) e Dwight Eisenhower (1954-1961), o apoio à brutal colonização francesa no Vietnã justificava-se como uma medida supostamente necessária para conter o avanço do comunismo na região. Alarmados pela ascensão de Mao Tsé-Tung ao poder na China em 1949 e a subsequente invasão da Coréia do Sul pelas forças de Kim Il-Sung, os norte-americanos acreditavam que, caso o Vietnã caísse nas mãos do Viet Minh, os demais países vizinhos também sucumbiriam à órbita comunista como resultado de um "efeito dominó". Temendo, portanto, que uma eventual ascensão de Ho Chi Minh ao poder no Vietnã significasse a derrocada da zona de influência capitalista na Ásia, os Estados Unidos ampliaram progressivamente sua intervenção no Vietnã fornecendo material bélico, dinheiro e treinamento aos colonialistas a ponto de, em 1954, momento da rendição francesa em Dien Bien Phu, arcarem com cerca de oitenta por cento dos custos da guerra contra a independência vietnamita. ${ }^{313}$

Após a divisão do país na Conferência de Genebra em 1954, ano em que os colonialistas franceses foram derrotados, os Estados Unidos subsidiaram a criação de um governo fantoche e autocrático liderado pelo católico anticomunista Ngo Dinh Diem em Saigon, a capital do recémformado Vietnã do Sul, como forma de fazer frente às forças de Ho Chi Minh em Hanoi, capital do Vietnã do Norte. À medida que Saigon intensificava a repressão contra quaisquer suspeitos de afiliação ao Viet Minh, ficou claro aos combatentes da independência no Sul - a quem os norteamericanos e os adeptos do regime sulista chamavam de "vietcongues", uma forma depreciativa de "vietnamitas comunistas" - que Diem jamais permitiria a unificação do país por meio das eleições gerais previstas para 1956. Como consequência, os focos guerrilheiros renovaram-se nas áreas rurais do Sul atraindo, também, veteranos do Viet Minh do Norte que ali chegavam pela "Trilha de Ho Chi Minh", complexo de caminhos percorrendo o Laos e o Camboja que abasteciam tanto a recém-criada FNL - Frente Nacional de Libertação (1960) quanto as tropas revolucionárias de Hanoi. ${ }^{314}$

A princípio, durante a presidência de John F. Kennedy (1961-1963), a resposta norteamericana aos avanços da FNL contra o regime sulista voltou-se ao apoio logístico e tecnológico das forças de Diem e ao envio de forças especiais - os green berets ou "boinas verdes" - para treinamento do campesinato em operações de contra-insurgência como emboscadas e ataques

${ }^{313}$ Ibidem, p. 71; MUNHOZ, Sidnei. op cit., p. 458-462; SOUSA, Rodrigo Farias de. A Nova Esquerda Americana: De Port Huron aos Weathermen (1960-1969). Rio de Janeiro: Editora FGV, 2009, p. 189.

${ }^{314}$ SOUSA, Rodrigo Farias de. op. cit., p. 190; ISSERMAN, Maurice; KAZIN, Michael. op cit., p. 75. 
surpresas contra os "vietcongues". A ideia inicial de utilizar o próprio exército do Vietnã do Sul nos combates com os norte-americanos oferecendo apoio tático e, em alguns casos, aéreo, mostrou-se ineficaz: desmotivadas e malpreparadas, as forças sulistas sofriam derrotas consecutivas que ameaçavam o já instável e impopular regime de Diem. Aos poucos, os recursos e efetivos norte-americanos se faziam mais necessários para fazer frente à obstinação e ao crescimento da FNL, levando o governo de Kennedy a aumentar o número de "conselheiros militares" no Vietnã para 11,000 em 1963. Aos poucos, o conflito indireto assumia o caráter de uma guerra de amplas proporções que, mobilizando uma logística cada vez mais vultuosa, começava a atrair o escrutínio do público norte-americano. ${ }^{315}$

O estopim de uma guerra prolongada e direta deu-se quando, em agosto de 1964, o destroier norte-americano Maddox foi atacado por torpedeiros vietnamitas no Golfo de Tonkin. A despeito das circunstâncias nebulosas que pautaram o embate - a princípio oficiais norteamericanos não sabiam ao certo se os vietnamitas haviam feito disparos ou se a leitura dos radares fora perturbada por condições meteorológicas adversas - o presidente Lyndon Johnson utilizou o episódio como pretexto para retaliar com força em uma operação contra bases inimigas que durou cinco horas e deixou um aviador norte-americano morto e outro prisioneiro. Capitalizando sobre o incidente em meio à corrida presidencial contra o republicano Barry Goldwater, Johnson valeu-se do apoio da opinião pública à retaliação norte-americana para solicitar ao Congresso que aprovasse a Resolução do Golfo de Tonkin, medida que lhe conferia amplos poderes para expandir o esforço de guerra no Vietnã. E, uma vez eleito, foi justamente isso que ele fez: em 1965, anunciando a escalada do conflito, os Estados Unidos deram início à operação Rolling Thunder ("trovão rolante"), o bombardeio sistemático e sem precedentes de alvos no Vietnã do Norte, seguido de um aumento astronômico e contínuo dos efetivos militares norte-americanos no país - de 184 mil pessoas em 1965 o número explodiria para mais de meio milhão em $1968 .^{316}$

Nos anos subsequentes, as ações norte-americanas contra o Vietnã assumiram suas facetas mais traumáticas e contestadas dentro e fora do país. Enquanto populações campesinas eram realocadas de seus vilarejos ancestrais à força para evitar "infiltrações de comunistas da FNL",

\footnotetext{
${ }^{315}$ SOUSA, Rodrigo Farias de. op. cit., p. 191; ISSERMAN, Maurice; KAZIN, Michael. op. cit., p. 78-82.

${ }^{316}$ Calcula-se que, entre 1965 e 1967, os aviões norte-americanos tenham lançado mais bombas sobre o território do Vietnã do que em todos os palcos de conflitos da Segunda Guerra Mundial. SOUSA, Rodrigo Farias de. op. cit., p. 194; ISSERMAN, Maurice; KAZIN, Michael. op. cit., p. 113-114.
} 
áreas inteiras foram devastadas pelo emprego de armas químicas como o "agente laranja", um desfolhante tóxico que destruía a cobertura vegetal da selva vietnamita sob a qual os guerrilheiros e civis se ocultavam, e pelo napalm, composto incendiário de terríveis efeitos no corpo humano. Como um todo, até o final do conflito em 1975, a utilização de tamanho arsenal bélico acarretou um número extraordinário de baixas: estima-se que quatro milhões de vietnamitas - dentre combatentes e, principalmente, civis no Sul e no Norte - foram mortos e, do lado norteamericano, cerca de 58 mil perderam suas vidas e mais de 300 mil voltaram feridos para os Estados Unidos. ${ }^{317}$

Como consequência, para além de dizimar o Vietnã, a guerra cindiu os Estados Unidos por dentro. Amplamente televisionado e reportados pela mídia impressa, os horrores do conflito chocaram uma ampla audiência nacional por meio de inúmeras imagens retratando a violência e os abusos contínuos vivenciados pelos vietnamitas - como, por exemplo, nos casos da notória auto-imolação do monge budista Thích Quảng Đức em 1963 e do massacre de Mỹ Lai em 1968. ${ }^{318}$ Somando-se a esses episódios, à medida que o recrutamento militar obrigatório e as baixas se intensificavam, um número cada vez maior de jovens veteranos voltavam para casa mutilados e/ou profundamente abalados pelo que presenciaram na guerra enquanto outros tantos soldados mortos eram velados envoltos na bandeira norte-americana. Com o tempo, todos esses fatores foram decisivos para que parte significativa da opinião pública, a princípio favorável à intervenção norte-americana, se voltasse contra o conflito e contra o governo de Lyndon Johnson.

Não tardou, portanto, para que as primeiras manifestações de resistência surgissem. Entre 1965 e 1966, um incipiente movimento antibelicista despontava entre o SNCC - uma das primeiras organizações a se manifestar publicamente contra a guerra e o recrutamento militar compulsório em janeiro de 1966 - e a Nova Esquerda, alimentando os quadros da militância estudantil branca na SDS e mobilizando protestos e ocupações de campi univesitários em Michigan, Berkeley, Madison, dentre outros. Gravitando em torno de uma crescente agenda

${ }^{317}$ SOUSA, Rodrigo Farias de. op. cit., p. 191; 194-195.

318 À época, protestando contra os assassinatos e prisões realizados pela polícia secreta do Vietnã do Sul contra monges budistas, Quảng Đức e diversos monges cometeram suicídio em via pública de Saigon cobrindo-se de gasolina e ateando fogo ao próprio corpo. Retrato assustador do governo ilegítimo e insustentável de Diem apoiado pelos Estados Unidos, a fotografia tirada da auto-imolação de Đức foi capa de jornais em todo o mundo recebendo o prêmio Pulitzer de 1963. Pouco tempo depois, Diem foi derrubado e assassinado por um golpe de Estado. Em março de 1968, um destacamento da infantaria norte-americana adentrou o vilarejo de My Lai à procura de "vietcongues" e massacrou 347 civis desarmados. O crime foi encoberto por oficiais militares por quase dois anos até vazar na imprensa norteamericana e escandalizar a opinião pública. ISSERMAN, Maurice; KAZIN, Michael, p. 97-98; 224. 
"anti-americana", muitos ativistas do período passaram a ver na Guerra do Vietnã o exemplo mais preemente de um longo histórico de intervenções militares e golpes de Estado patrocinados pela CIA no Terceiro Mundo - Guatemala (1954), Haiti (1957), a invasão da Baía dos Porcos em Cuba (1961), Congo (1962), Brasil (1964), República Dominicana (1965). Em outras palavras, ficava cada vez mais evidente à geração de Carmichael que a política externa norte-americana supostamente voltada à "contenção do comunismo" e à "defesa do mundo livre" serviam, em realidade, de pretexto à afirmação da hegemonia política e dos interesses capitalistas "ianques" em terras estrangeiras a todo e qualquer custo. ${ }^{319}$

No princípio do movimento antibelicista, Stokely Carmichael desempenhou, como presidente do SNCC, um papel de destaque na articulação de uma crítica anti-imperialista radical à política externa norte-americana. ${ }^{320}$ Já em meados de 1966, enquanto membros da SDS e de outros grupos da Nova Esquerda ainda se viam às voltas quanto à forma e os caminhos que a oposição à Guerra deveria trilhar, o ativista estabelecia conexões entre a luta pelo Black Power, o conflito no Vietnã e os processos de libertação no Terceiro Mundo. Exemplo disso, no mencionado artigo Power and Racism publicado em setembro daquele ano, Carmichael denunciava os Estados Unidos como um "polvo de exploração" cujos "tentáculos" estendiam-se “do Mississippi e do Harlem até a América do Sul, o Oriente Médio, a África do Sul e o Vietnã" garantindo que "alguns poucos poderosos se mantenham e enriqueçam às custas das massas nãobrancas pobres e sem voz". Era preciso quebrar esse padrão, alertou o ativista, pois "à medida que suas garras se afrouxam aqui e ali em todo o mundo, as esperanças dos negros americanos se tornam mais realistas". 321

Em pouquíssimo tempo, a analogia traçada por Carmichael e pelo SNCC entre as lutas afro-americana e vietnamita atraiu também os universitários brancos da Nova Esquerda interessados em tornarem-se parte do combate doméstico e terceiro-mundista contra o "Império Americano". Convocando os estudantes a resistirem ativamente ao alistamento obrigatório - uma

319 GENEROSO, Lidia Maria de Abreu. op. cit., p. 27; ELBAUM, Max. op. cit., p. 43 e CARSON, Clayborne. op. cit., p. 187-188.

${ }^{320}$ JOSEPH, Peniel E. op cit., 2014, p. 157-158

${ }^{321} \mathrm{Na}$ íntegra: "For a century, this nation has been like an octopus of exploitation, its tentacles stretching from Mississippi and Harlem to South America, the Middle East, southern Africa, and Vietnam; the form of exploitation varies from area to area but the essential result has been the same - a powerful few have been maintained and enriched of the poor and voiceless colored masses. This pattern must be broken. As its grip loosens here and there around the world, the hopes of black Americans become more realistic. For racism to die, a totally different America must be born". CARMICHAEL, Stokely. Power and Racism. In: . op. cit., 2007, p. 23. 
posição arriscada e ainda muito evitada, pois constituía ato ilegal passível de prisão e multas Stokely figurava, então, como um dos principais articuladores de uma postura militante em relação ao conflito no Vietnã que, nos anos seguintes, se difundiria ainda mais sob influência, também, do Partido dos Panteras Negras. ${ }^{322}$

Não por acaso, em outubro de 1966, alguns meses após lançar um manifesto anti-guerra com o líder da SDS Carl Oglesby, Carmichael dirigiu-se à University of California em Berkeley onde, perante um público estudantil majoritariamente branco, realizou o seu mais contundente discurso em prol de uma luta antibelicista comum entre as esquerdas norte-americanas. $\mathrm{Na}$ ocasião, reconhecendo a dificuldade em desmontar a "instituição da Guerra" no país, o ativista apelava aos estudantes que ao menos recusassem o serviço militar, pois, lembrava ele, "o único poder que nós temos é o poder de dizer 'De jeito nenhum!' ao alistamento". 323

“A guerra no Vietnã é ilegal e imoral. A questão é: o que podemos fazer para parar essa guerra? O que podemos fazer para impedir as pessoas que, em nome da América, estão matando bebês, mulheres e crianças? Temos que dizer a nós mesmos que existe uma lei maior do que a lei do tolo [Secretário de Estado] chamado [Dean] Rusk; existe uma lei maior do que a lei do bufão chamado [Lyndon B.] Johnson. É a lei de cada um de nós. Não vamos matar ninguém que eles dizem para matarmos e, se decidirmos matar, nós vamos decidir quem será. Este país só vai parar a Guerra no Vietnã quando os jovens que são obrigados a combatê-la começarem a dizer: 'De jeito nenhum, nós não vamos' [Hell no, we ain't going]'. 324

No entanto, em Berkeley, ao passo que o manifesto e as palavras de ordem contra a guerra - Hell No, We Won't Go - sugeriam uma rara sinalização do líder do Black Power à Nova Esquerda, Carmichael não se furtou a expor as diferenças que, como vimos no capítulo anterior, pautavam sua tênue relação com "aliados brancos". Provocando seus ouvintes, Stokely desafiou a

${ }^{322}$ BLOOM, Joshua; MARTIN Jr., Waldo E. op. cit., p. 128-130.

${ }^{323} \mathrm{Na}$ íntegra: "We do not have the power in our hands to change the institution of war in this country - to begin to recreate it so that they learn to leave the Vietnamese people alone. The only power we have is the power to say, 'Hell, no!' to the draft". CARMICHAEL, Stokely. Berkeley Speech. In: op. cit., 2007 , p. 52.

324 "The War in Vietnam is illegal an immoral. The question is, What can we do to stop that war? What can we do to stop the people who, in the name of America, are killing babies, women, and children? We have to say to ourselves that there's a higher law than the law of a fool named Rusk; there's a higher law than the law of a buffoon named Johnson. It's the law of each one of us. We will not murder anybody who they say kill, and if we decide to kill, we're going to decide who it shall be. This country will only stop the war in Vietnam when the young men who are going to fight it begin to say, 'Hell, no, we ain't going". Ibidem, p. 52-53. Itálico do autor. 
plateia de estudantes da SDS presentes no comício - a qual se referiu jocosamente como o "gueto branco intelectual do Oeste" - a combater o racismo em suas comunidades e a organizar a resistência ao alistamento militar para além do espaço acadêmico que lhes era familiar e “confortável". Segundo ele, "o movimento pacifista tem sido um fracasso porque não saiu dos campi universitários onde todo mundo tem uma 2S [dispensa militar para estudantes] e, de qualquer maneira, não tem medo de ser convocado". 325 Uma vez que os negros haviam construído sua própria luta contra o "sistema americano", então o que restava saber, provocou o ativista, era: "será que as pessoas brancas terão a coragem de ir às suas comunidades e começar a organizá-las? Esta é a questão para o ativista branco". 326

"Os brancos que se consideram ativistas estão prontos para se mudar para as comunidades brancas em um estalar de dedos, a construírem novas instituições políticas para destruir as antigas que temos e a se organizarem em torno da ideia de jovens brancos se recusando a entrar para o exército? Se sim, então podemos começar a construir um novo mundo. Precisamos urgi-los para lutarem agora e serem os líderes de hoje, não de amanhã. Este país é uma nação de ladrões. Está à beira de se tornar uma nação de assassinos. Nós precisamos pará-lo. Nós precisamos pará-lo. Nós precisamos pará-1o". 327

Conforme indicado pelas suas críticas à SDS e à Nova Esquerda branca, as pautas antibelicistas defendidas por Carmichael eram atravessadas por um recorte racial e comportavam preocupações específicas para a população e o ativismo negros. Isso ficou ainda mais evidente em janeiro do ano seguinte, momento no qual Stokely deslocou-se para a Morgan State University em Baltimore, estado de Maryland, onde tratou do tema da Guerra perante um público de universitários negros de classe média. Na ocasião, Carmichael falava aos seus "pares",

\footnotetext{
325 "The peace movement has been a failure because it hasn't gotten off the college campuses where everybody has a $2 \mathrm{~S}$ and is not afraid of being drafted anyway". Ibidem, p. 53.

${ }^{326} \mathrm{Na}$ íntegra: "How can you, as the youth in this country, move to start carrying those things out? Move into the white community. We have developed a movement in the black community. The white activist has miserably failed to develop the movement inside of his community. Will white people have the courage to go into white communities and start organizing them? That's the question for the white activist". Ibidem, p. 57.

327 "Are white people who call themselves activists ready to move into the white communities on two counts, on building new political institutions to destroy the old ones that we have, and to move around the concept of white youth refusing to go into the army? If so, than we can start to build a new world. We must urge you to fight now to be the leaders of today, not tomorrow. This country is a nation of thieves. It stands on the brink of becoming a nation of murderers. We must stop it. We must stop it. We must stop it". Ibidem, p. 59-60.
} 
estudantes com os quais nutria uma proximidade marcadamente distinta daquela mostrada perante a esquerda branca em Berkeley. ${ }^{328}$ Em especial, tratava-se ali de reforçar uma linha de continuidade entre a agenda político-identitária do Black Power e a oposição antibelicista, desvelando os laços que ligavam o racismo sistêmico sofrido pelo público negro ouvinte à supressão do direito dos vietnamitas à autodeterminação. Sob essa ótica, para o ativista e tantos outros dentro do Movimento Black Power, o conflito comportava contornos nitidamente racistas e genocidas na medida em que recrutava compulsoriamente um número desproporcional de negros para lutar contra outro "povo não-branco" e morrer por uma suposta "liberdade" que sequer lhes era assegurada em solo norte-americano. ${ }^{329}$

Assim, subindo o tom de suas denúncias, em Baltimore, Carmichael atribuía às ações norte-americanas na Indochina o status de crime contra a Humanidade e caracterizava a resistência negra ao alistamento como um dever da "ordem da consciência" atravessado por profundas implicações morais. Ou seja, era preferível, alertava ele, que os estudantes negros se submetessem à prisão do que lutassem em uma guerra ilegítima como "mercenários" a mando do "homem branco". 330

“A Guerra no Vietnã deve interessar a vocês não apenas individualmente, mas também porque ela é muito política para as pessoas negras. Quando [o Secretário da Defesa Robert] McNamara diz que vai convocar 30 por cento dos negros do gueto [para lutar], meu bem, isso não é nada além de remoção urbana. Vocês devem se dar conta de que vocês serão os companheiros que liderarão as investidas do seu povo negro. Vocês têm a coragem de se levantar agora e dizer 'eu não vou seguir a lei e a ordem, eu vou seguir minha própria consciência'? Foi por isso que eles enviaram [o oficial nazista Adolf] Eichmann à prisão, vocês sabem, porque ele seguia a lei e a ordem". As escolhas são muito claras: ou vocês sofrem ou infligem sofrimento. Ou você vai para a penitenciária federal de Leavenworth no Kansas ou você se torna um assassino. Eu escolherei sofrer. Eu vou para a cadeia. Este país que vá para o inferno". 331

\footnotetext{
${ }^{328}$ Cf. o discurso em CARMICHAEL, Stokely. At Morgan State. In: op. cit., 2007, p. 61-76.

${ }^{329}$ Para uma discussão das motivações que levaram a militância do Movimento Black Power a resistir à Guerra do Vietnã, cf. VAN DEBURG, William L. op. cit., p. 98-100.

${ }^{330}$ CARMICHAEL, Stokely. Berkeley Speech. In: op. cit., 2007, p. 53.

331 "The war in Vietnam should have interest for you not only personally, but also because it is very political for black people. When McNamara says he is going to draft 30 per cent of the black people out of the ghettos, baby, that is nothing but urban removal. You should realize you are going to be the fellows leading the charges of your black people. Do you have the guts to stand up now and say I will not follow law and order, I will follow my own conscience. That's what they sent Eichmann to jail for, you know,
} 
Nesse ponto, Stokely e o movimento antibelicista ganharam um aliado de grande estatura para a resistência à Guerra na figura de Martin Luther King Jr. Em 4 abril de 1967, contrariando o governo Johnson e seus aliados do establishment liberal dos Direitos Civis - dentre eles, Bayard Rustin e a NAACP -, o pastor batista e vencedor do Prêmio Nobel da Paz de 1964 somou-se à luta ao colocar-se pública e contundentemente contra a Guerra no icônico discurso Beyond Vietnam: A Time to Break Silence, pronunciado no púlpito da Riverside Church, em Nova York. Convocando os ouvintes a se posicionarem como "objetores de consciência" ao serviço militar, King classificou o envolvimento norte-americano no Vietnã como "desonroso" e defendeu cinco iniciativas a serem tomadas para encerrar a guerra: a interrupção imediata dos bombardeios; uma declaração unilateral de cessar-fogo por parte dos Estados Unidos; a desmobilização dos efetivos e aparatos militares norte-americanos na Tailândia e em Laos; o reconhecimento da legitimidade da FNL e a abertura de negociações com seus líderes; a definição de uma data para a retirada das tropas norte-americanas do território vietnamita em consonância com os Acordos de Genebra de $1954 .^{332}$

Colocando-se como um "irmão dos pobres que sofrem no Vietnã", King criticou duramente os vultuosos recursos destinados por Washington ao conflito, responsabilizando-o pelo esvaziamento das agendas governamentais de combate à pobreza e fomento da inclusão social que constituíam o carro-chefe da "Grande Sociedade" anunciada por Lyndon Johnson alguns anos atrás. Segundo ele, "uma nação que continua, ano após ano, a gastar mais dinheiro com defesa militar do que com programas de assistência social está se aproximando da sua morte espiritual". ${ }^{333}$ Pautada por um viés anticapitalista e uma visão anti-imperialista crescentes, a fala de King traduzia a postura cada vez mais crítica à pobreza, ao racismo e à política externa norteamericana assumida pelo pastor batista. Até o seu assassinato durante uma greve de trabalhadores sanitaristas na cidade de Memphis, em 1968, King estabeleceria pontos de convergência com Stokely Carmichael e parte da militância do Movimento Black Power ao conclamar por uma

because he followed law and order. The choices are very clear: you either suffer or you inflict suffering. Either you go to Leavenworth federal penitentiary in Kansas or you become a killer. I will choose to suffer. I will go to jail. To hell with this country”. CARMICHAEL, Stokely. At Morgan State. In: op. cit., 2007, p. 75-76. Itálicos nossos.

${ }^{332}$ KING JR., Martin Luther. Beyond Vietnam. In:___ CARSON, Clayborne (ed.). A Call to Conscience: The Landmark Speeches of Martin Luther King, Jr. New York: Warner Books, 2001, p. 154156.

333 Ibidem, p. 153. 
"revolução nos valores" e na consciência nacionais contra os tripés do "racismo, materialismo extremo e militarismo". 334

"A guerra no Vietnã é apenas um sintoma de uma doença muito mais profunda dentro do espírito americano e, se ignorarmos essa realidade preocupante, [...] nos veremos organizando comitês de 'clérigos e leigos preocupados' para as próximas gerações. Eles se preocuparão com a Guatemala e o Peru. Eles ficarão preocupados com a Tailândia e o Camboja. Eles se preocuparão com Moçambique e a África do Sul. Nós marcharemos por esses e uma dúzia de outros nomes e participaremos de comícios sem fim a menos que haja uma mudança significativa e profunda na vida e na política [norte-]americanas". 335

Fomentada pelo posicionamento do SNCC, pelos discursos de Carmichael e King e pelo engajamento da Nova Esquerda branca, a resistência contra a Guerra crescia no país, tornando-se mais disseminada e combativa. Em abril de 1967, poucos dias após o posicionamento na Riverside Church, King, Carmichael e cerca de duzentas e cinquenta mil marcharam do Central Park à sede das Nações Unidas em Nova York ao lado do cantor e ator Harry Belafonte, Floyd Mckissick do CORE e James Bevel da SCLC em uma das maiores demonstrações antibelicistas da história dos Estados Unidos. No mês de outubro, durante a "Semana de Parar com o Alistamento" (Stop the Draft Week), uma série de protestos foram organizados em mais de 30 cidades: ao passo que manifestantes na cidade de Oakland recorriam a barricadas, queima de documentos militares e confrontos com a polícia, em Washington, uma marcha com cerca de 30 mil pessoas - entre estudantes radicais da SDS, pacifistas e hippies - seguiu até o Pentágono onde foi dispersada pela Guarda Nacional. Ao mesmo tempo, enquanto bandeiras da FNL começaram a colorir os atos antibelicistas ao som das provocativas palavras de ordem "Ho, Ho, Ho Chi Minh / A FNL vai vencer!", muitos manifestantes voltaram-se contra o complexo industrial-militar, atacando a cumplicidade das universidades com empresas como a Dow

334 Ibidem, p. 157-158. Sobre o posicionamento de Martin Luther King contra a guerra, cf. também ELBAUM, Max. op. cit., p. 23-24 e KING JR., Martin Luther; CARSON, Clayborne (org.). $A$ autobiografia de Martin Luther King. Rio de Janeiro: Zahar, 2014, p. 392-407.

335 "The wat in Vietnam is but a symptom of a far deepder malady within the American spirit, and if we ignore this sobering reality, $[\ldots]$ we will find ourselves organizing 'clergy and laymen concerned' committees for the next generation. They will be concerned about Guatemala and Peru. They will be concerned about Thailand and Cambodia. They will be concerned about Mozambique and South Africa. We will be marching for these and a dozen other names and attending rallies without end unless there is a significant and profound change in American life and policy". KING JR., Martin Luther; CARSON, Clayborne (ed.). op. cit., 2001, p. 156. 
Chemical, fabricante do napalm. ${ }^{336}$

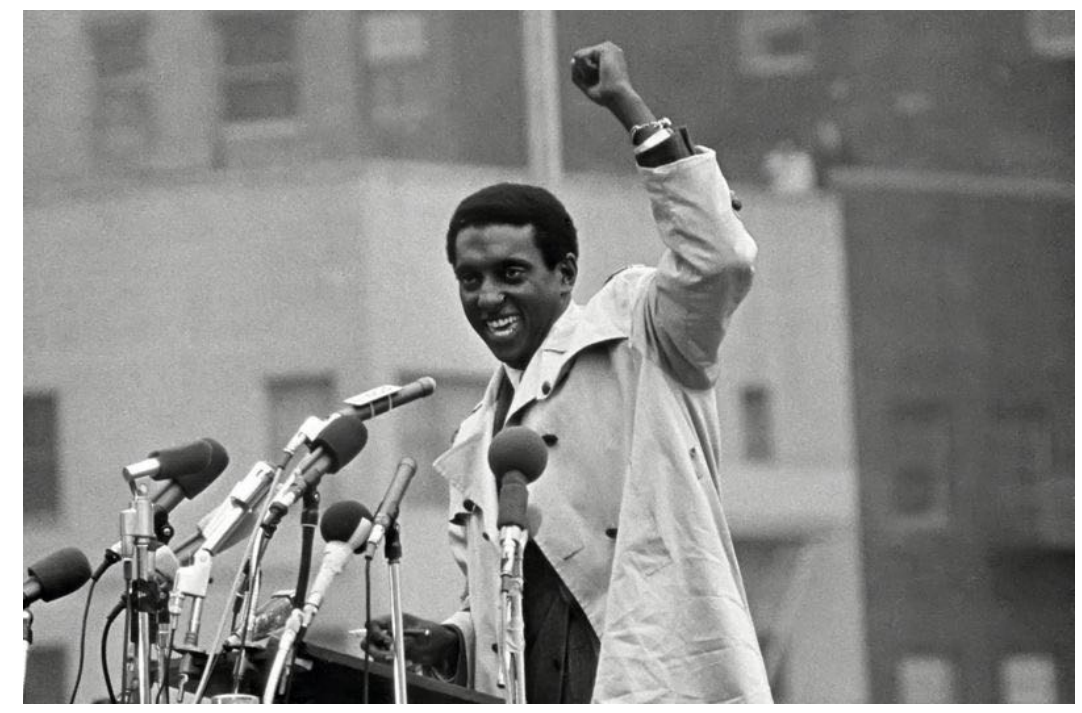

Imagem 10 - Em abril de 1967, Stokely Carmichael discursa contra a Guerra do Vietnã em frente à sede das Nações Unidas, na cidade de Nova York, em um dos maiores comícios antibelicistas da década. Fonte: Getty Images. Disponível em: <https://www.gettyimages.com/detail/news-photo/stokely-carmichaelattends-an-anti-vietnam-war-rally-at-the-news-photo/631774301>. Acesso em: 10 de março de 2019.

Em suma, o movimento antibelicista se radicalizava, difundindo-se por distintos setores da sociedade norte-americana que incluíam desde militantes do movimento Black Power, universitários brancos e veteranos das forças armadas até líderes religiosos, celebridades, hippies, dentre outros. Àquela altura, a resistência de Stokely Carmichael à Guerra contribuíra para informar os contornos de uma ampla agenda anti-imperialista radical que, construída no ativismo multifacetado que envolvia as esquerdas no seio da maior potência global, projetava-se como um braço doméstico solidário às resistências contra os "ianques" mundo afora. Nesse contexto, identificando-se à causa dos vietnamitas do Norte e conectando a resistência antibelicista às aspirações do Movimento Black Power no país, Carmichael alargava o escopo de seu projeto e o horizonte da luta política afro-americana. Em maio de 1967, movido por um internacionalismo e um anti-imperialismo crescentes, o ativista deixou a presidência do SNCC e, durante o segundo semestre daquele ano, lançou-se à cena transnacional.

\footnotetext{
${ }^{336}$ ISSERMAN, Maurice; KAZIN, Michael. op. cit., p. 183-186 e SOUSA, Rodrigo Faria de. op. cit., p. 234-242.
} 


\subsection{2. "Terceiro Mundo, nosso mundo": solidariedades revolucionárias, anticapitalismo e antirracismo em Londres e Havana}

"Estamos trabalhando para aumentar a consciência revolucionária dos negros nos Estados Unidos para eles se unirem ao Terceiro Mundo. O uso ou não da violência não é decidido por nós, mas pelo Ocidente Branco. Estamos lutando uma guerra política. A política é guerra sem violência. A guerra é política com violência. O Ocidente Branco tomará a decisão sobre como eles querem que a guerra política seja travada. Não vamos mais curvar nossas cabeças para nenhum homem branco. Se ele tocar em um homem negro nos Estados Unidos, ele vai entrar em guerra com todos os homens negros nos Estados Unidos". 337

Entre os meses de julho e dezembro de 1967, Stokely Carmichael embarcou em um intenso tour internacional durante o qual percorreu países da Europa e, principalmente, do "Terceiro Mundo", como um "representante não-oficial” do movimento negro norte-americano. Discursando perante públicos muito diversos, as viagens de Carmichael por Inglaterra, Cuba, Argélia e Guiné - além de passagens por Minsk, Moscou, Hanoi, Beijing, Cairo, Damasco, Dar es Salaam (Tanzânia), distintas cidades escandinavas e, por último, Paris - radicalizaram ainda mais o ativista ao possibilitarem sua interação com figuras-chave da esquerda mundial e consolidarem-no como uma liderança internacionalmente reconhecida. Intercâmbios travados com Fidel Castro, Ho Chi Minh, membros da Frente de Libertação Nacional argelina, o presidente guineense Ahmed Sékou Touré e o ganês Kwame Nkrumah, dentre outros, reforçaram em Stokely a convicção de que a "violência revolucionária" constituía um corolário necessário às transformações sociais e políticas pretendidas pelo Black Power nos Estados Unidos. ${ }^{338}$

Em suas duas primeiras paradas em Londres e Havana, ao aproximar a agenda do Black Power das pautas e plateias às quais se dirigia, Stokely circulou por distintos espaços nos quais intelectuais e militantes sociabilizavam e cruzavam fronteiras entre os mundos da academia e da política. Nessas ocasiões, travando solidariedades políticas com as esquerdas internacionais, o ativista vinculava a luta afro-americana às pretensões socialistas dos terceiro-mundistas ao

337 "We are working to increase the revolutionary consciousness of black people in America to join with the Third World. Whether or not violence is used is not decided by us, but by the white West. We are fighting a political warfare. Politics is war without violence. War is politics with violence. The white West will make the decision on how they want the political war to be fought. We are not any longer going to bow our heads to any white man. If he touches one black man in the United States, he is going to war with every black man in the United States". CARMICHAEL, Stokely. The Dialectics of Liberation. In: Stokely Speaks: From Black Power to Pan-Africanism. 2. ed. Lawrence Hill Books, 2007, p. 93.

338 JOSEPH, Peniel E. op. cit., 2014, p. 197. 
afirmar que "o capitalismo e o racismo andam de mãos dadas" e, portanto, "a sociedade que procuramos construir entre os negros não é uma sociedade capitalista opressora". 339

Por outro lado, como veremos a seguir, as falas de Carmichael deixavam transparecer, também, os limites das afinidades político-ideológicas estabelecidas pelo militante durante suas viagens. Ancorado na particularidade das experiências negras e de outros povos oprimidos pela "civilização" ocidental, o projeto político do ativista tensionava postulados clássicos do materialismo histórico marxista em favor da luta contra o racismo empreendida pelo Black Power: "nossa interpretação de Marx vem não apenas de sua escrita, mas, como a entendemos, da relação dos países capitalistas com as populações de cor [people of color] por todo o mundo". 340

Em meados de julho de 1967, Carmichael aterrisou em Londres, onde foi convidado para discursar no Congresso da Dialética da Libertação, evento que reuniu, em uma inusitada experiência contracultural, dissidentes do East Side de Nova York com radicais europeus dos campos da arte, política, literatura e psiquiatria. ${ }^{341}$ Além de Carmichael, o Congresso contava com uma combinação eclética de expoentes intelectuais marxistas como o psicólogo norteamericano Paul Goodman; o filósofo alemão e referência intelectual da SDS Herbert Marcuse; o já mencionado historiador trinitino C. L. R. James; o economista nova-iorquino Paul Sweezy, além de ativistas influentes na contracultura dentre os quais se destacava o poeta pacifista e ícone literário da geração beat, Allen Ginsberg. ${ }^{342}$ Mobilizando ampla atenção no Reino Unido, o

${ }^{339} \mathrm{Na}$ íntegra: "A capitalist system automatically includes racism, whether by design or not. Capitalism and racism go hand in hand. The struggle for Black Power in the United States, and certainly around the world, is the struggle to free these colonies from external domination, but we do not seek merely to create communities where black rulers replace white rulers, controlling the lives of black masses, and where money goes into a few pockets. We want to see it go into the communal pocket - the society we seek to build among black people is not an oppressive capitalist society. Capitalism, by its very nature, cannot create structures free from exploitation" CARMICHAEL, Stokely. The Dialectics of Liberation. In: op. cit., p. 87.

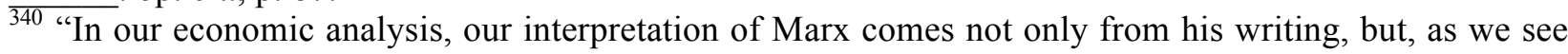
it, from the relationship of capitalistic countries to people of color around the world". Ibidem, p. 89-90.

${ }^{341}$ Recentemente, o discurso de Stokely no Congresso da Dialética da Libertação foi traduzido para o português pelo professor Amauri Mendes Pereira da Universidade Federal Rural do Rio de Janeiro. No entanto, aqui utilizamos a versão em inglês do documento compilado na coletânea Stokely Speaks. Para a versão brasileira já citada em outra ocasião, cf. PEREIRA, Amauri M. (org.); CARMICHAEL, Stokely. $O$ Poder Negro. 2a ed. Belo Horizonte: Ed. Nandyala, 2018.

342 Durante a década de 1950, jovens escritores boêmios de Nova York como Jack Kerouac, Allen Ginsberg e William S. Burroughs conceberam o movimento literário beat como uma forma de rebelaremse contra as convenções sociais e a opacidade da vida de classe média à sua volta. Procurando um desligamento da sociedade norte-americana mainstream, os beats recorriam à busca de vivências supostamente "autênticas" através da experimentação sexual, do uso de drogas, da exploração da 
evento assumiu um formato acadêmico no qual quadros políticos radicais e estudantes de distintas origens - provenientes de Berlim Ocidental, Noruega, Suécia, França, Nigéria, Cuba e outras ilhas do Caribe, Holanda, Estados Unidos, dentre outros - discutiam as relações entre "violência" e "revolução". Segundo os organizadores, os fóruns, conferências e debates abertos ao público voltavam-se ao tema central da "desmistificação da violência humana em todas as suas formas, dos sistemas sociais dos quais emana, e à exploração de novas formas de ação [política]". 343

Em meio a um espaço dominado pelas esquerdas europeia e norte-americana, Carmichael posicionou-se como um raro "porta-voz" do "Terceiro Mundo", trocando farpas e protagonizando duros embates com outros participantes e parte do público presente. Particularmente crítico da contracultura defendida por Ginsberg, Stokely rebateu o corolário hippie de que a "transformação da consciência e da cultura dominante" ocorreria pela via do pacifismo e da experimentação sensorial/espiritual. Para o ativista, o foco da luta não residia na "desalienação do indivíduo" contemporâneo - viés este também próximo ao adotado pelos psiquiatras existencialistas e por parte das esquerdas que organizaram o evento - mas na destruição dos sistemas dos quais a opressão emanava: a supremacia branca e o capitalismo. ${ }^{344}$

"Desde que cheguei ao Congresso, eu tenho me sentido muito confuso porque não sou psicólogo nem psiquiatra, sou ativista político. Eu não lido com o indivíduo, acredito que é um subterfúgio falar do indivíduo. $O$ [assunto] do qual nós estamos falando hoje nos Estados Unidos, e acredito que pelo Terceiro Mundo, é o sistema internacional da supremacia branca associado ao capitalismo internacional. Nós vamos

religiosidade oriental e da rejeição de padrões morais convencionais. Em sua busca por êxtase e separação do seu meio social, beats como Ginsberg lançaram as bases do que viria a conformar a "cultura jovem" da década de 1960. Naquele momento, a contracultura surgia, portanto, como um movimento entre jovens (em sua maioria brancos e da classe média) que buscavam dissociação dos valores norte-americanos básicos, recusando o militarismo, a ameaça nuclear e o "conformismo tecnocrático" presentes em sua sociedade em favor de formas alternativas de "consciência" individual e de organização da vida coletiva. Sobre os beats e a contracultura, cf. ISSERMAN, Maurice; KAZIN, Michael. op. cit., p. 147-151 e ROSZAK, Theodore. A Contracultura: reflexões sobre a sociedade tecnocrática e a oposição juvenil. São Paulo: Editora Vozes, 1972.

${ }^{343}$ Sobre o Congresso da Dialética da Libertação, cf. COOPER, David. Introduction. In: (ed.). The Dialectics of Liberation. London: Verso, 2015 e o website: $<$ http://www.dialecticsofliberation.com/1967dialectics/dialectics-introduction/>. Acesso em: 09 de maio de 2018. Ver também o documentário produzido durante o evento: Anatomy of Violence. Direção e Produção: Peter Davis. Reino Unido, 1967. (29 min). Disponível em: <https://www.youtube.com/watch? $\mathrm{v}=\mathrm{a}-\mathrm{MwCTctZxE}>$. Acesso em: 10 de maio de 2018.

${ }^{344}$ CARMICHAEL, Stokely; THELWELL, Ekwueme M. op. cit., p. 572-573. 
esmagar esse sistema. As pessoas que se enxergam como parte desse sistema serão esmagadas - isto ou nós seremos esmagados. [...] [Por isso,] A questão negra não se resume a negros individuais vivendo individualmente entre os brancos, mas sim dos negros como uma classe explorada, escravizada e desprezada pela sociedade capitalista colonialista, que é apenas acidentalmente branca. Mas como é acidentalmente branca, é dela que falamos: da sociedade ocidental branca". 345

No evento, portanto, o ativista endossou a convicção de que o mundo dividia-se não apenas segundo o binarismo dos blocos político-ideológicos das superpotências da Guerra Fria, mas também, de acordo com as experiências particulares do colonialismo e do imperialismo. Em sua visão, o mundo caminhava para um confronto armado iminente entre as forças do capitalismo e racismo ocidentais, de um lado, e os povos africanos, asiáticos e latino-americanos oprimidos, de outro. Dessa forma, na esteira d'Os Condenados da Terra, Carmichael colocava que a luta revolucionária pela "salvação da humanidade" seria "travada a partir do Terceiro Mundo" e protagonizada por sujeitos e vozes outras que não aquelas provenientes da Europa. Voltando-se à plateia que o ouvia, ele disparou: "haverá novos oradores; eles serão Che, serão Mao, serão Fanon. Vocês podem ficar com Rousseau, vocês podem ficar com Marx, vocês podem até ficar com o grande defensor da liberdade John Stuart Mill". 346

Enquanto a passagem de Carmichael por Londres provara-se tumultuosa, em Cuba, o ativista encontrou um ambiente mais receptivo às suas ideias. Na cidade de Havana, Stokely participou da conferência de fundação da OLAS - Organização Latino-Americana de Solidariedade, evento realizado entre 31 de julho e 10 de agosto de 1967 que contou com a presença de diversos grupos de esquerda da América Latina, bem como de delegados de

345 “Now, since I've been in the Congress I've been very confused, because I'm not a psychologist or a psychiatrist, I'm a political activist. I don't deal witht the individual, I think it's a cop-out when people talk about the individual. What we're talking about around the United States today, and I believe around the Third World, is the system of international white supremacy coupled with international capitalism. We are out to smash that system. People who see themselves as part of that system are going to be smashed with it - or we're going to be smashed. [...] The Negro problem does not resolve itself into the problem of individual Negroes living among white men, but rather of Negroes as a class that is exploited, enslaved, and despised by the colonialist, capitalist society, which is only accidentally white. But since it is accidentally white, that's what we talk about - white Western society". CARMICHAEL, Stokely. The Dialectics of Liberation. In: op. cit., p. 77-78.

346 "We are indeed fighting to save the humanity of the world, which the West has failed miserably to preserve. And the fight must be waged from the Third World. There will be new speakers. They will be Che, they will be Mao, they will be Fanon. You can have Rousseau, you can have Marx, you can even have the great libertarian John Stuart Mill”. Ibidem, p. 93-94. 
movimentos independentistas do "Terceiro Mundo" e representantes do bloco socialista.

Realizada na sequência da célebre Conferência Tricontinental de 1966, a OLAS surgia da busca do governo cubano pela promoção de uma agenda revolucionária que envolvesse a América Latina, África e Ásia no combate ao capitalismo, racismo e ao imperialismo ocidentais europeu e, particularmente, norte-americano. Em especial, a OLAS, cujo mote era "o dever do revolucionário é fazer a revolução", apostava na luta armada e na guerra de guerrilhas como maneira de aproximar as lideranças e movimentos de esquerda latino-americanos e exportar a experiência cubana por todo o continente. Nesse sentido, pautava-se pelos dizeres de Ernesto "Che" Guevara em sua Mensagem à Tricontinental na qual, postulando a inevitabilidade do confronto contra o imperialismo "ianque", o líder argentino defendera a criação de um "segundo ou terceiro Vietnã" nas Américas. ${ }^{347}$

A visita de Stokely Carmichael à Havana inseria-se em um histórico pregresso de aproximação e solidariedade política entre radicais negros norte-americanos e a Revolução Cubana. À época, muitos ativistas e intelectuais afro-americanos viam a bem-sucedida experiência revolucionária da ilha como uma fonte de inspiração para a sua resistência doméstica ao poderio imperial e às hierarquias raciais nos Estados Unidos. Em meio ao despertar das lutas do movimento negro contra a segregação e o racismo institucionalizado nas décadas de 1950 e 1960, a atração de militantes afro-americanos por Cuba justificava-se pela reputação antirracista que o regime buscava construir internacionalmente. Contudo, é importante ressaltarmos que, na prática, a postura antirracista do regime castrista não esteve livre de importantes contradições. Sabe-se hoje que, durante a década de 1960, segundo testemunhado pelo escritor, intelectual e ativista afro-cubano Carlos Moore, o governo cubano reprimia duramente as manifestações identitárias, religiosas e culturais negras na ilha. Identificados como críticos do regime e/ou contrarrevolucionários que divergiam da linha castrista, Moore e vários outros foram alvos de perseguições, prisões arbitrárias, trabalhos forçados e até execuções. ${ }^{348}$

347 SEIDMAN, Sarah. Tricontinental routes of solidarity: Stokely Carmichael in Cuba. Journal of Transnational American Studies, v. 4. n. 2, 2012, p. 1-2; 6 e GUEVARA, Ernesto Che. Mensagem à Tricontinental. In: LÖWY, Michael (org.). O Marxismo na América Latina: uma antologia de 1909 aos dias atuais. São Paulo: Fundação Perseu Abramo, 1999, p. 287.

${ }_{348}$ Nascido em 1942 em Cuba, Carlos Moore construiu uma trajetória de intenso engajamento com as lutas negras antirracistas em vigor nos anos 1960 e 1970 como o movimento pelos Direitos Civis, Black Power, a luta pan-africanista, dentre outras. Nesse percurso transnacional apoiou e, depois, foi perseguido pela revolução cubana ao criticar a continuidade da discriminação racial na ilha. Autor de diversas obras, Moore exilou-se e viajou pelo Atlântico Negro constantemente, aproximando-se de figuras-chave do 
Por outro lado, uma vez vitorioso em 1959, Castro banira formalmente a discriminação racial na ilha e, no ano seguinte, durante a realização da Assembleia Geral da ONU em Nova York, desafiara as hierarquias raciais norte-americanas ao hospedar sua delegação no Hotel Teresa - localizado no coração do bairro negro do Harlem - e encontrar-se com lideranças negras, dentre elas, Malcolm X. Por essas razões, portanto, uma imagem positiva do regime construíra-se entre boa parte da militância afro-americana da época. Assim, desde os primórdios da revolução cubana e durante todas as décadas de 1960 e 1970, figuras como o mencionado Robert F. Williams, ativista negro da NAACP adepto da autodefesa armada e referência importante para grupos como RAM e Partido dos Panteras Negras; Amiri Baraka, o já citado expoente do Black Arts Movement, braço cultural do Movimento Black Power; o pantera negra Huey Newton; a militante comunista Angela Davis e a guerrilheira Assata Shakur, dentre outros; dirigiram-se à Cuba como visitantes ou foragidos da repressão do Estado norte-americano às lideranças radicais do movimento negro. ${ }^{349}$

Em julho e agosto de 1967, a recepção calorosa dedicada a Stokely pelas autoridades cubanas em Havana gerou grande repercussão internacional, chocando observadores norteamericanos e colocando o Departamento de Justiça em estado de alerta. ${ }^{350}$ Em especial, a aproximação entre o ativista e Fidel Castro - que o levou por um tour de jipe pela Sierra Maestra, mostrando pontos e batalhas decisivas da guerra contra o regime de Fulgencio Batista - produziu especulações acerca de uma possível aliança entre a militância afro-americana do Black Power e a Revolução Cubana.

período, dentre elas, o poeta surrealista martiniquenho da Négritude Aimé Césaire, Malcolm X, a escritora afro-americana Maya Angelou, o grande ativista, intelectual, político e acadêmico negro brasileiro Abdias do Nascimento, Stokely Carmichael, dentre tantos outros. Acerca da perseguição sofrida por Moore em Cuba, cf. o depoimento na autobiografia MOORE, Carlos. Pichón: a memoir. Race and Revolution in Castro's Cuba. Chicago: Lawrence Hill Books, 2008. Ver, também, a recente entrevista concedida por ele ao jornal EL PAÍS: BRUM, Eliane. Um negro em eterno exílio. El País, 31 ago. 2015. Disponível em: $<$ https://brasil.elpais.com/brasil/2015/08/31/opinion/1441035388_761260.html>. Acesso em: 01 de abril de 2019.

349 Acerca das relações travadas entre ativistas e intelectuais afro-americanos e a Revolução Cubana, cf. YOUNG, Cynthia. Havana up in Harlem: LeRoy Jones, Harold Cruse and the making of a cultural revolution. Science \& Society, v. 65, n. 01, spring 2001, p. 12-38 e SEIDMAN, Sarah. op. cit., p. 2. Sobre Assata Shakur e o grupo clandestino Black Liberation Army do qual ela fazia parte, cf. BLOOM, Joshua; MARTIN Jr., Waldo E. op. cit., p. 386-389. Sobre o encontro de Castro e Malcolm X, cf. MARABLE, Manning. op. cit., 2013, p. 197-198.

350 Assim que Carmichael chegou em Cuba, o Departamento de Justiça dos Estados Unidos anunciou planos para confiscar o passaporte do militante. Nos meses seguintes, oficiais consulares norte-americanos tentaram, sem sucesso, reaver seu passaporte em distintos países pelos quais o militante passou. Cf. JOSEPH, Peniel E. op. cit., 2014, p. 205. 
Nos Estados Unidos, os veículos da grande imprensa condenaram - e, em grande medida, exageraram - o ocorrido. Jornalistas do Washington Post, por exemplo, acusaram o SNCC de ser “o braço-direito de Fidel Castro nos Estados Unidos”. O intelectual e apresentador de televisão William F. Buckley, um expoente central do movimento conservador nos Estados Unidos, afirmou que Carmichael estaria "dando aos comunistas [cubanos] um curso de pós-graduação na arte da revolução". ${ }^{351}$ Em 02 de agosto daquele ano, mesmo dia em que o Washington Post trouxe uma matéria de capa intitulada "Carmichael louva o comunismo cubano", o New York Times publicou um editorial chamando o ativista de "cínico". Para o jornal, o ativista estaria "não somente condenando o próprio país internacionalmente, como também enganando Fidel Castro [...] acerca da condição e do [real] poder detido pelos negros nos Estados Unidos". 352

Por sua vez, a imprensa cubana, em consonância com a política externa do governo castrista, realizava uma cobertura muito favorável do SNCC e, em particular, de Carmichael. Em suas edições, o Granma, periódico oficial do Estado cubano, demonstrava sua preferência pelos militantes radicais do SNCC em detrimento dos líderes reformistas dos Direitos Civis e dos separatistas da Nação do Islã, enaltecendo Stokely como o "ilustre líder da organização".353

Embora exacerbada pela imprensa como um todo, a aproximação entre Carmichael e Castro baseava-se no compromisso com uma agenda revolucionária anticapitalista, antiimperialista e antirracista comum presente na fala de ambos. Alinhando-se ao "tricontinentalismo" cubano, o discurso de Stokely na conferência não deixava margem para dúvidas: em Havana, diferentemente da ambivalência presente no livro Black Power, o ativista clamava que era hora dos "condenados da Terra" pegarem em armas para lutar contra seu inimigo comum, a "sociedade ocidental branca imperialista". Afinal, segundo ele reforçaria em um artigo publicado na Revista Tricontinental logo após o evento, "a mesma estrutura de poder que explora e oprime vocês, explora e oprime a nós". 354

351 Acerca da atuação política e intelectual de William F. Buckley e da constituição do movimento conservador norte-americano após a Segunda Guerra Mundial, cf. SOUSA, Rodrigo Farias de. $O$ nascimento do moderno conservadorismo nos Estados Unidos. Ideologia, liberalismo e raça na National Review, 1955-1968. Ed. Kindle. Rio de Janeiro, 2019.

${ }^{352}$ Ibidem, p. 202-207; CARMICHAEL, Stokely; THELWELL, Ekwueme M. op. cit., p. 588-589.

353 SEIDMAN, Sarah. op. cit., p. 1-2; 5.

${ }^{354} \mathrm{O}$ artigo El Tercer Mundo, Nuestro Mundo de autoria de Stokely Carmichael foi publicado na primeira edição (julho-agosto) da revista Tricontinental, importante periódico vinculado à OSPAAAL Organização de Solidariedade com os Povos de África, Ásia e América Latina, organização fundadora do tricontinentalismo cubano. Considerada por Carmichael uma "bíblia nos círculos revolucionários", a revista propunha-se, segundo seu primeiro editorial, a constituir uma "tribuna de ideias", um fórum 
"Nós compartilhamos com vocês uma luta comum, está cada vez mais claro; temos um inimigo comum. Nosso inimigo é a sociedade branca imperialista ocidental. Nossa luta é para derrubar esse sistema que se alimenta e se expande através da exploração econômica e cultural de povos não-brancos, não-ocidentais do Terceiro Mundo. Compartilhamos com vocês também uma visão comum do estabelecimento de sociedades humanistas no lugar daquelas atualmente existentes. Procuramos, com vocês, mudar as bases de poder do mundo: a humanidade compartilhará os recursos de suas nações em vez de ter que entregá-los a saqueadores estrangeiros; as civilizações serão capazes de reter sua soberania cultural ao invés de serem forçadas a se submeterem aos governantes estrangeiros, que impõem suas próprias culturas corruptas nas civilizações que dominam. $^{355}$

Em outras palavras, o lugar do movimento Black Power era ao lado de todos aqueles que se sublevavam contra o poderio norte-americano e europeu no chamado Terceiro Mundo. No entanto, ao passo que destacava a busca por integrar a luta negra aos movimentos terceiromundistas como um todo, em Havana, a fala de Carmichael almejava, também, delimitar laços e solidariedades mais específicas, em particular com as forças progressistas latino-americanas. Dessa forma, enquanto nos discursos antibelicistas anteriores o ativista construíra aproximações entre as resistências negra e vietnamita, durante a OLAS, ele vinculou a luta do Black Power contra o "colonialismo interno" ao anti-imperialismo dos povos hispânicos no continente. Aludindo ao apoio dado pelo SNCC ao movimento de independência nacional em Porto Rico (território até hoje sob tutela dos Estados Unidos), Carmichael defendeu que havia, entre ambas as partes, uma comunhão de interesses e objetivos fundamentada na experiência compartilhada da

político e cultural de intelectuais e líderes terceiro-mundistas destinado à "agitação, difusão e intercâmbio das experiências revolucionárias" voltadas à "plena liberdade da humanidade". De maneira geral, o artigo de Carmichael na revista reproduzia e sintetizava os principais pontos levantados pelo ativista em seu discurso durante a conferência da OLAS incluído em Stokely Speaks e discutido aqui nessa seção. CARMICHAEL, Stokely. El Tercer Mundo, Nuestro Mundo. Tricontinental, v. 01, n. 01, jul. - ago. 1967, p. 17; GENEROSO, Lidia Maria de Abreu. op. cit., p. 57-59 e SEIDMAN, Sarah. op. cit., p. 3.

355 "We share with you a common struggle, it becomes increasingly clear; we have a common enemy. Our enemy is white Western imperialist society. Our struggle is to overthrow this system that feeds itself and expands itself through the economic and cultural exploitation of non-white, non-Western peoples - of the Third World. We share with you also a common vision of the establishment of humanistic societies in the place of those now existing. We seek, with you to change the power bases of the world - mankind will share the resources of their nations instead of having to give them up to foreign plunderers; civilizations will be able to retain their cultural sovereignity instead of being forced to submit to foreign rulers, who impose their own corrupt cultures on those civilizations they would dominate". CARMICHAEL, Stokely. Solidarity with Latin America. In: . Stokely Speaks: From Black Power to Pan-Africanism. 2. ed. Lawrence Hill Books, 2007, p. 101-102. Itálicos nossos. 
opressão. Em última instância, isso implicava que os negros se identificassem com as causas dos “camaradas" latino-americanos, reconhecendo-se, nas palavras dele, "não como afro-americanos dos Estados Unidos, mas como afro-americanos das Américas". 356

"Nosso destino não pode ser separado do destino dos povos de língua espanhola nos Estados Unidos e nas Américas. Nossa vitória não será alcançada a menos que eles celebrem sua libertação lado a lado conosco. Pois não é a luta deles, mas a nossa luta juntos. Já nos comprometemos a fazer o que nos é pedido para ajudar na luta pela independência de Porto Rico, para libertá-la da dominação dos negócios e interesses militares dos Estados Unidos; e olhamos para Cuba como um exemplo reluzente de esperança em nosso hemisfério. Não vemos nossa luta contida dentro dos limites dos Estados Unidos como estão definidos nos mapas atuais - em vez disso, olhamos para o dia em que os verdadeiros Estados Unidos da América se estenderão da Terra do Fogo ao Alasca, quando aqueles outrora oprimidos estarão juntos, um povo liberto". 357

No entanto, é importante notarmos que, convergências à parte, Carmichael e a liderança cubana divergiam quanto a ênfase dedicada à pauta antirracista nos processos revolucionários. Discursando durante o evento, Fidel Castro defendeu que o racismo tinha sua origem na “exploração e opressão" capitalista, não constituindo, portanto, um problema propriamente "racial" e sim um "problema de classe". ${ }^{358}$ Esse enfoque, pautado pela ênfase na ortodoxia marxista-leninista a qual o líder cubano havia se filiado publicamente desde o seu célebre discurso De Martí a Marx de 1961, contrastava-se à caracterização que Carmichael fazia do racismo como uma categoria à parte, um fenômeno que, uma vez vinculado à singularidade da experiência histórica negra no Atlântico, demandava atenção e uma agenda específicas. ${ }^{359}$

\footnotetext{
${ }^{356}$ Ibidem, p. 104.

357 "Our destiny cannot be separated from the destiny of the Spanish-speaking people in the United States and of the Americas. Our victory will not be achieved unless they celebrate their liberation side by side with us. For it is not their struggle, but our struggle together. We have already pledged ourselves to do what we are asked to do to aid the struggle for the independence of Puerto Rico, to free it from domination by U.S. business an military interests; and we look upon Cuba as a shinning example of hope in our hemisphere. We do not view our struggle as being contained within the boundaries of the United States as they are defined in present-day maps - instead, we look to the day when a true United States of America will extend from Tierra del Fuego to Alaska, when those formerly oppressed will stand together, a liberated people". Ibidem, p. 105. Itálicos nossos.

${ }^{358}$ SEIDMAN, Sarah. op. cit., p. 8-9.

359 Pronunciado em 02 de dezembro de 1961, o discurso De Martí a Marx representa um marco central da Revolução Cubana: pela primeira vez, Fidel Castro declarou o alinhamento ideológico do regime cubano ao marxismo-leninismo, ancorando firmemente a luta anti-imperialista do país caribenho dentro do campo socialista. Cf. CASTRO, Fidel. De Martí a Marx. In: LÖWY, Michael (org.). O Marxismo na América
} 
Conforme expresso em sua fala, Stokely distinguia-se da perspectiva castrista ao defender a luta conjunta, simultânea, contra o racismo e o capitalismo pelo viés da autodeterminação e solidariedade racial entre os negros e demais povos "não-brancos". Com isso, ao reiterar - como fizera anteriormente em Londres - que "cor e cultura foram, e ainda são, centrais em nossa opressão", o ativista mantinha-se firmemente ancorado no nacionalismo negro do Black Power sem, contudo, negar o viés anticapitalista compartilhado com o regime cubano. ${ }^{360}$

"Já que nossa cor tem sido usada como arma para nos oprimir, devemos usá-la como arma de libertação, assim como outros povos usam sua nacionalidade como arma para libertação. O Black Power entende que somos forçados a nos sentirmos inferiores para sermos mais facilmente explorados. Mas mesmo que destruíssemos o racismo, não acabaríamos necessariamente com a exploração; e se destruíssemos a exploração, não acabaríamos necessariamente com o racismo. Ambos devem ser destruídos; devemos constantemente lançar um ataque em duas vertentes; devemos constantemente manter nossos olhos em ambos os chifres da besta". 361

Portanto, não obstante as solidariedades estabelecidas entre Carmichael, Castro e o regime cubano, tais divergências programáticas impunham limites à criação de uma aliança formal entre o militante do Black Power e a Revolução Cubana. Em última instância, à medida que se tornavam claros os distintos lugares ocupados por cada movimento, a aproximação entre ambas as lideranças consolidou-se mais em termos pessoais do que, de fato, institucionais. ${ }^{362}$ Ainda assim, segundo lembraria tempos depois, a experiência em Cuba deixara uma profunda impressão em Carmichael ao conferir uma "face humana" às agendas terceiro-mundistas e revolucionárias

Latina: uma antologia de 1909 aos dias atuais. São Paulo: Fundação Perseu Abramo, 1999, p. 273.

${ }^{360}$ CARMICHAEL, Stokely. The Dialectics of Liberation. In: ___. op. cit., p. 87. Formulada pelo ativista pela primeira vez nos discursos de Londres e Havana, a defesa de uma luta negra conjunta contra os males do racismo e capitalismo tornou-se um dos principais - e mais recorrentes - pontos do projeto transnacional que o ativista imprimia ao movimento Black Power e, depois, à agenda pan-africanista. Esta temática, portanto, repetiu-se por diversas vezes em seus discursos posteriores. A esse respeito, cf. CARMICHAEL, Stokely. op. cit., 2007, p. 121-122; 133-134; 192-195.

361 "Because our color has been used as a weapon to oppress us, we must use our color as a weapon for liberation, just as other people use their nationality as a weapon for their liberation. Black Power recognized that we are made to feel inferior so that we may be more easily exploited. But even if we destroyed racism, we would bot necessarily destroy exploitation; and if we destroyed exploitation, we would not necessarily destroy racism. They must both be destroyed; we must constantly launch a twopronged attack; we must constantly keep our eyes on both of the bull's horns". CARMICHAEL, Stokely. op. cit., 2007, p. 107. Itálicos nossos.

${ }^{362}$ SEIDMAN, Sarah. op. cit., p. 14. 
as quais ele conectava o Movimento Black Power: "Para mim, a luta internacional tornou-se tangível, uma realidade humana, nomes rostos, histórias, não eram mais uma abstração. E nossa luta no Mississippi ou no Harlem era parte integrante desse grande movimento internacional e histórico". 363

Ao final da conferência, Stokely deu prosseguimento às suas viagens e partiu de Havana a bordo do mesmo vôo para Minsk no qual voltava a delegação soviética presente na OLAS. Nas semanas seguintes, entre inesperados encontros em Beijing com Robert F. Williams e Shirley Graham DuBois - intelectual negra e viúva de W.E.B. DuBois - e uma breve estadia em Hanoi onde foi recebido por Ho Chi Minh e por representantes da FNL vietnamita, o ativista embarcou para a África, continente que, nos anos seguintes, ocuparia o centro das suas preocupações políticas para a luta negra.

\subsubsection{Argélia e Guiné: "cooperação afro-árabe” e primeiras sociabilidades pan- africanistas}

"Eu tenho dois sonhos em minha vida. Meus sonhos estão enraizados na realidade e não em abstrações [imagery]. Sonho, número um, em tomar café com minha esposa na África do Sul; e, número dois, em tomar chá de menta na Palestina". 364

Viajando pela África, Stokely Carmichael seguiu os passos dados por Malcolm X e por tantos outros ativistas e intelectuais afro-americanos que, em passagens pelo continente e por regiões do Oriente Médio, encontraram abrigo temporário ou permanente em nações africanas e árabes recém-independentes. No decorrer da década de 1960, os laços entre a militância negra dos Estados Unidos e os movimentos de libertação do continente se estreitavam: antes de Stokely, Malcolm X e uma delegação do SNCC já haviam visitado Conacri, capital da Guiné, sendo recebidos pelo presidente Sékou Touré. Na cidade de Acra, em Gana, Shirley e W.E.B. Du Bois, a poetisa Maya Angelou, o ator e escritor Julian Mayfield, dentre outros, formaram uma

\footnotetext{
363 "For me, the international struggle became tangible, a human reality, names, faces, stories, no longer an abstraction. And our struggle in Mississippi or Harlem was part and parcel of this great international and historical motion. It was both humbling and inspiring. I felt recommitted, energized". CARMICHAEL, Stokely; THELWELL, Ekwueme M. op. cit., p. 584.

364 "Now, there are two dreams I have in my life. My dreams are rooted in reality, not in imagery. I dream, number one, of having coffee with my wife in South Africa; and number two, of having mint tea in Palestine". CARMICHAEL, Stokely. The Black American and Palestinian Revolutions. In: Stokely Speaks: From Black Power to Pan-Africanism. 2. ed. Lawrence Hill Books, 2007, p. 143.
} 
pequena porém influente comunidade de expatriados afro-americanos sob os auspícios de Kwame Nkrumah. Na Argélia, país adotivo de Frantz Fanon e símbolo da luta anticolonial do período, os panteras negras Eldridge Cleaver e Kathleen Cleaver estabeleceriam uma “embaixada" do Partido a convite do presidente Houari Boumédiène. Portanto, na esteira dessas e outras sociabilidades pan-africanistas, Carmichael seguiu para a Argélia e a Guiné, onde solidarizou-se com os povos árabes do Norte e Noroeste africanos e adentrou os circuitos intelectuais e políticos pan-africanos que historicamente aproximavam os negros dos dois lados do Atlântico. ${ }^{365}$

Uma vez na Argélia, Carmichael estendeu suas críticas anti-imperialistas ao Estado de Israel. Em setembro de 1967, na esteira das polêmicas em torno da Guerra dos Seis Dias ocorrida pouco antes entre 5 e 10 de junho daquele ano, o ativista ganhou manchetes locais e internacionais ao denunciar veementemente a política externa israelense no Oriente Médio e no Norte da África. Para a satisfação dos seus anfitriões do Front de Libération Nationale, partido revolucionário argelino que, anos antes, vencera a guerra de independência contra a França (1954-1962), Stokely caracterizou o sionismo como um movimento racista movido por ambições imperialistas sobre o território da Palestina e posicionou-se firmemente em favor do lado árabe no conflito representado pela OLP - Organização para a Libertação da Palestina. ${ }^{366}$ Com isso, ele visava conectar a busca por autodeterminação negra nos Estados Unidos às aspirações nacionalistas árabes pela retomada da soberania nas regiões de Gaza, na Península do Sinai, Cisjordânia e nas Colinas de Golã recentemente ocupadas pela ofensiva israelense. ${ }^{367}$

\footnotetext{
${ }^{365}$ Sobre os trânsitos de intelectuais e ativistas afro-americanos pela África independente, cf. CARSON, Clayborne. op. cit., p. 134-136; MARABLE, Manning, op. cit., 2013, p. 352; BLOOM, Joshua; MARTIN Jr., Waldo E. op. cit., p. 314-322.

366 JOSEPH, Stokely. op. cit., 2014, p. 215-217; CARMICHAEL, Stokely; THELWELL, Ekwueme M. op. cit., p. 557-563.

${ }^{367}$ Envolvendo os países fronteiriços de Israel, Síria, Egito e Jordânia, a Guerra dos Seis Diais iniciou-se com um ataque israelense surpresa à força aérea egípcia seguido de uma rápida vitória sobre os efetivos sírios e jordanianos. Devido às hostilidades há décadas latentes no Oriente Médio e suas repercussões para a geopolítica da região, o conflito é atravessado por um forte "choque de narrativas". Do lado de Israel, alegou-se que a investida militar tinha um caráter supostamente "preventivo" contra um possível ataque dos países árabes e, do lado árabe, denunciaram-se as motivações expansionistas israelenses. As consequências da guerra perduram até hoje: com a vitória, Israel aumentou em três vezes e meia o seu território, devastando as forças militares dos seus vizinhos e as aspirações pan-arabistas de Gamal Abdel Nasser, presidente do Egito. Por sua vez, à derrota árabe seguiu-se o aumento do número de refugiados e o fortalecimento do nacionalismo palestino debilitado desde a $N a k b a$, o êxodo populacional maciço em decorrência dos conflitos durante a criação do Estado de Israel em 1948. Nas décadas seguintes, Israel e a OLP, liderada por Yasser Arafat, intensificariam ações e retaliações armadas entre si. Sobre o tema, cf. SUNDQUIST, Eric J. Strangers in the Land. Blacks, Jews, Post-Holocaust America. Cambridge: Harvard University Press, 2008, p. 319-330 e SAID, Edward. A Questão Palestina. Ed. Unesp, 2012.
} 
"Não nos importamos com o que o Departamento de Estado [norteamericano] diz, não nos importamos com o que a CIA diz, não nos importamos com o que Lyndon Baynes Johnson diz. Desde que tenhamos pernas, eles não podem nos impedir de ir para a Argélia. Eles não podem nos impedir de ir para a República Árabe Unida [atual Egito]. Eles não podem nos impedir de ir para a Síria. Contanto que vocês nos convidem, nós [afro-americanos] viremos". 368

Como vimos, aos poucos, Stokely Carmichael ampliava o foco de ação política do Black Power, deixando as fronteiras nacionais, vinculando a causa negra às ações contestatórias e radicais por onde passava: Londres, Cuba e, agora, Argélia. Nas cidades de Argel e Orã, as primeiras declarações de Carmichael em prol da luta palestina representavam uma inflexão significativa em relação às visões pró-Israel do ativista durante sua adolescência em meio à intelectualidade judaica de esquerda na Bronx High School of Science. Em finais da década de 1960, tal reviravolta acompanhava o posicionamento antissionista que se difundia entre radicais do Black Power, levando-os a romper laços com judeus liberais aliados das lutas anteriores por Direitos Civis. ${ }^{369}$ Naquele momento, atentos às ocupações israelenses e ao drama dos refugiados palestinos e sírios oriundos da Guerra dos Seis Dias, muitos dentro do SNCC, do Partido dos Panteras Negras e das esquerdas terceiro-mundistas do período passaram a enxergar os judeus não mais como vítimas históricas da opressão, mas, desta vez, como algozes dos povos árabes com o apoio norte-americano. Isto é, para Carmichael e tantos outros, Israel agia como uma potência "colonial" contra a qual deveriam se opor os "colonizados" do Oriente Médio e, também, das Américas. ${ }^{370}$

368 "We don't care what the State Department says, we don't care what the CIA says, we don't care what Lyndon Baynes Johnson says, as long as we have legs they cannot stop us from going to Algeria. They cannot stop us from going to the United Arab Republic. They cannot stop us from going to Syria. As long as you invite us we will come". CARMICHAEL, Stokely. The Black American and Palestinian Revolutions. In: op. cit., 2007, p. 143.

369 É importante destacarmos que, de maneira geral, lideranças negras liberais e mais moderadas como Bayard Rustin e Roy Wilkins (NAACP) mantiveram-se alinhadas politicamente com Israel. Conquanto à época intensificasse suas perspectivas anti-imperialistas, Martin Luther King também posicionou-se favoravelmente ao Estado israelense. SUNDQUIST, Eric J. op. cit., p. 331.

${ }^{370}$ No entanto, ao passo que, na década de 1960, os laços que anteriormente aproximaram as comunidades judaica e negra se deterioravam, o chamado do Black Power à autoafirmação e orgulho identitário influenciava outros grupos, como os judeus, nos Estados Unidos. Segundo destaca Gary Gerstle, inspirados pelos nacionalistas negros, muitos deles tornaram-se mais confiantes em demonstrar sua religiosidade e cultura em público, recorrendo ao uso de ornamentos típicos como o quipá e a adoção de nomes bíblicos. GERSTLE, Gary. op. cit., p. 331-333; Sobre o posicionamento do SNCC, cf. CARSON, Clayborne. op. cit., p. 267-269; SUNDQUIST, Eric J. op. cit., p. 337. 
De imediato, esse posicionamento fomentou fortes antagonismos políticos entre as comunidades afro-americana e judaica nos Estados Unidos. Alegações posteriores de Carmichael de que "os mesmos sionistas que exploram os árabes também nos exploram neste país" provaram-se muito controversas, rendendo acusações de antissemitismo ao ativista e à militância do Black Power que se aliava à causa palestina. ${ }^{371}$ Estes últimos, por sua vez, respondiam aos seus detratores sionistas denunciando as violações contra os direitos dos palestinos e os laços comerciais e militares estabelecidos por Israel com o regime racista do apartheid na África do Sul. Não por acaso, portanto, dentre as pautas terceiro-mundistas endossadas por Carmichael, o antissionismo tornou-se motivo de uma virulenta e duradoura contenda a ponto de, décadas depois, ele precisar explicar-se em suas memórias: "Então eu posso dizer ao mundo: eu não sou agora, nunca fui e nunca serei antissemita ou antijudaico. No entanto, eu sou e serei antissionista até a morte". 372

De toda forma, a despeito das polêmicas iniciadas em Argel, o ativista permanecera um opositor convicto do Estado de Israel. Em agosto de 1968, na cidade de Ann Arbor (Michigan), berço da SDS, Carmichael fez seu principal discurso acerca do tema no qual classificou aquele país como "injusto" e "imoral", alegando que ele representava uma instância do imperialismo norte-americano, isto é, "nada além de um dedo dos Estados Unidos [na região]". 373 Naquela ocasião, perante uma convenção de estudantes árabes da University of Michigan, Stokely chamou as forças árabes de "camaradas de armas" e enalteceu o exemplo de Fatima Bernawi, guerrilheira afro-palestina vinculada ao Al Fatah - facção da OLP fundada por Yasser Arafat - presa por uma tentativa de atentado a bomba em Jerusalém no ano anterior. Recomendando aos presentes que seguissem o exemplo de "lady" Fatima, Carmichael reiterava sua visão de que, frente as ameaças impostas por "agentes externos", isto é, pelas forças norte-americanas e israelenses que ocupavam os guetos negros e os países muçulmanos, afro-americanos e árabes dispunham de uma única saída possível: a luta armada. ${ }^{374} \mathrm{Ou}$ seja, conforme o ambiente político no Oriente

${ }^{371}$ CARMICHAEL, Stokely. The Black American and Palestinian Revolutions. In: op. cit., 2007, p. 138.

${ }^{372}$ CARMICHAEL, Stokely; THELWELL, Ekwueme M. op. cit., p. 563.

373 Para além do discurso The Black American and Palestinian Revolutions aqui discutido, o ativista mencionaria brevemente a pauta antissionista em outras ocasiões, particularmente nos discursos Free Huey e A New World to Build compilados em Stokely Speaks. CARMICHAEL, Stokely. The Black American and Palestinian Revolutions. In: 122-123; 161-162.

${ }^{374}$ Ibidem, p. 142 op. cit., 2007, p. 137; 142. Cf., também, Ibidem, p. 
Médio se radicalizava, Stokely acompanhava essa direção.

“Agora, nossa posição é clara: a autodefesa somente manterá o status quo. Se o Egito, a Síria e a Jordânia assumissem uma posição de autodefesa hoje, eles sairiam perdendo porque os israelenses ainda ocupam o território. Se eles quiserem o território de volta, eles devem se mover agressivamente contra as forças de ocupação. E à medida que eles se movem agressivamente, nós [afro-americanos] temos que nos movimentar agressivamente. Não há necessidade de falar em coexistência pacífica; qualquer um que clame por coexistência pacífica está pedindo que o status quo permaneça do jeito que é. A única solução é a revolução armada!". 375

Assim, por um lado, à semelhança do observado anterioremente em Cuba, as solidariedades políticas que Carmichael buscava firmar na África do Norte e no Oriente Médio calcavam-se na ideia de que as populações árabes e afro-americanas partilhavam de objetivos, lutas e interesses comuns. Para ambos, defendia o ativista, a plena libertação somente seria alcançada através da destruição das formas racistas e coloniais de opressão produzidas pelo Ocidente capitalista no Terceiro Mundo. Sob essa ótica, na fala de Stokely, o Black Power e o nacionalismo palestino constituíam facetas distintas de uma mesma e inexorável luta pela humanidade há muito negada aos oprimidos: "o mundo da humanidade agora dá voltas; os oprimidos estão começando a sentir sua força. Estamos começando a sentir nosso poder. É na nossa unidade que vamos encontrar a vitória [...]; as contradições, como eu disse antes, forçarão essa unidade". 376

No entanto, a Guerra dos Seis Dias comportava, ainda, uma outra especificidade a partir da qual Carmichael e a militância afro-americana teciam solidariedades com os povos do Oriente Médio. Em especial, os avanços militares israelenses sobre o Egito - "lar ancestral" da cultura e civilização negras caro ao imaginário nacionalista negro desde o século XIX - facilitaram a aproximação do Black Power e das lutas árabes-palestinas por meio da percepção de Israel como

\footnotetext{
375 "Now we stand clear - self-defense will only maintain the status quo. If Egypt, Syria, and Jordan took a position of self-defense today, they would come out losing because the Israelis still occupy the land. If they want the land back, they must move aggressively against the occupying forces. And as they move aggressively, we have to move aggressively. There is no need to talk about peaceful coexistence; anyone who calls for peaceful co-existence is calling for the status quo to remain the way it is. The only solution is armed revolution!"’. Ibidem, p. 139.

376 "The world of humanity now turns; the oppressed are beginning to feel their strength. We are begining to feel our power. It is in our unity that we will find victory [...]; the contradictions, as I said befor, will force that unity". Ibidem, p. 143.
} 
“inimigo comum" das nações e dos movimentos de libertação africanos. Como consequência, a resposta ao conflito reatou laços entre o nacionalismo árabe representado pelo presidente egípcio Gamal Abdel Nasser e as aspirações pan-africanistas em vigor dentro e fora do continente. À luz dessa "cooperação afro-árabe", a tomada dos territórios do Sinai e da Faixa de Gaza pelos israelenses traduzia-se, para Stokely e tantos outros, não somente em uma agressão a um aliado muçulmano "não-branco" e "não-ocidental”, mas também à África e aos negros da diáspora como um todo. ${ }^{377}$

“Quando a agressão [a Guerra dos Seis Dias] ocorreu em 1967, milhões de dólares foram arrecadados em toda a América com um estalar de dedos. Jovens judeus abandonaram os estudos para ir lutar pela pátria. Eles estabeleceram um Estado em 1948 e, mesmo assim, ainda sentem laços tão fortes com ele. Não há diferença em relação aos negros indo defender e lutar pelo Egito. O Egito está na África e a África é nossa pátria. A civilização mais antiga do mundo vem do Egito. Nós [afroamericanos] precisamos sentir que somos parte disso. [...] Nós pretendemos lutar contra o imperialismo onde quer que ele esteja, seja nos Estados Unidos ou em nossa pátria. Assim, dizemos muito claramente que, porque o Egito está em nossa pátria, lutaremos contra as forças do imperialismo sempre que elas estiverem tentando invadir nossa pátria, a nossa terra natal". 378

Em outras palavras, na fala de Carmichael, a fraternidade com os palestinos e a identificação com o Egito combinavam-se para ligar o Black Power às lutas por soberania nacional no continente, conexão esta viabilizada pela recuperação simbólica de uma "pátria africana", uma "terra natal" negra aviltada pela ação colonizadora israelense. ${ }^{379}$ Dessa forma, o trecho acima dimensiona a importância crescente que Stokely passava a atribuir à África em seu programa político-identitário durante e após suas viagens pelos países do continente. Se nos

${ }^{377}$ MAZRUI, Ali A. (ed.). História Geral da África, VIII: África desde 1935. São Paulo: Cortez Editora, 2011, p. 917-921 e SUNDQUIST, Eric J. op. cit., p. 330-336.

378 "When the aggression took place in 1967, millions of dollars were raised across America at the snap of a finger. Young Jewish people were dropping out of school to go and fight for the homeland. They established a state in 1948 and yet they feel such a strong tie with it. There is no difference in black people going to fight for and defend Egypt. Egypt is in Africa and Africa is our homeland. The oldest civilization in the world comes from Egypt. We must feel we are a part of it. [...] We intend to fight imperialism wherever it is, in the United States or in our homeland. So we say very clearly that because Egypt is in our homeland, we will fight those forces of imperialism whenever they are trying to invade our homeland, and our motherland". CARMICHAEL, Stokely. The Black American and Palestinian Revolutions. In: op. cit., 2007, p. 141. Itálicos nossos.

${ }^{379}$ SUNDQUIST, Eric J. op. cit., p. 334. 
Estados Unidos, como vimos nas análises do livro Black Power e dos primeiros artigos do ativista, Carmichael retirava da experiência colonial africana a inspiração para o diagnóstico do movimento afro-americano; a partir de então, nos artigos e discursos de finais da década, a libertação da África assumiu o centro das suas preocupações, tornando-se o locus privilegiado da luta negra no Atlântico.

Para tanto, a viagem do ativista à Guiné, pequeno país francófono da África Ocidental, desempenhou um papel crucial à inflexão do pensamento, da trajetória pessoal e da atuação política de Stokely Carmichael nos dois últimos anos da década de 1960. Entre setembro e outubro de 1967, após prolongada estadia na Argélia, o ativista chegou à cidade portuária de Conacri como um observador convidado do Oitavo Congresso do PDG - Partido Democrático da Guiné, partido do ex-sindicalista Sékou Touré que ascendera ao poder após a independência do país da Comunidade Francesa em 1958. No momento da visita de Carmichael, o governo autoritário comandado por Touré sobrevivia a duras penas aos avanços do neocolonialismo no continente. Um dos poucos representantes radicais do pan-africanismo remanescentes no poder, o regime guineense encontrava-se, à época, pressionado por golpes militares apoiados pela CIA e OTAN contra aliados importantes - no Congo (1962), em Gana (1966) e, pouco depois, no Mali (1968) - bem como pelo antagonismo de Estados vizinhos politicamente moderados e conservadores como a Costa do Marfim, Libéria e Senegal. ${ }^{380}$

Nesse cenário, a Guiné representava um país africano revolucionário que exercia grande apelo sobre Stokely, mas que abrigava um regime ditatorial acuado cuja manutenção ocorria às

${ }^{380}$ É importante fazermos a ressalva de que, nos anos 1960, o pan-africanismo não constituía uma corrente homogênea de pensamento e de proposições políticas partilhada por distintos Estados e lideranças africanas. Pelo contrário, os caminhos propostos para os países independentes eram diversos e frequentemente disputavam entre si, aglutinando-se em blocos que tendiam a posturas "pró-Ocidente" ou "pró-socialista". Em linhas gerais, em meio a uma série de conferências internacionais, duas vertentes pan-africanistas consolidaram-se no período: de um lado, Gana, Guiné, Mali, Marrocos, Líbia, Egito e a FLN argelina compunham o "Grupo de Casablanca" que endossava uma postura radical de união política continental, economia planificada e centralização administrativa de moldes socialistas, propondo até um mesmo sistema de defesa e um grande exército; por sua vez, Libéria, Senegal, Costa do Marfim, Nigéria, Serra Leoa, dentre outros, formaram o "Grupo de Monróvia", que caracterizou-se por propostas moderadas de cooperação inter-africana mais próximas do bloco capitalista e que não interferissem na soberania nacional e territorial dos Estados. A partir de 1963, essas tendências buscaram um consenso na formação da OUA - Organização da Unidade Africana (hoje União Africana). Contudo, a OUA inclinouse muito mais às propostas do Grupo de Monróvia do que àquelas defendidas pelo de Casablanca, evidenciando o enfraquecimento dos projetos radicais defendidos por Nkrumah e Touré nas relações internacionais africanas. PARADA, Mauricio et al. História da África Contemporânea. Rio de Janeiro: Ed. Puc-Rio: Pallas, 2013, p. 92-108 e MAZRUI, Ali A. (ed.). op. cit., p. 938; 976-982. 
custas da centralização política em torno de Touré e do PDG e de uma violenta repressão ao dissenso interno. Segundo pensavam Carmichael e parte das esquerdas dos anos 1960 e 1970, a instituição de governos democráticos liberais no "Terceiro Mundo" - política e economicamente fragilizado por obra das potências ocidentais - corria o risco de sujeitar as nações recémindependentes uma vez mais ao jugo do capital internacional e do imperialismo. Por isso, como vimos, o ativista e muitos outros radicais do período defendiam que a violência contra os oprimidos deveria ser combatida, também, pelo recurso à violência revolucionária - e, não raro, pela tomada do poder político por governos de partido único. Dessa forma, julgava-se então, as condições de opressão seriam eventualmente superadas pelos regimes revolucionários que se instalavam no lugar das forças colonialistas europeias. Por essas razões, lutas armadas e governos centralizadores como o cubano, chinês, vietnamita e alguns movimentos de libertação africanos constituíam referências políticas centrais para Stokely e parte das esquerdas do período.

Durante sua permanência em Conacri, Carmichael envolveu-se com Miriam Makeba, célebre cantora sul-africana e ativista anti-apartheid com a qual viria a se casar poucos meses depois, e encontrou-se regularmente com o ganês Kwame Nkrumah para discussões acerca do Black Power, dos movimentos de libertação no Terceiro Mundo e das revoluções africanas. ${ }^{381}$ Exilado em decorrência de sua deposição da presidência em Gana, Nkrumah, principal aliado de Touré acolhido no país sob o título honorário de co-presidente, passou a exercer influência direta nas perspectivas defendidas por Stokely. Líder veterano, o ganês possuía uma destacada atuação política transnacional e era um intelectual prolífico - autor de numerosos livros, dentre os quais, os clássicos Africa Must Unite (1963), Neocolonialism: the last stage of imperialism (1965) e Consciencism: Philosophy and ideology for decolonization (publicado pela primeira vez em 1964 e revisado em 1970) - reconhecido internacionalmente pela sua denúncia ferrenha do neocolonialismo e pelo papel central que desempenhara na articulação do pan-africanismo no contexto das independências africanas após a Segunda Guerra Mundial. ${ }^{382}$ Não por acaso, Carmichael ansiava por conhecê-lo.

A trajetória e o pensamento de Nkrumah confundem-se com a institucionalização do

\footnotetext{
${ }^{381}$ CARMICHAEL, Stokely; THELWELL, Ekwueme M. op. cit., p. 615-617.

382 SCHERER, Mathias Inacio. Kwame Nkrumah, o neocolonialismo e o pan-africanismo. In: MACEDO, José Rivair (org.). O Pensamento Africano no Século XX. São Paulo: Outras Expressões, 2016, p. 143-144 e CARMICHAEL, Stokely; THELWELL, Ekwueme M. op. cit., p. 595; 617.
} 
movimento pan-africanista e o fortalecimento das lutas antirracistas dentro e fora da África. ${ }^{383}$ Formado em Filosofia e Teologia - com mestrados em Educação e Filosofia - pelas universidades norte-americanas da Pennsylvania e Lincoln University, nos anos 1940, o ganês integrou um vibrante círculo de intelectuais negros sediados em Londres que incluíam os futuros presidentes do Quênia e da Nigéria, Jomo Kenyatta e Nnamdi Azikiwe; os caribenhos C.L.R. James e George Padmore; e o afro-americano Richard Wright. Na Inglaterra, associou-se a Padmore e a W.E.B. Dubois para organizar o V Congresso Pan-Africano de Manchester, ponto de virada do pan-africanismo mencionado no primeiro capítulo. De volta à sua terra natal, Nkrumah consolidou uma base popular de apoio para fundar o CPP - Convention People's Party, partido de orientação socialista com o qual venceu as eleições parlamentares de 1951 e lançou uma campanha de desobediência civil decisiva para a conquista da independência junto aos britânicos. Assim, em 1957, a Costa do Ouro tornou-se Gana, o primeiro país independente na África Subsaariana - a chamada "África Negra" - projetando Nkrumah como uma das principais lideranças anticoloniais do continente. ${ }^{384}$

Produto da mobilização política de distintas gerações de negros do continente e, também, da diáspora, a ascensão pioneira de Nkrumah à presidência de um país africano emancipado alimentou novos processos de independência na África - em 1960, no chamado "ano africano", dezessete novos Estados alcançaram a independência -, bem como impactou profundamente as lutas negras nos Estados Unidos e no Caribe. Na época, as afirmações de Nkrumah de que havia "um novo Africano no mundo" pronto para mostrar que "o homem negro é capaz de cuidar dos próprios assuntos" ecoaram fortemente entre o movimento afro-americano, inspirando as lutas por Direitos Civis e os "sonhos" de nacionalistas negros da diáspora que almejavam fundar nações independentes no continente. ${ }^{385}$

383 Para uma discussão detalhada das complexidades do movimento pan-africanista, sua trajetória transnacional, desenvolvimento histórico e pluralidade de agendas dentre as quais figuravam as proposições de Nkrumah, cf. HERNANDES, Leila Leite. A África na sala de aula. Visita à História Contemporânea. 2a edição revista. São Paulo: Selo Negro, 2008, p. 136-155; 193-199.

${ }^{384}$ Sobre a biografia e o pensamento de Nkrumah, cf. BINEY, Ama. The political and social thought of Kwame Nkrumah. New York: Palgrave MacMillan, 2011. A esse respeito, ver, também, o artigo de Alexandre Marcussi acerca da obra Consciencism em MARCUSSI, Alexandre Almeida. Personalidade, raça e nação na África pós-colonial: alguns apontamentos a partir das ideias de Kwame Nkrumah. In: REIS, Raissa Brescia et al (orgs.). Estudos sobre África Ocidental: dinâmicas culturais, diálogos atlânticos. Curitiba: Editora Prismas, 2016, p. 259-285.

${ }^{385}$ Não por acaso, portanto, as celebrações da independência de Gana contaram com a presença de uma importante delegação de ativistas e intelectuais negros dos Estados Unidos como A. Philip Randolph, 
Contudo, o projeto de Nkrumah para a África não se restringia à defesa da autonomia administrativa das colônias, mas era compreendido dentro de um processo mais amplo de emancipação do jugo colonial e do capital estrangeiro através da unificação continental segundo marcos socialistas próprios. Tendo participado da Conferência de Bandung em 1955, ele concebia a libertação nacional, portanto, como uma primeira e necessária etapa da busca pelo desenvolvimento econômico e autodeterminação política dos povos africanos frente às mais distintas e predatórias formas neocoloniais de ingerência externa. ${ }^{386}$ Segundo ele, para que a África atingisse seu pleno potencial, a conquista do "reino político" precisaria ser acompanhada de um projeto de centralização governamental e planificação econômica em escala continental. Cerne do projeto político pan-africanista de Nkrumah ao qual Carmichael se vinculou, tais perspectivas moldavam o lema do CPP - "primeiro a liberdade" - e a fala do líder ganês durante as celebrações da independência de Gana: "Nós lutamos a batalha e, novamente, nos voltamos não só às lutas para emancipar outros países da África - a nossa independência não tem sentido a não ser que esteja ligada à libertação total do continente africano". ${ }^{387}$

Adam Clayton Powell, Ralph Bunche e Martin Luther King. Ademais, nos anos seguintes, W.E.B. Du Bois se mudou para Acra e Malcolm X também visitou o país. Cf. BINEY, Ama. op. cit., p. 77-79 e KING JR., Martin Luther; CARSON, Clayborne (org.). A autobiografia de Martin Luther King. Rio de Janeiro: Zahar, 2014, p. 139-144.

${ }^{386}$ Teorizado no livro Neocolonialism: the last stage of imperialism (1965), o conceito de neocolonialismo era central às reflexões e pretensões políticas do líder ganês. Em linhas gerais, o neocolonialismo constituía, como indicado pelo título da obra, o "último estágio do imperialismo", isto é, a reconfiguração do imperialismo perante o cenário no qual os processos de independência africanos generalizavam-se e a manutenção do jugo europeu nos moldes coloniais anteriores não era mais possível. Porém, segundo Nkrumah, era justamente nessa aparência de mudança no jogo de forças que residia o perigo: mesmo com a autonomia nominal, a soberania nacional dos Estados africanos permanecia no plano simbólico. Econômica e politicamente, os países independentes ainda se encontravam sob o controle do capital industrial e financeiro externo que os submetia - à força, se necessário - a acordos comerciais altamente desfavoráveis, taxas de juros e empréstimos abusivos, dívidas exponenciais, intervenções agressivas, em suma, à condição de um "novo imperialismo". SCHERER, Mathias Inacio. op. cit., p. 148-155.

${ }^{387}$ BINEY, Ama. op. cit., p. 78. Acerca do projeto pan-africanista de Nkrumah, cf., também, MALACCO, Felipe Silveira de Oliveira. Unidade Nacional e Unidade Continental: uma discussão acerca dos projetos políticos de Amílcar Cabral e Kwame Nkrumah. Revista Ars Histórica, n. 17, jul./dez. 2018, p. 88-93. Itálicos nossos. 


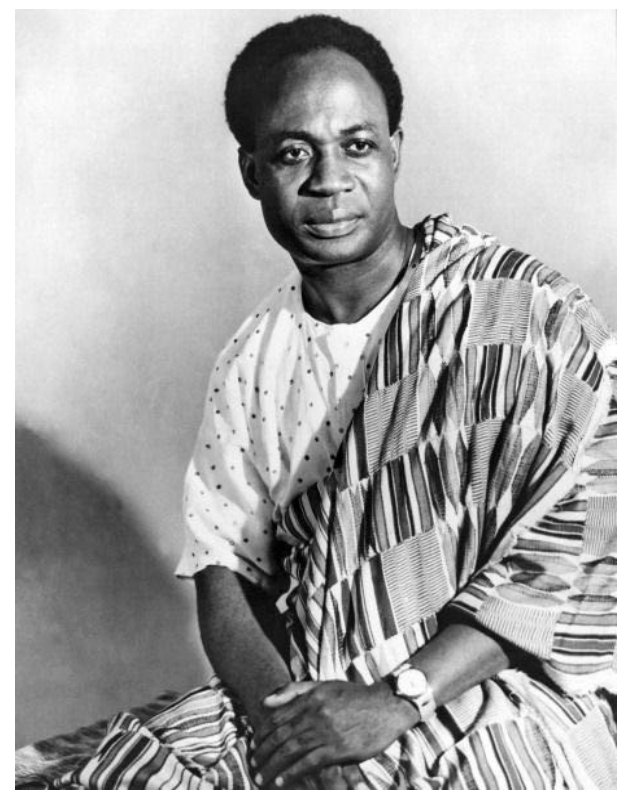

Imagem 11 - Kwame Nkrumah, presidente e líder da independência de Gana exilado na Guiné após sua destituição por um golpe militar em 1966. Propositor de um pan-africanismo continental de cunho socialista, Nkrumah tornou-se mentor político de Carmichael após este conhecê-lo em Conacri. Fonte: Getty Images. Disponível em: <https://www.gettyimages.com/detail/news-photo/dr-kwame-nkrumah-ofnewly-independent-ghana-ghana-mid-to-news-photo/146126958>. Acesso em: 10 de março de 2019.

Em suma, tendo circulado pelos Estados Unidos, Europa e África, o ex-presidente ganês fazia parte de uma extensa rede de intelectuais e políticos do Atlântico Negro que, durante a primeira parte do século XX, propuseram-se a organizar a resistência ao colonialismo europeu, lançando as bases para os movimentos de independência e as iniciativas em prol da unidade africana dos anos 1950 e $1960 .{ }^{388}$ Por essa razão, os encontros de Carmichael com o veterano Nkrumah em Conacri impactaram profundamente o jovem militante, introduzindo-lhe às sociabilidades, redes e disputas políticas pan-africanas em construção desde, pelo menos, o mencionado V Congresso de Manchester. A partir de então, sob orientação direta do Osagyefo epíteto de louvor atribuído a Nkrumah que significava "redentor" da nação - Stokely convenciase de que havia uma linha de continuidade necessária entre o movimento Black Power, a libertação e unificação da África. A convite do ganês, como veremos na seção seguinte, a busca pela articulação dessas duas frentes da luta negra tornou-se o trabalho da vida de Carmichael:

"Talvez a primeira coisa significativa que Osagyefo me disse - em nossa primeira reunião - foi sobre consciência e a unidade de nossas lutas. Quer soubéssemos ou não, disse ele, a luta afro-americana está

${ }^{388}$ SCHERER, Mathias Inacio. op. cit., p. 144-146. 
inextricavelmente ligada à luta na África e vice-e-versa. Aqueles de nós que estivessem conscientes disso tinham a responsabilidade de tornar a conexão clara para aqueles que não se dessem conta disso. A melhor arma do inimigo, ele disse, era a falta de consciência entre o nosso povo". 389

Por fim, em dezembro de 1967, Carmichael encerrou seu tour internacional e retornou aos Estados Unidos após escalas na Tanzânia, breves passagens por países escandinavos e uma estadia em Paris. Nesse intervalo, como vimos, as constantes viagens foram decisivas para consolidar, no pensamento do ativista, um diagnóstico e um programa político transnacionais do qual os afro-americanos eram parte integrante. À luz desta clivagem em suas perspectivas, a identidade - ou melhor, o processo de identificação - de Carmichael também deslocava-se do seu eixo mais propriamente afro-americano e "nacional" para um referencial terceiro-mundista: articulando o Black Power às pautas anti-imperialistas, anticapitalistas e anticoloniais do período, Stokely passara a conceber os negros norte-americanos como parte de uma extensa comunidade transnacional dentro da qual solidariedades políticas e sociabilidades intelectuais revolucionárias uniam os "condenados da terra". Após viajar pela Guiné, contudo, essas perspectivas ganharam contornos ainda mais específicos, afrocêntricos, à medida que, de 1968 em diante, o projeto panafricanista de Nkrumah tornou-se a tônica dos discursos e artigos do ativista.

\section{2. "Nós somos um mesmo povo": identidade diaspórica e o projeto pan-africanista de Stokely Carmichael no Atlântico Negro}

Marcado pelas suas viagens, Stokely Carmichael voltava aos Estados Unidos já fazendo planos de eventualmente retornar à Guine e atuar sob a orientação de Nkrumah. Às vésperas de 1968, o ano mais conturbado da década, o ativista aterrisou em Nova York em meio a um cenário político bastante incerto para o ativismo negro. Agora um revolucionário internacionalmente reconhecido, Stokely afastara-se por tempo considerável do movimento afro-americano e, sobretudo, do SNCC, o seu reduto político até então. Pela primeira vez, Carmichael encontravase sem uma base estável para dar continuidade à sua atuação no movimento Black Power. Para

389 "Perhaps the first weighty thing Osageyfo said to me - in our very first meeting - was about consciousness and the unity of our struggles. Whether we knew it or not, he said, the Afro-American struggle is inextricably linked to the struggle in Africa and vice-versa. Those of us who were conscious of this had a responsibility to make the connection clear to those who might be unaware. The single best weapon of the enemy, he said, was a lack of consciousness among our people". CARMICHAEL, Stokely; THELWELL, Ekwueme M. op. cit., p. 674-675. 
piorar, após uma tentativa frustrada de fusão com o Partido dos Panteras Negras, o SNCC atravessava profunda crise financeira e organizacional, indicando que um conflituoso desmanche se avizinhava. Disputando o controle do grupo, Carmichael e James Forman, um dos poucos ativistas da "velha guarda" do SNCC remanescentes, encontravam-se em lados opostos de uma rusga que terminou com o apoio dos Panteras Negras a Stokely e a sua subsequente expulsão do SNCC. Excluído da organização que havia antes presidido, o Partido passou a ser, então, o principal, senão o único, vínculo do ativista com o Movimento Black Power. ${ }^{390}$

Assim, em 1968, buscando estabelecer novas frentes de atuação, o ativista empenhou-se, de um lado, na organização do BUF - Black United Front, uma ambiciosa proposta de congregar vertentes divergentes do movimento negro em uma "frente unida" de organizações e ativistas; e, de outro, estreitou laços com os Panteras Negras, então a mais expressiva organização do movimento Black Power. Se no primeiro caso, o BUF provara-se uma iniciativa efêmera, incapaz de fomentar a coalizão política negra vislumbrada pelo ativista, o Partido, indicava, ao menos a princípio, um caminho promissor para o engajamento de Carmichael, especialmente após a liderança do grupo condecorá-lo com o título de Primeiro-Ministro Honorário. ${ }^{391}$

Preenchendo o vácuo deixado pelo SNCC, o Partido dos Panteras Negras crescia exponencialmente, transformando-se de uma organização restrita à Califórnia para a principal força política do movimento afro-americano após o assassinato de Martin Luther King em abril de 1968. Naquele momento, notabilizados pelas suas ações de patrulhamento armado da polícia, os militantes do grupo investiam em uma ampla mobilização em prol da libertação de Huey Newton - detido em outubro de 1967 sob acusação de homicídio de um policial branco em Oakland - e viram em Carmichael um forte aliado em potencial. Por sua vez, Stokely interessavase em ampliar sua influência sobre o Partido como maneira de difundir as ideias pan-africanistas com as quais tivera contato em suas viagens. Em pouco tempo, portanto, a campanha Free Huey rapidamente alastrou-se pelo país, englobando distintos setores do movimento negro e da Nova Esquerda universitária e contando com o envolvimento ativo de Stokely em diversos comícios pelo país. $^{392}$

\footnotetext{
${ }^{390}$ CARSON, Clayborne. In Struggle. SNCC and the Black Awakening of the 1960s. Harvard University Press, 1981, p. 287-293.

${ }^{391}$ JOSEPH, Peniel E. op. cit., 2014, p. 231-232.

${ }^{392}$ BLOOM, Joshua; MARTIN Jr., Waldo E. op. cit., p. 111-114.
} 


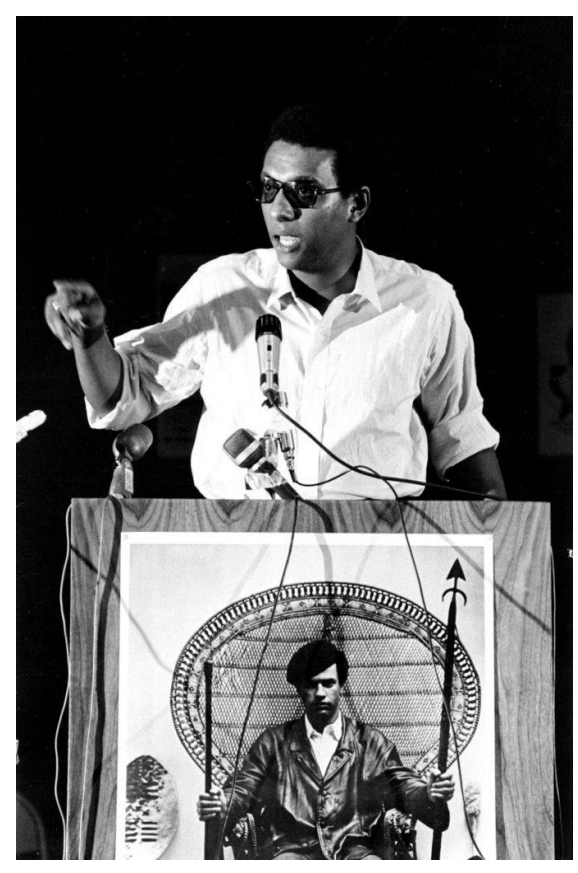

Imagem 12 - Em 1968, Stokely Carmichael participou de numerosos comícios em favor da soltura de Huey Newton, líder dos Panteras Negras encarcerado após confronto em Oakland que terminara com Newton gravemente ferido e um policial branco morto. Na imagem, Carmichael discursa em um púlpito ornado com a imagem icônica de Newton em um trono africano portando um rifle e uma lança. Fonte: Website Kilombagem. Disponível em: <https://kilombagem.net.br/educacao/biblioteca/stokelycarmichael-1941-1998-de-pantera-negra-a-pan-africanista/>. Acesso em: 28 de agosto de 2018.

Contudo, à medida que Stokely e os Panteras Negras aproximavam-se, tensões ideológicas entre as partes sugeriam que uma ruptura iminente estava prestes a ocorrer. Em fevereiro daquele ano, durante um importante comício organizado na cidade de Oakland por ocasião do aniversário de Newton, o pan-africanismo cada vez mais pronunciado de Carmichael já se destoava da orientação marxista-leninista e maoísta dos Panteras Negras e chocava-se com as alianças firmadas entre a liderança do grupo - em especial, Eldridge Cleaver - e os radicais antibelicistas da Nova Esquerda branca. ${ }^{393}$ Novamente, a obstinação de Stokely em conceber a autodeterminação negra em termos primordialmente "raciais" marcava suas críticas às formulações antirracistas assentadas sobre um viés de classe mais explícito. Discursando na ocasião, as divergências ideológicas latentes entre Carmichael e os Panteras tornaram-se públicas após ele disparar que o "socialismo e o comunismo são irrelevantes à luta do povo negro". 394

"As ideologias do comunismo e do socialismo tratam da estrutura de

\footnotetext{
${ }^{393}$ JOSEPH, Peniel E. op. cit., 2014, p. 271-272.

${ }^{394}$ MINOR, Ethel N. Editor's Preface. In: CARMICHAEL, Stokely. op. cit., 2007, p. XXI.
} 
classes, das pessoas que oprimem as outras de cima para baixo. Nós não estamos apenas enfrentando a exploração [econômica]. Estamos enfrentando algo muito mais importante porque somos vítimas do racismo. Na sua forma atual, nem o comunismo nem o socialismo tratam do problema do racismo. E para os negros neste país, o racismo vem em primeiro lugar, muito mais importante do que a exploração [econômica]".39

Não tardou, portanto, para que o tom dos discursos de Carmichael o indispusesse junto à liderança dos Panteras Negras, dando lugar a rivalidades políticas irreconciliáveis que culminaram, também, no rompimento definitivo do ativista com o grupo em meados do ano seguinte. ${ }^{396}$ No entanto, é necessário ressaltarmos que, a despeito da contundência de sua fala, as declarações do militante não implicavam uma recusa incondicional do marxismo. Como vimos anteriormente, mesmo que tivesse reservas contra o que julgava ser o caráter "eurocêntrico" dessa linha de pensamento, o ativista combinava, em seu posicionamento, uma releitura "terceiromundista" do marxismo inspirada pelas reflexões de Fanon, Che Guevara, dentre outros, ao nacionalismo negro de Malcolm X para formar uma agenda anticapitalista bastante definida. ${ }^{397}$ Ademais, veremos à frente que tal releitura ganhou, ainda, outros matizes à medida que o ativista aderia às perspectivas pan-africanistas de Kwame Nkrumah.

No calor dos embates políticos, contudo, os meandros do posicionamento de Carmichael perderam-se na polêmica declaração de que "o socialismo e o comunismo são irrelevantes à luta do povo negro", o que acarretou críticas direcionadas ao ativista por setores das esquerdas das quais ele se aproximara. Não por acaso, portanto, a pedido do militante, Ethel Minor, a editora do volume Stokely Speaks (1971), suprimira esse trecho da versão impressa do discurso, argumentando que a declaração fora descontextualizada e que não expressava adequadamente o pensamento do militante acerca do tema. Nas palavras dela, Stokely em realidade se referia "[...] ao tipo estéril e obsoleto de marxismo-leninismo europeu que tantos 'radicais brancos' neste país estavam e ainda estão tentando empurrar entre os ativistas negros - uma ideologia que não lida

395 "The ideologies of communism and socialism speak to class structure, to people who oppress people from the top to the bottom. We are not just facing exploitation. We are facing something much more important, because we are the victims of racism. In their present form neither communism nor socialism speak to the problem of racism. And to black people in this country, racism comes first, far more important than exploitation". CARMICHAEL, Stokely. Free Huey. In: Black Power to Pan-Africanism. 2. ed. Lawrence Hill Books, 2007, p. 121.

396 JOSEPH, Peniel E. op. cit., 2014, p. 280.

${ }^{397}$ CARMICHAEL, STOKELY; THELWELL, Ekwueme M. op. cit., p. 633. Sobre o "marxismo terceiro mundista" discutido na abertura do capítulo, cf. ELBAUM, Max. op. cit., p. 41-42. 
com as realidades do racismo e da polarização racial mundial no século XX" ${ }^{398}$

Ou seja, Carmichael apropriava-se do marxismo de maneira seletiva, de acordo com as prioridades e ênfases de um programa político e intelectual antirracista que se voltava, decisivamente, ao pan-africanismo. Para ele, então, o movimento afro-americano precisava pautar-se por uma agenda que tratasse primeiro das questões relativas ao racismo e à solidariedade racial e, então, da pauta de classe referente à expropriação econômica. Assim, disputando influência política dentro do movimento Black Power com a liderança dos Panteras Negras, Stokely propunha um projeto político-identitário transnacional, pan-africano, que abarcasse a "necessidade de nos conectarmos com as 900 milhões de pessoas negras no mundo hoje". Segundo ele, isto fazia-se necessário uma vez que os negros norte-americanos constituiriam "um povo africano com uma ideologia Africana" que estava "vagando pelos Estados Unidos". 399

Nesse sentido, perante plateias de militantes e universitários afro-americanos, o ativista passara a postular que os negros de todas as partes do Atlântico possuíam uma unidade cultural originária, intrínseca, - o que Nkrumah definira, no contexto africano, como uma "personalidade" - que fora perturbada pelo histórico de dispersão e desumanização resultantes do tráfico Atlântico, da escravidão nas Américas e do colonialismo europeu em África. ${ }^{400}$ Segundo ele, os negros ligavam-se não pelo local ou país de seu assentamento - isto é, sua nacionalidade mas pelo pertencimento "racial", o denominador comum entre diáspora e o continente africano. Assim, enfatizando que “[...] a questão da comunidade negra não é uma questão de geografia, mas uma questão de cor”, Carmichael concebia a identidade cultural negra como o núcleo de uma

${ }^{398}$ Cf. MINOR, Ethel N. Editor's Preface. In: CARMICHAEL, Stokely. op. cit., 2007, p. XXI.

399 "We must therefore consciously strive for an ideology which deals with racism first, and if we do that we recognize the necesssity of hooking up with the 900 million black people in the world today" e "We are coming together. We are an African people with an African ideology, and we are wandering in the United States. We are going to build a concept of peoplehood in this country or there will be no country". CARMICHAEL, Stokely. Free Huey. In: . op. cit., 2007, p. 122; 130.

${ }^{400}$ Cunhado pelo pan-africanista Edward Wilmot Blyden, o conceito de "personalidade africana" foi introduzido por Kwame Nkrumah na obra Consciencism (1964) como uma tentativa de postular uma solidariedade pretensamente inata entre os africanos - isto é, para além da "raça" e das determinações históricas e sociais da identidade cultural - que fundamentasse o seu projeto de unificação política e econômica do continente. Para o ganês, os africanos ligavam-se por um "núcleo de princípios humanistas que subjaziam à sociedade tradicional africana", conformando um modo de organização social igualitário e coletivista. Incorporada por seus seguidores, essa concepção de uma "personalidade" e identidade "africanas" que remetiam ao período pré-colonial embasava, como veremos à frente, o projeto revolucionário ao qual Carmichael aderira. Para uma discussão detalhada do conceito, cf. MARCUSSI, Alexandre Almeida. op. cit., p. 270-280 e BINEY, Ama. op. cit., p. 119-121. 
comunidade transnacional e homogênea, um fenômeno que antecedia os desenraizamentos diaspóricos e conectava os negros cultural, subjetiva e politicamente à "Mãe África". ${ }^{401}$ Por essas razões, o militante referia-se a "negros" e "africanos" como categorias intercambiáveis, sinônimos que, em sua visão, designavam "um mesmo povo" unido por uma mesma "origem" que lhes fora negada pelos seus opressores:

“Há quem diga: 'Bem, somos negros norte-americanos'. Bobagem. Vocês não são nada além de africanos e vocês nada puderam fazer quanto ao lugar onde nasceram. O homem branco decidiu onde vocês nasceriam, quando nasceriam e como nasceriam. $\mathrm{O}$ fato de nós continuarmos falando isso de que 'Somos [norte-]americanos primeiro' é uma bobagem. Nós somos africanos. Nascemos na América porque o homem branco precisava de nós aqui e esta é a única razão para tal. Isto não faz de vocês [norte-]americanos por acidente. Isto faz de vocês um instrumento da América". 402

Com isso, Stokely buscava afirmar, contundentemente, a necessidade dos afro-americanos operarem uma ruptura decisiva com a territorialidade e a identidade nacional norte-americanas em favor de um pertencimento identitário negro transnacional e pan-africano. Ancorados na crença em uma unidade cultural e racial entre os povos da diaspóra, seus pronunciamentos construíam a África como o palco primordial da luta e das esperanças por emancipação do Atlântico Negro. Nesse sentido, clamava para que a diáspora negra direcionasse sua atenção, seus esforços e aspirações para o continente africano, tendo em mente que, de uma forma ou de outra, física ou subjetivamente, uma "volta para casa" se impunha: “É comum os defensores do panafricanismo assegurarem os Africanos da diáspora de que o pan-africanismo não significa um retorno à África. Recuso-me a fazer isso. [...] A África é o nosso lar. Mesmo que um homem não consiga voltar para casa, este é o seu último desejo em vida". ${ }^{403}$

\footnotetext{
${ }^{401}$ Ibidem, p. 115.

402 “There are some who say, 'Well, we're the black Americans'. Junk. You ain't nothing but an African, and you ain't had nothing to say about where you were born; the white man decided where you would be born, when you would be born, and how you would be born. For us to keep talking this junk about 'We're Americans first' - that's junk. We're Africans. We happened to be born in America because the white man needed us here, and that's the only reason why. That does not make you an American, incidentally. It makes you a tool of America". CARMICHAEL, Stokely. A New World to Build. In: 2007, p. 150-151. Itálicos nossos.

403 "It is usual procedure for advocates of Pan-Africanism to assure Africans of the diaspora that PanAfricanism does not mean returning to Africa. I refuse to do so. [...] Africa is our home. Even if a man cannot return home it is his dying wish". CARMICHAEL, Stokely. From Black Power Back To PanAfricanism. In: . op. cit., 2007, p. 225.
} 
Em suma, no decorrer de 1968, as perspectivas identitárias de Carmichael assumiram um caráter marcadamente "afrocêntrico" segundo o qual as múltiplas identidades e culturas do Atlântico Negro conformariam um mesmo núcleo definido, "original" e comum a toda a comunidade diaspórica. Isso, entretanto, não era tudo o que ele propunha. Ainda que a convicção do ativista de que todos os negros seriam "africanos" subscrevesse a uma fórmula a-histórica e essencialista - "fechada" ou "absolutista", nos termos empregados por Stuart Hall e Paul Gilroy da diáspora e do pertencimento racial; o projeto mobilizado por ele não se reduzia a um simples apelo às "raízes" ou à idealização de um passado pré-colonial idílico. ${ }^{404} \mathrm{Ou}$ seja, a vinculação identitária dos negros à "Mãe África" - o "lar ancestral” para o qual a diáspora deveria convergir - era reivindicada por Carmichael na medida em que representava o ponto de partida para a realização da utopia política postulada por Kwame Nkrumah: "a total libertação e unificação da África sob um governo socialista de todos os africanos". 405

\subsubsection{Carmichael, a AAPRP e o caminho para a revolução pan-africana}

Em 1969, o "programa” político pan-africanista de Stokely Carmichael assumiu contornos mais definidos após o ativista e sua esposa, Miriam Makeba, mudaram-se definitivamente para a Guiné em meio a um cenário político conturbado. Ao final de 1968, o último ano de residência integral do ativista em solo norte-americano, o acirramento da repressão política cobria os projetos radicais da militância - branca e, principalmente, negra - com um véu de incerteza. Respondendo à temporada de sublevações estudantis e revolucionárias que irrompiam mundo afora, em muitos lugares, forças políticas contrárias organizaram-se em torno de projetos políticos conservadores e, não raro, abertamente autoritários, como maneira de salvaguardar o status quo.

Nos Estados Unidos não foi diferente. Paralelamente ao assassinato de Martin Luther King Jr. em abril e à condenação de Huey Newton em setembro, a eleição do Republicano conservador Richard Nixon à presidência em novembro daquele ano constituía a faceta pública

${ }^{404}$ HALL, Stuart. Pensando a diáspora: reflexões sobre a terra no exterior. In: ; SOVIK, Liv (org.). Da diáspora: identidades e mediações culturais. 2a ed. Editora UFMG: Belo Horizonte, 2018, p. 30-38 e GILROY, Paul. op. cit., p. 33-39.

${ }^{405} \mathrm{Na}$ íntegra: "Modern-day Pan-Africanism, which finds its highest political expression in Nkrumahism, holds as its basic tenet the total liberation and unification of Africa under an All-African socialist government”. CARMICHAEL, Stokely. From Black Power Back To Pan-Africanism. In: op. cit., 2007, p. 225. Itálicos nossos. 
de uma plataforma de "lei e ordem" que J. Edgar Hoover e o FBI comandavam clandestina e ilegalmente contra o movimento afro-americano. Nesse contexto, diversos militantes alvos da repressão e assédio do COINTELPRO - o programa de contra-inteligência do FBI - terminaram encarcerados ou mortos enquanto outros tantos exilaram-se ou, como Stokely Carmichael, buscaram novas bases para dar continuidade à sua atuação política. ${ }^{406}$ Assim, a despeito de manter um perfil itinerante e retornar ao país para incursões políticas frequentes, em dezembro daquele ano, o ativista trocou os Estados Unidos pelo regime de Sékou Touré e do seu copresidente, Kwame Nkrumah. Naquele momento, a identificação política, afetiva e ideológica com os africanos - acrescida das circunstâncias adversas nos Estados Unidos em 1968 empurrava Carmichael mais e mais para a África.

Uma vez estabelecido em Conacri, Stokely assumiu o posto de um revolucionário integralmente dedicado à causa pan-africanista determinado a articular as aspirações políticas negras na diáspora aos movimentos por autodeterminação africanos. Sob os auspícios do regime de Sékou Touré na Guiné, Carmichael engajou-se na organização do AAPRP - All-African People's Revolutionary Party, partido concebido por Nkrumah em 1968 com o propósito de centralizar ideológica e politicamente as múltiplas forças revolucionárias atuantes na África. Composto originalmente por uma pequena célula de militantes reunida em torno do líder ganês exilado, o grupo reivindicava para si o papel de "vanguarda" dos movimentos armados que, segundo acreditavam seus membros e idealizadores, levariam à vitória do projeto de unidade continental representado por Nkrumah e Touré. ${ }^{407}$

Em linhas gerais, Stokely e a AAPRP baseavam-se em uma visão afrocêntrica do socialismo - chamada de "socialismo africano" por alguns autores - pela qual o cânone marxistaleninista deveria ser reinterpretado à luz dos desafios contemporâneos colocados pelas

\footnotetext{
${ }^{406}$ Criado pelo FBI na década de 1950 como ferramenta de "combate" ao Partido Comunista dos Estados Unidos (CPUSA), o COINTELPRO utilizava de práticas de calúnia e descrédito, intimidação, chantagem e até extermínio de lideranças e organizações consideradas subversivas pelo órgão federal. Na primeira fase do Movimento pelos Direitos Civis, Martin Luther King e Bayard Rustin da SCLC tornaram-se alvos de sua vigilância. No formato estabelecido pelo presidente do FBI J. Edgar Hoover em 1968, o programa voltou-se à militância do Movimento Black Power, com destaque especial ao Partido dos Panteras Negras e a lideranças do SNCC como Stokely Carmichael e H. Rap Brown, presidente do grupo a partir do fim da gestão de Stokely em 1967. BLOOM, Joshua; MARTIN Jr., Waldo E. op. cit., p. 200-203. Para uma discussão dos impactos do ano de 1968 nos Estados Unidos, cf. ISSERMAN, Maurice; KAZIN, Michael. op cit., p. 221-240.

407 Sobre a história da AAPRP, cf. o website oficial do grupo disponível em: < https://aaprpintl.org/historical-origins-of-the-a-aprp/>. Acesso em: 15 de novembro de 2018.
} 
independências e pelo neocolonialismo à construção dos Estados nacionais africanos. ${ }^{408}$ Essas apropriações e transformações da ortodoxia marxista no programa político pan-africanista de Carmichael logo ficaram evidentes em Pan-Africanism - Land and Power, o primeiro e mais importante artigo acerca do tema publicado pelo militante em novembro de 1969, no volume inaugural do periódico The Black Scholar. ${ }^{409}$ Ou seja, se perante o Partido dos Panteras Negras Stokely havia criticado o socialismo e o comunismo como uma forma de atingir a esquerda branca norte-americana e postular a primazia da unidade e solidariedade racial entre os negros, agora o ativista incorporava concepções marxistas em seus escritos, articulando-as aos objetivos revolucionários de Kwame Nkrumah para a África.

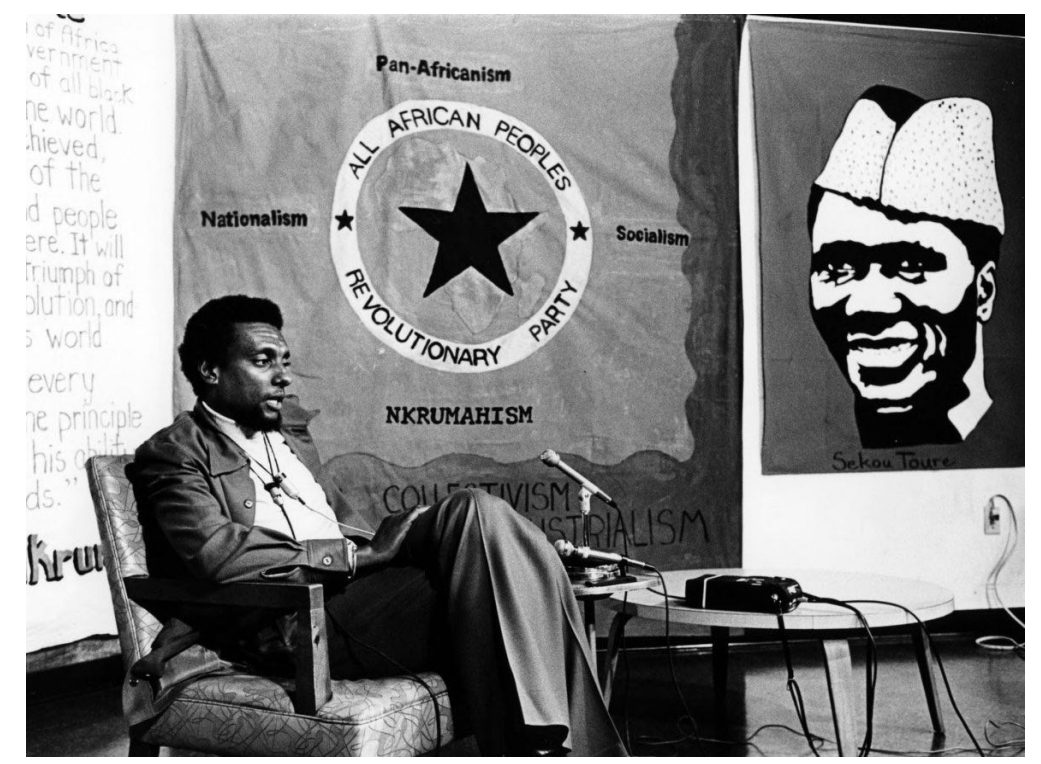

Imagem 13 - Stokely Carmichael já como militante pan-africanista na década de 1970. Ao fundo, estão representados o emblema do AAPRP - All-African Peoples Revolutionary Party, os princípios do partido (pan-africanismo, socialismo, "nkrumaismo" e nacionalismo) e uma imagem de Ahmed Sékou Touré.

408 O termo "socialismo africano" foi empregado para designar propostas de líderes africanos como o primeiro presidente da Tanzânia, Julius Nyerere (1922-1999), que concebiam modelos socialistas alternativos à ortodoxia marxista-leninista para a África. Para Nyerere, se o marxismo clássico não atentava à experiência da colonização e do racismo, o socialismo, por sua vez, não constituía um sistema desconectado da realidade africana. Ao contrário, ancorava-se diretamente nas culturas, modos de vida e estruturas sociais coletivas dos povos africanos que antecediam a chegada dos europeus no continente. Nesse sentido, embora ultimamente recusasse a alcunha de "socialismo africano" em favor da identificação com o "socialismo científico" mais convencional, Nkrumah em grande medida partilhava da busca dos seus contemporâneos por um caminho "africano" próprio em direção ao socialismo e à unidade continental. Cf. BINEY, Ama. op cit., p. 128-130.

${ }^{409} \mathrm{O}$ importante artigo Pan-Africanism - Land and Power não pôde ser acessado pela pesquisa em seu formato original de 1969. No entanto, em 1997, o texto foi reeditado na íntegra pela Black Scholar cuja versão tivemos acesso e utilizaremos aqui como referência. CARMICHAEL, Stokely. Pan-Africanism Land and power. Black Scholar, v. 27, n. 3/4, fall/winter 1997, p. 58-64. 
Fonte: Website do arquivo digital da North Carolina State University Libraries Digital Collections: Rare and Unique Materials. Disponível em: <https://d.lib.ncsu.edu/collections/catalog/0227527>. Acesso em: 10 de março de 2019.

Portanto, no artigo, seguindo fielmente o que propunha a "doutrina" política de Nkrumah - chamada de "nkrumaismo" pelos seus adeptos -, Carmichael defendia que haveria uma continuidade entre o caráter "coletivista" das sociedades africanas tradicionais e os princípios igualitários do "socialismo científico" de Marx, Engels e Lênin. Segundo essa visão, a África précolonial definia-se por seu "comunalismo", isto é, por um modo de organização social baseado em valores "humanistas" tradicionais e numa estrutura igualitária na qual os antagonismos de classe eram inexistentes e os meios de produção pertenciam à coletividade. Espécie de estágio socialista "embrionário", o comunalismo provaria, então, que o socialismo não era algo alheio ao continente e sim uma parte inerente à cultura tradicional, à história e "personalidade" africanas. Logo, não fosse a intervenção colonial europeia, argumentava Carmichael, a África completaria a utopia marxiana de uma sociedade livre da opressão através de um processo supostamente "natural”, "orgânico" e endógeno ao continente. Dessa maneira, na esteira das ideias de Nkrumah, Carmichael e a AAPRP articulavam uma versão esquemática do passado africano a um modelo revolucionário para o presente e uma projeção socialista de futuro ao continente e sua diáspora. $^{410}$

"No clássico livro de Osagyefo [Kwame Nkrumah], Consciencism, podemos ver que as teorias de Marx e Lenin têm suas raízes no comunalismo. Logo, sendo africano [leia-se negro], eu devo estudar o Nkrumaismo, que compreende que o comunalismo é o próprio alicerce do Marxismo-Leninismo. Ele abarca a minha história, a história africana, como ela deve ser apresentada para que 'se torne um ponteiro da ideologia que deve guiar e dirigir a reconstrução africana'. $O$ Nkrumaismo já estudou as teorias do marxismo-leninismo, acatando suas diretrizes universais e o seu método científico. No entanto, o Nkrumaismo volta-se à África, ao comunalismo, pois reconhece que, se a Mãe África tivesse permanecido intocada por forças externas, ela teria sido a primeira a alcançar o comunismo naturalmente, sem derramamento de sangue", 411

${ }^{410}$ BINEY, Ama. op cit., p. 125-130 e MARCUSSI, Alexandre Almeida. op. cit., p. 270-280.

411 "In Osagyefo's classical work Consciencism, we can see that the theories of Marx and Lenin have their roots in communalism. Thus, as an African, I should study Nkrumahism, which knows communalism contains the very foundation of Marxism-Leninism. It contains my history, African history, as it must be presented In order to 'become a pointer at the ideology which should guide and direct African 
Em outras palavras, para ele, a revolução pan-africana inevitavelmente se cumpriria, mas segundo uma lógica etapista e "científica" própria previamente decifrada pelo ex-presidente ganês. Conjugando a imagem de um passado idealizado à projeção de uma África unificada e socialista, o ativista e a AAPRP entendiam que a libertação negra no Atlântico dependia da articulação das forças da diáspora e do continente em torno das lutas que visavam livrar o continente do jugo imperial e do capitalismo neocolonial. Afinal, "conforme diz Nkrumah", discorre o programa ideológico do grupo, "para nós, africanos e pan-africanistas, 'o núcleo da revolução negra está na África e até que a África esteja unida sob um governo socialista, o homem negro de todo o mundo não terá um lar nacional"," 412

No entanto, para que esse objetivo fosse atingido, um último aspecto impunha-se à revolução antirracista e anticapitalista pretendida por Carmichael e pela AAPRP em África: a construção de bases revolucionárias por meio da luta armada. Em seus artigos e discursos na transição entre as décadas de 1960 e de 1970, o ativista defendia que o recurso a ações militares no continente fazia-se necessário para a expansão do pan-africanismo e para a derrocada dos regimes africanos que se encontravam sob a alçada de forças externas. Adaptando um princípio do marxismo clássico, Stokely estipulava que tal (re)tomada territorial pela força das armas fosse por novas investidas ou pelos movimentos de libertação em vigor - asseguraria a "infraestrutura" material necessária à sobrevivência da revolução e à consolidação de uma "superestrutura" política, cultural, ideológica em benefício dos negros de todo o Atlântico. Por isso, argumentava ele, o retorno de Nkrumah ao poder em Gana constituiria o primeiro passo a ser dado em direção à construção da "nação continental africana" e à "libertação total do nosso povo" no continente e na diáspora. ${ }^{413}$

"Malcolm $X$ disse que luta-se pela revolução, mas que, em última instância, a revolução é baseada na terra. Ele estava absolutamente

reconstruction'. Nkrumahism has already studied the theories of Marxism-Leninism, acceting their universal guidelines and scientific method. And Nkrumahism returns to Africa, returns to communalism, because Nkrumahism knows that if Mother Africa had been left untrampled by alien forces she would have been the first to achieve communism naturally, without bloodshed". CARMICHAEL, Stokely. PanAfricanism - Land and Power, p. 60-61. Itálicos nossos.

412 "For us as Africans and Pan-Africanists as Nkrumah says, 'the core of the black revolution is in Africa and until Africa is united under a socialist government, the black man throughout the world lacks a national home"'. In: Overview of Essential Aspects of Nkrumahism-Touréism: Ideology of the AAPRP. Disponível em: <https://aaprp-intl.org/ideology-of-the-aaprp/>. Acesso em: 28 de março de 2018.

${ }^{413}$ CARMICHAEL, Stokely. Message from Guinea. In: op. cit., 2007, p. 181. 
correto. Você precisa de terra para produzir, para alimentar, abrigar e vestir o seu povo. [...] As pessoas não lutam simplesmente por idéias a menos que tenham certeza de que conseguem ver uma condição melhor de vida emergindo dessas idéias. [...] Temos que ter uma base territorial. $\mathrm{Eu}$ acho que o melhor lugar para isso é a África e, na África, o melhor lugar é Gana. Os negros nos Estados Unidos, enquanto isso, devem começar a entender que é preciso um aprimoramento em nossas ideologias. Nossa ideologia deve ser o pan-africanismo e nenhuma outra. Estou quase convencido disso. Uma vez que tivermos uma base territorial, poderemos começar a experimentá-la, desenvolvê-la e engajar-nos nas tarefas concretas de construção nacional". 414

Assim, após aderir ao pan-africanismo, o projeto político-identitário de Carmichael assumira um formato transnacional marcadamente distinto das suas proposições para os movimentos pelos Direitos Civis e Black Power nos Estados Unidos. O militante voltara-se, então, a uma perspectiva revolucionária de transformação social segundo a qual a emancipação dos negros de todas as formas de opressão estava condicionada à utopia de uma África socialista, política, territorial, cultural e economicamente unificada. Atuando na AAPRP, Stokely ressignificava suas lutas contra a segregação racial e o racismo institucional norte-americanos na década anterior à luz da centralidade que atribuía ao cenário político africano. Para ele, a chave para a autodeterminação e libertação negras não residia mais, como propusera durante o Black Power, na construção de uma identidade negra nacional no interior da "América Branca" ou mesmo na luta terceiro-mundista contra o "Ocidente Branco", mas, sobretudo, na confluência da diáspora em uma mesma comunidade transnacional de sentido e pertencimento: a "nação africana". Em suma, conforme definido por Carmichael no último documento compilado em Stokely Speaks:

“O pan-africanismo baseia-se na crença de que a África é uma só, as fronteiras artificiais são o resultado da conferência de Berlim quando as potências européias dividiram o continente e dividiram os espólios entre

\footnotetext{
414 "Malcolm X said that one fights for revolution but that in the final analysis revolution is based on land. He was absolutely correct. You have to have land in order to produce, in order to feed, shelter and clothe your people. [...] People do not just fight for ideas, unless they are sure they can see a better way of life coming out of those ideas. [...] We have to have a land base. I think that the best place for that is Africa, and in Africa the best place is Ghana. Black people in the United States meanwhile must begin to understand that there needs now to be a clear sharpening of our ideologies. Our ideology must be PanAfricanism, nothing else. I am almost convinced of that. Once we get a land base, we can begin to experiment with it and develop it and go about the concrete tasks of nation building". CARMICHAEL, Stokely. Pan-Africanism - Land and Power, p. 61-62. Itálicos nossos.
} 
si. O pan-africanismo baseia-se na crença de que todos os povos africanos, onde quer que estejamos, são um só e, como diz o Dr. Nkrumah, 'pertencem à nação africana': nossa dispersão foi o resultado do imperialismo europeu e do racismo. O pan-africanismo é baseado no socialismo que tem suas raízes no comunalismo. Qualquer ideologia que busque resolver os problemas do povo africano [leia-se negro] deve encontrar suas raízes no pan-africanismo". 415

Por fim, em princípios dos anos 1970, a ruptura de Stokely Carmichael com os Estados Unidos, país onde ele se tornou reconhecido nacional e internacionalmente, completava as transformações nas perspectivas do militante iniciadas durante os seus primeiros anos à frente do Movimento Black Power (1966-1967). Naquele período, como vimos no capítulo anterior, ao clamar por autodeterminação e orgulho negros, o ativista sobrepunha uma identidade negra à norte-americana sem romper plenamente, ainda, com os limites territoriais nos quais esta última se assentava. Entretanto, após suas viagens pelo "Terceiro Mundo", isso mudou. Radicando-se na África, Stokely terminou por distanciar-se da cena norte-americana em prol de um programa político e de uma identidade negras transnacionais - que incluíam os negros norte-americanos baseadas na crença em uma unidade intrínseca entre a diáspora e o continente africano. Mudando seu nome para Kwame Ture em homenagem a Sékou Touré e Kwame Nkrumah, Carmichael julgava que somente a utopia política traçada pelos seus mentores seria ultimamente capaz de cumprir as aspirações por liberdade e autodeterminação há séculos buscadas por gerações de ativistas e intelectuais do Atlântico Negro. A essas perspectivas, tornadas certezas, Ture agarrouse pelo resto da vida.

415 "Pan-Africanism is grounded in the belief that Africa is one; the artificial borders being the result of the Berlin conference, where European powers have carved up the continent and divided the spoils among themselves. Pan-Africanism is grounded in the belief that all African peoples, wherever we may be, are one, and as Dr. Nkrumah says, 'belong to the African nation'; our dispersal was the result of European imperialism and racism. Pan-Africanism is grounded in socialism which has its roots in communalism. Any ideology seeking to solve the problems of the African people must find its roots in Pan-Africanism". CARMICHAEL, Stokely. From Black Power Back To Pan-Africanism. In: . op. cit., 2007, p. 221. 


\section{CONSIDERAÇÕES FINAIS}

\section{De Stokely Carmichael a Kwame Ture: possibilidades e contradições de uma trajetória pelo}

\section{Atlântico Negro}

"Talvez, tendo nascido em Trinidad [e Tobago], e tendo sempre seguido as lutas de Independência no Caribe e na África tanto quanto a luta nos Estados Unidos, eu tinha uma perspectiva um pouco diferente de muitos dos meus colegas do movimento pelos Direitos Civis. Eu nunca senti que a América fosse a única ou mesmo a principal arena da nossa luta. [...] Sempre achei que a luta era uma. Nenhuma luta justa em qualquer lugar do mundo africano era estranha para mim. Eu sentia fortemente que era simplesmente uma questão de onde e de como, a qualquer momento, alguém poderia dar a maior contribuição". ${ }^{16}$

No dia 16 de novembro de 1998, um singelo artigo no New York Times anunciava: "Stokely Carmichael, líder dos Direitos Civis que cunhou o 'Black Power', morre aos 57 anos". ${ }^{417}$ Falecido precocemente em Conacri, Guiné, no dia anterior, Carmichael lutava, havia cerca de dois anos, contra um câncer agressivo diagnosticado demasiado tarde. Durante seu tratamento médico nos Estados Unidos e em Cuba, diversos aliados e até adversários de longa data entraram em contato com Stokely para despedirem-se do líder veterano que, décadas antes, inflamara a cena pública norte-americana durante os movimentos pelos Direitos Civis e Black Power dos anos 1960. Fragilizado e grisalho, Carmichael, agora respondendo pelo nome de Kwame Ture, chegava ao fim de uma sinuosa e complexa trajetória marcada por constantes reinvenções e rupturas em sua imagem pública, pensamento, engajamento políticos e filiações identitárias.

Percorrendo o Atlântico Negro, a atuação política de Stokely constituiu-se em meio a sucessivos deslocamentos pelas Américas, Europa e África característicos do dinamismo cultural,

416 "Perhaps being born in Trinidad, and having always followed the Independence struggles in the Caribbean and Africa as much as the American struggle, I had a somewhat different perspective from many of my colleagues in the civil rights movement. I have never felt that America was the only or even the primary arena of our struggle. [...] I had always thought the struggle was one. No righteous struggle anywhere in the African world was alien to me. I felt strongly that it was simply a matter of where and how at any given time one could make the greatest contribution". Itálicos do autor. CARMICHAEL, Stokely; THELWELL, Ekwueme Michael. op. cit., p. 625.

${ }^{417}$ KAUFMAN, Michael T. Stokely Carmichael, rights leader who coined "Black Power", dies at 57. The New York Times, 16 nov. 1998, p. 10. 
político e dos desenraizamentos populacionais que compõem a diáspora negra no mundo contemporâneo. Após deixar o Caribe colonial na década de 1950, Carmichael destacou-se como um ativista e intelectual comprometido com a articulação de distintos projetos políticos e perspectivas identitárias para a militância negra que lutava contra o racismo nos Estados Unidos.

Em princípios dos anos 1960, a geração de Stokely formou-se politicamente cercada pelos eventos marcantes do Movimento pelos Direitos Civis durante o qual lideranças negras integracionistas, separatistas e estudantis imprimiam novas dinâmicas à luta contra o sistema de segregação racial (as leis Jim Crow) no Sul do país e à discriminação institucionalizada nas grandes cidades do Norte e Oeste. Buscando, inicialmente, acesso às garantias mínimas da cidadania norte-americana, o ativista e seus colegas do SNCC organizaram-se em torno de uma ampla agenda reformista (liberal) pautada pelo emprego da desobediência civil não-violenta como uma estratégia de luta pelo direito de voto, representação política e pela integração dos negros à vida pública nacional.

Contudo, como vimos no segundo e terceiro capítulos, em meados da década essa perspectiva havia mudado. Convencidos de que a integração dos negros à sociedade norteamericana provara-se um objetivo ilusório, incapaz de dissolver as amarras sistêmicas do racismo nos Estados Unidos, Stokely e muitos outros militantes negros voltaram-se ao Black Power, movimento que clamava por transformações fundamentais nos valores, sensibilidades, instituições e identidades nacionais. Nesse contexto, assumindo o papel de um intelectual público, representante e porta-voz da militância negra que se radicalizava, o ativista engajou-se em uma série de publicações e discursos em prol do seu novo projeto político. Em sua principal obra do período, Black Power: The Politics of Liberation, Carmichael e Hamilton sintetizaram suas perspectivas para o Black Power ao defenderem a necessidade dos afro-americanos fortalecerem uma identidade cultural negra assertiva e orgulhosa, distinta da norte-americana (branca), e partirem ao controle político e econômico de suas comunidades. Em pouco tempo, o tênue vínculo então mantido pelo ativista com a comunidade e identidade nacionais norteamericanas chegou ao seu ponto de ruptura.

Ao final dos anos 1960, as perspectivas de Stokely Carmichael para o movimento negro nos Estados Unidos assumiram, ainda, contornos revolucionários e transnacionais marcantes. Em 1967, após uma série de viagens e sociabilidades políticas pelo “Terceiro Mundo", o ativista associava a luta afro-americana por Black Power diretamente aos movimentos e revoluções em 
vigor entre as vítimas da colonização e do imperialismo ocidentais. Para ele, como observamos na documentação reunida em Stokely Speaks: From Black Power to Pan-Africanism, a autodeterminação negra buscada pelo Black Power estava, então, intimamente relacionada às aspirações "terceiro-mundistas" por libertação e soberania nacionais manifestas por asiáticos, latino-americanos e, principalmente, africanos. Aos poucos, as ideias de Kwame Nkrumah tornaram-se a tônica dos seus escritos e pronunciamentos públicos, fazendo com que o projeto político-identitário de Stokely adotasse uma orientação socialista e diaspórica particular. Assim, no crepúsculo dos tumultuosos anos 1960 e início da década de 1970, a luta do ativista pela unificação do continente africano estava no cerne de um projeto político-identitário pan-africano que visava emancipar os povos do Atlântico Negro de todas as formas de opressão.

Naquele contexto, contudo, as convicções revolucionárias de Carmichael já perdiam espaço diante dos contornos cada vez mais moderados assumidos pelo movimento negro nos Estados Unidos. Entre a segunda metade dos anos 1960, momento no qual o ativista estivera à frente do Black Power, até meados da década de 1970, o cenário político nacional norteamericano deslocou-se decisivamente à direita, trazendo drásticas mudanças ao ativismo afroamericano. Paralelamente à repressão política orquestrada pelo COINTELPRO contra as lideranças negras dos anos 1960, uma "Nova Direita" - cujo grande representante, Ronald Reagan, chegaria à presidência do país pouco mais de uma década depois - abrigava-se no Partido Republicano sob uma plataforma de "lei e ordem" dedicada à supressão dos projetos de transformação social nos Estados Unidos. Como consequência, o movimento Black Power e a Nova Esquerda se desarticulavam em meio à exaustão dos ativistas, à perseguição política e à difusão de disputas internas, práticas antidemocráticas e sectárias em organizações como SNCC, o Partido dos Panteras Negras, a SDS, o DRUM, dentre outras. Boa parte do ativismo no país voltou-se, então, às ações afirmativas como modo de inclusão social. Chegava ao fim uma etapa crucial da história norte-americana durante a qual Stokely Carmichael desempenhou um papel central. $^{418}$

Não é de se espantar, portanto, que, diante do avanço gradativo da pauta conservadora na vida pública e na política norte-americanas, as agendas nacionalista negra, pan-africanista e revolucionária características do movimento Black Power e da Nova Esquerda recuassem,

\footnotetext{
${ }^{418}$ ELBAUM, Max. op. cit., p. 5; 7-8 e FRAZER, Steve; GERSTLE, Gary. (orgs). The Rise and Fall of the New Deal Order, 1930-1980. Princeton University Press, 1989.
} 
cedendo espaço para abordagens mais ajustadas ao reformismo político. De um lado, o vácuo deixado pelas forças radicais teve como uma importante consequência favorecer o reencontro entre a política negra e a política "oficial". Assim, ainda que Stokely Carmichael e uma minoria de radicais remanescentes preterissem os canais institucionais em favor de programas negros independentes e revolucionários, um número crescente de negros recorria à disputa partidária por agências governamentais, programas sociais e campanhas eleitorais. Exemplos disso, nos anos de 1970, grupos de interesse e articulação política como o Congressional Black Caucus e o Joint Center for Political Studies conquistaram influência no cenário nacional, enquanto máquinas Democratas fortaleceram-se localmente com a eleição de prefeitos afro-americanos e hispânicos nas cidades de Atlanta, Newark, Gary, Birmingham, Denver, Detroit, Chicago e San Antonio. ${ }^{419}$

Em alguns casos, mesmo dentro de organizações identificadas com perspectivas radicais, o recurso à política eleitoral passou a ser cada vez mais mobilizado por alguns de seus membros. Foram os casos, por exemplo, do apoio dado pelo SNCC à candidatura do ativista do grupo Julian Bond à Assembléia do Estado da Georgia já em 1965 e da campanha dos Panteras Negras Bobby Seale e Elaine Brown para as eleições municipais de Oakland, Califórnia, em 1972. Na ausência de um movimento de massas, boa parte da militância negra enxergava, então, os "canais políticos oficiais" como o caminho disponível para dar continuidade às suas reivindicações por conscientização política-identitária, redistribuição de renda, bens e serviços em favor dos afroamericanos necessitados. $^{420}$

Ao mesmo tempo, também na década de 1970, lideranças masculinas do Black Power como Stokely Carmichael recebiam algumas de suas mais contundentes (e devidas) críticas vindas de quadros do próprio movimento negro: ativistas e, posteriormente, teóricas do feminismo negro passaram a denunciar a invisibilidade da mulher negra e das questões de gênero nos programas e perspectivas dos grupos nos quais militavam. Críticas dos papéis de gênero a elas designados em organizações como o SNCC e o Partido dos Panteras Negras, essas ativistas e intelectuais introduziram, dentro e fora do movimento afro-americano, a interseccionalidade como conceito-chave de uma resistência conjunta à opressão racial, de gênero e de classe. ${ }^{421}$ Suas

${ }^{419}$ OMI, Michael; WINANT, Howard. op. cit., p. 175.

${ }^{420}$ Ibidem, p. 175-176 e BLOOM, Joshua; MARTIN Jr., Waldo E. op. cit., p. 379-381.

421 ANDERSON-BRICKER, Kristin. "Triple Jeopardy": black women and the growth of feminist consciousness in SNCC, 1964-1975. In: SPRINGER, Kimberly (org.). Still lifting, still climbing. African American women's contemporary activism. New York and London: New York University Press, 1999, p. 59-62. VANDEBURG, William L. op. cit., p. 296-298. 
reflexões e ações em prol desta "tripla libertação" abriram um vasto campo de atuação política e de produção intelectual/acadêmica cujo impacto atravessou as águas do Atlântico Negro fazendose sentir, inclusive, no Brasil. Atualmente, o feminismo negro é cada vez mais (re)apropriado pelas mulheres e intelectuais negras brasileiras como um referencial político fundamental à reflexão teórica e à luta pelo que a filósofa Djamila Ribeiro definiu como um "novo marco civilizatório". ${ }^{422}$

Além do mais, nesse mesmo período, a Guerra Fria ingressava em um outro momento marcado pelo advento da coexistência pacífica (détente) entre norte-americanos e soviéticos e, também, pela surpreendente aproximação diplomática entre os Estados Unidos e a China comunista - até então considerada um modelo de resistência ao imperialismo "ianque" no "Terceiro Mundo". Com o arrefecimento das tensões e os realinhamentos estratégicos entre as potências em princípios dos anos setenta, as forças capitalistas e socialistas presenciaram a desaceleração da corrida armamentista da Guerra Fria e o aprofundamento das divisões no seio do campo comunista internacional. ${ }^{423}$ Nesse novo cenário, portanto, os desdobramentos da Revolução Cubana, os limites da luta armada e a consolidação de regimes ditatoriais na África já impunham reflexões e críticas aos Estados e perspectivas revolucionárias adotadas por Carmichael enquanto intelectual engajado.

Em suma, todas essas mudanças trouxeram, a partir da década de 1970, novas dinâmicas e questões ao ativismo afro-americano às quais Carmichael, agora Kwame Ture, permanecera em grande medida alheio, observando-as à distância. Sediado em Conacri, Ture continuou engajado no projeto de consolidação e difusão da AAPRP como a vanguarda pan-africanista que uniria as forças da diáspora e os movimentos de libertação em torno do confronto pela unificação do continente. Àquela altura, contudo, ao passo que a política negra norte americana se reconfigurava, as proposições do militante perdiam espaço e não mais detinham o apelo característico dos anos do Black Power.

Em certas ocasiões, sua insistência na inevitabilidade da revolução socialista e panafricana chegava a causar estranheza entre públicos que não mais partilhavam do léxico radical de finais dos anos 1960. Assim, nas décadas subsequentes, para a surpresa de boa parte daqueles que assistiram-no discursar nos Estados Unidos - dentre eles, Barack Obama, jovem estudante da

\footnotetext{
${ }^{422}$ RIBEIRO, Djamila. Quem tem medo do Feminismo negro? São Paulo: Companhia das Letras, 2018, p. 27.

${ }^{423}$ ELBAUM, Max. op. cit., p. 207-221.
} 
Columbia University nos anos 1980 - o engessamento das perspectivas de Ture tornara-se visível. Atuando como um ideólogo e difusor do "nkrumaismo", as incursões do militante pelas universidades norte-americanas revelavam uma linha política inflexível em franco contraste com o ativismo comunitário, a democracia participativa e as propostas por autodeterminação negra pelas quais ele se notabilizara no decorrer da década. ${ }^{424} \mathrm{Se}$, naqueles anos, o Black Power empunhado por Carmichael fora decisivo para o desenvolvimento de propostas negras por orgulho, consciência identitária e ações afirmativas que chegaram aos dias atuais, da década de setenta em diante, o ativista não mais mobilizava como antes.

Ficava claro, então, que as perspectivas de transformação social, organização de base e reflexão intelectual características da atuação de Stokely Carmichael na década de 1960 foram drasticamente impactadas pelas filiações políticas que se seguiram à sua reinvenção como Kwame Ture. Mergulhado nos processos de descolonização e cercado por projetos de construção nacional antagônicos em África, o militante agarrou-se a formulações ideologicamente esquemáticas e a posicionamentos autoritários, além de estabelecer alianças condenáveis com ditadores africanos como o líbio Muammar Ghadaffi e o terrível Idi Amin de Uganda. ${ }^{425} \mathrm{O}$ culto às lideranças de Kwame Nkrumah - Osagyefo, o "redentor" - e Sékou Touré tornou-se, como sugerimos no último capítulo, uma das marcas registradas dos seus discursos e artigos. Convicto do caráter "científico" e da "retidão" da doutrina pan-africanista dos seus mentores, Ture consentiu ao recrudescimento do regime guineense após sucessivos atentados à vida do presidente Touré e a uma invasão frustrada do país orquestrada por mercenários portugueses vindos da Guiné-Bissau em 1972. ${ }^{426}$

Naquele momento, portanto, Ture já se encontrava intimamente vinculado ao regime ditatorial na Guiné, o que, nas décadas seguintes, comportou paradoxos evidentes ao seu posicionamento político. A partir de então, enquanto o militante exaltava as "virtudes" do governo de Sékou Touré e postulava a vitória do pan-africanismo revolucionário contra as forças neocoloniais no continente, a repressão interna aos adversários políticos do presidente guineense produzia milhares de prisioneiros no Campo Boiro, o "gulag" do país. Pouco antes de morrer, tratando das terríveis denúncias de torturas, mortes e violações aos Direitos Humanos cometidas contra os opositores de Touré detidos em Boiro, Kwame Ture não hesitou em minimizar os

\footnotetext{
${ }^{424}$ JOSEPH, Peniel E. op. cit., 2014, p. 325

${ }^{425}$ Ibidem, p. 300-306.

${ }^{426}$ Ibidem, p. 300-306 e CARMICHAEL, Stokely; THELWELL, Ekwueme Michael. op. cit., p. 699-702.
} 
relatos alegando tratarem-se, em sua maioria, de "fabricações deliberadas ou grosseiramente exageradas". Ainda, nas palavras dele, mesmo que não houvesse dúvidas acerca das "duras condições" no campo, este fizera-se "necessário para defender a revolução por quaisquer meios necessários". Impassível, às vésperas do novo milênio, Ture despediu-se em sua autobiografia com a saudação que reafirmava a mesma certeza doutrinária dos vinte anos anteriores: "Pronto para a Revolução!". 427

Por fim, construída no âmbito das culturas e tradições políticas do Atlântico Negro, a transformação de Stokely Carmichael em Kwame Ture desvela ao observador contemporâneo uma trajetória de marcante resistência à opressão, aguçada crítica social, constantes reconfigurações identitárias e, também, profundas contradições. Produto das disputas e aspirações políticas de sua época, Carmichael/Ture engajou-se na luta contra os legados desumanizantes da escravidão, segregação racial e do colonialismo, almejando, através dos seus escritos e ações, trazer à tona uma realidade outra, verdadeiramente digna, para os negros de todo o Atlântico. No caminho, traçou diagnósticos distintos acerca da natureza da opressão racial articulando-os aos programas políticos e identitários que prescrevia à militância afro-americana, terceiro-mundista e africana com o fervor que lhe era característico. Em última instância, o ativista atuou em prol de novas possibilidades para o negro ser e estar no mundo, vislumbrando o dia em que a derrocada do racismo e da marginalização social libertariam a população negra das arraigadas estruturas da opressão. Atravessados por rupturas e reinvenções constantes, o pensamento e a atuação de Carmichael/Ture convidam-nos a refletir acerca do potencial e dos impasses legados pelos projetos de transformação social da década de 1960 às mais distintas - e não menos urgentes lutas dos dias atuais.

${ }^{427}$ CARMICHAEL, Stokely; THELWELL, Ekwueme Michael. op. cit., p. 688; 781. 


\section{REFERÊNCIAS BIBLIOGRÁFICAS GERAIS}

\section{- Fontes da pesquisa:}

CARMICHAEL, Stokely; HAMILTON, Charles V. Black Power: The Politics of Liberation. 2. ed. New York: Vintage Books, 1992.

CARMICHAEL, Stokely. Stokely Speaks: From Black Power to Pan-Africanism. 2. ed. Lawrence Hill Books, 2007.

. El Tercer Mundo, Nuestro Mundo. Tricontinental, v. 1., n. 1, jul. - ago. 1967, p. 15-21. . Pan-Africanism - Land and power. Black Scholar, v. 27, n. 3/4, fall/winter 1997, p. 5864.

.; THELWELL, Ekwueme M. Ready for the Revolution: The Life and Struggles of Stokely Carmichael (Kwame Ture). New York: Scribner, 2003.

\section{- Livros, teses e dissertações consultados:}

ABU-LUGHOD, Janet L. Race, space and riots in Chicago, New York, and Los Angeles. Oxford University Press, 2007.

ALEXANDER, Michelle. A Nova Segregação. Racismo e encarceramento em massa. São Paulo: Boitempo, 2017.

ALMEIDA, Silvio. O que é racismo estrutural? Belo Horizonte: Editora Letramento, 2018.

ANDERSON, Benedict. Comunidades imaginadas: reflexões sobre a origem e a difusão do nacionalismo. São Paulo: Companhia das Letras, 2008.

BLOOM, Joshua; MARTIN Jr., Waldo E. Black against Empire: The history and politics of the Black Panther Party. Oakland: University of California Press, 2016.

BINEY, Ama. The political and social thought of Kwame Nkrumah. New York: Palgrave MacMillan, 2011.

CARBADO, Devon W.; WEISE, Don. Time on two crosses: The collected writings of Bayard Rustin. 2a ed. Cleis Press, 2015.

CARSON, Clayborne. In Struggle. SNCC and the Black Awakening of the 1960s. Harvard University Press, 1981.

CRUSE, Harold. The Crisis of the Negro Intellectual: a Historical Analysis of the Failure of 
Black Leadership. New York: New York Review Books, 2005.

CLARK, Kenneth B. Ghetto negro: los dilemas del poder social. México: Fondo de Cultura Económica, 1968.

COATES, Ta-Nehisi. Entre o mundo e eu. Rio de Janeiro: Objetiva, 2015.

ELBAUM, Max. Revolution in the air. Sixties radicals turn to Lenin, Mao and Che. 2a ed. London \& New York: Verso, 2018.

FANON, Frantz. Os Condenados da Terra. 3a reimpressão. Juiz de Fora: Editora UFJF, 2015. . Pele negra, máscaras brancas. Salvador: EDUFBA, 2008.

FAUSTINO, Deivison M. Frantz Fanon - Um revolucionário particularmente negro. São Paulo: Ciclo Contínuo Editorial, 2018.

FRANCISCO, Flávio Thales Ribeiro. O Novo Negro na Diáspora. Modernidade Afro-Americana e as Representações sobre o Brasil e a França no Jornal Chicago Defender (19161940). São Paulo: Intermeios, 2016.

FRAZER, Steve; GERSTLE, Gary. (orgs). The Rise and Fall of the New Deal Order, 1930-1980. Princeton University Press, 1989.

FREEMAN, Joshua B. American Empire. The rise of a global power, the democratic revolution at home, 1945-2000. New York: Penguin Books, 2013.

GENEROSO, Lidia Maria de Abreu. "O povo colonizado não está sozinho”: Terceiro Mundo, anti-imperialismo e revolução nas páginas da revista Tricontinental (1967-1976). Dissertação de Mestrado - Instituto de Ciências Humanas e Sociais. Universidade Federal de Ouro Preto: Mariana, 2018.

GERSTLE, Gary. American Crucible: Race and Nation in the Twentieth Century. Princeton and Oxford: Princeton University Press, 2002.

GILROY, Paul. O Atlântico Negro. Modernidade e dupla consciência. São Paulo: Editora 34, 2001.

HALL, Stuart. A identidade cultural na pós-modernidade. Rio de Janeiro: Lamparina, 2015.

; SOVIC, Liv (org.). Da Diáspora. Identidades e Mediações Culturais. Belo Horizonte: Editora UFMG, 2003.

HERNANDEZ, Leila Leite. A África na sala de aula. Visita à História Contemporânea. 2a edição revista. São Paulo: Selo Negro, 2008.

ISSERMAN, Maurice; KAZIN, Michael. America Divided: The Civil War of the 1960s. Oxford 
University Press, 2000.

JAMES, C.L.R. Os Jacobinos Negros: Toussaint L'Ouverture e a Revolução de São Domingos. Boitempo, 2007.

JEFFRIES, Hasan Kwame. Bloody Lowndes. Civil Rights and Black Power in Alabama's Black Belt. New York: New York University Press, 2009.

JONES, Charles E. (org.). The Black Panther Party Reconsidered. Edição Kindle. Black Classic Press, 2013.

JOSEPH, Peniel E. Dark Days, Bright Nights: From Black Power to Barack Obama. New York: Basic Civitas Books, 2009. .(org.). The Black Power Movement. Rethinking the Civil Rights-Black Power Era. New York: Routledge, 2006.

. Stokely: A Life. New York: Basic Civitas, 2014.

. Waiting 'Til the Midnight Hour. A Narrative History of Black Power. New York: Holt, 2007.

JUNQUEIRA, Mary A. Estados Unidos. Estado Nacional e Narrativa da Nação (1776-1900). São Paulo: Edusp, 2018.

KARNAL, Leandro; PURDY, Sean; FERNANDES, Luiz Estevam; MORAIS, Marcus Vinícius de. História dos Estados Unidos das origens ao século XX. $3^{\text {a }}$ ed. São Paulo: Contexto, 2016

KELLEN, Leslie (ed.). This Light of Ours. Activist photographers of the Civil Rights Movement. Jackson: University Press of Mississippi, 2011.

KELLEY, Robin D.G. Freedom Dreams. The Black Radical Imagination. Boston: Beacon Press, 2002.

KEYSSAR, Alexander. The Right to Vote. The Contested History of Democracy in the United States. Basic Books, 2000.

KING JR, Martin Luther. Where do We Go from Here: chaos or community? Boston: Beacon Press, 1967.

.; CARSON, Clayborne (org.). A autobiografia de Martin Luther King. Rio de Janeiro: Zahar, 2014.

; CARSON, Clayborne (ed.). A Call to Conscience: The Landmark Speeches of Martin Luther King, Jr. New York: Warner Books, 2001. 
LAWSON, Steven F. Running for Freedom: Civil Rights and Black Politics in America Since 1941. 3a ed. Wiley-Blackwell, 2009.

; PAYNE, Charles. Debating the Civil Rights Movement, 1945-1968. 2. ed. Rowman \& Littlefield Publishers, 2006.

LIMONCIC, Flávio. Os Inventores do New Deal. Estado e sindicatos no combate à Grande Depressão. Civilização Brasileira, 2009.

MARABLE, Manning. Malcolm X: Uma Vida de Reinvenções. Companhia das Letras, 2013.

. Race, Reform, and Rebellion: The Second Reconstruction and Beyond in Black America, 1945-2006. 3. ed. Jackson: University Press of Mississippi, 2007.

MAZRUI, Ali A. (ed.). História Geral da África, VIII: África desde 1935. São Paulo: Cortez Editora, 2011.

MEIER, August; RUDWICK, Elliott. CORE. A Study in the Civil Rights Movement, 1942-1968. New York: Oxford University Press, 1973.

MOORE, Carlos. Pichón: a memoir. Race and Revolution in Castro's Cuba. Chicago: Lawrence Hill Books, 2008.

OGBAR, Jeffrey O.G. Black Power: Radical Politics and African American Identity. Baltimore: The John Hopkins University Press, 2004.

OMI, Michael; WINANT, Howard. Racial formation in the United States. $3^{\mathrm{a}}$ ed. New York and London: Routledge, 2015.

PADMORE, George. Pan-Africanism or Communism? London: Dennis Dobson, 1996.

PARADA, Mauricio; BON MEIHY, Murilo Sebe; MATTOS, Pablo Oliveira de. História da África Contemporânea. Rio de Janeiro: Ed. Puc-Rio : Pallas, 2013.

PAYNE, Charles M. I've Got The Light of Freedom. The Organizing Tradition and the Mississippi Freedom Struggle. 2. ed. Berkeley and Los Angeles: The University of California Press, 2007.

PEREIRA, Amauri M. (ed.); CARMICHAEL, Stokely. O Poder Negro. 2a ed. Belo Horizonte: Nandyala, 2018.

RANSBY, Barbara. Ella Baker and the Black Freedom Movement. A Radical Democratic Vision. Chapel Hill \& London: The University of North Carolina Press, 2003.

RIBEIRO, Djamila. Quem tem medo do feminismo negro? São Paulo: Companhia das Letras, 2018. 
ROSZAK, Theodore. A contracultura: reflexões sobre a sociedade tecnocrática e a oposição juvenil. São Paulo: Vozes, 1972.

ROTH, Philip. Pastoral Americana. Companhia das Letras, 1998.

SAID, Edward. A Questão Palestina. Editora Unesp, 2012.

. Representações do Intelectual: as Conferências de Reith de 1993. Companhia das Letras, 2005.

. Reflexões sobre o exílio e outros ensaios. Companhia das Letras, 2003.

SELF, Robert O. American Babylon. Race and the Struggle for Postwar Oakland. Princeton University Press, 2003.

SHAWKI, Ahmed. Libertação negra e socialismo. Editora Sundermann, 2017.

SITKOFF, Harvard. The Struggle For Black Equality, 1954-1992. New York: Hill and Wang, 1993.

SOUSA, Rodrigo Farias de. A Nova Esquerda Americana: De Port Huron aos Weathermen (1960-1969). Rio de Janeiro: Editora FGV, 2009.

. O nascimento do moderno conservadorismo nos Estados Unidos. Ideologia, liberalismo e raça na National Review, 1955-1968. Edição Kindle. Rio de Janeiro, 2019.

SUGRUE, Thomas. Sweet Land of Liberty. The Forgotten Struggle of Civil Rights in the North. New York: Random House, 2009.

SUNDQUIST, Eric J. Strangers in the Land. Blacks, Jews, Post-Holocaust America. Cambridge: Harvard University Press, 2008.

THEOHARIS, Jeanne; WOODARD, Komozi (orgs.). Freedom North. Black Freedom Struggles outside the South. New York: Palgrave Macmillan, 2003.

VAN DEBURG, William L. New Day in Babylon: The Black Power Movement and American Culture. Chicago: The University of Chicago Press, 1993.

VISENTINI, Paulo F.; RIBEIRO, Luiz D. T.; PEREIRA, Analúcia D. História da África e dos Africanos. 3. ed. Petrópolis: Editora Vozes, 2017.

WARREN, Robert Penn. Who Speaks for the Negro? 2. ed. New Haven and London: Yale University Press, 2014.

WASHINGTON, Booker T. et al. The Negro Problem. A series of articles by representative Afro-American negroes of to-day. New York: James Pott \& Company, 1903.

WILLIAMS, Zachery R. In Search of the Talented Tenth. Howard University Public Intellectuals 
and the Dilemmas of Race, 1926-1970. Columbia: University of Missouri Press, 2009.

X, Malcolm; HALEY, Alex. The Autobiography of Malcolm X. As told to Alex Haley. New York: Ballantine Books, 2015.

; BREITMAN, George (org.). Malcolm X Speaks. Selected Speeches and Statements. New York: Grove Press, 1990.

ZELLNER, Bob; CURRY, Constance. The Wrong Side of Murder Creek: A White Southerner in the Freedom Movement. Edição Kindle. Montgomery: NewSouth Books, 2011.

ZINN, Howard. SNCC: The New Abolitionists. Edição Kindle, 2011.

\section{- Artigos, resenhas e capítulos de livros consultados:}

ANDERSON-BRICKER, Kristin. "Triple Jeopardy": black women and the growth of feminist consciousness in SNCC, 1964-1975. In: SPRINGER, Kimberly (org.). Still lifting, still climbing. African American women's contemporary activism. New York and London: New York University Press, 1999, p. 49-69.

BARKER, Lucius J. Book Reviews. Midwest Journal of Political Science, v. 13, n. 4, nov. 1969, p. 656-661.

BISSIO, Beatriz. A Guerra Fria vista a partir do Sul. Diálogos, v. 22, n. 01, jan./abr. 2018, p. 115-125.

CARMICHAEL, Stokely. Letters from Stokely Carmichael (Kwame Ture). In: NKRUMAH, Kwame; MBALIA, Doreatha D. (org.). Kwame Nkrumah: More letters from the Conakry years. Edição Kindle, 2017.

CASTRO, Fidel. De Martí a Marx. In: LÖWY, Michael (org.). O Marxismo na América Latina: uma antologia de 1909 aos dias atuais. São Paulo: Fundação Perseu Abramo, 1999, p. $265-274$.

CHA-JUA, Sundiata Keita. The New Nadir: The contemporary black racial formation. Black Scholar, v. 40, n. 1, spring 2010, p. 38-58.

CHARTIER, Roger. Do livro à leitura. In: CHARTIER, Roger (org.). Práticas da Leitura. São Paulo: Estação da Liberdade, 2001.

COBB JR., Charles E. From Stokely Carmichael to Kwame Ture. Callaloo, v. 34, n. 01, winter 2011, p. 89-97. 
COOPER, David. Introduction. In: (ed.). The Dialectics of Liberation. London: Verso, 2015.

CURRIE, Elliott; GODDARD, Tim; MYERS, Randolph R. The Dark Ghetto revisited: Kenneth B. Clark's classic analysis as cutting edge criminology. Theoretical criminology, v. 19, n. 1, fev. 2015, p. 5-22.

DU BOIS, W.E.B. The Talented Tenth. In: WASHINGTON, Booker T. et al. The Negro Problem. A series of articles by representative Afro-American negroes of to-day. New York: James Pott \& Company, 1903.

EAGLES, Charles W. Toward New Histories of the Civil Rights Movement. The Journal of Southern History, v. 66, n. 04, nov. 2000, p. 815-848.

FRANCISCO, Flávio Thales Ribeiro. A utopia pós-racial nos Estados Unidos: reestruturação do racismo e a ascensão de Barack Obama na era do colorblindness. Revista de História da UEG, v. 6, n. 1, jan./jul. 2017, p. 01-23.

FRASER, Cary. An American Dilemma: Race and Realpolitik in the American Response to the Bandung Conference, 1955. In: PLUMMER, Brenda Gayle (ed.). Window on Freedom: Race, Civil Rights and Foreign Affairs, 1945-1988. Chapel Hill and London: University of North Carolina Press, 2003. p. 115-140.

GORDON, Lewis R. Prefácio. In: FANON, Frantz. Pele negra, máscaras brancas. Salvador: EDUFBA, 2008, p. 11-17.

GUEVARA, Ernesto Che. Mensagem à Tricontinental. In: LÖWY, Michael (org.). O Marxismo na América Latina: uma antologia de 1909 aos dias atuais. São Paulo: Fundação Perseu Abramo, 1999, p. 285-288.

HALL, Jacquelyn D. The Long Civil Rights Movement and The Political Uses of the Past. The Journal of American History, v. 91, n. 04, mar. 2005, p. 1233-1263.

HALL, Stuart. A formação de um intelectual diaspórico: uma entrevista com Stuart Hall, de Kuan-Hsing Chen. In: HALL, Stuart; SOVIC, Liv (org.). Da Diáspora. Identidades e Mediações Culturais. 2a ed. Belo Horizonte: Editora UFMG, 2018, p. 451-480. . Identidade cultural e diáspora. Revista do Patrimônio Histórico e Artístico Nacional, n. 24, 1996, p. 68-75.

. Pensando a diáspora: reflexões sobre a terra no exterior. In: HALL, Stuart; SOVIC, Liv (org.). Da Diáspora. Identidades e Mediações Culturais. 2a ed. Belo Horizonte: 
Editora UFMG, 2018, p. 27-55.

. Quem precisa da identidade? In: SILVA, Tomaz Tadeu (org. e trad.). Identidade e diferença: a perspectiva dos Estudos Culturais. Petrópolis: Vozes, 2000. p. 103-133.

HAMILTON, Charles V.; HARRIS, Fredrick C. A Conversation with Charles V. Hamilton. Annual Review of Political Science, v. 21, jul. 2017, p. 21-27.

HAYES, Floyd W; KIENE, Francis A. "All Power to the People": The Political Though of Huey P. Newton and The Black Panther Party. In: JONES, Charles E. (Org.). Edição Kindle. The Black Panther Party Reconsidered. Black Classic Press, 1998.

JOSEPH, Peniel E. Black Studies, student activism, and the Black Power Movement. In:

(org.). The Black Power Movement. Rethinking The Civil Rights-Black Power Era. New York: Routledge, 2006.

. Historians and the Black Power Movement. OAH Magazine of History, v. 22, n. 03, jul. 2008, p. 8-15.

. The Black Power Movement: State of the Field. The Journal of American History, v. 96, n. 03, p. 751-776.

KELLEY, Robin D.G. "Roaring from the east": Third World Dreaming. In: . Freedom Dreams. The Black Radical Imagination. Boston: Beacon Press, 2002, p. 60-109.

MARCUSSI, Alexandre Almeida. Personalidade, raça e nação na África pós-colonial: alguns apontamentos a partir das ideias de Kwame Nkrumah. In: REIS, Raissa Brescia dos; RESENDE, Taciana Almeida Garrido de; MOTA, Thiago Henrique (orgs.). Estudos sobre África Ocidental: dinâmicas culturais, diálogos atlânticos. Curitiba: Editora Prismas, 2016, p. 259-285.

MALACCO, Felipe Silveira de Oliveira. Unidade Nacional e Unidade Continental: uma discussão acerca dos projetos políticos de Amílcar Cabral e Kwame Nkrumah. Revista Ars Histórica, n. 17, jul./dez. 2018, p. 78-100.

MINOR, Ethel N. Editor's Preface. In: CARMICHAEL, Stokely. Stokely Speaks: From Black Power to Pan-Africanism. 2. ed. Lawrence Hill Books, 2007, p. XV-XXII.

MUNHOZ, Sidnei. Imperialismo e Anti-imperialismo, Comunismo e Anticomunismo durante a Guerra Fria. Florianópolis: Revista Esboços, v. 23, n. 36, fev. 2017, p. 452-469.

POCOCK, J.G.A. America's Foundations, Foundationalisms, and Fundamentalisms. Orbis, v. 49, n. 01 , jan. 2005 , p. 37-44. 
ROBNETT, Belinda. African-American Women in the Civil Rights Movement, 1954-65: Gender, Leadership, and Micromobilization. American Journal of Sociology, v. 101, n. 6, mai. 1996, p. 1661-1693.

RUSTIN, Bayard. Black Power and Coalition Politics. Commentary, n. 42, set. 1966, p. 35-40.

SEIDMAN, Sarah. Tricontinental routes of solidarity: Stokely Carmichael in Cuba. Journal of Transnational American Studies, v. 4. n. 2, 2012, p. 1-25.

SCHERER, Mathias Inacio. Kwame Nkrumah, o neocolonialismo e o pan-africanismo. In: MACEDO, José Rivair (org.). O Pensamento Africano no Século XX. São Paulo: Outras Expressões, 2016, p. 143-166.

SIRINELLI, Jean-François. Os intelectuais. In: RÉMOND, René (org.). Por Uma História Política. Editora FGV, 2003. p. 231-269.

TURNER, Ralph H. Review. American Journal of Sociology, v. 74, n. 2, set. 1968, p. 197-199.

WENDT, Simon. The roots of Black Power? Armed resistance and the radicalization of the Civil

Rights Movement. In: JOSEPH, Peniel E. (org.). The Black Power Movement. Rethinking the Civil Rights-Black Power Era. New York: Routledge, 2006.

WINSTON, Michael R. Review: Black Power, White Power, and the Negro Intellectual. The Journal of Negro Education, v. 38, n. 2, spring 1969, p. 162-164.

YOUNG, Cynthia. Havana up in Harlem: LeRoy Jones, Harold Cruse and the making of a cultural revolution. Science \& Society, v. 65, n. 01, spring 2001, p. 12-38.

YOUNG, Robert C. Postcolonialism: From Bandung to the Tricontinental. Historien, v. 5, [S.I.], may 2006, p. 11-21.

\section{- Websites/referências consultadas online:}

1. Website do Hilltop Online (Jornal do Campus da Howard University). Link consultado: $<$ http://thehilltoponline.com/2016/05/19/the-hilltop-archives-1961-malcolm-x-at-the-mecca/>. Acesso em: 29 de agosto de 2017.

2. Website de veteranos do Movimento pelos Direitos Civis. Links consultados: $<$ http://www.crmvet.org/images/imgfs.htm>. Acesso em: 28 de agosto de 2017. $<$ http://www.crmvet.org/info/voter_ms.pdf $>$. Acesso em: 30 de agosto de 2017. $<$ http://www.crmvet.org/info/6609_rustin_blkpwr.pdf $>$. Acesso em: 31 de agosto de 2017 
3. Website da Conferência da Dialética da Libertação. Link consultado:

$<$ http://www.dialecticsofliberation.com/1967-dialectics/dialectics-introduction/>. Acesso em: 09 de maio de 2018.

4. Website oficial do AAPRP - All-African Peoples Revolutionary Party. Material consultado: $<$ https://aaprp-intl.org/some-aspects-of-the-aaprp/>. Acesso em: 28 de março de 2018. Overview of Essential aspects of Nkrumahism-Touréism: Ideology of the AAPRP. In: $<$ https://aaprp-intl.org/ideology-of-the-aaprp/>. Acesso em: 28 de março de 2018. $<$ https://aaprp-intl.org/historical-origins-of-the-a-aprp/>. Acesso em: 15 de novembro de 2018.

5. Website do Martin Luther King Jr. Research and Education Institute (Stanford University). Link consultado:

$<$ https://kinginstitute.stanford.edu/encyclopedia/negro-american-labor-council-nalc $>$. Acesso em: 28 outubro de 2018.

6. Website da Penguin Random House. Link consultado: $<$ https://www.penguinrandomhouse.com/about-us/our-story/>. Acesso em: 05 de julho de 2018.

7. Website U.S. Intellectual History Blog.

GREENE II, Robert. “Black Power” and Stokely Carmichael's defining of ideology in 1967. Disponível em: <https://s-usih.org/2013/11/black-power-and-stokely-carmichaels-defining-ofideology-in-1967\#_ftn2>. Acesso em: 31 de julho de 2018.

8. Website Alma Preta - Artigo sobre o Partido dos Panteras Negras:

BORGES, Pedro. Panteras Negras, todo poder ao povo. Disponível em: $<$ https://www.almapreta.com/editorias/realidade/panteras-negras-todo-poder-ao-povo $>$. Acesso em: 12 de agosto de 2018.

9. Website do arquivo digital do The New York Times (Times Machine). Link consultado: $<$ https://timesmachine.nytimes.com/browser>. Materiais consultados:

Editorial. "Black Power". The New York Times, 12 jul. 1966, p. 41.

Editorial. The politics of frustration. The New York Times, 07 ago. 1966, p. 158.

JANSON, Donald. A theorist terms Black Power "clear alternative" to violence. The New York 
Times, 22 jan. 1968, p. 18.

KAUFMAN, Michael T. Stokely Carmichael, rights leader who coined "Black Power", dies at 57. The New York Times, 16 nov. 1998, p. 10.

LESTER, Julius. The End of White World Supremacy. Stokely Speaks. The New York Times, 16 mai. 1971, p. $4 ; 22$.

POWLEDGE, Fred. A Slogan, a Chant, a Threat. The New York Times, 10 dez. 1967, p. 362.

10. Website do arquivo digital The New York Review of Books. Resenha consultada:

LASCH, Christopher. A Special Supplement: The Trouble with Black Power. The New York Review of Books, 29 fev. 1968. Disponível em: $<$ https:/www.nybooks.com/articles/1968/02/29/a-special-supplement-the-trouble-with-blackpower/>. Acesso em: 08 de agosto de 2017.

11. Website do Jornal El País. Entrevista consultada:

BRUM, Eliane. Um negro em eterno exílio. El País, 31 ago. 2015. Disponível em: <https://brasil.elpais.com/brasil/2015/08/31/opinion/1441035388 761260.html>. Acesso em: 01 de abril de 2019.

12. Website do arquivo digital da North Carolina State University Libraries Digital Collections: Rare and Unique Materials. Link consultado:

$<$ https://d.lib.ncsu.edu/collections/catalog/0227527>. Acesso em: 10 de março de 2019.

13. Website Getty Images. Link consultado:

$<$ https://www.gettyimages.com/detail/news-photo/dr-kwame-nkrumah-of-newly-independentghana-ghana-mid-to-news-photo/146126958>. Acesso em: 10 de março de 2019.

$<$ https://www.gettyimages.com/detail/news-photo/stokely-carmichael-attends-an-anti-vietnamwar-rally-at-the-news-photo/631774301>. Acesso em: 10 de março de 2019.

14. Website Kilombagem. Link consultado:

$<$ https://kilombagem.net.br/educacao/biblioteca/stokely-carmichael-1941-1998-de-pantera-negraa-pan-africanista/>. Acesso em: 28 de agosto de 2018.

\section{- Audiovisual}


Ain't Got no, I Got Life. In: SIMONE, Nina. 'Nuf Said!’. New York: RCA Records, 1968. Faixa $8(2 \min 08)$.

Anatomy of Violence. Direção e Produção: Peter Davis. Reino Unido, 1967. (29 min). Disponível em: $<$ https://www.youtube.com/watch?v=a-MwCTctZxE $>$. Acesso em: 10 de maio de 2018.

The Black Power Mixtape, 1967-1975. Direção: Göran Olsson. Produção: Annika Rogell, Joslyn Barnes, Danny Glover e Axel Arnö. Suécia e Estados Unidos: Story AB; Sveriges Television (SVT); Louverture Films, 2011. (1h 40m). Disponível em $<$ https://www.youtube.com/watch?v=6bryh0IFMhg $>$. Acesso em: 10 de agosto de 2018. 